LATVIJAS UNIVERSITĀTES

ŽURNĀLS

JOURNAL

OF THE UNIVERSITY OF LATVIA

Juridiskã

zinātne

Law

ISSN 1691-7677 


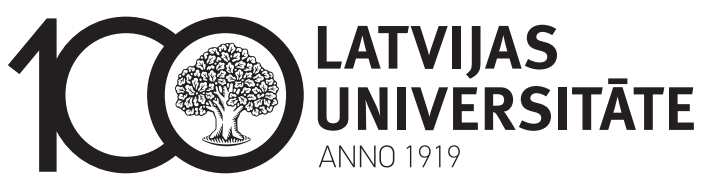

LATVIJAS UNIVERSITĀTES

ŽURNĀLS

NPro 12。

\section{Juridiskā zinātne}

JOURNAL

OF THE UNIVERSITY OF LATVIA

No. 12

Law 
Journal of the University of Latvia "Law" is an open access double blind peer-reviewed scientific journal.

The publishing of Journal of the University of Latvia "Law" is financed by the University of Latvia Faculty of Law.

Publishing of issue No. 12 is supported by Eversheds Sutherland Bitāns Law Office.

\section{EVERSHEDS SUTHERLAND $B I T A \bar{N} S$}

Editor-in-Chief Prof. Jānis Lazdiṇš, University of Latvia

Editorial Board:

Prof. Kaspars Balodis, Latvia

Prof. Ringolds Balodis, Latvia

Assist. Prof. Kamil Baranek, Slovakia

Assist. Prof. Edvīns Danovskis, Latvia

Prof. Heinrich Dörner, Germany

Prof. Aleksandra Dorskaja, Russia

Prof. Michael Geistlinger, Austria

Prof. Helmut Heiss, Switzerland

Prof. Peeter Järvelaid, Estonia

Assoc. Prof. Annija Kārkliņa, Latvia

Assoc. Prof. Jānis Kārkliņšs, Latvia

Assoc. Prof. Artūrs Kučs, Latvia

Prof. Irene Kull, Estonia

Prof. Pia Letto-Vanamo, Finland

Prof. Valentija Liholaja, Latvia

Prof. Hardy Richard Alejandro

Torres López, Chile

Prof. Marju Luts-Sootak, Estonia

Assist. Prof. Vadims Mantrovs, Latvia
Prof. Ārija Meikališa, Latvia

Prof. Sanita Osipova, Latvia

Prof. Peter Oestmann, Germany

Dr. Mārtiņš Paparinskis, United Kingdom

Prof. Lali Papiashvili, Georgia

Assist. Prof. Jānis Pleps, Latvia

Prof. Gerhard Robbers, Germany

Assoc. Prof. Anita Rodin,a, Latvia

Prof. Joachim Rückert, Germany

Prof. Frank L. Schäfer, Germany

Prof. Anna Serebrennikova, Russia

Prof. Mark E. Steiner, USA

Prof. Kristine Strada-Rozenberga, Latvia

Prof. Ditlev Tamm, Denmark

Prof. Kalvis Torgāns, Latvia

Prof. Paul Varul, Estonia

Prof. Aleksandr Vershinin, Russia

Prof. Ingo Saenger, Germany

Prof. Dainius Zalimas, Lithuania

Proofreader Andra Damberga

Layout Andra Liepiņa

No part of the volume may be reproduced in any form without a written permission of the publisher. Journal of the University of Latvia "Law" is included in the international databases EBSCO Publishing and ERIH PLUS. 


\section{Contents}

\section{Sanita Osipova}

Foreword ........................

\section{Kalvis Torgāns}

Contribution of Faculty of Law, University of Latvia, to Science,

State, and Nation . . . . . . . . . . . . . . . .

\section{Irene Kull, Laura Kask}

Electronic Signature Under the eIDAS Regulation in Domestic and Cross-Border Communication: Estonian Example . . . . . . . . . 21

\section{Ārija Meikališa, Kristīne Strada-Rozenberga}

Impact of Directives of European Parliament and of Council on Development of Latvian Criminal Procedure Law: General Overview and Procedural Protection of Victims with Specific

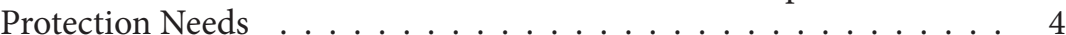

\section{Anna Rytel-Warzocha, Andrzej Szmyt}

Current Constitutional Changes in Poland Against the Background of Polish Political and Legal Traditions . . . . . . . . . . . . . . . 58

\section{Jānis Lazdiňš, Kärlis Ketners}

Avoidance of Double Taxation in the Area of Income Tax in Latvia . . 68

\section{Thomas Schmitz}

Political Parties and Their Funding in Germany . . . . . . . . . . . . . 86

\section{Sanita Osipova}

"The Political Platform of the Latvian People's Council" of 17 November 1918 as the Founder of the Gender Equality Tradition in Latvia Within the Discourse of European Ideas on Gender Equality . . . . . . . . . . . . . . . . . . 


\section{Jautrīte Briede}

Content and Application of Duty of Care Principle in the Field

of Administrative Law in Latvia

\section{Jänis Rozenfelds}

Collateral in Public Register as a Security

of Private Debt . . . . . . . . . . . . . . . . . . . . . . . 122

\section{Kaspars Balodis, Arta Snipe}

Origins of Separated Ownership and Possible Solutions

for Unifying Thereof . . . . . . . . . . . . . . . . . . . . . 139

\section{Silvia Kaugia}

Legislative Intent of Act in Estonia . . . . . . . . . . . . . . . 162

\section{Edvīns Danovskis}

Implementation of the Concept of 'Public Assets'

in the Latvian Legal System . . . . . . . . . . . . . . . . . . . . . . 172

\section{Lauris Rasnačs}

Regimes of Liability for Damages Caused by Abnormally

Dangerous Activities . . . . . . . . . . . . . . . . . . . . 184 


\section{Foreword}

In the University of Latvia, the whole year of 2019 is marked by its centenary. The idea that each nation needed higher education in the national language became vividly pronounced at the end of the $19^{\text {th }}$ century and the beginning of the $20^{\text {th }}$ century. This concept is closely linked to the national awakening of the European people and the following collapse of empires. In the imperial system of education, the possibility to acquire education in languages that were not their official languages was restricted or denied. The young nation states, which themselves, to a large extent, were the embodied dreams held by generations of the national intelligentsia, as one of their first tasks defined the establishment of a national university. This meant severing the ties of intellectual and cultural dependency with the empire and creating a self-sufficient future: to prepare by themselves the specialists needed for the development of fatherland, to develop science, to cultivate own language, which previously had been slighted as being unsuitable for science, proving its full worth and ability to evolve in all spheres of public activities, including all branches of science.

Latvians had been subject to other nations for 700 years, since the $13^{\text {th }}$ century. The national awakening began only following the abolition of serfdom in the Baltic Provinces of the Russian Empire at the beginning of the $19^{\text {th }}$ century. World War I (1914-1918) led to the collapse of the Ottoman, German, Austro-Hungarian and Russian Empires. Like that of many other European nations, the Latvian dream about founding a nation state came true. In 1918, the State of Latvia was established; Latvians became a state nation, and the Latvian language - the official language.

Establishing the national university turned into one of the first tasks for the new state. This meant the possibility to cultivate one's own language, to develop science and prepare academically educated specialists for all fields of economy and culture. At the second sitting of its $3^{\text {rd }}$ session on 15 July 1919, the People's Council of the Republic of Latvia voted for the establishment of a national institution of higher education. The university commenced its work already on 28 September.

The University of Latvia started education of lawyers from the first academic year. Initially, legal science was included in the Faculty of Economics and Law. An independent Faculty of Law was created later, in 1944.

Latvia was occupied by the USSR in 1940. The Republic of Latvia was restored de facto in 1990-1991 on the basis of the doctrine of state continuity. Apart from preparing young lawyers, the Faculty of Law at that moment had the task to facilitate the return of the Latvian legal system to the family of Romano-Germanic law, disposing of the Soviet law legacy. 
This anniversary issue of the journal "Journal of the University of Latvia. Law" is introduced by an article on the contribution given by the Faculty and its members and graduates to the legal science, the nation and the state. It is authored by Professor Kalvis Torgāns, who has linked the greater part of his life (since commencing studies in 1957) with the Faculty of Law of the University of Latvia and, thus, has seen more than 60 years of the hundred years of the Faculty's existence and has been involved in the Faculty's development.

The editorial board of the journal extends its heartfelt greetings to the academician, Professor Kalvis Torgāns on his recently celebrated $80^{\text {th }}$ birthday and expresses gratitude for the positive and encouraging view on the Faculty's achievements. The current issue of our journal proves that scientific research is developing both as to the breadth of topics and the depth of studies. We hope that the published articles will urge both young researchers and veterans to reinforce the prestige of our Faculty as the centre of the Latvian legal science and its significance by providing contemporary solutions to problems.

Dr. iur., Prof. Sanita Osipova

5 April 2019 


\title{
Contribution of Faculty of Law, University of Latvia, to Science, State, and Nation
}

\author{
Dr. habil. iur. Kalvis Torgāns \\ Faculty of Law, University of Latvia \\ Professor, Full Member of the Latvian Academy of Sciences \\ E-mail:kalvis.torgans@lu.lv
}

On the hundredth anniversary of the Faculty of Law, the University of Latvia, a professor, whose life has been linked to this Faculty, provides an overview of its development, contribution to training of specialists in legal professions, to the legal science and consolidation of the rule of law within the state. The article outlines the beginnings of the faculty, dynamics in the number of students, the main lines of research and the most significant publications, the contribution by the faculty members to the drafting of laws, involvement in the work of institutions of state power, administration and law enforcement.

Keywords: legal science, legal education, study programmes, doctors of law, lines of legal research.

\section{Contents}

Introduction ............................. 7

1. Beginnings of the Faculty and Dynamics in Number of Students . . . . . . . . . . . . 9

2. Faculty as the Centre of Legal Education and Science . . . . . . . . . . . . 10

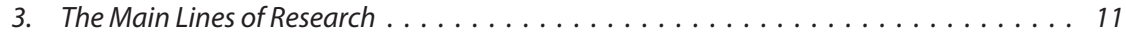

4. Development of Professional Qualification . . . . . . . . . . . . . . . 14

5. Links to Alma Mater Do Not Disappear with Achievements in Practical Work . . . . . . 14

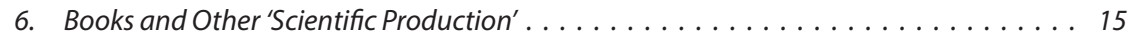

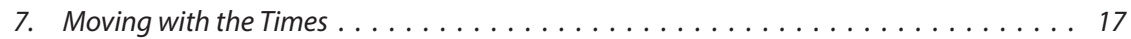

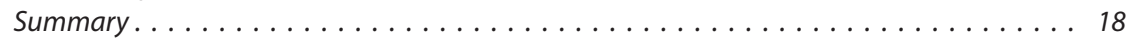

Sources ...................................... 19

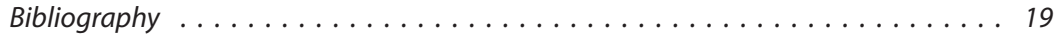

Normative Acts . . . . . . . . . . . . . . . . . . . 20

\section{Introduction}

In 2018, in an elated and optimistic mood, Latvia celebrated the centenary of the existence of its state. The University of Latvia Faculty of Law also celebrates its $100^{\text {th }}$ anniversary in 2019. This is a good reason to look back on the contribution by this centre of legal education and science to the state and society.

The usefulness of an institution can be evaluated by applying a number of criteria. The contribution by the Faculty of Law can be assessed by looking at its 
contribution to educating the nation, as well as at providing the state and society with highly demanded specialists of the legal profession, and also at involvement in drafting and improving the national laws, scientific production, which has promoted the rule of law, public order, and stability in all areas subject to legal regulation.

The author of these lines has been linked to the Faculty since September 1957, when, after successfully passing the entrance exams in a competition with four candidates per one study place, he became a student of the Department of Legal Science of the Faculty of Economics and Law. Later, this Department became an independent faculty. After graduating cum laude from the five-year-long study programme, established at the time, the author spent his entire working life at the university, in differently entitled academic positions, moving from the position of an assistant to those of a senior lecturer, docent, later - professor, has served as the head of a department and a dean. Thus, the author has personally participated in the work of the Faculty of Law for more than sixty years out of the hundred years of the faculty's existence. The writing below should be perceived as eyewitness's observations and assessment, which can be considered a material for scientific research; however, it does not claim to be a comprehensive fragment of the faculty's history, free of subjective impressions.

This treatise could be useful to other researchers, who, in the future, will wish to write a comprehensive book, meeting robust canons of scientific research, about the development of jurisprudence in Latvia, let's say, over 120 or 150 years. At that time, it could be possible to provide a more extensive assessment of the publications by the faculty members of the Faculty of Law, highlighting the most important ones that had changed the tenets of the theory of law and the case law, collect documents regarding their participation in the drafting of laws and turning these into law, recollections about the most brilliant personalities. Undoubtedly, a study of the good deeds and achievements by the Faculty's graduates both at home and in the US, Germany, Australia, Brazil, and elsewhere in the wide world could raise interest. A study of the reasons why part of the graduates has distanced themselves from work in the legal profession and turned to other activities and why the repeatedly predicted overproduction of lawyers has not set in could be less tempting but useful research. A mysterious matter is why many of those who have been on exchange programmes to foreign universities insist that the studies over there are much more intensive and thorough. Such studies would be desirable even without waiting for milestone anniversaries.

Lina Birzina (1910-2007) has contributed significantly to researching the work and publications by the faculty members of the Faculty of Law by collecting and processing information about 29 scholars of the Faculty of Law, supplementing it with recollections of contemporaries for added vividness. ${ }^{1}$ The richly illustrated book $^{2}$, published in 2014, provides an extensive insight into the diverse current activities of the Faculty of Law. However, this is the first description of the Faculty in English, apart from a brochure intended for applicants, published in $1997^{3}$.

1 Birziņa, L. Latvijas Universitātes tiesībzinātnieki. Tiesiskā doma Latvijā XX gadsimtā [Scholars of Law of the University of Latvia. Legal Thinking in Latvia in XX century]. Riga: Zvaigzne ABC, 1999.

2 Latvijas Universitātes Juridiskā fakultāte 1919-2014. Fakti un cilvēki, vēstijumi un fotomirkḷi [The Faculty of Law of the University of Latvia 1919-2014. Facts and People, Messages and Memories in Photos]. Rīga: University of Latvia Press, [s. a.].

3 University of Latvia. Faculty of Law. Riga, 1997. 


\section{Beginnings of the Faculty and Dynamics in Number of Students}

The Faculty of Law commenced its activities in 2019, when a quite small group of law enthusiasts, supported by the state, dared to create an opportunity for inquisitive young people to study jurisprudence at home, decreasing the need to look for study opportunities in the universities of the Russian Empire or Western Europe. At the beginning, the work of the Faculty was ensured by faculty members, who had acquired their legal education in the Universities of Tarbatu (Tartu), Petersburg (Pauls Mincs, Kārlis Dišlers, August Loeber, Vasīlijs Sinaiskis, Benedikts Frēze, Pēteris Lejinšs, and other lawyers, the majority of them born in Latvia) ${ }^{4}$. They shared the aspiration to create academic-level education in Latvia. In the coming years, diligent and energetic graduates of the Faculty - Konstantīns Čakste, Lotārs Šulcs, Jānis Vālbergs, Voldemārs Kalniņšs, and others - rather swiftly joined the community of faculty members.

Later, during the period of Soviet occupation following World War II, the most important contribution to the development of legal science was given by professors Arturs Liede, Marija Blūma, Gustavs Kḷava, Voldemārs Kalniṇš, Oto Grīnbergs, Visvaris Millers, docents Aleksandrs Pavars, Ernests Jostsons, et al.

The book by Romāns Apsītis, Līna Birziṇa and Oto Grīnbergs "History of the State and the Law of the Latvian SSR" (1970), written in the conditions of Soviet occupation and under the influence of the Soviet understanding of law, as well as the book by the same group of authors, published in 2000, "The History of Latvian Law" (1914-2000) provide an insight into the development of legal thinking in the territory of Latvia. During the period of Latvia's independence, prior to the Soviet occupation, the legal culture developed on the basis of the traditions of continental Europe; however, the occupation severed this link and significantly restricted the possibilities of the scholars of law to express genuinely scientific findings.

The number of students, naturally, constantly grew. The number of students enrolled in the study year of 1919/1920 was 39, which, compared to the almost five hundred persons enrolled in 2018 (bachelor's programme - 350, master's programme - 150), seems paltry. However, the foundations were laid in 1919, and development continued.

According to the data, which, perhaps, should be verified, in the period from 1919 to 1944,1721 lawyers graduated from the Faculty ${ }^{5}$. Their further careers have been diverse. In the book about the fate of those lawyers, who graduated before the Faculty was closed during World War II (in 1944), Dietrich André Loeber writes: Dry facts of life conceal most diverse individual fates. A number of them are filled with achievements but often they reveal dramatic and even tragic turns in human lives. Approximately $49 \%$ of the graduates went into exile, $16 \%$ were subjected to repressions during the Soviet regime, $4.5 \%$ became victims of persecutions during the German occupation, and $4.5 \%$ perished on a battlefield. ${ }^{6}$

4 Danovskis, E. Latvijas Universitātes Juridiskās fakultātes vēsture [History of the Faculty of Law of the University of Latvia]. In: Latvijas Universitātes Juridiskā fakultāte 1919-2014. Rīga: University of Latvia Press, 2014, pp. 18-20.

5 Latvijas Universitātes absolventi-juristi 1919-1944. Dzīves un darba gaitas [Graduates-Lawyers of the University of Latvia 1919-1944. The Course of Life and Career]. Rìga, 1999.

6 Lēbers, D. A. Vēstījums par 1721 dzīvesstāstu [Missive of 1721 Life Stories]. In: Latvijas Universitātes absolventi-juristi 1919-1944. Dzīves un darba gaitas. Rìga, 1999, p. 7. 
In the period between the end of World War II and the $60^{\text {th }}$ anniversary of the University (1945-1978), 2633 graduates received the diploma of a lawyer. ${ }^{7}$ Data on the number of graduates during the years of Soviet occupation and in the years following the restoration of independence are incomplete ${ }^{8}$, the graduates' biographies have not been collected. It would be a difficult task to perform, in view of the fact that the number of graduate lawyers was, for example, in the 1970s, approximately 120 annually, whereas in the second half of the 1990s, when day, evening and extra-mural study programmes existed, even more than 500 graduates celebrated their graduation annually, and, with the Faculty's centenary approaching, the number has stabilised at 300 of bachelors and masters graduating annually. It is a significant contribution to increasing the general level of education of the Latvian nation.

\section{Faculty as the Centre of Legal Education and Science}

The scholars of law have significantly contributed to restoring Latvia's statehood after more than 50 years of occupation, firstly, by providing theoretical substantiation and giving concrete proposals to state institutions regarding reinstatement of the state order defined in the Satversme [the Constitution of the Republic of Latvia]; secondly, by actively engaging in drafting and implementing the laws required for the restoration of statehood. Thanks to this, Latvia was admitted to the European Union as a state, the legal system of which, substantially, complied with the circle of Western law. Thirdly, the scholars of law have been constantly seeing to strict observance of law by providing recommendations on how to organise concerted operation of the legislative, executive and the judicial power, how to combat crime, adjudicate fairly administrative and civil law disputes, protect the life, health and property of natural persons, as well as the rights of legal persons. The Legal Aid and Assistance Centre, without seeking acclaim, has been operating since 1999.

When looking from the perspective of a century, it is difficult to characterise the contribution of each particular scholar to legal science, development and consolidation of Latvia's statehood. This task remains for historians to complete. In the period from the establishment of the Faculty until World War II, one of the most important tasks was to create textbooks. At the University, lectures were given both in Russian and Latvian, often using Latin, German and Russian terms. The faculty members gradually turned to developing legal terminology in Latvian. It is noteworthy that the books that were written and published during this period that after the restoration of Latvia's independence were of inestimable significance in reforming the studies of law. To mention a few, the book by Kārlis Dišlers, published in 1938, "Introduction to the Science of Administrative Law", which was published

7 Pētera Stučkas Latvijas Valsts universitātei 60 gadi [60 Years of Peteris Stucka Latvia State University]. Riga: Avots, 1984, p. 13.

8 Latvijas Universitātei 75 [The University of Latvia Turns 75]. Rìga: Latvijas Universitāte, 1994, pp. 467-480; Latvijas Universitātei - 80 [The University of Latvia Turns 80]. Rìga: Latvijas Universitāte, 1999, pp. 238-242; Latvijas Universitāte 1999-2003 [The University of Latvia 1999-2003]. Rìga: University of Latvia Press, 2004. 
repeatedly in $2002^{9}$, Vasilijs Sinaiskis' book on civil law, repeated edition in $1996^{10}$. Until now, one of the most often quoted books, not only in students' papers but also in court judgements, is the textbook on civil procedure by Vladimirs Bukovskis ${ }^{11}$. P. Mincs' book on criminal law also saw a repeated edition ${ }^{12}$. August Loeber's book of 1926 on trade law ${ }^{13}$ was read as a valuable rarity at the time when independent Latvia went through reforms to implement the model of the market economy.

The extensive use of the aforementioned books in Latvia that had regained its independence shows that the fundamental findings of the civilised world have been duly transposed into the study of law. They were further developed by drafting new text books, on the basis of the Satversme of the Republic of Latvia and the new Latvian laws, the compliance of which with the requirements of the age was aligned with the regulatory enactments of the European Union and, at times, contradictory findings taken over from continental Europe and conceptions of the AngloAmerican schools of law.

The Faculty's scholars have done important work in drafting laws and amendments to laws. This work was particularly productive in the initial years following the restoration of Latvia's independence as well as in the years when Latvia was preparing for accession to the European Union. It must be added that over the years the participation of the faculty members in preparing laws has changed. During the initial years following the restoration of Latvia's independence, when principal changes to the legal thinking were required, members of the Saeima and the responsible committees consistently followed the recommendations and proposals given by scholars of law ${ }^{14}$. Slightly later, the members of the parliament started feeling smart enough to draft laws without prolonged consultations. Some draft laws were 'pushed through' without proper analysis. And this led to problems, the solving of which has been taking years, for example, regarding denationalisation and the so-called enforced lease. Since the turn of the century the legislator's cooperation with scholars of law has visibly diminished. This, however, does not mean that science has lost its relevance, in particular, in promoting the understanding of the basic rules of the Satversme.

\section{The Main Lines of Research}

Within the area of legal theory, the integration of the Latvian law in the family of European law, the importance of the constitutional foundations of the Latvian State, the use of legal methods and the course of law development have been studied

9 Dišlers, K. Ievads administratīvo tiesību zinātnē. Administratīvo tiesību kursa vispārīgā daḷa [Introduction to the Science of Administrative Law. The General Part of the Course of Administrative Law]. Rīga: Tiesu namu aǵentūra, 2002.

10 Sinaiskis, V. Latvijas civiltiesību apskats. Lietu tiesības. Saistību tiesības [Overview of the Latvian Civil Law. Rights in Rem. Contract Law]. Rīga: Latvijas Juristu biedrība, 1996.

11 Bukovskis, V. Civīlprocesa mācības grāmata [Textbook of the Civil Procedure]. Rìga: Author's selfpublication, 1933.

12 Mincs, $P$. Krimināltiesību kurss. Vispārējā daḷa [Course of Criminal Law. The General Part]. Rīga: Tiesu namu aǵentūra, 2005.

13 Loebers, A. Tirdzniecības tiesību pārskats [An Overview of the Trade Law]. Rīga: Valters un Rapa, 1926.

14 See Lazdiņš, J. Tendencies in the Development of Laws in the Republic of Latvia after the Renewal of Independence in 1990-1991. Journal of The University of Latvia. Law, No. 8, 2015. Available: https://www.lu.lv/fileadmin/user_upload/lu_portal/apgads/PDF/Jurid-zin-8.pdf [last viewed 13.06.2019]. 
extensively (Edgars Mel̦ķisis, Daiga Rezevska, Jānis Pleps, Jānis Neimanis). Sanita Osipova's work in studying the history of European and Latvian law ("Mirror of the Law of Middle Ages", 2004, "Prehistory of the European Law", 2017) and Jānis Lazdinšs numerous publications in Latvian and German on the legal reforms within the territory of Latvia in the $19^{\text {th }}$ and the $20^{\text {th }}$ centuries are important in the area of legal history studies.

The scholars' contribution to civil law, criminal law and state (administrative) law is embodied in detailed explanations of the main laws in these areas, directing towards correct application of these laws in practice and future improvements. The commentaries on laws reflect the 're-qualification' of the legal science from the Soviet legal doctrine to the achievements of the legal doctrine of democratic Western states, retaining historical peculiarities and traditions. Thus, commentaries on the Civil Law provide not only explanations of the content of the sections of the law in the context of the principles of the market economy regulation but also information on the case law before and after Latvia's occupation, as well as comparison with the laws of Germany, France, and other countries. The commentaries extensively use the contribution by those scholars, who had been involved in drafting the Civil Law and shaped the school of civil law prior to Latvia's occupation, i.e., work of Konstantīns Čakste, Vladimirs Bukovskis, Vasilijs Sinaiskis, Frīdrihs Konradi, and Ādolfs Valters. Hence, critical continuity of civil law theory and conceptions that already existed in Latvia and were suitable for the development of the market economy in conditions of a state that was restoring its independence was ensured. In 2005, the authors of the commentaries were granted the Cabinet's award and honorary diploma for significant contribution to the development of Latvia governed by the rule of law. Commentaries on the Civil Procedure Law (1999-2001) is a fundamental study, which, upon reaching the size of three volumes, has been published repeatedly and in extended editions (2006, 2012 , 2014, 2016). The most important publications on the problems of civil law following the restoration of independence have been prepared by Jānis Vēbers, Jānis Rozenfelds, Kalvis Torgāns, Ilma Čepāne, Kaspars Balodis, Jānis Kārklinš̌, et al.

The scholars of criminal law faced a totally different task. The politicised repressive norms of the Soviet period were deleted from the Criminal Law, the new understanding of the protection of human rights, qualification of criminal offences and penal policy was developed. Uldis Krastiņš and Valentija Liholaja's research ("Comparative Criminal Law. Latvia, Belgium, Denmark, the Netherlands”, 2008) and U. Krastinšs research ("Theory and Practice of Criminal Law: Opinions, Problems and Solutions. 1998-2008" (2009)) significantly influenced the new perspective on the criminal law. Precise application of the criminal procedural norms is important in practice. This has been facilitated by the numerous publications by Ārija Meikališa and Kristīne Strada-Rozenberga; the most important of these are collected in the book "Criminal Procedure. Writings. 2005-2010" (2010) and in a similarly entitled book that was prepared on the occasion of the tenth anniversary of the Criminal Procedure Law in $2015^{15}$.

The work of researchers working in the area of state law (Ringolds Balodis, Anita Rodina, Jautrīte Briede, Annija Kārkliṇa, Edvīns Danovskis, et al.) is aimed at enhancing the foundations of the constitutional order, organisation of public administration, administrative procedure and the rule of law in the functioning

15 Meikališa, A.., Strada-Rozenberga, K. (eds.). Kriminālprocess. Raksti 2010-2915 [Criminal Procedure. Writings 2010-2015]. Rīga: Latvijas Vēstnesis, 2015. 
of the state apparatus. Undeniably, the specialists of state law have contributed to supplementing the Satversme, after the restoration of independence, with Chapter VIII "Fundamental Human Rights" 16 , preparing sizeable scientific commentaries on this new Chapter ${ }^{17}$, as well as adding Introduction (Preamble) to the Satversme in 2014.

Commentaries on the Satversme (on Chapter VIII in 2011, Chapter VI and VII - in 2013, Preamble and Chapter I - in 2014, Chapter III and IV - in 2017, Chapter V - in 2019) have been published. A group of authors under the guidance of scientific editor J. Briede, taking over the tradition of commenting on laws also to the administrative law, has prepared the work "Commentaries on the Administrative Procedure Law. Part A and B" (2013).

International legal relations have become an important part in Latvia's activities in the field of human rights, cross-border family disputes, and, in particular, economic co-operation. Juris Bojārs has examined these matters in several monographs. The issues in exercising and protecting human rights have been researched by Artūrs Kučs, Kristīne Dupate, adding to the contribution by the professor of the Riga Graduate School of Law Ineta Ziemele.

An achievement of international scale was the book in English, published in 2017 by the publishing house "Springer", by the Estonian, Latvian and Lithuanian scholars of law "The Law of Baltic States", which provided the possibility to compare the legal systems of these countries in the EU context. Research projects "Law in the Baltic States. Structure, Problems and Outlook. Latvia. (project manager associate professor A. Rodina), "Trends in applying the general principles of law in the areas of state law, civil law, and criminal law" (manager - professor D. Rezevska), and other projects have been implemented.

Co-operation between scholars of various fields of law has resulted in a sizeable book, created in the framework of the State Research Programme EKOSOC-LV, "Public Law Liability of Legal Persons" (Riga, 2018).

The contribution given by the science of law to society has been noticed and recognised also within the competition between other branches of science. In 2017, the Latvian Academy of Sciences has recognised the importance of a set of Vadims Mantrovs' publications, including a monograph on the EU law on indications of geographical origin: theory and practice (Springer). In 2018, the award named after Professor Dietrich André Loeber (1923-2004) of the Latvian Academy of Sciences was awarded to professor Jānis Lazdiňš - for research of the experience in restoring a rule-of-law and democratic state and outstanding contribution to the development of the Latvian legal science ${ }^{18}$. The highest award of the LAS - the Grand Medal, in turn, was awarded to professor Kalvis Torgāns in 2018 for establishing the contemporary school of civil law and important contribution to the implementation of theoretical findings in practice. ${ }^{19}$

16 Grozijumi Latvijas Republikas Satversmē [Amendments to the Satversme of the Republic of Latvia]. Latvijas Vēstnesis, No. 308/312, 1998.

17 Latvijas Republikas Satversmes komentāri. VIII nodaḷa. Cilvēka pamattiesības [Commentaries on the Satversme of the Republic of Latvia. Chapter VIII. Fundamental Human Rights]. Prepared by a Group of Authors under Scientific Guidance of R. Balodis. Rìga: Latvijas Vēstnesis, 2011.

18 Dïtriha Andreja Lēbera balva - profesoram Jānim Lazdiṇam [Dietrich André Loeber Prize - to Professor Jānis Lazdiňš]. Jurista Vārds, No. 3(1009), 2018.

19 Latvijas Zinātṇu akadēmijas Lielās medaḷas saṇem Vija Zaiga Kluša un Kalvis Torgāns [Vija Zaiga Kluša and Kalvis Torgāns receive the Grand Medals of the Latvian Academy of Sciences]. Zinātnes Vēstnesis, No. 20(562), 2018. 


\section{Development of Professional Qualification}

With the increase in the number of students, the professionalism and the number of faculty members have also grown. At the end of 2018, there were 38 doctors of law, 13 of which were professors, 8 associate professors and 14 docents worked at the Faculty. New addition can be expected from the 36 doctoral students - emerging scientists. This potential allows viewing the Faculty as the leading centre of research and teaching activities in Latvia. The research potential of other institutions of higher education offering study programmes in law, i.e., Turiba University, Riga Stradins University, Riga Graduate School of Law, Riga Technical University, Rezekne Academy of Technologies, and the University of Daugavpils is low for now. Consequently, the Faculty of Law of the University of Latvia contributes the most to ensuring courts, prosecutor's offices, institutions of public administration, the notarial system, the bar and sworn bailiffs with specialists.

A decade ago, defence of the promotional work and acquisition of Dr. iur. title was seen as the outstanding achievements of some individuals and it seemed inconceivable that a third study level, following those of bachelor and master, could appear in the study programme. Currently, the study programme "Legal Science" has become such. For four years the number of doctoral students in the Faculty has been within the range of 35-40. Undeniably, expansion of the doctoral studies, to a certain extent, is contrary to the view that only exceptionally gifted persons are able to acquire the doctoral degree. However, the practice of Europe and of the whole civilised world proves that each branch of science needs this layer of excellent know-how, in the framework of which the further competition for innovative and effective solutions to the problems of the particular field evolves. The potential of the Faculty of Law of the University of Latvia allows taking on the challenge of ensuring on the national and, perhaps, even international level, high-quality doctoral studies in legal science. Notably, during the last six years, 36 young researchers have obtained a doctoral degree from the University of Latvia, and this constitutes 65\% of those who commenced studies. Thus, requirements are sufficiently stringent. Not all doctors of law become lecturers at universities. Thanks to this possibility for improving qualification, the work becomes more effective in institutions of public administration, where the young doctors work, as well as in the bar, the notarial system and other areas of legal work.

\section{Links to Alma Mater Do Not Disappear with Achievements in Practical Work}

Since ancient times, students have been calling their university for the rest of their lives 'the nourishing mother', Alma mater in Latin, and maintained ties with it in various ways.

The graduates recall, with respect and gratitude for introducing to the lawyer's profession, the faculty members. Many graduates remember not only the compendious lectures but also the most vivid statements from seminars and other classes. Time and again, graduate also provide financial support for awarding prizes to the winners of students' contests or for another purpose, even leave inheritance to perpetuate the values of education.

Since the liberalisation of the labour market, which allows taking a number of jobs, it has become hard to establish, which is the main workplace of outstanding graduates of the Faculty and whether the job at the University ranks as the first 
or the second one. Looking at it from the Faculty's perspective, one can say that the faculty members of the Faculty of Law, parallel to their pedagogical and research work, have given and continue to give significant contribution to such state institutions like the Constitutional Court (I. Čepāne, J. Jelagins, S. Osipova, D. Rezevska, K. Balodis, G. Kusiņš), the Saeima (deputies I. Čepāne, I. LỉbinaEgnere, R. Balodis, G. Bērziņš, advisors D. Ose, E. Danovskis), the Supreme Court (U. Krastinnš, I. Fridrihsons, R. Krauze, K. Torgāns, J. Neimanis, J. Briede), the Ministry of Justice (I. Kucina), etc. For four years (2010-2014), the Saeima Legal Affairs Committee, which has a decisive role in preparing all draft laws to be reviewed by the Saeima, was headed by the Faculty's professor Ilma Čepāne (combining jobs) but since the autumn of 2014 until the end of 2018 this work was continued by Gaidis Bērzinšš, who is a lecturer at the Department of Civil Law. It is impossible to name all those, who by their work and personal assiduity have contributed to and reached outstanding success in the life of this state.

One might say that the management of all institutions of the justice system is ensured by the Faculty's graduates. A challenge for the future could be more frequent standing for the positions of and becoming the highest officials of the State, e.g., the Prime Minister and the President of the State, by lawyers. In the hundred years of the State's history, only the first President of the State Jānis Čakste had legal education. In 1993-1994, the Cabinet was headed by the Faculty's graduate Valdis Birkavs. On a more critical note, the number of lawyers in the Saeima (the legislator) is rather low. In 1990, in the Supreme Council of the time, the lawyers took the lead in drafting the Declaration and transferring it for vote, and these lawyers simultaneously were the faculty members of the Faculty of Law, University of Latvia (A. Endziņšs, R. Apsītis, J. Bojārs, A. Plotnieks). The contribution by other lawyers (Tālavs Jundzis, Egils Levits, Valdis Birkavs, et al.) cannot be disregarded. Among the deputies of the Supreme Council who voted for the restoration of Latvia's independence, 15 deputies had graduated from the Faculty of Law, University of Latvia. A number of them gained acknowledged success in enhancing the rule of law in later years, for example, Ilma Čepāne (Briṇke), Tālavs Jundzis, Andris Grūtups, Linards Muciňš, Andris Teikmanis, et al. In the further convocations of the Saeima, the number of deputies with legal education has fluctuated between 12 to 20 from among 100 deputies. For example, in the $10^{\text {th }}$ convocation of the Saeima, there were 18 deputies with legal education and many also - experience in justice. In the $13^{\text {th }}$ convocation of the Saeima, elected in 2018, from among seventeen deputies with legal education ten are the graduates of the Faculty of Law, the University of Latvia.

\section{Books and Other 'Scientific Production'}

The contribution of the Faculty of Law, University of Latvia, is not limited to training of specialists in legal professions. The faculty members with their books, articles in collections of scientific papers, newspapers, as well as participation in public discussions and TV and radio programmes have fostered the understanding of law, amendments to laws, measures taken by the state to enhance the rule of law, among socially active residents of Latvia.

Within the period from the establishment of the Faculty until World War II, one of the most essential tasks was creating textbooks. At the University, lectures were given both in Russian and Latvian, with frequent use of Latin, German and 
Russian terms. The faculty members gradually turned to the development of legal terminology in Latvian. It is noteworthy that, already during this period, books were written and published that were of invaluable importance in reforming legal studies after the restoration of Latvia's independence. Here, the book by Kārlis Dišlers, published in 1938, "Introduction to the Science of Administrative Law", and published repeatedly in $2002^{20}$, must be mentioned, as well as Vasīlijs Sinaiskis' book on civil law, repeated edition in $1996^{21}$. Until now, one of the most frequently quoted books, not only in students' papers but also in court judgements, is the text book on civil procedure by Vladimirs Bukovskis ${ }^{22}$ P. Mincs' book on criminal law also saw a repeated edition ${ }^{23}$. August Loeber's book of 1926 on trade law ${ }^{24}$ was read as a valuable rarity at the time when independent Latvia went through reforms to implement the model of the market economy.

The extensive use of the aforementioned books in Latvia that had regained its independence shows that the fundamental findings of the civilised world have been duly transposed into the study of law. They were further developed by drafting new textbooks, on the basis of the Satversme of the Republic of Latvia and the new Latvian laws, the compliance of which with the requirements of the age was aligned with the regulatory enactments of the European Union and, at times, contradictory findings taken over from continental Europe and conceptions of the AngloAmerican schools of law.

The beginning of the $21^{\text {st }}$ century was characterised by a very active influx of scientific publications, to which the researchers from the Faculty of Law also contributed. With the development of cloud computing of scientific information, bibliographic technologies, use of repositories, citation indexes have become more accessible. Thus, the lists of bibliographical sources, which are found at the end of the three thematic parts on Latvia in the book of 2017 "The Law of the Baltic States" are imperfect, albeit impressive ${ }^{25}$. The majority of works included on the list, covering eleven pages in small print, have been authored by the Faculty's researchers since the beginning of the century.

The accessibility of scientific findings always has been linked with the aim to educate the nation. The first newspaper with legal content was the weekly "Tiesu Vēstnesis" [Courts' Herald] published by Māteru Juris (1880-8, published by J. Māters $)^{26}$. In later publications, the students of the Faculty of Law, the University of Latvia, have been invariably present. During the inter-war period, "Tieslietu Ministrijas Vēstnesis" [Herald of the Ministry of Justice] (1920-40, published by

20 Dišlers, K. Ievads administratīvo tiesību zinātnē. Administratīvo tiesību kursa vispārīgā dalı [Introduction to the Science of Administrative Law. The General Part of the Course of Administrative Law]. Rīga: Tiesu namu aǵentūra, 2002.

21 Sinaiskis, V. Latvijas civiltiesību apskats. Lietu tiesības. Saistību tiesiibas [Overview of the Latvian Civil Law. Rights in Rem. Contract Law]. Rīga: Latvijas Juristu biedrība, 1996.

22 Bukovskis, V. Civīlprocesa mācības grāmata [Textbook of the Civil Procedure]. Rìga: Author's selfpublication, 1933.

23 Mincs, P. Krimināltiesību kurss. Vispārējā daḷa [Course of Criminal Law. The General Part]. Rīga: Tiesu namu aǵentūra, 2005.

24 Loebers, A. Tirdzniecības tiesību pārskats [An Overview of the Trade Law]. Rìga: Valters un Rapa, 1926.

25 The Law of the Baltic States. T. Kerikmäe, K. Joamets, J. Pleps, A. Rodina, T. Berkmanas, E. Gruodyte (eds.). Springer, [s. a.], pp. 187-190, 271-275, 352-355.

26 See Birziņa, L. Latvijas Universitātes tiesībzinātnieki. Tiesiskā doma Latvijā XX gadsimtā [Scholars of Law of the University of Latvia. Legal Thinking in Latvia in XX century]. Riga: Zvaigzne ABC, 1999, p. 14. 
the Ministry of Justice) and "Jurists" [Lawyer] (1928-40, published by association "Aequita"), journal "Rigasche Zeitschrift für Rechtswissenschaft" (1926-39, published by the Riga Association of German Lawyers), journal “Закон и суд” [Law and Court] (1929-38, published by Russian Legal Association). In exile, the lawyer of Latvian origin published journals “Tiesibnieks” [Lawyer] (1947-50, published by Kārlis Vanags, in Germany, refugee camps), "Latviešu Juristu Raksti” [Writings of Latvian Lawyers] (1959-73, published by US Kent Group of Latvian lawyers, in Sweden).

At present, the most significant rostrum for both experienced scholars of law and students is "Jurista Vārds" [Lawyer's Word] (since 1995, published by "Latvijas Vēstnesis"). The University of Latvia Press (since 2010) publishes the journal "Juridiskā zinātne" [Legal Science] and its version in English "Journal of the University of Latvia. Law"). The journal is indexed in the international EBSCO Publishing database. Books by the faculty members are regularly published by the Courthouse Agency, "Latvijas Vēstnesis", sometimes also by the publishing house "Zvaigzne ABC", which was established and is headed by the former honours' student of the Faculty of Law, currently - a successful entrepreneur in publishing Vija Kilbloka.

The volume of the National Encyclopaedia, which is available to all in digital format ${ }^{27}$, is the gift to the nation on the State's centenary. Articles on law by D. Apse, D. Rezevska, J. Pleps, E. Danovskis, V. Liholaja and other faculty members of the Faculty of Law are included in it $^{28}$.

\section{Moving with the Times}

The Faculty keeps growing and changing in accordance with the requirements of the age. The Bologna System $(3+2$ years $)$ has been introduced in study plans, lectures by visiting lectures and student exchange in the framework of ERASMUS+ and Erasmus Mundus programmes have become common. The traditional student surveys have been supplemented with questions regarding the accessibility of computers and the international databases of legal publications. Access to various databases of legal literature has become a routine in the University of Latvia ${ }^{29}$. One might add that the technical progress manifests also as electronic accessibility

27 Nacionālā enciklopēdija [The National Encyclopaedia]. Available: https://enciklopedija.lv/ [last viewed 13.06.2019].

28 Apse, D. Tiesību zinātne [Legal Science]. In: Nacionālā enciklopēdija. Available: https:// enciklopedija.lv/skirklis/7400 [last viewed 13.06.2019]; Danovskis, E. Administratīvās tiesības [Administrative Law]. In: Nacionālā enciklopēdija. Available: https://enciklopedija.lv/skirklis/3141 [last viewed 13.06.2019]; Rezevska, D. Latvijas tiesiskā sistēma [The Latvian Legal System]. In: Nacionālā enciklopēdija. Available: https://enciklopedija.lv/skirklis/25869 [last viewed 13.06.2019]; Pleps, J. Latvijas Valsts prezidenta institūcija [The Institution of the President of the Latvian State]. In: Nacionālā enciklopēdija. Available: https://enciklopedija.lv/skirklis/23220 [last viewed 13.06.2019]; Torgāns, K. Tiesību zinātne Latvijā [Legal Science in Latvia]. In: Nacionālā enciklopēdija. Available: https://enciklopedija.lv/skirklis/9933 [last viewed 19.01.2019].

29 For example, Westlaw UK, Heinonline, OECD iLibrary, Web of Science. Available: https://www. lu.lv/lv/nc/portals/datubazes/ [last viewed 13.06.2019]. 
of many publications, including the articles of scientific conferences held by the Faculty of Law and the journal of the University of Latvia "Juridiskā zinātne"30.

A novelty in the pedagogical work of the Faculty is the Centre of Legal Continuing Education and Professional Improvement, the establishment of which allows expanding the lifelong education of judges, advocates, notaries and representatives of other legal professions.

The University of Latvia keeps rising in various university ratings. In QS Emerging Europe and Central Asia, EECA rating, the University of Latvia for many years has been among the top 50. In 2018, in one of the most prestigious global ratings of universities - Times Higher Education - it was ranked 801 to 1000; moreover, received the highest ranking among the Latvian institutions of higher education $^{31}$. Entry among the first 5 per cent in tough competition allows to set new aims. The Faculty of Law can contribute to reaching them.

\section{Summary}

The establishment of the University of Latvia and formation of the Faculty of Law a hundred years ago held immense social and political significance. It created the possibility for the Latvian youth to obtain higher education at home and, gradually, also in Latvian, which now has been recognised in the Satversme as the only official language. This facilitated the national self-confidence and increase in the legal capacity, the skill to be the master in one's own state and to cooperate with other friendly states developed.

During its hundred years of existence, the Faculty of Law of the University of Latvia has functioned in different frameworks of statehood and political order, both in conditions of an emerging democracy, totalitarianism and a state that has regained its independence and consolidates democracy. All powers need highly educated persons, which can be provided by universities. The Faculty's professors have had to succumb to political campaigns, to some restrictions on academic freedom; however, these could not overwhelm the power of scientific logic, a scholar's conviction. In the conditions of changing powers, the Faculty has maintained faith in the power of science, loyalty to the basic idea of scientific research - to strive for the truth and to pass it on to others. In the vortexes of history, more or less concealed rebelliousness (mutinous spirit?), typical of universities, has always survived, which the hot-blooded youth zealously perceived. Let us not forget history; however, let us perceive it as a sequence of lighter and darker periods in the Faculty's life. The current school of legal science of the Faculty of Law is based on the diverse past experience, which has been critically reviewed and is constantly enriched by the ideas and experience of developed countries, which we gain by integrating into the European legal space. The development of legal thinking, which is manifested in the numerous publications as increasingly

30 For example, Centrālās un Austrumeiropas juridiskās tradīcijas un juridiskās identitātes jautājumi [Legal Traditions and Legal Identities in Central and Eastern Europe]. Collection of research papers of the $76^{\text {th }}$ International Scientific Conference of the University of Latvia. Riga: University of Latvia Press, 2018. Available: https://www.lu.lv/apgads/rakstu-krajumi/juridiskazinatne/ [last viewed 13.06.2019]; Juridiskā zinātne / Law, No. 10, 2017. Available: https://www. journaloftheuniversityoflatvialaw.lu.lv [last viewed 13.06.2019].

31 Latvijas Universitāte “Times Higher Education” reitingā starp Latvijas augstskolām novērtēta visaugstāk [University of Latvia Ranked 801-1000]. Available: https://www.lu.lv/par-mums/lumediji/zinas/arhivs/arhiva-zina/t/44554/ [last viewed 13.06.2019]. 
more extensive and deeper analysis of legal problems, gives faith that the Faculty of Law will be able to contribute significantly to the solution of those problems, which presently occur in the fast-moving contemporary society facing multitude of challenges.

The faculty members, by their books, articles in collections of scientific papers, newspapers, as well as participation in public discussions and TV and radio programmes, have fostered the understanding of law, amendments to laws, measures taken by the state to enhance the rule of law, among socially active residents of Latvia The Faculty marks its hundredth anniversary in full flourish and with an optimistic view of the future.

\section{Sources}

\section{Bibliography}

1. Apse, D. Tiesību zinātne [Legal Science]. Nacionālā enciklopēdija. Available: https://enciklopedija. lv/skirklis/7400 [last viewed 13.06.2019].

2. Birziṇa, L. Latvijas Universitātes tiesībzinātnieki. Tiesiskā doma Latvijā XX gadsimtā [Scholars of Law of the University of Latvia. Legal Thinking in Latvia in XX century]. Riga: Zvaigzne ABC, 1999.

3. Bukovskis, V. Civīlprocesa mācības grāmata [Textbook of the Civil Procedure]. Rīga: Author's selfpublication.

4. Centrālās un Austrumeiropas juridiskās tradīcijas un juridiskās identitātes jautājumi. Legal Traditions and Legal Identities in Central and Eastern Europe. Collection of research papers of the $76^{\text {th }}$ International Scientific Conference of the University of Latvia. Riga: University of Latvia Press, 2018. Available: https://www.lu.lv/apgads/rakstu-krajumi/juridiska-zinatne/ [last viewed 13.06.2019].

5. Danovskis, E. Administratīvās tiesības [Administrative Law]. Nacionālā enciklopēdija. Available: https://enciklopedija.lv/skirklis/3141 [last viewed 13.06.2019].

6. Danovskis, E. Latvijas Universitātes Juridiskās fakultātes vēsture [History of the Faculty of Law of the University of Latvia]. In: Latvijas Universitātes Juridiskā fakultāte 1919-2014. Rīga: University of Latvia Press, 2014, pp. 18-20.

7. Dišlers, K. Ievads administratīvo tiesību zinātnē. Administratīvo tiesību kursa vispārīgā dạ̣a [Introduction to the Science of Administrative Law. The General Part of the Course of Administrative Law]. Rìga: Tiesu namu aǵentūra, 2002.

8. Dītriha Andreja Lēbera balva - profesoram Jānim Lazdiṇam [Dietrich André Prize - to Professor Jānis Lazdiņ̌s]. Jurista Vārds, No. 3(1009), 16.01.2018.

9. Juridiskā zinātne / Law, No. 10, 2017. Available: https://www.journaloftheuniversityoflatvialaw.lu.lv/ [last viewed 13.06.2019].

10. Latvijas Republikas Satversmes komentāri. VIII nodaļa. Cilvēka pamattiesības. [Commentaries on the Satversme of the Republic of Latvia. Chapter VIII. Fundamental Human Rights]. Prepared by a Group of Authors under Scientific Guidance of R. Balodis. Rìga: Latvijas Vēstnesis, 2011.

11. Latvijas Universitāte "Times Higher Education" reitingā starp Latvijas augstskolām novērtēta visaugstāk. University of Latvia Ranked 801-1000. Available: https://www.lu.lv/par-mums/lumediji/zinas/arhivs/arhiva-zina/t/44554/ [last viewed 13.06.2019].

12. Latvijas Universitāte 1999-2003 [The University of Latvia 1999-2003]. Rīga: University of Latvia Press, 2004.

13. Latvijas Universitātei - 80 [The University of Latvia Turns 80]. Rīga: Latvijas Universitāte, 1999, pp. 238-242.

14. Latvijas Universitātei 75 [The University of Latvia Turns 75]. Rīga: Latvijas Universitāte, 1994, pp. $467-480$.

15. Latvijas Universitātes absolventi-juristi 1919-1944. Dzīves un darba gaitas [Graduates-Lawyers of the University of Latvia 1919-1944. The Course of Life and Career]. Rìga, 1999.

16. Latvijas Universitātes Juridiskā fakultāte 1919-2014. Fakti un cilvēki, vēstijumi un fotomirkḷi [The Faculty of Law of the University of Latvia 1919-2014. Facts and People, Messages and Memories in Photos]. Riga: University of Latvia Press, [s. a.].

17. Latvijas Zinātṇu akadēmijas Lielās medaļas saṇem Vija Zaiga Kluša un Kalvis Torgāns [Vija Zaiga Kluša and Kalvis Torgāns receive the Grand Medals of the Latvian Academy of Sciences]. Zinātnes Vèstnesis, No. 20(562), 03.12.2018. 
18. Lazdinš, $J$. Tendencies in the Development of Laws in the Republic of Latvia after the Renewal of Independence in 1990-1991. Journal of The University of Latvia. Law, No. 8, 2015. Available: https:// www.lu.lv/fileadmin/user_upload/lu_portal/apgads/PDF/Jurid-zin-8.pdf [last viewed 13.06.2019].

19. Lēbers, D. A. Vēstījums par 1721 dzīvesstāstu. Latvijas Universitātes absolventi-juristi 1919-1944. Dzives un darba gaitas [Epistle about 1721 Life-stories. Graduates-Lawyers of the University of Latvia 1919-1944. The Course of Life and Career]. Riga, 1999, p. 7.

20. Loebers, A. Tirdzniecības tiesību pārskats [An Overview of the Trade Law]. Rìga: Valters un Rapa, 1926.

21. Meikališa, Ā., Strada-Rozenberga, K. (eds.). Kriminālprocess. Raksti 2010-2015 [Criminal Procedure. Writings 2010-2015]. Rīga: Latvijas Vēstnesis, 2015.

22. Mincs, P. Krimināltiesību kurss. Vispārējā daḷa [Course of Criminal Law. The General Part]. Rīga: Tiesu namu ag̀entūra, 2005.

23. Nacionālā enciklopēdija [National Encyclopaedia]. Available: https://enciklopedija.lv/ [last viewed 13.06.2019].

24. Pētera Stučkas Latvijas Valsts universitātei 60 gadi [60 Years of Peteris Stucka Latvia State University]. Rīga: Avots, 1984, p. 13.

25. Pleps, J. Latvijas Valsts prezidenta institūcija [The Institution of the President of the Latvian State]. Nacionālā enciklopēdija. Available: https://enciklopedija.lv/skirklis/23220 [last viewed 13.06.2019].

26. Rezevska, D. Latvijas tiesiskā sistēma [The Latvian Legal System]. Nacionālā enciklopēdija. Available: https://enciklopedija.lv/skirklis/25869 [last viewed 13.06.2019].

27. Sinaiskis, V. Latvijas civiltiesibu apskats. Lietu tiesibas. Saistibu tiesibas [Overview of the Latvian Civil Law. Rights in Rem. Contract Law]. Rīga: Latvijas Juristu biedrïba, 1996.

28. Sinaiskis, V. Latvijas civiltiesību apskats. Lietu tiesibas. Saistību tiesības [Overview of the Latvian Civil Law. Rights in Rem. Contract Law]. Rīga: Latvijas Juristu biedrïba, 1996.

29. The Law of the Baltic States. T. Kerikmäe, K. Joamets, J. Pleps, A. Rodina, T. Berkmanas, E. Gruodyte (eds.). Springer, [s. a.], pp. 187-190, 271-275, 352-355.

30. Torgāns, K. Tiesību zinātne Latvijā [Legal Science in Latvia]. Nacionālā enciklopēdija. Available: https://enciklopedija.lv/skirklis/9933 [last viewed 19.01.2019].

31. University of Latvia. Faculty of Law. Riga, 1997.

32. Westlaw UK, Heinonline, OECD iLibrary, Web of Science, etc. Available: https://www.lu.lv/lv/nc/ portals/datubazes/ [last viewed 13.06.2019].

\section{Normative Acts}

1. Grozijumi Latvijas Republikas Satversmē [Amendments to the Satversme of the Republic of Latvia]. Latvijas Vēstnesis, No. 308/312, 23.10.1998. 


\title{
Electronic Signature Under the eIDAS Regulation in Domestic and Cross-Border Communication: Estonian Example
}

\author{
Dr. iur. Irene Kull* \\ Faculty of Law, University of Tartu \\ Professor of Civil Law \\ E-mail: irene.kull@ut.ee

\section{Laura Kask} \\ Faculty of Law, University of Tartu \\ PhD Student \\ E-mail:kasklaura1@gmail.com
}

\begin{abstract}
The aim of the article is to analyse issue of cross-border recognition and harmonized rules of electronic signatures under the eIDAS Regulation, which is intended to enable cross border electronic transactions. The authors reveal whether the legal order of the Estonia reflects the changes that have occurred in the field of electronic signatures since eIDAS Regulation. This article examines the legal consequences of a new distinction between the levels of electronic signature in the legal order of a Member State in private transactions and administrative procedures and the conditions under which cross-border recognition of electronic signatures in the European Union takes place.
\end{abstract}

Keywords: digital single market, eIDAS Regulation, electronic signature.

\section{Contents}

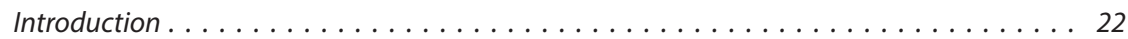

1. Concept of Signature and Formal Requirements of Contracts . . . . . . . . . . . 23

2. Usage of Electronic Signatures in Estonia Before elDAS Regulation . . . . . . . . . . . 26

3. Electronic Signatures in Estonia Since eIDAS Regulation . . . . . . . . . . . . . . . . . 27

4. Regulation of Digital Signature in European Union . . . . . . . . . . . . . . . . . . . . 29

4.1. Historical Introduction . . . . . . . . . . . . . . . . . . . . . 29

4.2. Levels of Electronic Signatures in elDAS Regulation . . . . . . . . . . 30

4.3. Cross-Border Recognition of E-signatures in European Union . . . . . . . . . 31

4.4. Cross-Border Recognition of E-signatures Outside European Union . . . . . . . . 32

5. Levels of E-signatures Used in Practice: Estonian Example . . . . . . . . . . . . . . . . 33

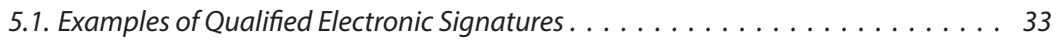

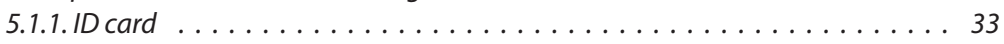

The research led to this article was financed by Estonian Research Council grant PUT PRG 124. 
5.1.2. Mobile ID . . . . . . . . . . . . . . . . . . . . 33

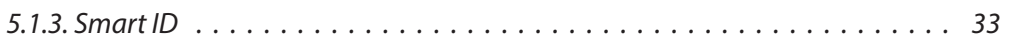

5.2. Examples of Non-Qualified Electronic Signatures . . . . . . . . . . . . . . 34

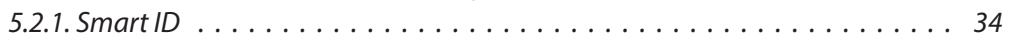

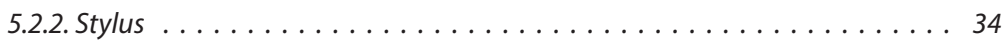

6. Obligation of Service Provider to Provide Information About

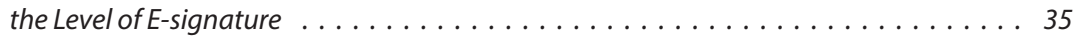

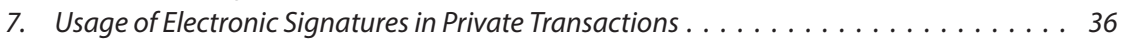

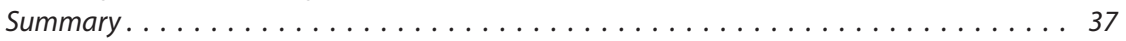

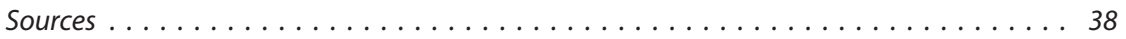

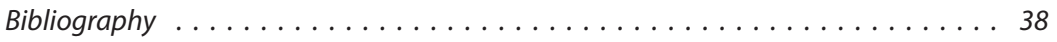

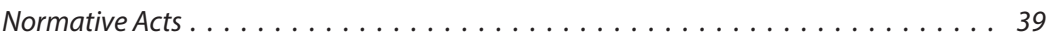

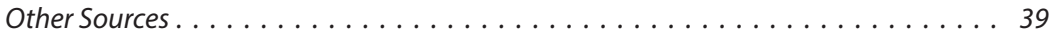

Abbreviations............................ 40

\section{Introduction}

A Digital Single Market is the realm where the free movement of goods, persons, services and capital is ensured and where individuals and businesses can smoothly access and exercise online activities in a fair competition and high level of consumer and personal data protection, irrespective of their nationality or place of residence ${ }^{1}$. The realization of the four fundamental freedoms of the European Union also requires the free movement of data. In an electronic environment, people and services are not transferred, but information is. In order to ensure reliable cross-border communication, it is necessary to identify, by whom and under which conditions the transactions have been made and the contracts concluded. As the digital environment does not recognize national borders and transactions increasingly take place across borders, an interoperable electronic environment is important for the competitiveness of the European Union.

The debate about whether the identification of individuals in the digital environment should be a norm and an obligation, or should the digital environment be a form of expression of our privacy and anonymity, has not disappeared to this day. Although it can be argued that anonymity is an essential part of a democratic cultural concept ${ }^{2}$, the author's assessment should not, however, be oblivious to the fact that in creating a credible digital environment, individuals need to know who with and on what basis they make transactions. This, however, does not restrict the person's freedom to remain anonymous.

The electronic signature that is equal to handwritten signature helps to save time equal to one working week in a year for each working-age adult, ${ }^{3}$ giving time and resources and an appreciable competitive advantage for developed e-states. The ability to identify yourself securely via the internet via an ID card or other e-identity tool or to provide an electronic signature is also available in other EU Member

1 Communication from the Commission to the European Parliament, the Council, the European Economic and Social Committee and the Committee of the Regions. A Digital Single Market Strategy for Europe. 06.05.2015, $\operatorname{COM}(2015) 192$ final. Available: https://eur-lex.europa. eu/legal-content/EN/TXT/?uri=COM\%3A2015\%3A192\%3AFIN [last viewed 30.11.2018].

2 Turk, K. Digitaalkeskkonnas isiku tuvastamise meetmete poolt ja vastu [Pros and Cons of the Measures Used for Identifying Persons in the Digital Environment]. Juridica, No. 3, 2014, p. 176.

3 E-Estonia overview. See more at: https://estonia.ee/overview/ [last viewed 30.11.2018]. 
States (e.g. Latvia, Austria, Finland, Belgium, Spain), but the main means of communication for cross-border services is paper. ${ }^{4}$

Even though in 1999 Directive 1999/93 / EC of the European Parliament and of the Council on a framework for electronic signatures providing for the mutual recognition of signatures ${ }^{5}$ was adopted, electronic cross-border communication in the European Union is still not widely used. This is mainly due to the uneven implementation of the e-signature directive in the Member States, the different technological levels of the countries, the lack of technical interoperability solutions, as well as cultural differences. ${ }^{6}$ eIDAS Regulation of $2014^{7}$ is the next attempt to take cross-border transactions to electronic channels and support the uptake of electronic signatures.

The aim of the article is to analyse the issue of cross-border recognition and harmonized rules of electronic signatures under the eIDAS Regulation, which is intended to enable cross border electronic transactions. As the monopoly of service providers in the field has shifted and the mutual recognition of service providers would mean the consumer has a wider choice of picking the service being used, the national legal orders have to cope with the challenges created by the new levels of electronic signatures. The authors explore, whether the legal order of the Estonia reflects the changes that have occurred in the field of electronic signatures since eIDAS Regulation and how the differentiation of the levels of electronic signatures affect the legislative framework in place. As the legal framework should reflect the practices in place, it is analysed if the Estonian private law needs to be amended or there is no practical challenge and the need might emerge from the court practice. The article does not address the electronic authentication and liability of the service provider and service user.

\section{Concept of Signature and Formal Requirements of Contracts}

In order to analyse the legal meaning of electronic signature and its regulation on national and EU level, it is necessary to agree on the meaning of terms used. Signature can be defined as a handwritten depiction of someone's name, nickname, or even a simple ' $\mathrm{X}$ ' or other mark that a person writes on documents as a proof of identity and intent. ${ }^{8}$ Oxford English Dictionary defines signature as a person's name written in a distinctive way as a form of identification in authorizing a cheque or

4 Varik, H. E-identiteet Eesti ja Euroopa Liidu õigusruumis: Euroopa Parlamendi ja Nõukogu e-identimise ja e-tehingute jaoks vajalike usaldusteenuste määruse kohaldamine Eestis kujunemislugu, probleemid ja eelseisvad väljakutsed [E-Identity in the legal area of Estonia and the European Union: application of the Regulation of Trust Services necessary for e-Identity and e-transactions of the European Parliament and the Council in Estonia - the history of development, problems and impending challenges]. Master thesis. Tallinn, 2015, p. 4.

5 Directive 1999/93/EC of the European Parliament and of the Council of 13 December 1999 on a Community framework for electronic signatures. OJ, L 013, 19.01.2000, pp. 12-20.

6 According to id.ee, there are 1267547 active ID-cards and the population of Estonia is 1,311,800. See more: https://www.stat.ee/ee. Estonian internet users are at the forefront of internet use in Europe in areas like online banking (91\%) and the consumption of news content (91\%). See more at: https:// ec.europa.eu/digital-single-market/en/scoreboard/estonia [last viewed 30.11.2018].

7 Regulation (EU) No. 910/2014 of the European Parliament and of the Council of 23 July 2014 on electronic identification and trust services for electronic transactions in the internal market and repealing Directive 1999/93/EC. OJ, L 257, 28.08.2014, pp. 73-114.

8 The definition from Wikipedia. See more about the meaning of signature at: https://en.wikipedia.org/ wiki/Signature [last viewed 30.11.2018]. 
document or concluding a letter. ${ }^{9}$ DCFR defines person's signature as handwritten signature, electronic signature or advanced electronic signature, and anything being signed by a person (art. I.-1:107(1)) to follow the non-discriminatory approach to any type of signature used in practice for authentication. Estonian legal system does not have legal definition of the concept of 'signature'. ${ }^{10}$ What is more, EU law does not provide definition of a signature while all aspects related to the requirements regarding documents are outside of the scope of harmonization purposes. ${ }^{11}$ Estonian Explanatory Dictionary defines 'signature' as a handwritten name, which is tied to a text, ${ }^{12}$ giving the notion that a signature is something that identifies the person and the text on which it can be found.

While considering the function of written signatures, it is important to distinguish between the concepts of a 'written form' and of a 'handwritten signature'. DCFR art. I.-1:107(2) explains 'handwritten signature' as the name of, or sign representing, a person written by that person's own hand for the purpose of authentication and writing as textual form, on paper or another durable medium an in directly legible characters. ${ }^{13}$ Under Estonian law, the written form means a document which contains a hand-written signature of a person entering the transaction unless otherwise provided by law (\$ 78(1) GPCCA $^{14}$ ). Mechanical signature is also deemed to be equal to handwritten signature, only if mechanical signature is in common usage and the other party does not require a hand-written signature at once ( $\$ 78(2)$ GPCCA). It has to be mentioned that if the contract has to be in written form, written declarations of intention arising from the contract may be communicated also by other means which allow written reproduction of the declarations of intention (\$ 78(3) GPCCA).

Estonia adapted electronic signature as formal requirement of electronic form in 01.07.2002, ${ }^{15}$ although Digital Signatures Act $^{16}$ entered into force already in 2000, setting the formal technical requirements of an electronic signature, but the first digital signature was issued on October 7, 2002. ${ }^{17}$ Before eIDAS Regulation, the legal framework consisted of Digital Signatures Act and GPCCA. According to

9 Oxford English Living Dictionary. Available: https://en.oxforddictionaries.com/definition/signature [last viewed 30.11.2018].

10 For example, US Uniform Commercial Code defines (\$ 1-201(37)) signed as 'using any symbol executed or adopted with present intention to adopt or accept a writing. Writing' includes printing, typewriting, or any other intentional reduction to tangible form'.

11 Directive 1999/93/EC of the European Parliament and of the Council of 13 December 1999 on a Community framework for electronic signatures, art. 1. OJ, L 13, 19.01.2000, pp. 12-20.

12 Eesti keele seletav sõnaraamat [Estonian Explanatory Dictionary]. Available: http://www.eki.ee/ dict/ekss/index.cgi?Q=allkiri\&F=M [last viewed 24.03.2019].

13 For more information see DCFR Annex. Definitions. Principles, Definitions and Model Rules of European Private Law. Draft Common Frame of Reference (DCFR). C. von Bar, E. Clive, H. Schulte-Nölke (eds.). Sellier, European Law Publishers, 2009. Available: https://sakig.pl/uploads/ upfiles/moot/dfcr.pdf [last viewed 30.11.2018].

14 General Part of the Civil Code Act (GPCCA), in force from 01.07.2002. Available in English: https:// www.riigiteataja.ee/en/eli/509012018002/consolide [last viewed 30.11.2018].

15 The requirements were formulated under the harmonisation with the rules of the directive 1999/93/ EU and directive 2000/31/EU (directive on electronic commerce).

16 Digital Signatures Act, in force from 15.12.2000. Available: https://www.riigiteataja.ee/en/eli/ ee/508072014007/consolide [last viewed 30.11.2018].

17 The first contract where digital signature was used was between the mayors of Tallinn (Edgar Savisaar) and Tartu (Andrus Ansip) who signed a Memorandum of Understanding to tighten the cooperation between the cities in the sphere of IT. For more information see: https://sk.ee/uudised/ taitub-aasta-eesti-esimesest-digitaalallkirjast (available in Estonian) [last viewed 30.11.2018]. 
$\$ 80$ of GPCCA, in order to comply with the requirements for the electronic form, a transaction shall be entered into in a form enabling repeated reproduction, contain the names of the persons entering into the transaction and be electronically signed by the persons entering into the transaction. An electronic signature, also digital signature, shall be given in a manner which allows the signature to be associated with the content of the transaction, the person entering into the transaction and the time of entry into the transaction. The procedure for attributing an electronic signature to a person and for giving electronic signatures shall be provided by law ( $\$ 80$ GPCCA). So, digital signatures will primarily be used to prove the identity of a person and higher level of security and are considered to have the same legal consequences as handwritten signatures.

Although the uptake of electronic signatures was not as quick as it was expected, the $10^{\text {th }}$ year of digital signatures celebrated the magical number of 100 million signatures given and it took less than 3 years to achieve 200 million. ${ }^{18}$ Today more than $99.6 \%$ of banking transactions are done online and $99.3 \%$ of people declare taxes online. ${ }^{19}$ This means the electronic channels and electronic signatures have become a commodity in Estonia, although the recent vulnerability case ${ }^{20}$ and security incidents across the world might explain the fear that still exists in legal certainty in comparison to handwritten signatures. What is more, the existing legal regulation still tends to be based on handwritten signatures and paper documents. Therefore, the possibility of a security breach or data leakage might hold back the broader acceptance of electronic signature as the main mean of authorizing transactions in national and cross-border usage.

Although there is no legal definition of a signature, the definition could be taken from the grammatical interpretation and legislator has made the connection between the signature and a person wanting to enter into a transaction in order to prove the will. Electronic signature is legally defined and a certain type of electronic signature is equal to handwritten signature, giving the parties of the transactions and third parties a valid ground to understand the will and the essence of the transaction.

18 For more information and statistics see: https://www.id.ee/?lang=en\&id= [last viewed 30.11.2018].

19 E-Estonian fact sheet. Available: https://e-estonia.com/wp-content/uploads/updated-facts-estonia. pdf [last viewed 30.11.2018].

20 On the evening of 30 August, 2017, a researcher with the Centre for Research on Cryptography and Security at Masaryk University notified Estonia of a security vulnerability (so-called ROCA vulnerability) on the chips used in the Estonian ID card. Over a billion chips were impacted globally, among them those used on Estonian ID cards issued since autumn 2014. Theoretically, the security vulnerability could have allowed the private key (which is used for authentication and signing) to be calculated from the public key - in theory, making it possible to clone the victim's cryptographic keys and use them for authentication, sign or decrypt documents even without being in physical possession of the card. For more information see: https://www.ria.ee/sites/default/files/contenteditors/kuberturve/roca-vulnerability-and-eid-lessons-learned.pdf [last viewed 30.11.2018]. See more about the ROCA vulnerability: ROCA vulnerability and eID: Lessons learned. Information System Authority. Estonian Republic. Available: https://www.ria.ee/sites/default/files/contenteditors/kuberturve/roca-vulnerability-and-eid-lessons-learned.pdf [last viewed 30.11.2018]. 


\section{Usage of Electronic Signatures in Estonia Before eIDAS Regulation}

Estonian private law is based on the principle of freedom of form, declared in the $\$ 77(1)$ GPCCA and $\$ 11(1)$ of the Law of Obligations Act (LOA) ${ }^{21}$. The $\$ 77(1)$ GPCCA provides general rule that a transaction may be entered into in any format unless a mandatory format of the transaction is provided by law, $₫$ 11(1) LOA specifies that the contract may be entered into orally, in writing or in any other form if there are no other required forms provided by law. All requirements concerning different forms are described in the GPCCA. ${ }^{22}$

Every formal requirement has to have a reasonable purpose. For example, handwritten signature is intended to fulfil following functions: to make clear that parties came to the consensus and are intended to be bound by the contract, to warn the parties that by signature they are entering into a binding transaction or to provide an evident in case of dispute. ${ }^{23}$ Electronic signature performs the same functions as handwritten signature since it is not an independent formal requirement, but an option that replaces the requirement of signature written by hand. However, electronic signature is equal to a transaction in written form only as long as it allows the signature to be associated with the content of the transaction, the person entering into the transaction and the time of entry into the transaction (\$ 80(3) GPCCA).

Before eIDAS Regulation, there was only one kind of electronic signature, defined as 'digital signature', which was equal to handwritten signature and regulated by law, namely, Digital Signature Act. The term 'electronic signature' was used in Estonian legal doctrine as general term, e.g., it did not encompass only digital signature. ${ }^{24}$ Nevertheless, there are other possibilities to sign a contract electronically. An example can be drawn with receiving a parcel post, where the acceptance of the parcel is usually done using a stylus. A person is handed a machine where the signature is given with a pencil called stylus and it will create the image of a handwritten signature. However, technically and legally it is not an equivalent of a handwritten signature. There is also a possibility to sign documents by using a fingerprint or an eye retina. Using those methods can be qualified as signing electronically. According to MIT Technology Review, paying with your face, e.g. authorizing transaction with face recognition is among 10 breaktrough technologies in 2017. ${ }^{25}$ The previous and new technologies can be considered as electronic signatures but until they are given the legal validity of electronic signature equal to handwritten signature, they are only considered as a signature in electronic form. As far as law does not provide any mandatory requirements concerning the form of the transaction or signature, the parties can agree on any

21 Law of Obligations Act (LOA), in force from 01.07.2002. Available: https://www.riigiteataja.ee/en/ eli/508082018001/consolide [last viewed 30.11.2018].

22 Estonian GPCCA provides following kind of formal requirements: written form (\$ 78$)$, form which can be reproduced in writing $(\$ 79)$, electronic form $(\$ 80)$, notarial certification of transaction $(\$ 81)$, notarial authentication of transaction $(\$ 82)$.

23 Tsiviilseadustiku üldosa seadus. Kommenteeritud väljaanne [General Part of Civil Code Act. Commented edition]. P. Varul, I. Kull, V. Kõve, M. Käerdi (eds.). Tallinn: Juura, 2010, p. 243.

24 General Part of Civil Code Act. Commented edition (note 22), p. 259. About the use of digital signature before eIDAS Regulation in Internet voting see Madise, Ü., Vinkel, P. Constitutionality of Remote Internet Voting: The Estonian Perspective. Juridica International, No. 18, 2011, pp. 3-16.

25 Knight, W. Paying with your face. MIT Technology Review. Available: https://www. technologyreview.com/s/603494/10-breakthrough-technologies-2017-paying-with-your-face/ [last viewed 30.11.2018]. 
kind of electronic signature, which satisfies their needs and provides required security in respective legal relations.

EIDAS Regulation entered into force in 01.07.2016. An electronic signature remains defined by art. 3(10) of eIDAS Regulation as "data in electronic form which is attached to or logically associated with other data in electronic form and which is used by the signatory to sign". However, there has not been the differentiation of electronic signatures or the concept of levels of electronic signatures in Estonian legal framework. As the functionality of an ID card encompasses the possibility to sign and the signature is technically and legally equal to handwritten signature, there has not been a market of service providers offering different types of electronic signatures. The main problem concerning conclusion of contracts electronically in Estonia might be that the legal framework for accepting anything else than the electronic signature equal to handwritten signature, has been too strict. For example, if the law provides that contract has to be concluded in the form which can be reproduced in writing ( $\$ 79$ GPCCA), the only possibility to sign it electronically has been a digital signature, which corresponds to the qualified e-signature in the eIDAS Regulation. ${ }^{26}$ Digital signature has also been the only possible signature to conclude the contract in electronic form under the $\$ 80$ GPCCA.

In conclusion, Estonian legal system has not differentiated the levels of electronic signatures until July 2016 when the eIDAS regulation became into force. The term used for electronic signature equal to handwritten signature has been 'digital signature' and the term 'qualified electronic signature' is unknown to citizens, but also lawyers and others operating in Estonia and abroad. Nevertheless, it can be stated that the term 'digital signature' can only be used in case of an electronic signature that meets the requirements of a qualified e-signature in the eIDAS Regulation.

\section{Electronic Signatures in Estonia Since eIDAS Regulation}

In order to ensure that the usage of the different levels of electronic signatures regulated under eIDAS Regulation in public and private transactions, the national law must reflect the change of paradigm and facilitate the distinguishing of the levels of electronic signatures. ${ }^{27}$ The existing Estonian regulation imposes conflicts with the eIDAS regulation, as the participants in private relations have too strict requirements, since in order to comply with the electronic form requirements, the electronic signature that is equal to handwritten signature is needed. This means that no lower level signature can be used, although the aims of the signature and electronic form can also be met with lower levels of signature.

In Estonia, the Police and Border Guard Board issues identity documents, and from 2002 the electronic document is issued in addition to the physical document. Identity Document $\mathrm{Act}^{28} \$ 9(5)$ states that the information which enables identification of a person digitally, including a cryptographic key enabling digital identification and the respective certificate, and information which enables digital signing, including a cryptographic key enabling digital signing and the respective

26 eIDAS Regulation, art. 3(12).

27 See more in Dumortier, J. Regulation (EU) No. 910/2014 on Electronic Identification and Trust Services for Electronic Transactions in the Internal Market (eIDAS Regulation) (July 1, 2016). Available at SSRN: https://ssrn.com/abstract=2855484 [last viewed 30.11.2018].

28 Identity Document Act, in force from 01.01.2000. Available: https://www.riigiteataja.ee/en/ eli/526042018001/consolide [last viewed 30.11.2018]. 
certificate, and other digital data may be entered in a document. The functionality of an ID-card allows electronic authentication, gives an opportunity to express declaration of intention by signing documents electronically and allows to encrypt and decrypt the files.

As mentioned before, since the eIDAS Regulation was enforced, the Estonian legislators had to make a choice whether to change the long-rooted term 'digital signature' and transpose the terminology being used in the eIDAS Regulation. The change would have resulted in changing almost all the acts that include interactions with the state, procedural acts, etc. Therefore, the legislator decided to continue to use the terms already employed in legal acts. According to Electronic Identification and Trust Services for Electronic Transactions Act, a digital signature shall be deemed an electronic signature that conforms to the requirements for a qualified electronic signature set out in article 3(12) of eIDAS Regulation. ${ }^{29}$ Consequently, whenever the Estonian legislation uses the term 'digital signature', it means the qualified e-signature.

According to the eIDAS Regulation, a qualified e-signature is an equivalent of a handwritten signature (article 25(2)). This is a general principle, which makes cross-border recognition of signatures legally possible. However, the Member States of the European Union have a margin of discretion in deciding, on the basis of a transaction or proceeding, the formal nature of the electronic transaction in a particular situation. Hence, although in a Member State, under a transaction law, an e-signature can also be signed, it may not be possible in a similar transaction in another Member State, as the legislation requires an electronic signature equivalent to a handwritten signature. Therefore, in spite of the directly applicable regulation, the legislator will decide which of the transactions or procedures and which formality requirements apply.

Although the main service used for electronic signing in Estonia is signing with the state-issued electronic document emitted on the basis of Identity Documents Act, there has been an increase in private sector service usage. It is important for the person to understand the level of the particular e-signature and in which processes and transactions its use is legally and technically possible. The existing Estonian regulation imposes conflicts with the eIDAS regulation, as the participants in private relations have overly strict requirements - in order to comply with the electronic form requirements, the electronic signature that is equal to handwritten signature is needed. The freedom of form gives the parties the ability to agree on a transaction with different levels of electronic signatures, but if there is the electronic form requirement, only electronic signatures that are equal to handwritten signatures can be used. Since, according to the eIDAS Regulation, e-signatures that are in line with the Regulation should be in free circulation in the internal market, Member States have an obligation to support the use of solutions by different service providers.

29 Electronic Identification and Trust Services for Electronic Transactions Act, in force from 12.10.2016. Available: https://www.riigiteataja.ee/en/eli/527102016001/consolide [last viewed 30.11.2018]. 


\section{Regulation of Digital Signature in European Union}

\subsection{Historical Introduction}

On 16 April 1997, the Commission presented to the European Parliament, the Council, the Economic and Social Committee and the Committee of the Regions a Communication on a European Initiative in Electronic Commerce. ${ }^{30}$ The development of digital signatures was mentioned as one of the elements in building trust and confidence among businesses and consumers in use of digital technology. Directive 1999/93/EC of the European Parliament and of the Council of 13 December 1999 on a Community framework for electronic signature was adapted on 19.01.2000 to promote interoperability of electronic-signature products, to facilitate the use of electronic signatures and to contribute to their legal recognition. ${ }^{31}$

Since the e-signature directive did not achieve the desired objective, the European Council recommended in its 4 February and 23 October 2011 conclusions that the European Commission should for 2015 set up an integrated digital single market in key areas for the digital economy to facilitate the cross-border use of Internet-based services. ${ }^{32}$ The considerations of European Commission included the factor that a direct regulation would improve the situation. eIDAS regulation should aim to boost the trust in services in the internal market for e-identity and electronic transactions and is a legal instrument designed to support confidence in electronic transactions in the internal market. The biggest goal of the regulation is to support the foundations of the Digital Single Market. EIDAS Regulation establishes a common basis for secure electronic communication between citizens, businesses and public authorities and increases the efficiency of public-private internet-based services in the European Union. ${ }^{33}$ The regulation should make it easier to use cross-border e-services and help create the same level of trust towards the digital environment as opposed to the physical world, since it sets out common principles for the recognition of electronic identities and e-signatures by European public authorities.

Although the eIDAS Regulation does not cover the procedural rules in national legal order, the legal framework of electronic signatures should be unified across the European Union in order to meet the aims of Digital Single Market Strategy and the eIDAS Regulation. eIDAS Regulation is directly applicable in all $28 \mathrm{EU}$ member states without need of being transposed into local laws. It will replace the overwhelming part of all national signature laws associated to the 1999 Directive. Nevertheless, eIDAS Regulation still leaves areas that can be regulated under domestic law $^{34}$ and the implementation of the eIDAS Regulation depends on national regulation adopting the framework. In Estonia the act implementing the eIDAS Regulation is Electronic Identification and Trust Services for Electronic

30 Electronic Commerce: Commission presents framework for future action. Available: http://europa. eu/rapid/press-release_IP-97-313_en.htm?locale=en [last viewed 30.11.2018].

31 Directive 1999/93/EC of the European Parliament and of the Council of 13 December 1999 on a Community framework for electronic signatures. OJ, L 13, 19.01.2000, pp. 12-20, art. 1(1).

32 eIDAS Regulation, recital 4.

33 eIDAS Regulation, recital 2.

34 In that sense the eIDAS Regulation can be compared to Regulation (EU) 2016/679 of the European Parliament and of the Council of 27 April 2016 on the protection of natural persons with regard to the processing of personal data and on the free movement of such data, and repealing Directive 95/46/EC (General Data Protection Regulation). OJ, L 119, 04.05.2016, pp. 1-88. 
Transactions Act in force from 26.10.2018. ${ }^{35}$ With the entry into force thereof, the Digital Signature Act has become invalid and the new legislative framework consists of eIDAS Regulation and its implementing acts, Electronic Identification and Trust Services for Electronic Transactions Act and its implementing acts.

\subsection{Levels of Electronic Signatures in eIDAS Regulation}

The eIDAS Regulation sets various levels of e-signatures, and e-signature is a general term that covers the various levels of e-signature provided for by the regulation. In accordance with article 3(10) of the eIDAS Regulation, e-signature means electronic data that is attached to, or logically linked to other electronic data and used by the signing authority for the purpose of signing. The eIDAS Regulation distinguishes four levels of e-signatures, which are (1) a qualified e-signature, (2) an advanced e-signature, issued with a qualified certificate, (3) an advanced e-signature, and (4) another e-signature, which does not meet the requirements of the eIDAS Regulation. The Regulation is designed to be tech-neutral and the aim is to support new technologies.

The highest level of e-signature is a qualified e-signature under article 3(12) of the eIDAS Regulation, which is an advanced e-signature, which is provided by a qualified e-signature creation device, based on an e-signature qualified certificate. In order to meet the requirements of the qualified e-signature, the following three conditions must be met: First, the signature must meet the requirements of advanced e-signature. The requirements for advanced e-signature are in accordance with article 26 of the eIDAS Regulation are the following: the e-signature is uniquely linked to the signatory, it is capable of identifying the signatory, it is created using electronic signature creation data that the signatory can, with a high level of confidence, use under his sole control and it is linked to the data signed therewith in such a way that any subsequent change in the data is detectable. Secondly, a qualified electronic signature device must be used when signing. For example, the signature chip must be certified in accordance with article 30 of the eIDAS Regulation. Thirdly, the signature must be based on an e-signature qualified certificate, that is, comply with the requirements of article 28 of the eIDAS Regulation.

The next level of e-signature is an advanced e-signature, that uses a qualified certificate but the difference between the qualified e-signature and advanced e-signature is that the signature creation device is not certified. Other than that, the advanced e-signature meets the same requirements as a qualified e-signature, giving the guarantee that it is possible to identify the relationship between a signed document and a signatory.

The lowest level signature is an advanced e-signature, an e-signature that must comply only with the terms of article 26 of the eIDAS Regulation which means either the certificate nor the device is qualified (has passed a certain audit and meets the certification standards).

An electronic signature that does not meet any of the requirements of the eIDAS Regulation is a so-called other e-signature, which, however, is still permitted in some transactions.

With the entry into fore of eIDAS Regulation, the definitions of e-signatures have become part of Estonian legal system and there is no definition in national

35 Available in English: https://www.riigiteataja.ee/en/eli/527102016001/consolide [last viewed 30.11.2018]. 
law. In Estonian private law, there is the freedom of form and the compulsory requirements for a contract to be valid on the basis of the signature used are only in very specific areas. It's up to the organization to define the level of evidential weight they want to rely on if a document is signed electronically. They may opt to apply e-signatures on a lowest level or can demand the highest level possible which is considered equal to handwritten signature. However, the evidential value of an electronic signature is usually higher and can be controlled more easily than the usage of handwritten signature and the considerations of using the advanced e-signature with a qualified certificate is certainly fulfilling the aims the signature orgininally has. It depends on the risk-assessment and the level of acceptance in the private sector organization, which e-signature is accepted and can be differentiated on the basis of the consequences the transaction is bringing.

\subsection{Cross-Border Recognition of E-signatures in European Union}

Cross-border recognition of signatures is not really a new obligation. The obligation was also laid down in the e-signature directive, which was transposed into Estonian law in accordance with $₫ 40$ of the Digital Signatures Act, which provided that certificates issued by a foreign certification service provider were recognized as equivalent to the certificates issued by the certification service provider operating in Estonia. At least one of the conditions set out in $\$ 40$ of the Digital Signatures Act had to be fulfilled in order to recognise the signature. This still meant that only e-signatures that were meeting the same standards as the digital signatures (qualified e-signatures) were considered equivalent.

According to the eIDAS Regulation, Member States are required to treat all signatures of the same level equally. The legal effects it grants should be achievable by any technical means provided that the requirements of the eIDAS Regulation are met. ${ }^{36}$ As article 25(3) of the eIDAS Regulation stipulates that a qualified electronic signature based on a qualified certificate issued in one Member State shall be recognized as a qualified electronic signature in all other Member States. Article 27 of the eIDAS Regulation states that if a Member State requires an advanced electronic signature to use an online service offered by, or on behalf of, a public sector body, that Member State shall recognized advanced electronic signatures, advanced electronic signatures based on a qualified certificate for electronic signatures, and qualified electronic signatures in at least the formats or using methods defined in the implementing acts meaning that the Estonian public sector is required to accept documents signed using other service providers' solutions that meet the level of e-signature that is allowed to use by national legislation. The Regulation does not enforce private sector to accept the e-signatures from other member states, although the framework and common standards are set and compulsory acceptance by public sector should encourage private sector to follow.

According to article 22(1) of the eIDAS Regulation, each Member State shall establish, maintain and publish trusted lists, including information related to the qualified trust service providers for which it is responsible, together with information related to the qualified trust services provided by them. The Estonian Trusted List is kept by Estonian Technical Regulatory Authority, who also acts as a trust service supervision authority $(\$ 2(3)$ Electronic Identification and Trust Services for Electronic Transactions Act). The trusted lists of the Member States

36 eIDAS Regulation, recital 27. 
are combined into European Union Trust List, ${ }^{37}$ which provides information about who are the qualified service providers operating in the internal market and what services they provide. ${ }^{38}$ Electronic signing is one of the trusted services.

A trusted list has, however, been created for the communication between the computers and allow software to distinguish between applications that are used by the service (whether qualified or not). Implementing acts have been created for the implementation of the eIDAS Regulation, of which the Implementing Act of e-signatures ${ }^{39}$ clearly refers to the standards of the European Telecommunications Standards Institute (ETSI). The e-signatures that are created according the standard, must be accepted and should be understood by the Member States.

However, it must now be acknowledged that the legal framework is in place for the recognition of e-signatures, but the development of technical solutions to address all the different levels of e-signatures that are in use in the European Union is still ongoing at the European Commission and at the national level. In Estonia, the State Information Authority is responsible for developing solutions, which plans to create technical solutions that would allow validation of e-signatures. ${ }^{40}$

Therefore, cross-border recognition of e-signatures is not only a legal obligation, but there is a need to raise awareness that e-signature capabilities that are used in national processes are equally applicable to cross-border communication. In order to understand the level of the e-signature the legal framework is of little use and does not give answers that would be useful for people and businesses using the different levels of e-signatures. It is necessary to create technical solutions to help individuals make informed decisions and understand the legal validity of a document signed by a person using an e-signature service provided by an unknown service provider.

\subsection{Cross-Border Recognition of E-signatures Outside European Union}

Although the digital environment is not country-specific, the regulation on mutual recognition of e-signatures will only apply to the European Union (and the economic area). If, in the past, the possibility for such reciprocal recognition was regulated in accordance with national law and bilateral agreement between the states, then from the entry into force of the eIDAS Regulation, trust services provided by trusted service providers established in a third country in accordance with article 14(1) shall be recognised as legally equivalent to qualified trust services

37 EU Trusted List. Available in XML format: https://ec.europa.eu/information_society/policy/ esignature/trusted-list/tl-mp.xml [last viewed 30.11.2018]. See more about EU Truste List: https://ec.europa.eu/digital-single-market/en/eu-trusted-lists-trust-service-providers [last viewed 30.11.2018].

38 The procedure to be listed in a trusted list is a long procedure and for the purpose and scope of this article it is not analysed further.

39 Commission Implementing Decision (EU) 2015/1506 of 8 September 2015 laying down specifications relating to formats of advanced electronic signatures and advanced seals to be recognised by public sector bodies pursuant to articles 27(5) and 37(5) of Regulation (EU) No. 910/2014 of the European Parliament and of the Council on electronic identification and trust services for electronic transactions in the internal market, article 27(5) and 37(5). OJ, L 235, 09.09.2015, pp 37-41. Available: https://eur-lex.europa.eu/legal-content/EN/TXT/HTML/?uri=CE LEX:32015D1506\&from=ET [last viewed 30.11.2018].

40 Different government officials in State Information Authority have discussed the plans about creating the solutions but up to 01.11.2018 no working solution is yet created for public use. Reimo, T. Allkirjatasemetest rakendustes [Signature levels in applications]. Available in Estonian: https://www.ria.ee/sites/default/files/content-editors/usaldusteenused/usaldusteenused2017tonis_reimo_1.pdf [last viewed 30.11.2018]. 
provided by qualified trust service providers established in the Union where the trust services originating from the third country are recognised under an agreement concluded between the Union and the third country in question or an international organisation in accordance with article 218 TFEU. Thus, for example, it is not possible for Estonia and Georgia to agree on the mutual recognition of e-signatures by a bilateral agreement, but only if the European Union and Georgia would have the relevant agreement. The recognition of third-country e-signatures is likely to require, first of all, the functioning and cooperation of e-signatures on EU level, and then it will be possible to open the single market to e-signatures of countries outside the European Union.

\section{Levels of E-signatures Used in Practice: Estonian Example}

\subsection{Examples of Qualified Electronic Signatures}

\subsubsection{ID card}

The digital signature, i.e. ID card or other documents issued on the basis of the Identity Documents Act (e-residency, digital identity etc), is equivalent to a handwritten signature, as it meets all the requirements for qualified e-signatures, including the qualified signature creation device (i.e. a chip). The electronic functionality of the document can only be used with a special chip reader and have a special software downloaded to your computer.

\subsubsection{Mobile ID}

An electronic authentication and electronic signature can also be done and given with Mobile ID, the certificate for digital identification and the digital signature is issued pursuant to $\$ 20^{4}(1)$ of the Identity Documents Act, and the certificates are associated with a mobile phone SIM card. Using Mobile ID requires a SIM card that supports this solution. The SIM is issued by the telecom operators (Elisa, Tele2, Elion). The chip used for signing with Mobile ID is the qualified signature creation device. This means electronic signature given with Mobile ID is a qualified e-signature and is equal to handwritten signature as it complies with all the requirements for a qualified e-signature in eIDAS Regulation.

\subsubsection{Smart ID}

At the beginning of 2017, Smart ID was launched in Estonia and other Baltic states, which was founded by SK ID Solutions AS and Cybernetica AS. For Smart ID, authentication and electronic signing is created inside the smart gadget (that needs to be connected with WIFI) so that it is easy to use on a smartphone or tablet, without the need for accessories such as a dedicated SIM card or card reader. ${ }^{41}$ The need for the new authentication means supports the implementation timeframe for PSD2 directive, ${ }^{42}$ which sets clear rules for electronic authentication of the bank customers. Smart ID in Estonia was planned to replace parole-cards and other lower level authentication means and create extra layer of security for authorizing transactions. Therefore, it is mostly used in banking systems. Since 8 November

${ }^{41}$ Smart ID. Available: https://sk.ee/en/services/smart-id [last viewed 30.11.2018].

42 Directive (EU) 2015/2366 of the European Parliament and of the Council of 25 November 2015 on payment services in the internal market, amending Directives 2002/65/EC, 2009/110/EC and 2013/36/EU and Regulation (EU) No. 1093/2010, and repealing Directive 2007/64/EC. OJ, L 337, 23.12.2015, pp. 35-127. 
2018 Smart ID is also considered as qualified e-signature creation device meaning the e-signature given with it is equal to handwritten signature.

\subsection{Examples of Non-Qualified Electronic Signatures}

\subsubsection{Smart ID}

Nevertheless, there is still a period between which the e-signatures created by Smart ID were not considered equal to handwritten signatures. After the entry into force of the eIDAS Regulation, each e-signature creation device must undergo a certification process that was not required by service providers before the eIDAS Regulation. This is a procedurally relatively complex process in which the compliance of the service provider with the requirements set out in the regulation (article 24 eIDAS Regulation) and the corresponding audit are checked. In addition, the audit findings (art. 20(1) eIDAS Regulation) must be submitted to the Supervisory Authority every 24 months, at the time of compliance with both the eIDAS Regulation and the relevant standards and the certification of the e-signature instrument (art. 30 eIDAS Regulation). In case of Smart ID, the certification process was finished by November 2018, which means the e-signatures given up to this date or with the certificate that is not renewed, are considered one level lower. In the terms of eIDAS Regulation this is an advanced e-signature with a qualified certificate, but it is not equal to handwritten signature. The signature given to Smart ID will become equivalent to a self-signed signature only after a qualified trust service has undergone a conformity assessment and the service has been entered in the Trusted List. All of the e-signatures that have been given before are advanced e-signatures that are issued using a qualified certificate. This means there is a more complex practice and the situation where only qualified e-signatures that are equal to handwritten signatures has changed.

\subsubsection{Stylus}

One of the possibilities to sign the document is to use touch-sensitive pen or stylus. In that case the signature is given as handwritten signature. Stylus is defined as a computer accessory that is used to assist in navigating or providing more precision when using touchscreens. The most known is the use of stylus upon receipt of parcels. Signature given on the screen by using stylus is similar to a person's signature, the question arises whether this could be treated as handwritten signature equal to the signature on the paper.

In addition to parcel delivery, the image of the signature is used on a driver's license and identity card being an additional security measure that allows for a better checking of identity. In such cases, a signature is issued in the presence of an official or employee who verifies that the signature is provided by the person whose personal data is entered on the document. The signature image given to the screen and then to the document allows the other persons to compare this signature with the signature later on by the person in other cases. The driver's license and identity card also have a person's facial image and date of birth, which is also helpful in checking identity. However, a stylus signature image can be affixed to any document without the person and document having any identifiable link. That is why the signature given on the screen pen cannot be considered equivalent to a self-signed signature. However, this type of signature is appropriate in operations where an electronic signature that is equivalent to a handwritten signature is not required. 


\section{Obligation of Service Provider to Provide Information About the Level of E-signature}

Although the eIDAS Regulation does not affect national rules on, for example, definition of damages, intention, negligence, or relevant applicable procedural rules, customers should be duly informed about the limitations in advance. Those limitations should be recognisable by a third party, for example by including information about the limitations in the terms and conditions of the service provided or through other recognisable means. ${ }^{43}$ It is the duty of the service provider to provide information about the service being offered and art. 13(2) of eIDAS Regulation states that when trust service providers duly inform their customers in advance of the limitations on the use of the services they provide and where those limitations are recognisable to third parties, trust service providers shall not be liable for damages arising from the use of services exceeding the indicated limitations. The limitations should be taken into account with the national rules on liability.

According to Estonian LOA $\$ 48(1) 5)$ a trader shall provide the consumer prior to entry into a contract or making a binding offer by a consumer for this purpose, in the case of digital content, the method of use thereof, the technical protective measures applied to it and compatibility thereof with any hardware and software of which the trader is aware or should be aware. The level of the e-signature is definitely something the person who would like to use the service needs to be aware of. LOA $(\$ 15(2))$ states that if, upon entry into a contract, one party is or should be aware of circumstances which do not constitute a violation of formalities but render the contract void or if such circumstances are caused by the party, the party shall compensate the other party for the damage created due to the fact that the other party believed the contract to be valid.

Smart ID is a service where there is the possibility to create two different levels of e-signatures - advanced e-signature with qualified certificate (from the launch of the service to 07.11.2018 and with the certificates not being renewed) and qualified e-signature with qualified certificate and qualified signature creation device (since 08.11.2018). The terms and conditions of Smart ID describe the level in the terms used by eIDAS Regulation, ${ }^{44}$ but the information is definitely not sufficient for the consumer to enable a person who is not a professional in the field to understand the difference between qualified and non-qualified e-signature. What is more, Estonian legislation uses the term 'digital signature' and the common understanding in the society is that there is only one level of electronic signature and it is equal to handwritten signature. There has not been any court practice yet, but it would be debatable if the service provider is meeting the information requirements and what would be the consequences if the contract is signed using the wrong form of e-signature. Therefore, it would be advisable for the service provider to specify the terms and conditions.

In order to sign the documents with the state- issued electronic certificates (ID card) or with the state-supported electronic certificates (Mobile ID), you need to download a special software. Estonian Information System Authority is responsible

43 eIDAS Regulation. Recital 37.

44 Terms and Conditions for Use of Certificates of Certificates (for qualified Smart ID and nonqualified (advanced) Smart ID). Available: https://www.sk.ee/en/repository/conditions-for-use-ofcertificates/ [last viewed 30.11.2018]. 
for the functioning, development, and management of ID software (the DigiDoc application) designated for the end user. ${ }^{45}$ The software allows to get information about the signed documents and the signatory (person, time, role, validity, etc.). The software gives information whether the e-signature is valid or invalid ('green' or 'red'), including whether it is an equivalent to handwritten signature. It also provides information whether there are any limitations for the usage. For example, if a non-qualified Smart ID is used for a transaction, users are warned that it is an e-signature that can be used for operations that do not require a qualified e-signature or electronic signature equivalent to handwritten signature. However, the software cannot assess all the e-signatures that are used across the EU, and therefore the service providers need to take the responsibility to inform the service users. Nevertheless, the information provided at the moment should redirect users to alternative solutions for identifying the e-signature level and help them to make a more informed decision in accepting or sending the documents being signed electronically.

The differences in technical level and the interoperability across the EU would take time for eIDAS Regulation to be fully implemented. Although forward-looking states like Estonia are offering software that can assess the level of the e-signature without the need of the user to understand the trusted list or the technical nuances behind the different terms and levels of e-signatures. As the eIDAS Regulation is not interfering into the national law in terms of the requirements of information and liability clauses, national law is setting the obligation of the service provider to enclose the details about the service which includes the level of e-signature in a way it would be understandable for a person without expert knowledge. Today the service providers tend to use the terminology of eIDAS Regulation that is not revealing the information about the service.

\section{Usage of Electronic Signatures in Private Transactions}

eIDAS Regulation is not regulating the usage of electronic signatures in private transactions, leaving the national legislation to govern the formal requirements and consequences transactions not meeting the formal requirements. Despite the fact that prior to the entry into force of the eIDAS Regulation, the different levels of signatures in Estonia were not described, the legislator has found that a digital signature is just one form of electronic signature ( $\$$ 80(3) GPCCA), which has also left the possibility to use other e- signatures. Consequently, GPCCA supports the general principles of the eIDAS Regulation, according to which the electronic signature is a general term, and it is possible to take into account the differentiation of levels for the determination of a particular transaction.

However, there is some controversy between $\$ 78$ and $\$ 80$ of the GPCCA because, although it is possible to use lower-level e-signatures in the case of an electronic form, in order to fulfil the written formal requirement, the document must be signed only with a handwritten signature, which in electronic channel would mean with a qualified e-signature (e.g. ID card, Mobile ID, Smart ID since 08.11.2018). Therefore, it could be considered that in the case of a lowerlevel e-signature (e.g. Smart ID until 7.11.2018), the requirement for a written reproduction form are fulfilled, in which, according to $\$ 79$ of the GPCCA, the

45 For more information see: https:/www.ria.ee/en/state-information-system/electronic-identity-eid. html [last viewed 30.11.2018]. 
transaction must be made in a permanent way in a manner allowing the written retransmission and include the names of the persons who made the transaction, but do not need to be signed with a signature equal to handwritten signature.

If there is no special requirement in the law, the transaction may be signed with any level e-signature in order to comply with the requirements of the format capable of reproducing the written reproduction. In the case of a lower-level e-signature, it is necessary to eliminate the contradiction of $\$ 78(1)$ and $\$ 80(1)$ of the GPCCA, which should remain the responsibility of the legislator or the case law, in order to comply with the electronic formality requirement for completeness. Based on the comments GPCCA and the definitions of the eIDAS Regulation, the lower-level signature should also comply with the requirements of the electronic format, but the grammatical interpretation of $\$ 78$ of the GPCCA does not allow it. If a law or agreement requires a handwritten signature or an equivalent electronic signature, it may only be replaced by a qualified electronic signature also meaning a digital signature in Estonian legislation.

In private transactions, failure to comply with the formal requirements set out in law or agreed upon by the parties generally leads to the transaction considered void. The failure to comply with the formal requirement of a transaction being concluded by handwritten signature or the equivalent electronic signature by signing the transaction with a lower level of e-signature is a non-compliance with a formal requirement. However, when deciding on the consequences, the purpose of the formal requirement, the actual will of the parties and the principle of good faith must be taken into account. When using an e-signature of a level different from the agreement of the parties, it is important to take into account the purpose of the formality of the agreement in order to determine the actual will of the parties to decide if the transaction could be deemed void. It would also be important to interpret the behaviour of a person and whether the duties agreed on the basis of the transaction have been executed.

\section{Summary}

Over 650 million digital signatures have been given in Estonia by March 2019. Today, the usage of digital signatures has become a daily routine for the private sector as well as the public sector. Equalizing the processes of the analogue world and the digital environment has laid the foundation for the emergence of an e-state. As a digital single market is a priority of the European Union, the eIDAS Regulation is an important backbone supporting the cross-border usage of online services. The aim of the eIDAS Regulation is to boost trust and convenience in secure and seamless cross-border electronic transactions.

The implementation of the new Regulation is challenging within the Estonian legal framework, as it sets levels for e-signatures which have been unknown in Estonian legislation. It is important to distinguish between the legal consequences of the usage of e-signatures so that individuals could make a conscious and legally binding decision in transactions.

Before eIDAS Regulation the electronic signatures used in Estonia could have been split conditionally into two: digital signatures and other electronic signatures. The eIDAS Regulation sets different levels of signatures and term 'electronic signature' is a general term. It is important to distinguish between the legal consequences of the distinction between the levels of electronic signature so 
that individuals can make a conscious and legally binding decision in transactions, taking into account the formal requirements of the transaction. In Estonian private law, the freedom of form is established as a general principle, with the right to stipulate formal requirements applicable to transactions by law or by agreement of the parties. Therefore, if there is no special requirement in the law, the transaction may be signed with any level of e-signature in order to comply with at least the requirements for a format capable of reproduction in writing. However, if a law or agreement requires a handwritten signature or an equivalent electronic signature, it may only be replaced by a qualified electronic signature or digital signature. However, the authors are of the opinion it would be necessary to amend the law or leave the court practice to decide, whether the lower-level e-signature complies with the requirements of the electronic form. The grammatical interpretation of $\$ 78$ and $\$ 80$ of the GPCCA is not supporting the opinion.

Since the level of e-signature has not been differentiated in Estonian legislation before the entry into force of the eIDAS Regulation, and there is no case law on this issue, the authors consider that if the requirement for a handwritten signature or equivalent electronic form is non-compliant, the court should take into account the current practice and the intention of the parties, the purpose of the formal requirement, the actual will of the parties and the principle of good faith. The authors are not supporting the amendment of law and distinguishing the e-signature levels in private transactions. When an e-signature used is different from the agreement of the parties, it is important to take into account the purpose of the formal agreement in order to determine the actual will of the parties.

In addition to the national legal order, the eIDAS Regulation introduces changes in cross-border communication. Although states can support the uptake by developing software and helping the interoperability, there is the obligation of the service providers to give information about the service, including the level of e-signature. Recognition of cross-border e-signatures is not only subject to a legal obligation, but there is a need to raise awareness, provide correct information and create technological solutions so that electronic means that are in use in national processes can also be used equally in cross-border communication.

\section{Sources}

\section{Bibliography}

1. Bar, C. von, Clive, E., Schulte-Nölke, H. (eds.). Principles, Definitions and Model Rules of European Private Law. Draft Common Frame of Reference (DCFR). Munich: Sellier, 2009.

2. Dumortier, J. Regulation (EU) No. 910/2014 on Electronic Identification and Trust Services for Electronic Transactions in the Internal Market (eIDAS Regulation) (July 1, 2016). Available at SSRN: https://ssrn.com/abstract=2855484 [last viewed 30.11.2018].

3. Erlich, M. E-allkirjad Euroopas ja nende käsitlemine Eestis. Juhend ja nõuanded e-allkirjade käsitlemiseks [E-Signatures in Europe and their treatment in Estonia. Guide and tips for handling e-signatures]. Riigi Infosüsteemi Amet, 2016.

4. Knight, W. Paying with your face. MIT Technology Review. Available: https://www. technologyreview.com/s/603494/10-breakthrough-technologies-2017-paying-with-your-face [last viewed 30.11.2018].

5. Madise, Ü., Vinkel, P. Constitutionality of Remote Internet Voting: The Estonian Perspective. Juridica International, No. 18, 2011.

6. Oxford English Living Dictionary. Available: https://en.oxforddictionaries.com/definition/ [last viewed 30.11.2018].

7. Principles, Definitions and Model Rules of European Private Law. Draft Common Frame of Reference (DCFR). C. von Bar, E. Clive, H. Schulte-Nölke (eds.). Sellier, European Law Publishers, 2009. Available: https://sakig.pl/uploads/upfiles/moot/dfcr.pdf [last viewed 30.11.2018]. 
8. Reimo, T. Allkirjatasemetest rakendustes [Signature levels in applications]. Available in Estonian: https://www.ria.ee/sites/default/files/content-editors/usaldusteenused/usaldusteenused2017tonis_reimo_1.pdfArvutivõrgus [last viewed 30.11.2018].

9. Tsiviilseadustiku üldosa seadus. Kommenteeritud väljaanne [General Part of Civil Code Act. Commented edition]. P. Varul, I. Kull, V. Kõve, M. Käerdi (eds.). Tallinn: Juura, 2010.

10. Turk, K. Digitaalkeskkonnas isiku tuvastamise meetmete poolt ja vastu [Pros and Cons of the Measures Used for Identifying Persons in the Digital Environment]. Juridica, No. 3, 2014.

11. Varik, H. E-identiteet Eesti ja Euroopa Liidu õigusruumis: Euroopa Parlamendi ja Nõukogu e-identimise ja etehingute jaoks vajalike usaldusteenuste määruse kohaldamine Eestis kujunemislugu, probleemid ja eelseisvad väljakutsed. Magistritöö [E-Identity in the legal area of Estonia and the European Union: application of the Regulation of Trust Services necessary for e-Identity and e-transactions of the European Parliament and the Council in Estonia - the history of development, problems and impending challenges]. Master thesis. Tallinn 2015.

\section{Normative Acts}

1. Digital Signatures Act, in force from 15.12.2000. Available: https:/www.riigiteataja.ee/en/eli/ ee/508072014007/consolide [last viewed 30.11.2018].

2. General Part of the Civil Code Act (GPCCA), in force from 01.07.2002. Available in English: https://www.riigiteataja.ee/en/eli/509012018002/consolide [last viewed 30.11.2018].

3. Electronic Identification and Trust Services for Electronic Transactions Act, in force from 12.10.2016. Available: https:/www.riigiteataja.ee/en/eli/527102016001/consolide [last viewed 30.11.2018].

4. Identity Document Act, in force from 01.01.2000. Available: https://www.riigiteataja.ee/en/ eli/526042018001/consolide [last viewed 30.11.2018].

5. Law of Obligations Act (LOA), in force from 01.07.2002. Available: https://www.riigiteataja.ee/en/ eli/508082018001/consolide [last viewed 30.11.2018].

6. Regulation (EU) No. 910/2014 of the European Parliament and of the Council of 23 July 2014 on electronic identification and trust services for electronic transactions in the internal market and repealing Directive 1999/93/EC. OJ, L 257, 28.08.2014, pp. 73-114.

7. Regulation (EU) 2016/679 of the European Parliament and of the Council of 27 April 2016 on the protection of natural persons with regard to the processing of personal data and on the free movement of such data, and repealing Directive 95/46/EC (General Data Protection Regulation). OJ, L 119, 04.05.2016, pp. 1-88.

8. Trust Services for Electronic Transactions Act in force from 26.10.2018. Available: https://www. riigiteataja.ee/en/eli/527102016001/consolide [last viewed 30.11.2018].

\section{Other Sources}

1. Commission Implementing Decision (EU) 2015/1506 of 8 September 2015 laying down specifications relating to formats of advanced electronic signatures and advanced seals to be recognised by public sector bodies pursuant to articles 27(5) and 37(5) of Regulation (EU) No. 910/2014 of the European Parliament and of the Council on electronic identification and trust services for electronic transactions in the internal market. OJ, L 235/37, 09.09.2015.

2. Communication from the Commission to the European Parliament, the Council, the European Economic and Social Committee and the Committee of the Regions. A Digital Single Market Strategy for Europe. 06.05.2015, COM(2015) 192 final.

3. Directive 1999/93/EC of the European Parliament and of the Council of 13 December 1999 on a Community framework for electronic signatures. OJ, L 013, 19.01.2000, pp. 12-20.

4. Directive (EU) 2015/2366 of the European Parliament and of the Council of 25 November 2015 on payment services in the internal market, amending Directives 2002/65/EC, 2009/110/EC and 2013/36/EU and Regulation (EU) No. 1093/2010, and repealing Directive 2007/64/EC. OJ, L 337, 23.12.2015, pp. 35-127.

5. Electronic Commerce: Commission presents framework for future action. Available: http://europa. eu/rapid/press-release_IP-97-313_en.htm?locale=en [last viewed 30.11.2018].

6. EU Trusted List. Available in XML format: https://ec.europa.eu/information_society/policy/ esignature/trusted-list/tl-mp.xml [last viewed 30.11.2018].

7. Smart ID. Available: https://sk.ee/en/services/smart-id [last viewed 30.11.2018].

8. Terms and Conditions for Use of Certificates. Available: https://www.sk.ee/en/repository/ conditions-for-use-of-certificates/ [last viewed 30.11.2018]. 


\section{Abbreviations}

\begin{tabular}{|l|l|}
\hline Art. & Article \\
\hline DCFR & Draft Common Frame of Reference \\
\hline GPCCA & General Part of Civil Code Act (Estonia) \\
\hline eIDAS Regulation & $\begin{array}{l}\text { Regulation (EU) No 910/2014 of the European Parliament and of the Council } \\
\text { of 23 July 2014 on electronic identification and trust services for electronic } \\
\text { transactions in the internal market and repealing Directive 1999/93/EC }\end{array}$ \\
\hline EU & European Union \\
\hline ID Card & identification card \\
\hline LOA & Law of Obligations Act (Estonia) \\
\hline No. & Number \\
\hline Para. & Paragraph \\
\hline ROCA vulnerability & Return of Coppersmith's Attack vulnerability \\
\hline US & United States of America \\
\hline
\end{tabular}




\title{
Impact of Directives of European Parliament and of Council on Development of Latvian Criminal Procedure Law: General Overview and Procedural Protection of Victims with Specific Protection Needs
}

\author{
Dr. iur. Ārija Meikališa \\ University of Latvia, Faculty of Law \\ Professor at the Department of Criminal Law Sciences \\ E-mail:arija.meikalisa@lu.Iv \\ Dr. iur. Kristine Strada-Rozenberga \\ University of Latvia, Faculty of Law \\ Professor at the Department of Criminal Law Sciences \\ E-mail: kristine.strada-rozenberga@/u.Iv
}

The article is dedicated to the impact of the EU law on development of Latvian criminal procedural law norms. It provides a general insight into importance of the EU criminal procedure law in the development of the Criminal Procedure Law norms, the directives of the European Council and the Parliament, the norms of which have been transposed into the Criminal Procedure Law, and the system of procedural guarantees for the participants of proceedings in need of protection, with particular focus on victims with specific protection needs.

Keywords: criminal procedure, directives of the European Parliament and of the Council, procedural guarantees, victims with specific protection needs.

\section{Content}

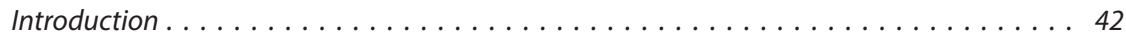

1. General Characteristics of Development of Criminal Procedure Law and Implementation of Directives of the European Council and Parliament as One of the Reasons Substantiating Amendments to Criminal Procedure Law . . . . . 42

2. General Characteristics of Impact of EU Directives on Content

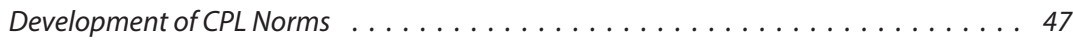

3. Victims with Specific Protection Needs and Reinforcing Protection of Their Interests . . . . . . . . . . . . . . . . . . . . . . . 49

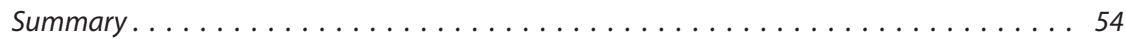

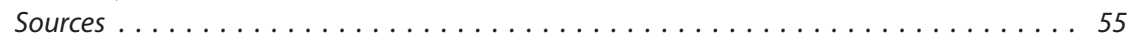

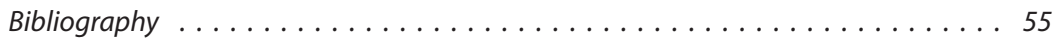

Normative Acts . . . . . . . . . . . . . . . . . . . . . . 56 


\section{Introduction}

The year 2005, when the Criminal Procedure Law ${ }^{1}$ (hereinafter - CPL) was adopted and entered into force, marked a new page in the development of the criminal procedure law in Latvia. It ended a long and complicated period characterised by working on a new criminal procedural legal regulation. However, the hope to succeed in drafting a law that would be stable and remain, at least for some time, without substantive amendments, did not come true, and CPL has become one of the most frequently amended laws in Latvia. There have been various causes for these amendments. One of the most important among these transposition of the norms of the Directives of the European Council and the Parliament (hereinafter - the EU Directives). This circumstance has been the basis for introducing substantial amendments to the Part of CPL on the international criminal procedural cooperation, as well as to the CPL norms dedicated to the occurrences in Latvia or the so-called local criminal proceedings. The aim of this article is to reveal, whether and, if yes, then how the EU Directives have influenced the content of CPL norms, focusing, in particular, on the need to identify the participants of proceedings with specific protection needs and the legal regulation on their procedural guarantees. To this end, an objective has been set to identify those EU Directives, the norms of which have been included in the text of CPL, briefly characterise the terms of transposition thereof, identify the thematic lines of the criminal procedural legal regulation, which have been impacted the most by the transposition of the EU Directives, as well as to examine the compliance of these lines - the establishment of the system of procedural guarantees for the participants of criminal proceedings with specific protection needs in Latvia - with the provisions of the EU Directives. For this purpose, the texts of the regulatory sources - the EU Directives and the Latvian laws - have been analysed in depth; likewise, the available literature sources on the development of the Latvian criminal procedure law have been used.

\section{General Characteristics of Development of Criminal Procedure Law and Implementation of Directives of the European Council and Parliament as One of the Reasons Substantiating Amendments to Criminal Procedure Law}

CPL, which is force in Latvia since 1 October 2005, is one of those laws, which, as mentioned above, has been subject to frequent and sizeable amendments. Within fourteen years followings its adoption, the Latvian Parliament (the Saeima) has adopted 35 laws on introducing amendments to CPL. There have been different reasons for these amendments, which have been identified in literature already a couple of years and have remained unchanged, inter alia 1) implementation of the EU norms, 2) rectifying inaccuracies and shortcomings, 3) responding to relevant issues identified in the practice of applying the $\mathrm{law}^{2}$, to which, in the recent years, could be added the need to enforce the judgements of the Latvian Constitutional

1 Kriminālprocesa likums [Criminal Procedure Law] (21.04.2005). Consolidated version available in Latvian: https://likumi.lv/doc.php?id=107820, in English: https://likumi.lv/ta/en/en/id/107820 [last viewed 10.04.2018].

2 See for example Meikališa, Ā. Kriminālprocesa likumam 10 - fakti, vērtējumi, prognozes [The $10^{\text {th }}$ Anniversary of the Criminal Procedure Law - Facts, Assessments, Forecasts]. In: Meikališa, $\bar{A}$., Strada-Rozenberga, K. Kriminālprocess. Raksti 2010-2015. Rīga: Latvijas Vēstnesis, 2015, p. 142. 
Court, which has ruled on the incompatibility of CPL norms with the Satversme [the Constitution of the Republic of Latvia], as well as following general trends of development (for example, transition to e-addresses, which must be reflect also in the procedural laws, or implementing the law policy position on simplifying, speeding up and intensifying criminal proceedings).

The impact of the EU criminal procedure law on the Latvian national criminal procedure law in the recent decade and even slightly before that no longer can be denied. The amendments to the norms of the Latvian CPL have appeared both by introducing the positions of the EU frameworks decisions and, later, - the norms of the Directives. The norms of the $11^{\text {th }}$ Framework Decision were transposed into CPL by adopting six laws on introducing amendments to $\mathrm{CPL}^{3}$. The norms of 12 Directives, in turn, were transposed by eight laws on introducing amendments. Hence, at least 14 of 35 laws on amendments to CPL were influenced by the EU norms. However, it must be noted that in all these 14 laws decisions were made simultaneously on amending CPL also due to other reasons. Nevertheless, the share of amendments to CPL influenced by the EU norms generally is not the largest but takes an important place. For example, it must be noted that the impact of the EU norms has varied with respect to different parts of CPL. Hence, the transposition of the EU norms clearly has been the reason for introducing amendments to Part $\mathrm{C}$ of CPL dedicated to international cooperation in criminal cases, whereas with respect to Part A (General Provisions) and Part B (Pre-trial Criminal procedure and Court Proceedings in Criminal Cases), which basically apply to the criminal proceedings taking place in Latvia, the share of amendments to the Criminal Procedure Law influenced by the EU law is not the largest but nevertheless takes a sufficiently significant place.

Focusing particularly on the impact of Directives on the development of CPL, which obviously characterises the development of the EU criminal procedural law of the recent years, it must be noted that, currently, legal norms that follow from $12 \mathrm{EU}$ Directives have been included in CPL, and these are as follows:

1) Directive 2010/64/EU of the European Parliament and of the Council of 20 October 2010 on the right to interpretation and translation in criminal proceedings ${ }^{4}$

2) Directive 2011/36/EU of the European Parliament and of the Council of 5 April 2011 on preventing and combating trafficking in human beings and protecting its victims, and replacing council framework decision 2002/629/JHA

3) Directive 2012/13/EU of the European Parliament and of the Council of 22 May 2012 on the right to information in criminal proceedings ${ }^{6}$;

See for more details in: Meikališa, Ā., Strada-Rozenberga, K. Kriminālprocess. Raksti 2010-2015. [Criminal Procedure. Writings 2010-2015]. Rīga: Latvijas Vēstnesis, 2015, pp. 143-144.

4 Directive 2010/64/EU of the European Parliament and of the Council of 20 October 2010 on the right to interpretation and translation in criminal proceedings. OJ, L 280, 26.10.2010, p. 1/7. Available: https://eur-lex.europa.eu/legal-content/EN/TXT/?uri=CELEX:32010L0064 [last viewed 10.04.2018].

5 Directive 2011/36/EU of the European Parliament and of the Council of 5 April 2011 on preventing and combating trafficking in human beings and protecting its victims, and replacing council framework decision 2002/629/JHA. OJ, L 101, 15.04.2011, p. 1/11. Available: https://eur-lex.europa. eu/legal-content/EN/TXT/?uri=CELEX:32011L0036 [last viewed 10.04.2018].

6 Directive 2012/13/EU of the European Parliament and of the Council of 22 May 2012 on the right to information in criminal proceedings. OJ, L 142, 01.06.2012, p. 1/10. Available: https://eur-lex. europa.eu/legal-content/EN/ALL/?uri=CELEX:32012L0013 [last viewed 10.04.2018]. 
4) Directive 2011/92/EU of the European Parliament and of the Council of 13 December 2011 on combating the sexual abuse and sexual exploitation of children and child pornography, and replacing Council Framework Decision 2004/68/JHA ${ }^{7}$;

5) Directive 2011/99/EU of the European Parliament and of the Council of 13 December 2011 on the European protection order $^{8}$;

6) Directive 2012/29/EU of the European Parliament and of the Council of 25 October 2012 establishing minimum standards on the rights, support and protection of victims of crime, and replacing Council Framework Decision 2001/220/JHA ${ }^{9}$;

7) Directive 2013/48/EU of the European Parliament and of the Council of 22 October 2013 on the right of access to a lawyer in criminal proceedings and in European arrest warrant proceedings, and on the right to have a third party informed upon deprivation of liberty and to communicate with third persons and with consular authorities while deprived of liberty ${ }^{10}$;

8) Directive 2014/41/EU of the European Parliament and of the Council of 3 April 2014 regarding the European Investigation Order in criminal matters ${ }^{11}$;

9) Directive 2014/42/EU of the European Parliament and of the Council of 3 April 2014 on the freezing and confiscation of instrumentalities and proceeds of crime in the European Union ${ }^{12}$;

10) Directive (EU) 2016/343 of the European Parliament and of the Council of 9 March 2016 on the strengthening of certain aspects of the presumption of innocence and of the right to be present at the trial in criminal proceedings ${ }^{13}$;

Directive 2011/92/EU of the European Parliament and of the Council of 13 December 2011 on combating the sexual abuse and sexual exploitation of children and child pornography, and replacing Council Framework Decision 2004/68/JHA. OJ, L 335, 17.12.2011, p. 1/14. Consolidated version available: https://eur-lex.europa.eu/legal-content/EN/TXT/?uri=CELEX:02011L009320111217 [last viewed 10.04.2018].

8 Directive 2011/99/EU of the European Parliament and of the Council of 13 December 2011 on the European protection order. OV, L 338, 21.12.2011, p. 2/18. Available: https://eur-lex.europa.eu/ legal-content/EN/TXT/?uri=CELEX:32011L0099 [last viewed 10.04.2018].

9 Directive 2012/29/EU of the European Parliament and of the Council of 25 October 2012 establishing minimum standards on the rights, support and protection of victims of crime, and replacing Council Framework Decision 2001/220/JHA. OJ, L 315, 14.11.2012, p. 57/73. Available: https://eur-lex.europa.eu/legal-content/EN/ALL/?uri=CELEX:32012L0029 [last viewed 10.04.2018].

10 Directive 2013/48/EU of the European Parliament and of the Council of 22 October 2013 on the right of access to a lawyer in criminal proceedings and in European arrest warrant proceedings, and on the right to have a third party informed upon deprivation of liberty and to communicate with third persons and with consular authorities while deprived of liberty. OJ, L 294, 06.11.2013. Available: https://eur-lex.europa.eu/legal-content/EN/TXT/?uri=CELEX:32013L0048 [last viewed 10.04.2018].

11 Directive 2014/41/EU of the European Parliament and of the Council of 3 April 2014 regarding the European Investigation Order in criminal matters. OJ, L 130, 01.05.2014, pp. 1/36. Consolidated version available: https://eur-lex.europa.eu/legal-content/LV/TXT/?uri=CELEX:020 14L0041-20140501 [last viewed 10.04.2018].

12 Directive 2014/42/EU of the European Parliament and of the Council of 3 April 2014 on the freezing and confiscation of instrumentalities and proceeds of crime in the European Union. OJ, L 127, 29.04.2014, pp. 39/50. Consolidated version available: https://eur-lex.europa.eu/legal-content/EN/ TXT/?uri=CELEX:02014L0042-20140519 [last viewed 10.04.2018].

13 Directive (EU) 2016/343 of the European Parliament and of the Council of 9 March 2016 on the strengthening of certain aspects of the presumption of innocence and of the right to be present at the trial in criminal proceedings. OJ, L 65, 11.03.2016, pp. 1/11. Available: https://eur-lex.europa.eu/ legal-content/EN/ALL/?uri=CELEX:32016L0343 [last viewed 10.04.2018]. 
11) Directive (EU) 2016/800 of the European Parliament and of the Council of 11 May 2016 on procedural safeguards for children who are suspects or accused persons in criminal proceedings ${ }^{14}$;

12) Directive (EU) 2016/1919 of the European Parliament and of the Council of 26 October 2016 on legal aid for suspects and accused persons in criminal proceedings and for requested persons in European arrest warrant proceedings ${ }^{15}$.

Notably, Latvia has been comparatively well-disciplined in abiding by the terms for transposition, although minor or slightly more significant delays in this respect have occurred. The data included in Table 1 clearly illustrate the timeline of the EU Directives' transposition.

Table 1

\begin{tabular}{|l|c|l|}
\hline \multicolumn{1}{|c|}{ Directive } & $\begin{array}{c}\text { Transposition } \\
\text { date set in the } \\
\text { Directive }\end{array}$ & $\begin{array}{l}\text { Norms of the Directive introduced } \\
\text { into CPL }\end{array}$ \\
\hline $\begin{array}{l}\text { Directive 2010/64/EU of the European } \\
\text { Parliament and of the Council of 20 October } \\
\text { 2010 on the right to interpretation and } \\
\text { translation in criminal proceedings }\end{array}$ & 27.10 .2013 & $\begin{array}{l}23.05 .2013 \text { Amendments to the } \\
\text { Criminal Procedure Law, entry } \\
\text { into force 27.10.2013 }\end{array}$ \\
\hline $\begin{array}{l}\text { Directive 2011/36/EU of the European } \\
\text { Parliament and of the Council of 5 April } \\
\text { 2011 on preventing and combating } \\
\text { trafficking in human beings and protecting } \\
\text { its victims, and replacing council framework } \\
\text { decision 2002/629/JHA }\end{array}$ & 06.04 .2013 & $\begin{array}{l}20.12 .2012 \text { Amendments to the } \\
\text { Criminal Procedure Law, entry } \\
\text { into force 01.04.2013 } \\
23.05 .2013 \text { Amendments to the } \\
\text { Criminal Procedure Law, entry } \\
\text { into force 27.10.2013 }\end{array}$ \\
\hline $\begin{array}{l}\text { Directive 2011/93/EU of the European } \\
\text { Parliament and of the Council of } \\
\text { 13 December 2011 on combating the sexual } \\
\text { abuse and sexual exploitation of children } \\
\text { and child pornography, and replacing } \\
\text { Council Framework Decision 2004/68/JHA }\end{array}$ & 18.12 .2013 & $\begin{array}{l}29.05 .2014 \text { Amendments to the } \\
\text { Criminal Procedure Law, entry } \\
\text { into force 25.06.2014 }\end{array}$ \\
\hline
\end{tabular}

14 Directive (EU) 2016/800 of the European Parliament and of the Council of 11 May 2016 on procedural safeguards for children who are suspects or accused persons in criminal proceedings. OJ, L 132, 21.05.2016, pp. 1/20. Available: https://eur-lex.europa.eu/legal-content/EN/TXT/?uri= CELEX:32016L0800 [last viewed 10.04.2019].

15 Directive (EU) 2016/1919 of the European Parliament and of the Council of 26 October 2016 on legal aid for suspects and accused persons in criminal proceedings and for requested persons in European arrest warrant proceedings. OJ, L 297, 04.11.2016, pp. 1/8. Consolidated version available: https://eur-lex.europa.eu/legal-content/EN/TXT/?uri=CELEX:02016L1919-20161104 [last viewed 10.04.2019].

16 Grozijumi Kriminālprocesa likumā [Amendments to the Criminal Procedure Law] (23.05.2013). $L V$, 112(4918), 12.06.2013. Entry into force 27.10.2013. Available: https://www.vestnesis.lv/ta/ id/257425-grozijumi-kriminalprocesa-likuma [last viewed 10.04.2018].

17 Grozijumi Kriminālprocesa likumā [Amendments to the Criminal Procedure Law] (20.12.2012). $L V$, 6(4812), 09.01.2013. Entry into force 01.04.2013. Available: https://www.vestnesis.lv/ta/ id/253953-grozijumi-kriminalprocesa-likuma [last viewed 10.04.2019].

18 Grozijjumi Kriminālprocesa likumā [Amendments to the Criminal Procedure Law] (29.05.2014). $L V$, 113(5173), 11.06.2014. Entry into force 25.06.2014. Available: https://www.vestnesis.lv/ta/ id/266815-grozijumi-kriminalprocesa-likuma [last viewed 10.04.2019]. 


\begin{tabular}{|c|c|c|}
\hline Directive & $\begin{array}{c}\text { Transposition } \\
\text { date set in the } \\
\text { Directive }\end{array}$ & $\begin{array}{l}\text { Norms of the Directive introduced } \\
\text { into CPL }\end{array}$ \\
\hline $\begin{array}{l}\text { Directive 2011/99/EU of the European } \\
\text { Parliament and of the Council of } \\
13 \text { December } 2011 \text { on the European } \\
\text { protection order }\end{array}$ & 11.01 .2015 & $\begin{array}{l}\text { 29.01.2015 Amendments to the } \\
\text { Criminal Procedure Law, entry } \\
\text { into force } 25.02 .2015^{19}\end{array}$ \\
\hline $\begin{array}{l}\text { Directive 2012/13/EU of the European } \\
\text { Parliament and of the Council of } 22 \text { May } \\
2012 \text { on the right to information in criminal } \\
\text { proceedings }\end{array}$ & 02.06 .2014 & $\begin{array}{l}\text { 23.05.2013 Amendments to the } \\
\text { Criminal Procedure Law, entry } \\
\text { into force } 27.10 .2013\end{array}$ \\
\hline $\begin{array}{l}\text { Directive 2012/29/EU of the European } \\
\text { Parliament and of the Council of } 25 \text { October } \\
2012 \text { establishing minimum standards on } \\
\text { the rights, support and protection of victims } \\
\text { of crime, and replacing Council Framework } \\
\text { Decision 2001/220/JHA }\end{array}$ & 16.11 .2015 & $\begin{array}{l}\text { 18.02.2016 Amendments to the } \\
\text { Criminal Procedure Law, entry } \\
\text { into force } 23.03 .2016^{20}\end{array}$ \\
\hline $\begin{array}{l}\text { Directive 2013/48/EU of the European } \\
\text { Parliament and of the Council of } 22 \text { October } \\
2013 \text { on the right of access to a lawyer in } \\
\text { criminal proceedings and in European } \\
\text { arrest warrant proceedings, and on the } \\
\text { right to have a third party informed upon } \\
\text { deprivation of liberty and to communicate } \\
\text { with third persons and with consular } \\
\text { authorities while deprived of liberty }\end{array}$ & 27.11 .2016 & $\begin{array}{l}\text { 18.02.2016 Amendments to the } \\
\text { Criminal Procedure Law, entry } \\
\text { into force 23.03.2016 }\end{array}$ \\
\hline $\begin{array}{l}\text { Directive 2014/41/EU of the European } \\
\text { Parliament and of the Council of } 3 \text { April } \\
2014 \text { regarding the European Investigation } \\
\text { Order in criminal matters }\end{array}$ & 22.05 .2017 & $\begin{array}{l}\text { 30.03.2017 Amendments to the } \\
\text { Criminal Procedure Law, entry } \\
\text { into force } 12.04 .2017^{21}\end{array}$ \\
\hline $\begin{array}{l}\text { Directive 2014/42/EU of the European } \\
\text { Parliament and of the Council of } 3 \text { April } \\
2014 \text { on the freezing and confiscation of } \\
\text { instrumentalities and proceeds of crime in } \\
\text { the European Union }\end{array}$ & 04.10 .2016 & $\begin{array}{l}\text { 22.06.2017 Amendments to the } \\
\text { Criminal Procedure Law, entry } \\
\text { into force } 01.08 .2017^{22}\end{array}$ \\
\hline
\end{tabular}

19 Grozijumi Kriminālprocesa likumā [Amendments to the Criminal Procedure Law] (29.01.2015). $L V, 29(5347), 11.02 .2015$. Entry into force 25.02.2015. Available: https://www.vestnesis.lv/ta/ id/272127-grozijumi-kriminalprocesa-likuma [last viewed 10.04.2019].

20 Grozijjumi Kriminālprocesa likumā [Amendments to the Criminal Procedure Law] (18.02.2016). $L V, 48(5620), 09.03 .2016$. Entry into force 23.03.2016. Available: https://www.vestnesis.lv/ta/ id/280784-grozijumi-kriminalprocesa-likuma [last viewed 10.04.2019].

21 Grozijumi Kriminālprocesa likumā [Amendments to the Criminal Procedure Law] (30.03.2017). $L V$, 75(5902), 12.04.2017. Entry into force 26.04.2017. Available: https://www.vestnesis.lv/ op/2017/75.5 [last viewed 10.04.2019].

22 Grozijumi Kriminālprocesa likumā [Amendments to the Criminal Procedure Law] (22.06.2017). $L V$, 132(5959), 05.07.2017. Entry into force 01.08.2017. Available: https://www.vestnesis.lv/ op/2017/132.9 [last viewed 10.04.2019]. 


\begin{tabular}{|l|c|l|}
\hline \multicolumn{1}{|c|}{ Directive } & $\begin{array}{c}\text { Transposition } \\
\text { date set in the } \\
\text { Directive }\end{array}$ & $\begin{array}{c}\text { Norms of the Directive introduced } \\
\text { into CPL }\end{array}$ \\
\hline $\begin{array}{l}\text { Directive (EU) 2016/343 of the European } \\
\text { Parliament and of the Council of 9 March } \\
2016 \text { on the strengthening of certain aspects } \\
\text { of the presumption of innocence and of the } \\
\text { right to be present at the trial in criminal } \\
\text { proceedings }\end{array}$ & 01.04 .2018 & $\begin{array}{l}\text { 27.09.2018 Amendments to the } \\
\text { Criminal Procedure Law, entry } \\
\text { into force 25.10.2018 }\end{array}$ \\
\hline $\begin{array}{l}\text { Directive (EU) 2016/800 of the European } \\
\text { Parliament and of the Council of 11 May } \\
\text { 2016 on procedural safeguards for children } \\
\text { who are suspects or accused persons in } \\
\text { criminal proceedings }\end{array}$ & 11.06 .2019 & $\begin{array}{l}\text { 27.09.2018 Amendments to the } \\
\text { Criminal Procedure Law, entry } \\
\text { into force 25.10.2018 }\end{array}$ \\
\hline $\begin{array}{l}\text { Directive (EU) 2016/1919 of the European } \\
\text { Parliament and of the Council of 26 October } \\
\text { 2016 on legal aid for suspects and accused } \\
\text { persons in criminal proceedings and for } \\
\text { requested persons in European arrest } \\
\text { warrant proceedings. }\end{array}$ & 05.05 .2019 & $\begin{array}{l}\text { 27.09.2018 Amendments to the } \\
\text { Criminal Procedure Law, entry } \\
\text { into force 25.10.2018 }\end{array}$ \\
\hline
\end{tabular}

\section{General Characteristics of Impact of EU Directives on Content Development of CPL Norms}

Characterising the trends in the content of the EU Directives, it must be noted, as indicated in previous publications that the EU's activities in regulating issues of criminal procedure could be, conditionally, split into two directions the area of legal cooperation and influencing procedural order and form of the so-called 'national' criminal proceedings, by setting the minimum standards for criminal procedural guarantees or rules $^{24}$. In the area of legal cooperation, the work, basically, is aimed at making the legal cooperation between the EU Member States more effective, by introducing and reinforcing instruments of cooperation based on the so-called principle of mutual recognition. This line was particularly active in the EU, when the different framework decisions on matters of cooperation were adopted, whereas in the Member States - when these decisions were implemented ${ }^{25}$. Currently, this line of work, perhaps, is less intensive, yet still on-going, in introducing both new instruments that are based on the

23 Grozijjumi Kriminālprocesa likumā [Amendments to the Criminal Procedure Law] (27.09.2018). $L V$, 201(6287), 11.10.2018. Entry into force 25.10.2018. Available: https://www.vestnesis.lv/ op/2018/201.2 [last viewed 10.04.2019].

24 See for example Strada-Rozenberga, K. EU Criminal Justice - Development Trends and Impact in Latvia. In: Collection of research papers in conjunction with the International Scientific Conference "The Quality of Legal Acts and its importance in Contemporary Legal Space", 4-5 October, 2012. Riga: University of Latvia, 2012, pp. 423-435.

25 See for example Strada-Rozenberga, K. Savstarpējās atzī̌sanas princips starptautiskajā kriminālprocesuālajā sadarbībā Eiropas Savienības telpā - teorija un prakse [Principle of Mutual Recognition in International Criminal Proceedings in the European Union - Theory and Practice]. In: Eiropas Savienība un tiesiska valsts: Latvijas pieredze. Rakstu krājums. Rīga: Riga Graduate School of Law, 2009, pp. 159-173; Melnace, I. Top apjomīgi grozījumi Kriminālprocesa likuma C dal̦ā [Work is underway on major amendments to Part C of the Criminal Procedure Law]. Jurista Vārds, No. 7(706), 2012. Available: http://www.juristavards.lv/index.php?menu=DOC\&id=243967 [last viewed 10.04.2019]. 
principle of mutual recognition and reinforcing the existing ones. Thus, out of 12 EU Directives, the norms derived from which were introduced into CPL, two envisage new instruments based on the principle of mutual recognition - European Protection Order (Directive 2011/99/EU) and European Investigation Order (Directive 2014/41/EU). A number of Directives could be recognised as such that are not intended for introducing a new instrument but rather for improving the effectiveness of the existing ones. A good example of this is Directive 2014/42/EU of the European Parliament and of the Council of 3 April 2014 on the freezing and confiscation of instrumentalities and proceeds of crime in the European Union.

Whereas changes in the legal regulation on the so-called 'national' criminal procedure, which follow from the need to transpose the norms included in the EU Directives, take various directions. One of these - application of the minimum procedural guarantees to certain participants of the proceedings. These requirements follow both from those EU Directives, which have been adopted for the purpose of reinforcing the principle of mutual recognition, as, for example, Directives 2010/64/EU, 2012/13/EU, 2012/29/EU, (EU) 2016/1919, (EU) 2016/343, (EU) $2016 / 800$, as well as those aimed at effectively combatting certain offences and the need for specific protection for the victims of these offences, as Directives 2011/36/EU and 2011/92/EU. The reinforcement of the procedural guarantees, predominantly, applies to two groups of persons - persons, who have the right to defence, and victims.

Another direction in the EU's activities that has influenced amendments to the CPL norms is making some institutions of criminal law more effective and, in particular, legal regulation on freezing and confiscation of the proceeds of crime, instrumentalities of criminal offences, etc., as well as ensuring the interests of persons linked to these matters. Undeniably, the aim of making criminal proceedings regarding certain types of offences more effective has also been in the focus of other Directives (for example, Directive 2011/36/EU or Directive 2011/92/ $\mathrm{EU})$, for instance, envisaging that criminal proceedings with respect to certain types of crimes should be conducted irrespectively of the victim's wishes and even if he withdraws his application. However, the norms of these Directives cannot be considered as being such that have influenced the development of CPL since they did not require amendments to CPL, the previous provisions of which coincided with those of the Directives.

In view of the wish to focus, in this article, on the procedural guarantees for the participants of criminal proceedings, in particular, their rights and ensuring of these rights, hereinafter the focus will be on those EU Directives, which have been adopted and transposed into the national law for this purpose. I hold that the norms of the EU Directives, which are aimed at ensuring and reinforcing the minimum rights of the participants of criminal proceedings, could be divided into two groups - 1) those, which are applicable to any participant of criminal proceedings who complies with the respective status, for example, a victim of a criminal offence or a suspect, the accused person, and 2) those that are applicable to a specially singled out group of participants of the proceedings, which due to certain characteristics (a set of characteristics) require specific protection.

Directives 2010/64/EU, 2012/13/EU, 2013/48/EU, (EU) 2016/343, (EU) 2016/1919 can be mentioned as an example of those EU Directives that are applicable to all participants of criminal proceedings, who have obtained the respective status; these apply to any person, with respect to which competent officials have made 
an assumption that they have committed a criminal offence, as well as Directive 2012/29/EU, which defines the minimum standards regarding the rights, support and protection of victims of a criminal offence.

In assessing the changes made in the Latvian laws by transposing the norms of these Directives with respect to all persons having the respective procedural statuses, it can be recognised that these changes should not be deemed as being fundamental, since, basically, the respective statuses and the fundamental rights typical of these were envisaged in CPL even before the respective EU Directives were adopted. Some amendments were needed to specify some matters, to expand the understanding of some rights, etc. ${ }^{26}$ These aspects will not be examined in detail here in view of the fact that the most substantial amendments to CPL are linked to ensuring the rights of the so-called participants of criminal proceedings in need of specific protection.

The following can be singled out as groups in need of specific protection, the minimum rights of which, in accordance with the regulation of the EU Directives, require special attention: 1) victims of criminal offences who enjoy specific protection, taking into account the criminal offence that they have been the target of, and / or their special condition, etc. 2) children with various procedural statuses, and 3) persons, who have been deprived of liberty during the proceedings. Considering the scope of this topic and the limit set for the size of this article, the focus will remain on the procedural safeguarding of victims in need of specific protection.

\section{Victims with Specific Protection Needs and Reinforcing Protection of Their Interests}

Reinforcing the protection of the victims of criminal offences has been in the centre of EU law policy over a long period of time, which is proven by the comparatively vast range of regulatory enactments on this issue. Admittedly, neither the existence of a victim's status per se nor the possibilities of these persons to participate actively in the criminal proceedings are new for the Latvian criminal procedure because the victim as an active participant of the criminal proceedings has been known in Latvia for decades. At the same time, it cannot be denied that the category of victims in need of specific protections was not too well-known in

26 See for more details Dundurs, Z. Eiropas Savienības procesuālās tiesības kriminālprocesā [European Union Procedural Rights in Criminal Proceedings]. Jurista Vārds, No. 33(680), 2011. Available: http://www.juristavards.lv/index.php?menu=DOC\&id=234351 [last viewed 10.04.2019]; Strada-Rozenberga, K. EU Criminal Justice - Development Trends and Impact in Latvia. In: Collection of research papers in conjunction with the International Scientific Conference "The Quality of Legal Acts and its importance in Contemporary Legal Space”, 4-5 October, 2012. Riga: University of Latvia, 2012, pp. 423-435; Meikališa, Ā. Jaunas vēsmas cietušo aizsardzībā ES direktīva par cietušā tiesību minimālajiem standartiem un tās iespējamā ietekme uz kriminālprocesu Latvijā [New Trends in Victim Protection - the EU Directive on the Minimum Standards in the Victims' Rights and its Possible Impact upon Criminal Procedure in Latvia]. In: LU 71. konferences rakstu krājums “Tiesību interpretācija un tiesību jaunrade”. Rīga: University of Latvia Press, 2013, pp. 140-146; Meikališa, $\bar{A}$. Victims in Criminal Procedure: A Review of Latvian Criminal Procedure Norms through the Prism of Minimal EU Standards. Journal of the University of Latvia. Law. Riga: University of Latvia, No. 6, 2014, pp. 4-19; Strada-Rozenberga, K. Victims and their Criminal Procedure Status and Law Enforcement Practices in Latvia. Journal of the University of Latvia. Law. Riga: University of Latvia, No. 6, 2014, pp. 51-90. 
the Latvian CPL, therefore, the transposition of the norms from the EU directives pertaining to this aspect brought innovation ${ }^{27}$.

The following EU Directives define the specific procedural requirements with respect to victims belonging to special groups: Directive 2011/36/EU of the European Parliament and of the Council of 5 April 2011 on preventing and combating trafficking in human beings and protecting its victims, and replacing council framework decision 2002/629/JHA and Directive 2011/92/EU of the European Parliament and of the Council of 13 December 2011 on combating the sexual abuse and sexual exploitation of children and child pornography, and replacing Council Framework Decision 2004/68/JHA, as well as Directive 2012/29/ EU of the European Parliament and of the Council of 25 October 2012 establishing minimum standards on the rights, support and protection of victims of crime, and replacing Council Framework Decision 2001/220/JHA.

The examination of these Directives in their interconnection allows singling out the following groups of victims in need of specific protection:

1) Children (Directive 2011/36/EU, article 15, 2011/92/EU, 2012/29/EU, article 22-24);

2) Victims of trafficking in human beings (Directive 2011/36/EU);

3) Victims recognised as being in need of specific protection in accordance with Directive 2012/29/EU, article 22.

In view of the fact that children are a special category of victims allotted the highest level of protection, they have all the rights that other groups of victims in need of specific protection have and, additionally, rights that are typical only of children, there is a good reason to begin the overview with other groups of victims.

The following can be indicated as the most significant additional guarantees, envisaged by Directive 2011/36/EU for adult victims of trafficking in human beings:

- access without delay to legal counselling and legal representation, which must be provided free of charge to the persons who do not have sufficient financial resources (article 12(2));

- individual risk assessment (article 12(3));

- particularities in conducting investigatory activities, for example, avoiding unnecessary repetition of interviews, avoiding visual contact between victims and defendants, unnecessary questioning concerning the victim's private life, etc.) (article 12(4));

- non-prosecution and non-application of penalties to the victims for the offences that they have committed while being victims of trafficking in human beings (article 8).

Notwithstanding the diversity of peculiarities in conducting the proceedings with victims of trafficking in human beings, envisaged in Directive 2011/36/EU, when it was transposed into the CPL norms, only a couple of amendments were made, the most important of which - aligned with the Criminal Law ${ }^{28}$ - was the possibility that was introduced to release from criminal liability a person, who had committed a criminal offence at the time when he has been subject to trafficking in

27 See for example Meikališa, Ā. Victims in Criminal Procedure: A Review of Latvian Criminal Procedure Norms through the Prism of Minimal EU Standards. Journal of the University of Latvia. Law. Riga: University of Latvia, No. 6, 2014, pp. 4-19.

28 Krimināllikums [Criminal Law] (17.06.1998). Consolidated version available in Latvian: https:// likumi.lv/doc.php?id=88966, in English: https://likumi.lv/ta/en/en/id/88966 [last viewed 10.04.2018]. 
human beings and forced to commit it (see CPL, para. 5 of section 379(1)). Other peculiarities were not directly transposed into CPL; apparently, the legislator accepted the approach that these peculiarities were already observed in the Latvian criminal procedure, by applying appropriately the CPL norms of general nature (for example, on inviolability of private life, conducting investigatory activities according to need and by interfering into person's life as little as possible, etc.). Likewise, the fact that the Directive's style of expression is rather 'soft' should be taken into account, it leaves the enforcement of many requirements (for example, avoiding giving of testimony at an open court hearing) at the Member States' discretion. Notably, in later years, the Latvian legislator took a more detailed approach to the transposition of Directives and included in CPL references to more peculiarities that must be complied with in the treatment of victims belonging to certain groups. This, in particular, applies to the transposition of Directive 2012/29/EU.

Beginning the overview of Directive 2012/29/EU, it should be noted that article 22 provides that Member States must ensure that victims receive a timely and individual assessment to identify specific protection needs. It must be noted that until then the individual assessment of victims was not included in CPL. Article $96^{1}$ "Specially Protected Victim" was included in CPL as an alternative, providing that without conducting any special assessment, the following victims had to be specially protected: 1) a child victim; 2) a person who is not able to completely exercise his or her procedural rights due to a mental or other health deficiencies; 3) a person who has suffered from a criminal offence directed against the morality or sexual inviolability of a person, or from human trafficking; 4) a person who has suffered from a criminal offence related to violence or threat of violence and committed by a member of the immediate family, former spouse of the victim or by a person with whom the victim was in constant intimate relationship; 5) a person who, as a result of a criminal offence, has been, possibly, inflicted serious bodily injuries or mental impairments; 6) a person who has suffered from a criminal offence, possibly, committed due to racial, national, ethnic, or religious reasons. Besides, by a decision of the person directing the proceedings also a victim who is not referred to above, but who, due to the harm inflicted as a result of a criminal offence, is particularly vulnerable and is not protected from repeated threat, intimidation, or revenge, has to be recognised as a specially protected victim. Hence, the institution of victims' individual assessment has not been introduced in Latvia ${ }^{29}$, at the same time automatic granting of the status of a victim in need of specific protection has been granted to victims of certain criminal offences, as well as to persons, who are recognised as being in need of specific protection by the official in charge of the proceedings, on the basis of a case-by-case assessment. Assumedly, the official in charge of the proceedings, in deciding on granting the status of a victim in need of specific procedural protection, on the basis of a case-by-case assessment, must take into account the circumstances defined in article 22(3) of Directive 2012/29/EU, article 22(3) and the explanation provided in Recital (57-58) of this Directive.

In transposing the procedural peculiarities in working with victims in need of specific protection defined in Directive 2012/29/EU, the following additional rights were added to CPL, which are not characteristic of other persons recognised as being victims:

29 An individual assessment, meeting the requirements of Directive (EU) 2016/800, was included into CPL only with respect to minors enjoying the right to defence. 
- participation in procedural activities, with permission of the person directing the proceedings, together with the trusted person, unless it is a person against whom criminal proceedings have been initiated, a detained, a suspect, or an accused;

- right to request and receive information regarding release or escape of such arrested or convicted person from a place of imprisonment or a place of temporary detention who has inflicted harm to him or her, if there is a threat to the victim and there is no risk of harm to the arrested or convicted person;

- right to request that his or her participation and hearing in a court session takes place using technical means;

- peculiarities in interrogation - interrogation of a specially protected victim is performed in a separate room appropriate for such purposes or without the presence of persons not related to the particular procedural action. Interrogation of such person who has been recognised as a victim of violence committed by a person upon whom the victim is dependent financially or otherwise, a victim of human trafficking, or a criminal offence directed against morality or sexual inviolability of the person, must be conducted by a performer of an investigative action of the same gender. The abovementioned condition need not be conformed to, if the victim himself or herself or his or her representative agrees thereto. If the victim of a criminal offence directed against morality or sexual inviolability of a person and the person who has the right to defence is of the same gender and if it is requested by the victim or his or her representative, the interrogation must be performed by a performer of an investigative action of the opposite gender.

It can be concluded that the majority of the additional requirements that Directive 2012/29/EU sets for working with victims in need of specific protection have been transposed into CPL. To enforce some requirements, no amendments were necessary. Thus, for example, the measure envisaged in article 13(3a) of Directive 2012/29/EU to avoid unnecessary questioning of the victim about his private life, was already included in a number of the CPL norms, whereas the requirement to include measures for hearing the case at a closed court hearing can be met by abiding by the CPL norm, that a court may decide, on the basis of a reasoned decision, decide to hold a closed court hearing "to ensure the protection of persons involved in criminal proceedings".

As noted above, children are a special group of victims in need of specific protection, which is characterised by all the procedural guarantees referred to above, and, additionally, those that have been set specifically for children. Children as a category of victims in need of specific protection have been envisaged in all three EU Directives dedicated to victims - articles 19-20 of Directive 2011/92/EU, articles 15-16 of Directive 2011/36/EU, and article 24 of Directive 2012/29/EU, respectively, focus on the protection thereof.

The general analysis of these norms leads to the conclusion that all Directives share the same understanding of the concept 'child', which is applied to a person below the age of 18 . This opinion is fully aligned with the CPL provision on granting the status of a victim in need of specific protection to a minor, i.e., a person who has not reached the age of 18 . Although Latvian laws provide for the possibility, in some cases, to obtain civil law age of majority from the age of 16, the peculiarities of the criminal procedure that are typical of 'a child' are applicable to all persons below the 
age of $18^{30}$. In this respect, it seems that there are grounds to initiate a discussion on, whether and, if yes, for how long the procedural peculiarities should be applicable to a person, who had become a victim while being a child and reached majority during the proceedings. A proposal would be to apply rules equal to the ones provided by Directive (EU) 2016/800 with respect to children, who are suspects or accused persons. Otherwise, at present no objective grounds can be discerned for the entitlement of additional procedural guarantees for the suspects or accused persons, who committed the offence while being children but reached the age of 18 during the proceedings, whereas the victims of the same age are not entitled to them ${ }^{31}$. As a response to an objection that can be anticipated that those who have reached the age of 18 could be recognised as being victims in need of specific protection on the basis of other characteristics, it can be noted that the scope of procedural guarantees for child victims is larger than that of other victims in need of specific protection.

Examining the content of procedural guarantees envisaged for child victims, it can be recognised that articles 19-20 of Directive 2011/92/EU, articles 15-16 of Directive 2011/36/EU, actually, define the same peculiarities (additional procedural guarantees) for working with children who have become victims of trafficking in human beings, sexual abuse and sexual exploitation and child pornography. The following can be mentioned as the main ones: the right to representation and legal assistance free of charge; peculiarities of interrogation (inter alia, special premises, prohibition of unfounded delay, the same person conducting the interrogation, making an audio-visual recording of the interview and subsequent use of this recording). As mentioned above and can be reiterated here, the transposition of these directives into the CPL norms was done 'minimally'. Thus, for example, the majority of interrogation peculiarities at the time were not included and, actually, were added to the text of CPL significantly later - when the norms of Directive 2012/29/EU were transposed.

The norms of Directive 2012/29/EU, which are characteristic of victims in need of specific procedural protection, including children, already were examined. Additional peculiarities, typical of the procedural measures for child victims, envisaged by this Directive is the audio-visual recording of the interviews and the use of these recordings, the existence of a special representative and ensuring legal assistance (see article 24).

The general review of the transposition of the examined Directives in the Latvian CPL allows concluding that, presently, all requirements, in fact, have been met - a child victim is ensured appropriate representation, mandatory legal assistance free of charge, a trusted person may participate in the proceedings, and CPL comprises also all the peculiarities included in the Directives regarding interrogation, making an audio-visual recording of interrogations, and also provides that a case, involving a child, is heard at closed court hearing. The transposition of Directives has resulted in a significant increase in the peculiarities in working with child victims, which previously were linked only to representation and some peculiarities of interrogation.

30 Bërnu tiesibu aizsardzibas likums [Law on the Protection of the Children's Rights] (19.06.1998). Consolidated version available in Latvian: https://likumi.lv/ta/id/49096-bernu-tiesibu-aizsardzibas-likums, in English: https://likumi.lv/ta/en/en/id/49096 [last viewed 10.04.2018].

31 However, it must be noted that currently, although Directive (EU) 2016/800 is indicated as transposed, CPL contains no disclaimer stating that the procedural peculiarities envisaged with respect to a minor who enjoys the right to defence should be applied to him also after he has come of age. 
In conclusion, it has to be recognised that the EU Directives have had an important role in improving the CPL norms, in particular, in relation to the procedural guarantees of a victim in need of specific protection, inter alia, a child. Prior to the transposition thereof, only children were seen as a special group of victims, whereas now the category of victims in need of specific protection is significantly broader. Hence, the procedural peculiarities are applicable also to such persons, the proceedings with respect to which were conducted without any peculiarities. The range of procedural peculiarities in working with children is much more extensive. Hence, the legal instruments have been created, it only remains to apply these successfully in practice.

\section{Summary}

1. The need to transpose the EU legal norms has been a significant cause of amendments to the Criminal Procedure Law. Out of 35 laws on amendments to the Criminal Procedure Law, at least 14 followed from, inter alia, the need to transpose the EU norms.

2. In assessing not only the numeric impact on the amendments to the Criminal Procedure Law by the transposition of the EU norms but also their significance content-wise, it must be recognised that it had been the decisive cause for introducing amendments to the norms of Part $\mathrm{C}$ of the Criminal Procedure Law "International Cooperation in the Criminal-legal Field". Whereas with respect to Part A (General Provisions) and Part B (Pre-trial Criminal Proceedings and Court Proceedings in Criminal Cases) of the Criminal Procedure Law, which, basically, apply to the criminal proceedings conducted in Latvia, the share of the CPL norms influenced by the EU norms is smaller but these, nevertheless, are significant.

3. Currently, the Criminal Procedure Law comprises norms that follow from 12 EU Directives.

4. Latvia has been rather well-disciplined in meeting the terms for transposing the EU Directives, although minor and slightly more significant delays have occurred.

5. The EU Directives have influenced the development of the CPL norms in two segments - regulation of the criminal law cooperation in the framework of the EU and the legal model of the so-called "local" criminal proceedings. With respect to the latter, two trends in development can be discerned - setting minimum procedural guarantees for persons involved in criminal proceedings and making some instruments of criminal procedure more effective.

6. The norms of EU Directives aimed at ensuring the minimum rights of the participants of criminal proceedings, can be divided into groups - 1) those, which are applicable to any participant of criminal proceedings who complies with the respective status, for example, a victim of a criminal offence or a suspect, the accused person, and 2) those that are applicable to a specially singled out group of participants of the proceedings, which due to a certain characteristics (set of characteristics) require specific protection.

7. The following can be singled out as groups in need of specific protection, whose minimum rights have been the focus of special attention, in accordance with the regulation of the EU Directives: 1) victims of criminal offences who enjoy specific protection, taking into account the criminal offence that they have been 
the target of and / or they special condition, etc.; 2) persons, who have been deprived of liberty during the proceedings; 3 ) children with various procedural statuses, and

8. Although the examined EU Directives envisage the need of an individual assessment in all cases, where there could be grounds for granting the status of needing specific protection to any participant of the criminal proceedings (to the victim or the possible perpetrator), the Criminal Procedure Law provides for such an assessment only for a person, who enjoys a minor's right to defence. An individual assessment has not been introduced with respect to other victims, however, a broad range of cases is envisaged, where the granting of this status to a person is mandatory, it is also envisaged that the official in charge of the proceedings may grant it also in any other instance, when he deems it to be necessary. In deciding on this issue, the person in charge of the proceedings should abide by the considerations indicated in Directive 2012/29/EU.

9. Children, i.e., persons below the age of 18 , are a special category of victims in need of protection. Neither the texts of Directives nor CPL provide expressis verbis that the procedural guarantees that are typical of a child victim should be applied to him also if he has come of age during the proceedings. Assumedly, in such a situation, a solution analogue to the provisions of Directive (EU) 2016/800 should be introduced, and these peculiarities or, at least, a part thereof should be applicable to the victim for some time, later on retaining the procedural guarantees of a victim in need of specific protection but not those of a child.

10. Basically, the requirements of Directives regarding work with victims in need of specific protection, inter alia, children, have been transposed. Predominantly, this has been done by transposing into the Criminal Procedure Law the norms of Directive 2012/29/EU.

11. The transposition of the norms of the EU Directives has played a significant role in improving the CPL provisions regarding the procedural guarantees for a victim in need of specific protection, inter alia, children. Prior to the transposition thereof, only children were seen as a special group of victims, whereas now the category of victims in need of specific protection is significantly broader. Hence, the procedural peculiarities are applicable also to such persons, the proceedings with respect to which were conducted without any peculiarities. The range of procedural peculiarities in working with children is much more extensive.

\section{Sources}

\section{Bibliography}

1. Dundurs, Z. Eiropas Savienības procesuālās tiesības kriminālprocesā [European Union Procedural Rights in Criminal Proceedings]. Jurista Värds, No. 33(680), 2011. Available: http://www.juristavards. lv/index.php? menu=DOC\&id $=234351$ [last viewed 10.04.2019].

2. Meikališa, $\bar{A}$. Victims in Criminal Procedure: A Review of Latvian Criminal Procedure Norms through the Prism of Minimal EU Standards. Journal of the University of Latvia. Law. Riga: University of Latvia, No. 6, 2014, pp. 4-19.

3. Meikališa, Ā. Jaunas vēsmas cietušo aizsardzībā - ES direktīva par cietušā tiesību minimālajiem standartiem un tās iespējamā ietekme uz kriminālprocesu Latvijā [New Trends in Victim Protection - the EU Directive on the Minimum Standards in the Victims' Rights and its Possible Impact upon Criminal Procedure in Latvia]. In: LU 71. konferences rakstu kräjums "Tiesību interpretācija un tiesību jaunrade”. Rīga: University of Latvia Press, 2013, pp. 140-146. 
4. Meikališa, $\bar{A}$. Kriminālprocesa likumam 10 - fakti, vērtējumi, prognozes [The $10^{\text {th }}$ Anniversary of the Criminal Procedure Law - Facts, Assesments, Forecasts]. In: Meikališa, Ā., Strada-Rozenberga, K. Kriminālprocess. Raksti 2010-2015. Rīga: Latvijas Vēstnesis, 2015, pp. 95-150.

5. Melnace, $I$. Top apjomīgi grozijumi Kriminālprocesa likuma $\mathrm{C}$ dạ̦ā [Work is under way on major amendments to Part C of the Criminal Procedure Law]. Jurista Värds, No. 7(706), 2012. Available: http://www.juristavards.lv/index.php?menu=DOC\&id=243967 [last viewed 10.04.2019].

6. Strada-Rozenberga, K. Savstarpējās atzīšanas princips starptautiskajā kriminālprocesuālajā sadarbībā Eiropas Savienības telpā - teorija un prakse [Principle of Mutual Recognition in International Criminal Proceedings in the European Union - Theory and Practice]. In: Eiropas Savienība un tiesiska valsts: Latvijas pieredze. Rakstu kräjums. Rīga: Riga: Riga Graduate School of Law, 2009, pp. 159-173.

7. Strada-Rozenberga, K. EU Criminal Justice - Development Trends and Impact in Latvia. In: Collection of research papers in conjunction with the International Scientific Conference "The Quality of Legal Acts and its Importance in Contemporary Legal Space", 4-5 October, 2012. Riga: University of Latvia, 2012, pp. 423-435.

8. Strada-Rozenberga, K. Victims and their Criminal Procedure Status and Law Enforcement Practices in Latvia. Journal of the University of Latvia. Law. Riga: University of Latvia, No. 6, 2014, pp. 51-90.

\section{Normative Acts}

1. Krimināllikums [Criminal Law] (17.06.1998). Consolidated version available in Latvian: https:// likumi.lv/doc.php?id=88966, in English: https://likumi.lv/ta/en/en/id/88966 [last viewed 10.04.2018].

2. Bērnu tiesību aizsardzibas likums [Law on the Protection of the Children's Rights] (19.06.1998.). Consolidated version available in Latvian: https://likumi.lv/ta/id/49096-bernu-tiesibu-aizsardzibaslikums, in English: https://likumi.lv/ta/en/en/id/49096 [last viewed 10.04.2018].

3. Kriminālprocesa likums [Criminal Procedure Law] (21.04.2005). Consolidated version available in Latvian: https://likumi.lv/doc.php?id=107820, in English: https://likumi.lv/ta/en/en/id/107820 [last viewed 10.04.2018].

4. Grozijumi Kriminālprocesa likumā [Amendments to the Criminal Procedure Law] (23.05.2013). $L V, 112(4918), 12.06 .2013$. Entry into force 27.10.2013. Available: https://www.vestnesis.lv/ta/ id/257425-grozijumi-kriminalprocesa-likuma [last viewed 10.04.2018].

5. Grozijumi Kriminālprocesa likumā [Amendments to the Criminal Procedure Law] (20.12.2012). $L V$, 6(4812), 09.01.2013. Entry into force 01.04.2013. Available: https://www.vestnesis.lv/ta/ id/253953-grozijumi-kriminalprocesa-likuma [last viewed 10.04.2019].

6. Grozijumi Kriminālprocesa likumā [Amendments to the Criminal Procedure Law] (29.05.2014). $L V, 113(5173), 11.06 .2014$. Entry into force 25.06.2014. Available: https://www.vestnesis.lv/ta/ $\mathrm{id} / 266815$-grozijumi-kriminalprocesa-likuma [last viewed 10.04.2019].

7. Grozijumi Kriminālprocesa likumā [Amendments to the Criminal Procedure Law] (29.01.2015). $L V, 29(5347), 11.02 .2015$. Entry into force 25.02.2015. Available: https://www.vestnesis.lv/ta/ id/272127-grozijumi-kriminalprocesa-likuma [last viewed 10.04.2019].

8. Grozijjumi Kriminālprocesa likumā [Amendments to the Criminal Procedure Law] (18.02.2015). $L V$, 48(5620), 09.03.2016. Entry into force 23.03.2016. Available: https://www.vestnesis.lv/ta/ id/280784-grozijumi-kriminalprocesa-likuma [last viewed 10.04.2019].

9. Grozijiumi Kriminālprocesa likumā [Amendments to the Criminal Procedure Law] (22.06.2017). $L V$, 132(5959), 05.07.2017. Entry into force 01.08.2017. Available: https://www.vestnesis.lv/ op/2017/132.9 [last viewed 10.04.2019].

10. Grozijumi Kriminālprocesa likumā [Amendments to the Criminal Procedure Law] (30.03.2017). LV, 75(5902), 12.04.2017. Entry into force 26.04.2017. Available: https://www.vestnesis.lv/op/2017/75.5 [last viewed 10.04.2019].

11. Grozijumi Kriminālprocesa likumā [Amendments to the Criminal Procedure Law] (27.09.2018). $L V$, 201(6287), 11.10.2018. Entry into force 25.10.2018. Available: https://www.vestnesis.lv/ op/2018/201.2 [last viewed 10.04.2019].

12. Directive 2010/64/EU of the European Parliament and of the Council of 20 October 2010 on the right to interpretation and translation in criminal proceedings. OJ, L 280, 26.10.2010, p. 1/7. Available: https://eur-lex.europa.eu/legal-content/EN/TXT/?uri=CELEX:32010L0064 [last viewed 10.04.2018].

13. Directive 2011/36/EU of the European Parliament and of the Council of 5 April 2011 on preventing and combating trafficking in human beings and protecting its victims, and replacing council 
framework decision 2002/629/JHA. OJ, L 101, 15.04.2011, p. 1/11. Available: https://eur-lex.europa. eu/legal-content/EN/TXT/?uri=CELEX:32011L0036 [last viewed 10.04.2018].

14. Directive 2012/13/EU of the European Parliament and of the Council of 22 May 2012 on the right to information in criminal proceedings. OJ, L 142, 01.06.2012, p. 1/10. Available: https://eur-lex. europa.eu/legal-content/EN/ALL/?uri=CELEX:32012L0013 [last viewed 10.04.2018].

15. Directive 2011/92/EU of the European Parliament and of the Council of 13 December 2011 on combating the sexual abuse and sexual exploitation of children and child pornography, and replacing Council Framework Decision 2004/68/JHA. OJ, L 335, 17.12.2011, p. 1/14. Consolidated version available: https://eur-lex.europa.eu/legal-content/EN/TXT/?uri=CELEX:02011L009320111217 [last viewed 10.04.2018].

16. Directive 2011/99/EU of the European Parliament and of the Council of 13 December 2011 on the European protection order. OV, L 338, 21.12.2011, p. 2/18. Available: https://eur-lex.europa.eu/ legal-content/EN/TXT/?uri=CELEX:32011L0099 [last viewed 10.04.2018].

17. Directive 2012/29/EU of the European Parliament and of the Council of 25 October 2012 establishing minimum standards on the rights, support and protection of victims of crime, and replacing Council Framework Decision 2001/220/JHA. OJ, L 315, 14.11.2012, p. 57/73. Available: https:/eur-lex.europa.eu/legal-content/EN/ALL/?uri=CELEX:32012L0029 [last viewed 10.04.2018].

18. Directive 2013/48/EU of the European Parliament and of the Council of 22 October 2013 on the right of access to a lawyer in criminal proceedings and in European arrest warrant proceedings, and on the right to have a third party informed upon deprivation of liberty and to communicate with third persons and with consular authorities while deprived of liberty. OJ, L 294, 06.11.2013. Available: https://eur-lex.europa.eu/legal-content/EN/TXT/?uri=CELEX:32013L0048 [last viewed 10.04.2018].

19. Directive 2014/41/EU of the European Parliament and of the Council of 3 April 2014 regarding the European Investigation Order in criminal matters. OJ, L 130, 01.05.2014, pp. 1/36. Consolidated version available: https://eur-lex.europa.eu/legal-content/LV/TXT/?uri=CELEX:020 14L0041-20140501 [last viewed 10.04.2018].

20. Directive 2014/42/EU of the European Parliament and of the Council of 3 April 2014 on the freezing and confiscation of instrumentalities and proceeds of crime in the European Union. OJ, L 127, 29.04.2014, pp. 39/50. Consolidated version available: https://eur-lex.europa.eu/legal-content/EN/ TXT/?uri=CELEX:02014L0042-20140519 [last viewed 10.04.2018].

21. Directive (EU) 2016/343 of the European Parliament and of the Council of 9 March 2016 on the strengthening of certain aspects of the presumption of innocence and of the right to be present at the trial in criminal proceedings. OJ, L 65, 11.03.2016, pp. 1/11. Available: https://eur-lex.europa.eu/ legal-content/EN/ALL/?uri=CELEX:32016L0343 [last viewed 10.04.2018].

22. Directive (EU) 2016/800 of the European Parliament and of the Council of 11 May 2016 on procedural safeguards for children who are suspects or accused persons in criminal proceedings. OJ, L 132, 21.05.2016, pp. 1/20. Available: https://eur-lex.europa.eu/legal-content/EN/ TXT/?uri=CELEX:32016L0800 [last viewed 10.04.2019].

23. Directive (EU) 2016/1919 of the European Parliament and of the Council of 26 October 2016 on legal aid for suspects and accused persons in criminal proceedings and for requested persons in European arrest warrant proceedings. OJ, L 297, 04.11.2016., pp. 1/8. Consolidated version available: https://eur-lex.europa.eu/legal-content/EN/TXT/?uri=CELEX:02016L1919-20161104 [last viewed 10.04.2019]. 


\title{
Current Constitutional Changes in Poland Against the Background of Polish Political and Legal Traditions
}

\author{
Dr. habil. Anna Rytel-Warzocha \\ Faculty of Law and Administration, University of Gdańsk \\ Adjunct Professor at the Chair of Constitutional Law and Political Institutions \\ E-mail:ania-rytel@prawo.ug.edu.pl \\ Prof. Dr. habil. Andrzej Szmyt \\ Faculty of Law and Administration, University of Gdańsk \\ Full Professor, Head of the Chair of Constitutional Law and Political Institutions \\ E-mail: aszmyt50@wp.pl
}

\begin{abstract}
The article is dedicated to the assessment of the current constitutional changes in Poland and viewing them to explain them in the context of Polish political and legal traditions. The adoption of the Constitution in 1997, based on the principles of political pluralism, democratic rule of law and division of powers, fished the process of the democratic transformation. However, in 2015, by way of statutory legislation and constitutional practice, in cooperation with the President, the new ruling forces started the process of the destruction of Polish constitutional system. A reference to the interwar period is an important motive for the ideology of the leader of the current ruling majority. On the other hand, the concept of the 'political decision-making centre' of the state located outside the state apparatus is anchored in the facade of constitutional solutions from the period of the socialist system.
\end{abstract}

Keywords: Poland, constitutional changes, legal tradition, Constitutional Tribunal.

\section{Contents}

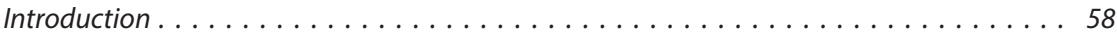

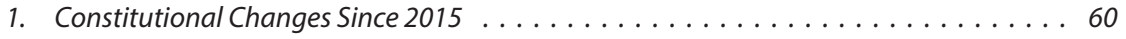

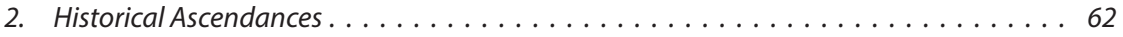

Summary...................................... 64

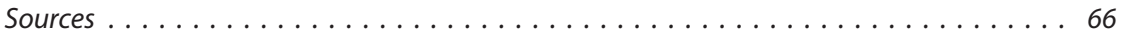

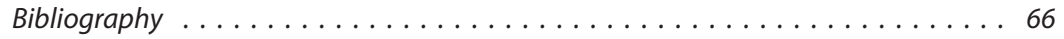

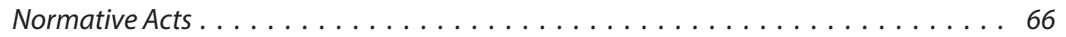

Case Law . . . . . . . . . . . . . . . . . . . . . . . . . 67

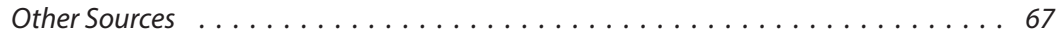

\section{Introduction}

The process of constitutional transformation which led Poland from a socialist system to a democratic state governed by the new Constitution began in the landmark year 1989. The currently binding Constitution of the Republic of Poland 
was adopted by the National Assembly on April 2, 1997 and then it was accepted by the nation in a referendum which took place on May 25, 1997 ${ }^{1}$ In general, the constitutional practice before 2015 was stable and did not arouse controversies, which caused a belief in the stability of constitutional assumptions and political forces' agreement on the axiology and institutional arrangements of the Constitution $^{2}$.

In 2015, right-wing groups came to power in Poland after populist electoral campaigns, winning the presidential elections in the spring and parliamentary elections in the autumn. They have obtained an absolute majority of seats allowing them to create a government and pass laws on their own, however, do not have the qualified majority required to change the Constitution.

By way of legislation and constitutional practice, in cooperation with the President, the new ruling forces started the process of the destruction of Polish constitutional system. Its essence was the elimination of instruments that enable the control over the Parliament and the government. Paralyzing the Constitutional Tribunal in 2016 by the legislative measures as well as the government's refusal to publish the Tribunal's judgements and negating their binding force have become a symbol $^{3}$. In 2017, anti-constitutional political and legal campaign brought a great dispute over the position of common courts, the Supreme Court and the National Council of the Judiciary.

The destructive legislative actions also concerned issues outside the strictly 'third power' field. The changes introduced by ordinary law violated the foundations of basic principles: the rule of law, the division of powers and the independence of courts. According to new statutory regulations, the Prosecutor's Office became subordinated to the executive power and the Minister of Justice obtained (in an unconstitutional way) a significant influence on the judiciary. With an insult to the Constitution, the Act on Civil Service and Foreign Service was amended and the constitutional freedom of assembly was limited.

These changes are accompanied by political practice of making basic decisions outside the structures of state organs, with disregard for democratic and praxeological standards, in falsified and manipulative media setting. In the Parliament, procedures provided as exceptional became the rule ${ }^{4}$. Legislative

$1 \quad$ Konstytucja Rzeczypospolitej Polskiej [Constitutiona of the Republic of Poland] (02.04.2007). The Official Journal of Laws Dziennik Ustaw, No. 78, 1997, item 483, with later amendments. See Szmyt, A. Zakres i treść Konstytucji RP z 1997 r. [The scope and content of the Constitution of the Republic of Poland of 1997]. "Zeszyty Prawnicze" Biura Analiz Sejmowych. Warszawa, No. 4, 2012, pp. 229-234; Sokolewicz, W. (ed.). Zasady podstawowe polskiej Konstytucji [The basic principles of the Constitution of the Republic of Poland]. Warszawa, 1998; Kucinski, J., Wolpiuk, W. J. Zasady ustroju politycznego państwa w Konstytucji Rzeczypospolitej Polskiej z 1997 roku [The principles of the constitutional system in the Constitution of the Republic of Poland of 1997]. Warszawa, 2012.

2 See Jarosz, Z. (ed.). Parlament. Model konstytucyjny a praktyka ustrojowa [Parliament. Constitutional model and the constitutional practice]. Warszawa, 2006; Grzybowski, M. (ed.). System rządów Rzeczypospolitej Polskiej. Założenia konstytucyjne a praktyka ustrojowa [Constitutional system of the Republic of Poland. Constitutional assumptions and constitutional practice]. Warszawa, 2006.

3 See Rytel-Warzocha, A., Szmyt, A. The new law of 2016 on the Constitutional Tribunal in Poland. Annales Universitatis Apulensis. Series Jurisprudentia, No. 19, 2016, pp. 263-290; Szmyt, A. Destruction of the Constitutional Tribunal in Poland in the Light of Opinions of the Venice Commision. In: Giustizia e Constitutione agli albori del XXI Secolo, a cura die L. Mazetti e E. Ferioli. Bologna: Benomo Editore, 2017, tomo 1, pp. 641-656.

4 For example, the possibility of fast legislative path provided by the Standing Orders of the Sejm of the Republic of Poland (30.07.1992). 
works are unprecedentedly fast, which de facto eliminates the possibility of debate. Consultations and public hearings are skipped. Commonly, the bills are submitted by deputies, which allows to bypass consultation processes required in case of governmental legislative proposals, although they are de facto prepared by the executive. In practice, without any justification, several laws were passed without proper vacatio legis. The 'Citizens' Legislation Forum' indicates numerous other forms of the pathology of legislative proceedings which take place at the moment ${ }^{5}$. They create the impression of a real 'emergency state' in legislative processes, which is far from democratic standards and praxeological requirements. It would be difficult to admit that the requirement provided by the preamble of the Polish Constitution "to ensure diligence and efficiency in the work of public bodies" has been met.

\section{Constitutional Changes Since 2015}

As it has been already mentioned, the rank of the symbol of constitutional changes since autumn 2015 should be granted to, above all, the destruction of the Constitutional Tribunal. In fact, this diminishes the imperative of "the supremacy of the Constitution over the political freedom of action of the current parliamentary majority"6. On 25 November 2015, the new ruling majority 'stated the lack of legal force' of five resolutions of the Sejm of the previous term of office - adopted on 8 October 2015 - on the election of judges of the Constitutional Tribunal'. The President of the Republic of Poland refused to take the vow from these judges. On 2 December 2015, the Sejm elected five 'new' judges of the Constitutional Tribunal. This meant that in total 18 judges were elected by the Sejm to the Constitutional Tribunal, although the Constitution provides for 15 judges. The President took the oath from the 'new' judges on 2 December 2015 - the night preceding the

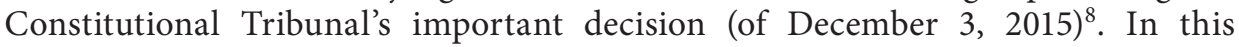
judgment, the Tribunal stated that on 8 October 2015 only two judges out of five were elected on legal basis incompatible with the Constitution. This meant that the three 'newly elected' judges were de facto 'doubles' of lawfully occupied judges' seats. The President of the Constitutional Tribunal did not allow 'doubles' to adjudicate.

On 9 December 2015, the Constitutional Tribunal passed a judgment concerning the amendment of the Constitutional Tribunal Act of 19 November 2015. The ruling majority called this amendment a 'corrective act', but the Constitutional Tribunal found several of its most important provisions unconstitutional. On 22 December 2015 the Sejm again amended the Constitutional Tribunal Act under the guise of 'repairing' the Constitutional Tribunal in a manner inconsistent with the Constitution. The Sejm decided that it shall come into force without vacatio legis. The Constitutional Tribunal ruled on the unconstitutionality of this amendment on

5 See Jakość stanowienia prawa w pierwszym roku rządów Prawa i Sprawiedliwości [Quality of legislation in the first year of the Law and Justice government]. Available: http://www.batory.org.pl/ upload/files/Programy\%20operacyjne/Odpowiedzialne\%20Panstwo/Komunikat\%20z\%20IX\%20 obserwacji.pdf [last viewed 11.02.2019]; Jakość stanowienia prawa w drugim roku rządów Prawa i Sprawiedliwości [Quality of legislation in the second year of the Law and Justice government]. Available: http://www.jawnosc.pl/wp-content/uploads/2017/12/plik.pdf [last viewed 11.02.2019].

6 Garlicki, L. Polskie prawo konstytucyjne [Polish constitutional law]. Warszawa, 2014, p. 344.

7 Resolutions of the Sejm adopted on 8 October 2015 - on the election of judges of the Constitutional Tribunal. The Official Journal of Laws Monitor Polski, items 1131-1135.

8 Decision of the Constitutional Tribunal of 3 December 2015, case No. K 34/15.

9 Decision of the Constitutional Tribunal of 9 December 2015, case No. K 35/15. 
9 March $2016^{10}$ in an extraordinary legal situation. In order to avoid the 'legislative trap' constructed consciously by the Sejm, the Constitutional Tribunal was forced to adjudicate on the basis of art. 195, p. 1 of the Constitution. The Tribunal took as a basis of its adjudication the directly applied provisions of the Constitution and the amendment act excluding some of its provisions which were aimed at 'paralyzing' the Constitutional Tribunal. According to legal requirements, the judgement of 9 March 2016 was to be published in the official journal of laws Dziennik Ustaw. However, the government 'did not recognize' the judgment of the Constitutional Tribunal and decided that there was no obligation to announce it, since - in its opinion - the judgment had no legal legitimacy. The standpoint of the Constitutional Tribunal was definitely supported by such authorities as the Supreme Court and the Supreme Administrative Court.

The subsequent 'response' of the ruling majority to the conflict was the new Act of 22 July 2016 on the Constitutional Tribunal ${ }^{11}$. This act 'continued' the line of constraint against the Constitutional Tribunal. Among others, it 'ordered' the permission to adjudicate by three 'doubles' judges and 'prohibited' the publication of the Court's judgment of 9 March 2016. It contained a number of solutions unduly interfering with the internal organizational system of the Constitutional Tribunal preventing it from performing its duties efficiently and reliably. The Constitutional Tribunal ruled on this law in the judgment of 11 August $2016^{12}$, still in the period of its vacatio legis. The Constitutional Tribunal concluded that as to the merits, the new provisions have been already subject to Tribunal's analyses and decisions of 3 and 9 December 2015 and 9 March 2016. That was because in the Act of 2016 the legislator 'repeated' provisions violating the principle of the tripartite division of power, the principle of the independence of judicial power as well as provisions preventing the Constitutional Tribunal from carrying out reliable and efficient actions. The judgment of the Constitutional Tribunal of 11 August 2016 was also not published by the Prime Minister in the official journal of laws.

Soon afterwards, the politicians of the ruling majority announced the beginning of works on the next act on the Constitutional Tribunal. The entire 'chain' of actions of the ruling majority consistently created instruments aimed at making the Constitutional Tribunal unable to review the constitutionality of its legislative activities. They were based on a political aspiration - against the constitutional principle of the tripartite division of power - to obtain power that is not limited by outside control. Already in 2016, disputes over the Constitutional Tribunal in Poland also resulted in two opinions of the Venice Commission - an advisory body in the legal area in the system of the Council of Europe ${ }^{13}$. They were definitely critical about the 'legislative' obstruction of the Constitutional Tribunal and disregarding its judgments by the Polish government. In particular, the lack of fulfilment of two basic standards of the balance of power - the independence of the judiciary and the position of the Constitutional Tribunal as the final arbitrator in constitutional matters was concluded.

10 Decision of the Constitutional Tribunal of 9 March 2016, case No. K 47/15.

11 Ustawa o Trybunale Konstytucyjnym [Act on the Constitutional Tribunal] (22.07.2016). The Official Journal of Laws Dziennik Ustaw, 2016, item 1157.

12 Decision of the Constitutional Tribunal of 11 August 2016, case No. K 39/16.

13 Opinions of the Constitutional Tribunal of 11 March and 14 October 2016. 
Three new acts and further controversial constitutional practice were the epilogue of the dispute over the Constitutional Tribunal in Poland ${ }^{14}$. Under these acts, the problem of the lack of publication of the three judgments of the Constitutional Tribunal is still unresolved. The government 'does not recognize' them, assuming that it has the power to assess which rulings of the Court are 'lawful' and which are not. The Prosecutor's Office does not see any violation of the binding law in the government's refusal to publish the judgments of the Constitutional Tribunal.

It must be emphasized that the above situation results in a significant drop of institutional trust expressed in the public opinion in regard to the status and role of the Constitutional Tribunal ${ }^{15}$. In 2017, threats and destructive steps covered further areas of the judiciary. The ruling majority with numerous violations of the Constitution changed the statutory status of common courts, the Supreme Court and the National Council of the Judiciary ${ }^{16}$. The parliamentary experience and extra-parliamentary practice in the $8^{\text {th }}$ term of office have proved the weaknesses of the self-defence mechanisms of constitutional order.

\section{Historical Ascendances}

The changes of the constitutional system of a state can provoke a question if they can be perceived against the background of the state's constitutional and political traditions. Such question can also be posed with regard to the constitutional changes in Poland initiated in 2015. However, constitutional traditions are generally not uniform and linear, as they have different currents and meanderings. In Polish legal and constitutional thought, the 'glorious' trend has been created by the Constitution of 3 May $1791^{17}$ and the Constitution of March $1921^{18}$. On the

14 These are currently binding laws: Ustawa o organizacji i trybie postępowania przed Trybunałem Konstytucyjnym [Act on the Organization and Mode of Procedure Before the Constitutional Tribunal] (30.11.2016). The Official Journal of Laws Dziennik Ustaw, 2016, item 2072; Ustawa o statusie sędziów Trybunału Konstytucyjnego [Act on the Status of Judges of the Constitutional Tribunal] (30.11.2016). The Official Journal of Laws Dziennik Ustaw, 2016, item 2073; Przepisy wprowadzające ustawę o organizacji i trybie postępowania przed Trybunałem Konstytucyjnym oraz ustawę o statusie sędziów Trybunału Konstytucyjnego [Provisions introducing the Act on Organization and Procedure before the Constitutional Tribunal and the Act on the Status of Judges of the Constitutional Tribunal] (13.12.2016). Official Journal of Laws Dziennik Ustaw, 2016, item 2074. Available: http://eur-lex.europa.eu/n-lex/legis_pl/prawo_result_en? [last viewed 11.02.2019].

15 In regard to the dispute over the Constitutional Tribunal some parts of the article: Szmyt, A. Destruction..., were used.

16 Grajewski, K. Zmiany statusu prawnego Krajowej Rady Sądownictwa [Changes of the Status of the National Council of Judiciary]. In: Współczesne problemy sądownictwa w Republice Czeskiej i w Rzeczypospolitej Polskiej. Z. Witkowski, J. Jirásek, K. Skotnicki, M. Serowaniec (eds.). Toruń, 2017, pp. 91-122; Szmyt, A. Ocena zgodności z Konstytucją RP projektu nowelizacji ustawy Prawo o ustroju sądów powszechnych [Act on the System of Common Courts]. In: Współczesne problemy sądownictwa w Republice Czeskiej i w Rzeczypospolitej Polskiej. Z. Witkowski, J. Jirásek, K. Skotnicki, M. Serowaniec (eds.). Toruń, 2017, pp. 257-271; Rytel-Warzocha, A., Uziębło, P. National Council of the Judiciary as the guardian of the independence of judges and courts in Poland in the light of recent legislative amendments. In: The International Conference "European Union's History, Culture and Citizenship". Pitesti, 2017, pp. 231-245.

17 Ustawa Rządowa. Z dnia 3-go maja 1791 roku [Governmental Act of 3 May 1791]. Available: http:// libr.sejm.gov.pl/tek01/txt/kpol/1791-r0.html [last viewed 11.02.2019].

18 Konstytucja Rzeczypospolitej Polskiej z 17 marca 1921 r. [Constitution of the Republic of Poland of 17 March 1921]. Available: http://libr.sejm.gov.pl/tek01/txt/kpol/e1921.html [last viewed 11.02.2019]. 
other hand, the Constitution of April $1935^{19}$ and the Constitution of July $1952^{20}$ are not esteemed. The current Constitution of 1997 should be certainly connected although there is no long historical perspective - with the first of these trends. However, the general evaluations are too wide to be fully useful as a tool for the segmented or even short-lasting phenomena. Therefore, it seems more fruitful to refer to strictly defined constitutional structures, which in certain contexts can appear as an argumentation explaining the current reality. There are several threads of this kind.

The Constitution of 3 May 1971 - due to the imminent partition of Poland by the neighbouring countries - in practice had no chance to demonstrate its Enlightenment values. In Polish civic and national thought, however, it has become a powerful myth and symbol of the historical constitutional breakthrough. Subsequent generations recalled its provisions proclaiming that 'all power of human society' comes from 'the will of the Nation' as well as provisions establishing the division of power into legislative, executive and judicial. The provisions of the Constitution, however, 'strengthened' the Parliament (both chambers), exposing the Chamber of Deputies as coming from elections. The preponderance (advantage) of the Sejm was a fairly permanent reference point for many political forces later on. And such is the perception of constitutional issues also by the current ruling forces.

The dominance of the Sejm (despite the division of power as a principle) obtained real significance and was strongly emphasized on the ground of the Constitution of March 1921. At that time the concept of the system of government called 'Sejmocracy' obtained a pejorative meaning. 'Sejmocracy' combined with the instability of the party system of those times (together with the unsatisfactory level of political culture) and permanent tensions between the Parliament and the government gave rise to the coup d'état in May 1926. Its first result was the constitutional strengthening of the government. Democracy somewhat 'anarchized' created an easy temptation to reach for 'disciplining' solutions. However, the 'supremacy' of the Sejm remained in constitutional consciousness as a symbol of democratic solutions. First of all, such an assessment of the March Constitution became a permanent historical legacy. It also became a proof that "despite the programmatic apotheosis of democracy, it failed to protect itself against the enemies of democracy" 21 . The constitutional transformation after 1926 was significantly influenced by the individual's authority - the charismatic legitimization of Józef Piłsudski as the creator of independent Poland.

The changes were continued and the 'breakthrough' was the Constitution of April 1935. It was a total axiological and institutional negation of the previous constitution. It opposed to the principle of the Sejm's supremacy and favoured the strong position of the President who was granted 'uniform and indivisible state power' art. 2 p. 4 of the Constitution), which meant the rejection of the principle of the division of power. The Sejm - like other state organs - was subjected to the

19 Konstytucja Rzeczypospolitej Polskiej z 23 kwietnia 1935 [Constitution of the Republic of Poland of 23 April 1935]. Available: http://libr.sejm.gov.pl/tek01/txt/kpol/e1935-spis.html [last viewed 11.02.2019].

20 Konstytucja Polskiej Republiki Ludowej z 22 lipca 1952 r. [Constitution of the Polish People's Republic. Adopted by the Legislative Diet on July 22, 1952]. Available: http://libr.sejm.gov.pl/tek01/ txt/kpol/e1976.html [last viewed 11.02.2019].

21 Szymanek, J. Tradycje konstytucyjne. Szkice o roli ustawy zasadniczej w społeczeństwie demokratycznym [Constitutional traditions. Sketches on the role of the basic law in a democratic society]. Warszawa, 2006, p. 132. 
'supremacy' of the President, who was responsible only before the 'God and history' (art. 2, p. 2). These solutions accompanied the axiological mission of the 'sanitation' of political and constitutional system by the ruling camp which was hostile to political pluralism. The personalized 'Caesarism' was based on the personal authority of a specific individual. The death of Marshal Piłsudski caused in practice the decomposition of this political system which was ended by the outbreak of war in 1939. In the historical tradition, the Constitution of 1935 became a symbol of breaking with the canon of constitutional principles respected in liberal-democratic regimes.

The next Polish Constitution of 1952 received very negative assessments. In fact, it was a façade legal act, whose axiology and solutions did not coincide with reality. It petrified the rejection of political pluralism and previously established understanding of democracy. Real decision-making mechanisms were not related to legal instruments. The centres of political and constitutional decisions functioned autonomously in relation to constitutional structures. At the same time, the Constitution of 1952 introduced the principle of the unity of power and the superior position of the Parliament. The gap between the normative and political layer and the earlier constitutional traditions gave the impression that the meaning of the Constitution as an axiological foundation was non-existent ${ }^{22}$.

\section{Summary}

The above review - signalizing some political and constitutional aspects - makes us realize that in Polish constitutional tradition we can indicate elements to which more or less clearly - the current processes of constitutional changes can be referred to. The echoes of past solutions are in a sense 'woven into' today's tendencies viewed against the background of the indicated elements of the constitutional tradition.

In particular, it is symptomatic that the ruling majority emphasizes that it is legitimized by the electoral process. They point the Nation as a sovereign who created the representative body and gave the parliamentary majority a mandate to carry out reforms. However, emphasizing the role of the sovereign, the role of the representative body, the electoral investment for reforms is a considerable simplification at least for two reasons. The ruling camp obtained a parliamentary majority in elections, allowing it to form its own government and pass ordinary laws. However, they did not get a 2/3 majority of votes, the so-called 'constitutional' majority necessary for the legal amendment of the Constitution (art. 235 p. 4). This means that ordinary legislation must fall within the framework set out in the current Constitution, not being permitted to contradict it. By an electoral act, the sovereign did not authorize the parliamentary majority to pass laws incompatible with the Constitution. The claims about mandate obtained from the Sovereign are, in these circumstances, a false constitutional rhetoric aimed at legitimizing anticonstitutional activities. The feature of this rhetoric is - in addition - 'reversing' the meanings of concepts anchored in the tradition of constitutional democracy, in an unworthy manner that lowers the standards of legal and constitutional decency. This is a manifestation of the abuse of constitutional principles. Appealing to a democratic mandate does not legitimize the 'special' role of the Parliament in relations to the judiciary. Their mutual relations are defined by the constitutional

22 See Borecki, P. Geneza Konstytucji PRL z 22 lipca 1952 r. [The origins of the Constitution of the Polish People's Republic of 22 July 1952]. Przeglad Sejmowy, No. 5, 2007, pp. 75-87. 
principles of the division of power and the independence of courts and judges. Without amending the Constitution, the activities of legislative and executive bodies that defy these principles have no legal legitimacy. The element of 'democratism' of the legislative power in a simplified manner is abused in media campaigns, especially those directed against the 'third power'. Instrumentally, however, it is based on the elements of political and legal tradition that are deeply rooted in Poland.

The systemic decomposition of current constitutional processes is expressed precisely in locating the 'political decision-making centre' outside the Parliament, and even outside the structures of the state apparatus. The current constitutional practice shows that political decisions are made by the leader of the main party of the ruling camp, who manages his party in an autocratic manner. In the formal sense, he is 'only' an ordinary deputy who does not hold any prominent state function. We can observe the programmatic acceptance of the 'charismatic' legitimization of the role of the political leader and the instrumental and executive role of state organs. The 'personal' governments in this sense are not new in Polish constitutional and political traditions. They are favoured by both the experience of the facade of constitutional solutions and the populist ideology of the leader of the 'good change' camp.

The current political and constitutional processes presented above certainly do not belong to the glorious current of Polish traditions. In their assumptions they are de facto hostile to the Constitution in force $^{23}$. De iure they are a distorted, manipulative interpretation of the Constitution. They are a manifestation of legal nihilism and a low level of political culture.

By law, the foundations of the rule of law, division of powers and judicial independence have been violated. Through legislative changes the Public Prosecutor's Office was subordinated to executive power and the Minister of Justice obtained a significant influence on the functioning of the common judiciary. The present changes bring forth a question, in the light of which Polish constitutional traditions, if any, they can be perceived. There are several threads. The practice of referring to 'supraposition' of the Parliament fits into the long-term tradition of the 'priority' role of the representative bodies - still from the First Republic, then the March Constitution of 1921, and finally the times of the People's Republic of Poland with the constitutional principle of unity (instead of division) of power and the superior position of the unicameral Sejm. The First Republic had a weak position of the judiciary, and in the period of the Partitions (loss of independence) the general lack of authorities imposed by neighbouring states was present. During the Second Republic (interwar period), the democratic restrictions - after the May 1926 coup were caused by the appeal of the ruling camp to charismatic legitimization of the independence father Józef Piłsudski. A reference to this part of interwar history is an important motive for the ideology of the leader of the current ruling majority. It is supplemented by the concept of the 'political decision-making centre' of the state, located outside the state apparatus, anchored in the facade of constitutional solutions from the period of the socialist system. This facilitates political control, without the support of democratic procedures. In the name of the effectiveness of

23 The title of the contribution of M. Wyrzykowski is symptomatic: Wyrzykowski, M. "Wrogie przyjęcie" porządku konstytucyjnego ["Hostile takeover' of the constitutional order"]. In: Wyzwania dla ochrony konkurencji i regulacji rynku. Księga jubileuszowa dedykowana Profesorowi Tadeuszowi Skocznemu. Warszawa: Wolters Kluwer, 2017, pp. 831-853. 
propagandist 'good' governments, it is easy to carry out measures to strengthen the executive, which was also carried out under the rule of the 1935 Constitution and in the times of the socialist system.

\section{Sources}

\section{Bibliography}

1. Borecki, P. Geneza Konstytucji PRL z 22 lipca 1952 r. [The origins of the Constitution of the Polish People's Republic of 22 July 1952]. Przeglad Sejmowy, No. 5, 2007, pp. 75-87.

2. Garlicki, L. Polskie prawo konstytucyjne [Polish constitutional law]. Warszawa, 2014.

3. Grajewski, K. Zmiany statusu prawnego Krajowej Rady Sądownictwa [Changes of the status of the National Council of Judiciary]. In: Współczesne problemy sądownictwa w Republice Czeskiej i w Rzeczypospolitej Polskiej. Z. Witkowski, J. Jirásek, K. Skotnicki, M. Serowaniec (eds.). Toruń, 2017, pp. 91-122.

4. Grzybowski, M. (ed.). System rządów Rzeczypospolitej Polskiej. Założenia konstytucyjne a praktyka ustrojowa [Constitutional system of the Republic of Poland. Constitutional assumptions and constitutional practice]. Warszawa, 2006.

5. Jarosz, Z. (ed.) Parlament. Model konstytucyjny a praktyka ustrojowa [Parliament. Constitutional model and the constitutional practice]. Warszawa 2006.

6. Kuciński, J., Wołpiuk, W. J. Zasady ustroju politycznego państwa w Konstytucji Rzeczypospolitej Polskiej z 1997 roku [The principles of the constitutional system in the Constitution of the Republic of Poland of 1997]. Warszawa, 2012.

7. Rytel-Warzocha, A., Szmyt, A. The new law of 2016 on the Constitutional Tribunal in Poland. Annales Universitatis Apulensis. Series Jurisprudentia, No. 19, 2016, pp. 263-290.

8. Rytel-Warzocha, A., Uziębło, P. National Council of the Judiciary as the guardian of the independence of judges and courts in Poland in the light of recent legislative amendments. In: The International Conference "European Union's History, Culture and Citizenship". Pitesti, 2017, pp. 231-245.

9. Sokolewicz, W. (ed.). Zasady podstawowe polskiej Konstytucji [The basic principles of the Constitution of the Republic of Poland]. Warszawa 1998.

10. Szmyt, A. Zakres i treść Konstytucji RP z $1997 \mathrm{r}$. [The scope and content of the Constitution of the Republic of Poland of 1997]. "Zeszyty Prawnicze” Biura Analiz Sejmowych. Warszawa, No. 4, 2012, pp. 229-234.

11. Szmyt, A. Destruction of the Constitutional Tribunal in Poland in the Light of Opinions of the Venice Commision. In: Giustizia e Constitutione agli albori del XXI Secolo, a cura die L. Mazetti e E. Ferioli, Bologna: Benomo Editore, 2017, tomo 1, pp. 641-656.

12. Szmyt, A. Ocena zgodności z Konstytucją RP projektu nowelizacji ustawy - Prawo o ustroju sądów powszechnych [Act on the system of common courts]. In: Współczesne problemy sądownictwa w Republice Czeskiej i w Rzeczypospolitej Polskiej. Z. Witkowski, J. Jirásek, K. Skotnicki, M. Serowaniec (eds.). Toruń, 2017, pp. 257-271.

13. Szymanek, J. Tradycje konstytucyjne. Szkice o roli ustawy zasadniczej w społeczeństwie demokratycznym [Constitutional traditions. Sketches on the role of the basic law in a democratic society]. Warszawa, 2006.

14. Wyrzykowski, M. "Wrogie przyjęcie" porządku konstytucyjnego ["Hostile takeover' of the constitutional order"]. In: Wyzwania dla ochrony konkurencji i regulacji rynku. Księga jubileuszowa dedykowana Profesorowi Tadeuszowi Skocznemu. Warszawa: Wolters Kluwer, 2017, pp. 831-853.

\section{Normative Acts}

1. Konstytucja Polskiej Republiki Ludowej z 22 lipca 1952 r. [Constitution of the Polish People's Republic. Adopted by the Legislative Diet on July 22, 1952]. Available: http://libr.sejm.gov.pl/tek01/ txt/kpol/e1976.html [last viewed 11.02.2019].

2. Konstytucja Rzeczypospolitej Polskiej [Constitution of the Republic of Poland] (02.04.2007). The Official Journal of Laws Dziennik Ustaw, No. 78, 1997.

3. Konstytucja Rzeczypospolitej Polskiej z 17 marca $1921 \mathrm{r}$. [Constitution of the Republic of Poland of 17 March 1921]. Available: http://libr.sejm.gov.pl/tek01/txt/kpol/e1921.html [last viewed 11.02.2019].

4. Konstytucja Rzeczypospolitej Polskiej z 23 kwietnia 1935 [Constitution of the Republic of Poland of 23 April 1935]. Available: http://libr.sejm.gov.pl/tek01/txt/kpol/e1935-spis.html [last viewed 11.02.2019]. 
5. Przepisy wprowadzające ustawę o organizacji i trybie postępowania przed Trybunałem Konstytucyjnym oraz ustawę o statusie sędziów Trybunału Konstytucyjnego [Provisions introducing the Act on Organization and Procedure before the Constitutional Tribunal and the Act on the Status of Judges of the Constitutional Tribunal] (13.12.2016). Official Journal of Laws Dziennik Ustaw, 2016, item 2074. Available: http://eur-lex.europa.eu/n-lex/legis_pl/prawo_result_ en? [last viewed 11.02.2019].

6. Ustawa o organizacji i trybie postępowania przed Trybunałem Konstytucyjnym [Act on the Organization and Mode of Procedure Before the Constitutional Tribunal] (30.11.2016). The Official Journal of Laws Dziennik Ustaw, 2016, item 2072.

7. Ustawa o statusie sędziów Trybunału Konstytucyjnego [Act on the Status of Judges of the Constitutional Tribunal] (30.11.2016). The Official Journal of Laws Dziennik Ustaw, 2016, item 2073.

8. Ustawa o Trybunale Konstytucyjnym [Act on the Constitutional Tribunal] (22.07.2016). The Official Journal of Laws Dziennik Ustaw, 2016, item 1157.

9. Ustawa Rządowa. Z dnia 3-go maja 1791 roku [Governmental Act of 3 May 1791]. Available: http:// libr.sejm.gov.pl/tek01/txt/kpol/1791-r0.html [last viewed 11.02.2019].

\section{Case Law}

1. Decision of the Constitutional Tribunal of 3 December 2015, case No. K 34/15.

2. Decision of the Constitutional Tribunal of 9 December 2015, case No. K 35/15.

3. Decision of the Constitutional Tribunal of 9 March 2016, case No. K 47/15.

4. Decision of the Constitutional Tribunal of 11 August 2016, case No. K 39/16.

\section{Other Sources}

1. Jakość stanowienia prawa w drugim roku rządów Prawa i Sprawiedliwości [Quality of legislation in the second year of the Law and Justice government]. Available: http://www.jawnosc.pl/wp-content/ uploads/2017/12/plik.pdf [last viewed 11.02.2019].

2. Jakość stanowienia prawa w pierwszym roku rządów Prawa i Sprawiedliwości [Quality of legislation in the first year of the Law and Justice government]. Available: http://www.batory.org.pl/upload/files/ Programy\%20operacyjne/Odpowiedzialne\%20Panstwo/Komunikat\%20z\%20IX\%20obserwacji.pdf [last viewed 11.02.2019]. 


\title{
Avoidance of Double Taxation in the Area of Income Tax in Latvia
}

\author{
Dr. iur. Jānis Lazdinš \\ Faculty of Law, University of Latvia \\ Professor at the Department of Legal Theory and History \\ E-mail: Janis.Lazdins@lu.Iv \\ Dr. oec. Kārlis Ketners \\ BA School for Business and Finance \\ Professor at the Department of Finance and Economics \\ E-mail: Karlis.Ketners@ba.Iv
}

\begin{abstract}
The article is dedicated to the experience of preventing double taxation in the Republic of Latvia, the area of income tax. This topic is made relevant by the tax reform implemented in 2018. Although the payment of income tax has been conceptually changed, the authors propose the thesis regarding a constant approach to prevention of double taxation, based on recommendations by the Organisation for Economic Co-operation and Development (hereinafter - OECD). In the framework of income tax reform, additional requirements have been integrated into regulatory enactments to eliminate the possibility of tax evasion.
\end{abstract}

Keywords: tax law, direct tax, indirect tax, double taxation, avoidance of double taxation, resident for taxation purposes.

\section{Contents}

Introduction . . . . . . . . . . . . . . . . . . . . . . . . . . . . . . . . . . . . 69

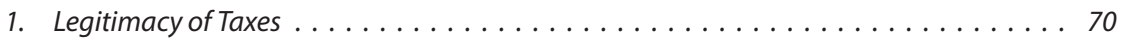

2. Avoidance of Double Taxation by Residency Tiebreaker Method . . . . . . . . . . . . 73

3. Avoidance of Double Taxation by Using Relief and Credit Methods . . . . . . . . . . 76

3.1. Avoidance of Double Taxation in Case of Applying PIT . . . . . . . . . . 76

3.1.1. Avoidance of Double Taxation with Relief Method . . . . . . . . . . 76

3.1.2. Avoidance of Double Taxation by Credit Method . . . . . . . . . . . . . 77

3.2. Avoidance of Double Taxation in Case of Applying Enterprise Income Tax . . . . 78

3.2.1. Avoidance of Double Taxation by Relief and Credit Method . . . . . . . . 78

3.2.2. The Case of Transfer Pricing . . . . . . . . . . . . . . . . 80

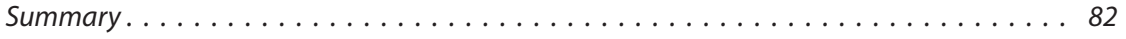

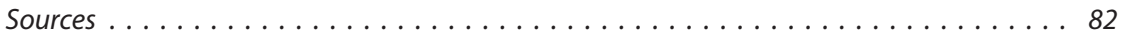

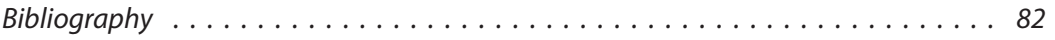

Case Law............................... 84 


\section{Introduction}

The state is sovereign in its right to legislate, which includes the right to levy and collect taxes within its jurisdiction. Double taxation occurs if more than one state claims the income of the same person within the same taxation period. ${ }^{1}$ To put it differently: international double taxation is linked to the identity of the subject of taxes (payer), the object of taxes (source of income and income), subjects being within various tax jurisdictions (different definitions for determining the status of a resident for taxation purposes), simultaneous levying of taxes (various rules on applying the source or the income of the country of residence), different methods and rules on determining the taxable object. ${ }^{2}$

Apart from levying taxes on residents, states usually apply taxes also to transactions, which have been conducted in the respective jurisdiction or income, the origins (source) of which are in the respective jurisdiction. Thus, although the state of income origin may not be the country of residence of the resident for taxation purposes, the tax commitments remain also in the state of income origin / source. ${ }^{3}$

If the tax burden is disproportionally high, double taxation becomes a problem for the taxpayer and also for the state's competitiveness. Of course, a rhetorical question may be apposite - what kind of tax burden should be deemed to be disproportionally high? One can assume that demanding to pay more than $50 \%$ of a person's total income in taxes is disproportional. ${ }^{4}$ For instance, if, in the Republic of Latvia, the rate 20, 23 and $31.40 \%{ }^{5}$ is applied to a natural person's income of the taxation year and in the Republic of Austria the same income was applied 25-50, $55 \%$ rate $^{6}$ then, obviously, demanding the taxpayer to meet the tax commitments simultaneously in both countries in accordance with the principle of taxing worldwide income would be disproportional.

To avoid double consumption (indirect) taxation in cross-border transactions, the indirect taxes are aligned (harmonised) in the Member States of the European Union (hereinafter - the EU). ${ }^{7}$ The EU Member States have been granted

1 Frotscher, G. Internationales Steuerrecht. 4, völlig überarbeitete Auflage. München: Verlag C. H. Beck, 2015, S. 3.

2 Ketners, K. Nodokḷi un nodokḷu plānošanas principi [Tax and principles of tax planning]. Rīga: SIA “Tehnoinform Latvia”, 2018, pp. 154-156.

3 Ketners, K., Pētersone, M. Eiropas Savienības nodokḷu politika [European Union tax policy]. Rìga: RTU Press, 2014, pp. 47-50; Vogel, K. et al. Klaus Vogel on Double Taxation Conventions. A Commentary to the OECD-, UN- and US Model Conventions for the Avoidance of Double Taxation on Income and Capital. With Particular Reference to German Treaty Practice. $3^{\text {rd }}$ edition. London: Kluwer Law International Ltd., 1995, p. 9.

4 Frotscher, G. Internationales Steuerrecht. 4., völlig überarbeitete Auflage. München: Verlag C. H. Beck, 2015, S. 3.

5 Par iedzīvotāju ienākuma nodokli [On Personal Income Tax] (11.05.1993), art. 15.2. Available: https://likumi.lv/doc.php?id=56880 [last viewed 20.04.2019].

6 Für Einkommensteile über eine Million Euro beträgt der Steuersatz in den Kalenderjahren 2016 bis 2020 55\% [In Austria, in 2016-2020 55\% tax rate is applied to income exceeding 1 million euros]. Über die Besteuerung des Einkommens natürlicher Personen (07.07.1988), art. 33. Available: https:// www.ris.bka.gv.at/GeltendeFassung.wxe?Abfrage $=$ Bundesnormen \&Gesetzesnummer $=10004570$ [last viewed 20.04.2019].

7 Lìgums par Eiropas Savienỉbas darbību [The Treaty on the Functioning of the European Union], art. 113. Available: https:/eur-lex.europa.eu/legal-content/LV/TXT/?uri=CELEX\%3A12012E\% 2FTXT [last viewed 20.04.2019]. 
considerable discretion in the field of direct taxes. ${ }^{8}$ Harmonisation of direct taxes in the EU can be discussed only conditionally, and, thus, the EU Member States in many ways shoulder the avoidance of double taxation. ${ }^{9}$

On 1 July 2016, Latvia officially became the $35^{\text {th }}$ Member State of OECD. ${ }^{10}$ Although even prior to this Latvia, as regards avoidance of double taxation, followed the OECD recommendations, the accession to this organisation increases Latvia's responsibility in this respect.

The aim of the article is to examine the experience in the avoidance of double taxation in the area of income taxes in the Republic of Latvia, inter alia, the established legitimacy of taxes in the judicature of the Constitutional Court of the Republic of Latvia (hereinafter - the Constitutional Court) and in the case law of the Latvian courts.

\section{Legitimacy of Taxes}

The Satversme [Constitution] of the Republic of Latvia (hereinafter - the Satversme) provides that the property right may be restricted only on the basis of law. ${ }^{11}$ In Latvia, all taxation laws have been established on the basis of law. ${ }^{12}$ Thus, formally, the requirements of the Satversme have been met. However, the Satversme does not provide an answer to the question, whether the restriction on fundamental rights, imposed by particular taxation laws, is proportionate and reaches the legitimate aim in a democratic society. The Constitutional Court has analysed the compliance of tax law with the Satversme in a number of judgements.

The Constitutional Court notes that " $\mathrm{t}] \mathrm{he}$ state, in determining and implementing its taxation policy, enjoys broad discretion."13 "It comprises the right to choose the tax rates and categories of persons for whom these are envisaged, as well as the right to define the details of the respective regulation." 14 "The

8 See for instance, Margaret Block vs. Finanzamt Kaufbeuren, No. C-67/08, para. 31. Available: http://curia.europa.eu/juris/document/document.jsf;jsessionid=631055E95D4364261C819C062 E8BCF81 ?text $=$ \&docid $=76237 \&$ pageIndex $=0 \&$ doclang $=$ LV\&mode $=1$ st\&dir $=$ \&occ $=$ first $\&$ part $=1$ \&cid=12000413 [last viewed 20.04.2019]; Marks \& Spencer plc. vs. David Halsey (Her Majesty's Inspector of Taxes), No. C-446/03, para. 29. Available: http://curia.europa.eu/juris/document/ document.jsf?text $=$ \&docid $=57067 \&$ pageIndex=0\&doclang=LV\&mode $=$ lst \&dir $=$ \&occ $=$ first \&part $=1 \&$ cid=12001880 [last viewed 20.04.2019] or Frotscher, G. Internationales Steuerrecht. 4., völlig überarbeitete Auflage. München: Verlag C. H. Beck, 2015, S. 102; Lazdiņš, J., Ketners, K. The Effect of Court Rulings on the Dynamics of the Latvian Tax Law. Journal of the University of Latvia. Law, No. 5, 2013, p. 31.

9 Haase, F. Internationales und Europisches Steuerrecht. 4., neu bearbeitete Auflage. Heidelberg, München, Landsberg, Frechen, Hamburg: C. F. Müller, 2014, S. 17-18.

10 Līgums par Latvijas Republikas pievienošanās konvencijai par Ekonomiskās sadarbības un attīstības organizāciju nosacījumiem [Agreement on the terms of accession of the Republic of Latvia to the convention on the Organisation for Economic Co-operation and Development] (29.04.2016). Available: https://ikumi.lv/ta/lv/starptautiskie-ligumi/id/1249 [last viewed 20.04.2019].

11 Latvijas Republikas Satversme [The Constitution of the Republic of Latvia], art. 105 (15.02.1922). Available: https://likumi.lv/doc.php?mode=DOC\&id=57980 [last viewed 20.04.2019].

12 Par nodokḷiem un nodevām [On Taxes and Duties], art. 8 (02.02.1995). Available: https://likumi.lv/ doc.php?id=33946 [last viewed 20.04.2019].

13 Latvijas Republikas Satversmes tiesas 2011. gada 20. maija spriedums lietā Nr. 2010-70-01 [Judgement of 20 May 2011 by the Constitutional Court of the Republic of Latvia in case No. 201070-01], para. 9. Available: http://www.satv.tiesa.gov.lv/wp-content/uploads/2016/02/2010-70-01_ Spriedums.pdf [last viewed 20.04.2019].

14 Latvijas Republikas Satversmes tiesas 2015. gada 25. marta spriedums lietā Nr. 2014-11-0103 [Judgement of 25 March 2015 by the Constitutional Court of the Republic of Latvia in case No. 2014- 
legislator's choice, which tax would be necessary, is a matter of expedience". 15 "In examining the limits of the legislator's discretion with respect to determining a tax for a particular object, it should be taken into account that the Satversme expressis verbis authorises the legislator to adopt the state budget, thus, to determine the revenue and the expenditure of the state. The Satversme authorises the legislator to implement such fiscal policy that ensures the necessary income for the state."16

In specifying the legitimacy of restricting the property right, the Constitutional Court, referring to the established judicature of the Federal Constitutional Court of Germany, notes that “a person's fundamental right to property is not violated if the State imposes upon a person public law obligations to make monetary payments, which are not an excessive burned for this person and do not significantly influence his financial situation. ${ }^{17 "}$ The Constitutional Court has "borrowed" findings of similar content also from the Constitutional Court of the Republic of Lithuania and the Constitutional Court of the Kingdom of Belgium. ${ }^{18}$ The final conclusion derived from this us that " in a democratic state governed by the rule of law, the right to property is not absolute"19. Thus, the Constitutional Court has not identified a contradiction with the Satversme in the obligation to pay taxes.

Solidarity Tax Law ${ }^{20}$, adopted on 11 November 2015, which was perceived controversially by the society, and the double constitutional review of some norms of the law turned into a certain exception. ${ }^{21}$

The solidarity tax was introduced at the moment when a natural person's income was levied the personal income tax in accordance with a proportional rate $(23 \%){ }^{22}$ In Latvia, salaried employees and performers of economic activities as self-employed persons are subject to state mandatory social insurance contributions (hereinafter - SMSIC). The so-called contribution 'ceiling' has been set for SMSIC, i.e., contributions are discontinued upon reaching the maximum,

11-0103], para. 20. Available: http://www.satv.tiesa.gov.lv/wp-content/uploads/2016/02/2014-110103_Spriedums.pdf [last viewed 20.04.2019].

15 Latvijas Republikas Satversmes tiesas 2017. gada 19. oktobra spriedums lietā Nr. 2016-14-01 [Judgement of 19 October 2017 by the Constitutional Court of the Republic of Latvia in case No. 2016-14-01], para. 23. Available: http://www.satv.tiesa.gov.lv/web/viewer.html?file=http://www. satv.tiesa.gov.lv/wp- [last viewed 20.04.2019].

16 Constitutional Court of the Republic of Latvia, Judgment on case No. 2014-11-0103, para. 20.

17 Latvijas Republikas Satversmes tiesas 2010. gada 6. decembra spriedums lietā Nr. 2010-25-01 [Judgement of 6 December 2010 by the Constitutional Court of the Republic of Latvia in case No. 2010-25-01], para. 10. Available: http://www.satv.tiesa.gov.lv/web/viewer.html?file= http://www.satv.tiesa.gov.lv/wp-content/uploads/2016/02/2010-25-01_Spriedums.pdf\#search= [last viewed 20.04.2019].

18 Ibid.

19 Latvijas Republikas Satversmes tiesas 2010. gada 19. jūnija spriedums lietā Nr. 2010-02-01 [Judgement of 9 June 2010 by the Constitutional Court of the Republic of Latvia in case No. 201002-01], para. 6. Available: http://www.satv.tiesa.gov.lv/wp-content/uploads/2016/02/2010-02-01_ Spriedums.pdf [last viewed 20.04.2019].

20 Solidaritātes nodokḷa likums [Solidarity Tax Law] (30.11.2015). Available: https://likumi.lv/ta/ id/278636-solidaritates-nodokla-likums [last viewed 20.04.2019].

21 Constitutional Court of the Republic of Latvia, Judgment on case No. 2016-14-01, para. 2; Latvijas Republikas Satversmes tiesas 2017. gada 16. novembra spriedums lietā Nr. 2016-16-01 [Judgement of 16 November 2017 by the Constitutional Court of the Republic of Latvia in case No. 2016-16-01], para. 3. Available: http://www.satv.tiesa.gov.lv/web/viewer.html?file=http://www.satv.tiesa.gov.lv/ wp-content/uploads/2017/11/2016-16-01_Spriedums.pdf\#search= [last viewed 20.04.2019].

22 See On Personal Income Tax, historical consolidated version of the law 01.07.-02.12.2015, art. 15. Available: https://likumi.lv/doc.php?id=56880 [last viewed 20.04.2019]. 
to which SMSIC is applied, which is determined by the state. ${ }^{23}$ Hence, persons with high income participated in social solidarity, proportionally to their income, disproportionally less than other salaried employees or self-employed performers of economic activities.

SMSIC, which exceeded the SMSIC 'ceiling'24 were defined as the object of solidarity tax. The tax payment was transferred into the basic state budget. At the moment of its adoption, the solidarity tax could be treated as a specific income tax $\mathrm{x}^{25}$ with the aim of decreasing the regression of taxes. ${ }^{26}$ Levelling of the tax burden between the various groups of taxpayers was also compatible with the principle of a socially responsible state defined in the Satversme. ${ }^{27}$

SMSIC rate is not the same for all those, who make social contributions. It depends on the person's employment, age and other circumstances or the social risks that the payer could be subject to. For example, a person, who has reached the retirement age, is not insured against unemployment since he cannot lose the source of income - pension. ${ }^{28}$ If differentiation in the case of SMSIC can be legitimately justified the same could not apply to the solidarity tax as an income tax. Therefore, the Constitutional Court, validly, recognised as being incompatible with the principle of equality enshrined in the Satversme not the solidarity tax as such but only the different tax rates for groups of solidarity tax payers. ${ }^{29}$

After the constitutional complaints were submitted but before the judgements of the Constitutional Court in the solidarity tax cases were pronounced, significant amendments were introduced to Solidarity Tax Law, transforming the solidarity tax into a hybrid tax; i.e., the solidarity tax is simultaneously a payment of income tax and social insurance contribution. ${ }^{30}$

On 1 January 2018, significant amendments to the law "On Personal Income Tax" (hereinafter - PIT) entered into force. Personal income is no longer subject to the proportional tax rate (23\%); instead, a progressive tax rate is introduced (20, 23 and 31.4\%). At present, regression in paying taxes can be discussed only up to a point, and paying of the solidarity tax probably does not meet the initial aim of decreasing regression in paying taxes.

The Constitutional Court's findings in the tax cases probably should not be viewed as an innovation. Regretfully, the Constitutional Court, just like the Latvian legal science, is silent about the inadmissibility of double taxation or the possible solutions to it. However, the Constitutional Court has recognised the

23 At the moment of introducing Solidarity Tax Law, the 'ceiling' of SMSIC contributions in the taxation year was 48600 euro (in 2018, the maximum amount of SNSIC has reached 55000 euro). See Par valsts sociālās apdrošināšanas obligāto un brīvprātīgo iemaksu objekta minimālo un maksimālo apmēru [Regulations Regarding the Minimum and Maximum Amount of the Object of Mandatory and Voluntary Contributions of State Social Insurance], art. 5 (17.12.2013). Available: https://likumi.lv/doc.php?id=263238 [last viewed 20.04.2019].

24 SMSIC are paid both by the employer and the employee. Thus, the payers of solidarity tax also are employers and employees.

25 Constitutional Court of the Republic of Latvia, Judgment in case No. 2016-14-01, para. 19.3.

26 Solidarity Tax Law, art. 2.1.

27 See The Constitution of the Republic of Latvia, Preamble.

28 Par valsts sociālo apdrošināšanu [On State Social Insurance], art. 6.2 (01.10.1997). Available: https://likumi.lv/doc.php?id=45466 [last viewed 20.04.2019].

29 Constitutional Court of the Republic of Latvia, Judgment in case No. 2016-14-01, para. 27.3.

30 Solidarity Tax Law, qrt. 9. 
legitimacy of Latvian taxes (except the different tax rates of Solidarity Tax Law ${ }^{31}$ ) and, consequently, also the compliance of the tax conventions that have entered into force and the methods for avoiding double taxation established in the national regulatory enactments with the Satversme.

\section{Avoidance of Double Taxation by Residency Tiebreaker Method}

The residency tiebreaker method is an internationally recognised method for avoiding double taxation. The residency tiebreaker is regulated by the national legislation and the tax conventions on the international level. In this respect, Latvia is not an exception. ${ }^{32}$ Hence, the national criteria for determining residency for taxation purposes are supplemented by the concluded tax conventions. The priority of international treaties has been established in Latvia. If the norms of international treaties ratified by the Saeima (the Parliament) collide with the national legislation then the rules of the international treaty are applied. ${ }^{33}$

Pursuant to the law "On Taxes and Duties" (hereinafter - TaD), taxes and duties (hereinafter - the tax) are paid by the domestic taxpayers (residents) and foreign taxpayers (non-residents). ${ }^{34}$ The law recognises as taxpayers natural persons, legal persons and associations (groups) of these persons. Residents pay taxes from worldwide income, whereas non-residents - from the income gained in Latvia. The circle of payers of a particular tax is defined in each particular tax law.

In accordance with $\mathrm{TaD}$ article 14, a natural person is considered to be a resident of Latvia if:

1) his declared place of residence is in the Republic of Latvia; or

2) he stays in the Republic of Latvia for 183 days or longer during any 12-month period beginning or ending in a taxation year; or

3) he is a Latvian citizen, who is employed in a foreign country by the government of the Republic of Latvia. ${ }^{35}$

Instead of the term 'declared place of residence' used in the national legislation, the term 'permanent place of residence' is used in tax conventions. In Latvia, the personal income tax is split between the state budget and the local governments' budgets. In accordance with the declared place of residence, the largest part of PIT is transferred into the budget of the local government, where the place of residence is declared. ${ }^{36}$ Of course, from the perspective of international tax law, it matters only whether Latvia is or is not a natural person's permanent place of residence.

The criterion of 183 days does not apply to the particular taxation year. A person's physical staying for 183 days or longer within the period of 12 months, which begins or ends in a taxation year, is essential. The date of reference for

31 Enforcing the Constitutional Court's judgement, since 1 January 2019 the solidarity tax rate for all taxpayers is 25.50 per cent. See Grozījumi Solidaritātes nodokḷa likumā [Amendments to Solidarity Tax Law] (20.12.2018). Available: https://likumi.lv/ta/id/304032-grozijumi-solidaritates-nodoklalikuma [last viewed 20.04.2019].

32 Augstākās tiesas 2016. gada 12. decembra spriedums lietā Nr. SKA-739/2016 (A420479613) [Judgement of 12 December 2016 by the Supreme Court in case No. SKA-739/2016 (A420479613)], para. 8. Available: https://manas.tiesas.lv/eTiesasMvc/lv/nolemumi; file://C:/Users/LU\%20JF/ Downloads/Anonimizets_nolemums_291360.pdf [last viewed 20.04.2019].

33 On Taxes and Duties, art. 7.1; On Personal Income Tax, art. 24.

34 On Personal Income Tax, art. 14.1.

35 On Taxes and Duties, art. 14.2-3.

36 In recent years, this proportion has been set as $80 \%$ against $20 \%$, in favour of the local governments' budgets. 
acquiring the resident's status is the first arrival of a natural person to Latvia in the respective period. After leaving Latvia, in the presence of closer ties with the foreign country, the natural person is no longer considered as being a resident of Latvia. $\mathrm{TaD}$ recognises only three criteria as closer ties or a foreign centre of vital interests:

1) a natural person owns property in the foreign country;

2) the family is residing in the foreign country;

3) the person makes social insurance contributions in the foreign country. ${ }^{37}$

In view of the legal construction of $\mathrm{TaD}$ article 14 , it can be concluded that the determination of the residency of a natural person cannot be based solely on the territorial principle. Property, family or social insurance contributions made abroad are recognised as essential criteria. The criteria for residence tiebreaker are supplemented by the tax conventions that Latvia has entered into. ${ }^{38}$

Tax conventions single out five criteria for determining the residence status of a natural person. ${ }^{39}$ For example, from the Convention between the government of the Republic of Latvia and the government of the United Kingdom of Great Britain and Northern Ireland for the avoidance of double taxation and the prevention of fiscal evasion with respect to taxes on income and capital gains ${ }^{40}$, apart from the criterion of permanent life, described above [1)] four other criteria are singled out:

2) with a permanent place of residence in both states - parties to the contract, a natural person is considered to be resident of that country, with which it is connected with the so-called 'centre of vital interests' or closer personal or economic ties.

In the tax theory, closer personal and economic ties are understood as a person's intention to settle for living in the respective state for a prolonged period rather than for a relatively short period of time (for example, while travelling or studying).

37 On Taxes and Duties, art. 14.3.

38 Eiropas nodokḷi Latvijā [European Taxes in Latvia]. Rīga: Latvijas Ekonomists, Ernst \& Young, 2004, pp. 133-135.

39 See for instance Par Latvijas Republikas un Amerikas Savienoto Valstu konvenciju par nodokḷu dubultās uzlikšanas un nodokḷu nemaksāšanas novēršanu attiecībā uz ienākuma nodokḷiem [Convention between the Republic of Latvia and the United States of America for the Avoidance of Double Taxation and the Prevention of Fiscal Evasion with Respect to Taxes on Income], art. 4.4 (14.05.1998). Available: https://likumi.lv/doc.php?id=48313 [last viewed 20.04.2019]; Par Latvijas Republikas un Austrijas Republikas konvenciju par nodokḷu dubultās uzlikšanas novēršanu attiecībā uz ienākuma un kapitāla nodokḷiem [Convention between the government of the Republic of Latvia and the Republic of Austria for the avoidance of double taxation with respect to taxes on income and capital], art. 4.2 (25.05.2006). Available: https://likumi.lv/doc.php?id=137397 [last viewed 20.04.2019]; Latvijas Republikas valdības un Krievijas Federācijas valdības līgums par nodokḷu dubultās uzlikšanas un nodokḷu nemaksāšanas novēršanu attiecībā uz ienākuma un kapitāla nodokḷiem [Agreement between the Government of the Russian Federation for the avoidance of double taxation and the prevention of fiscal evasion with respect to taxes on income and capital], art. 4.2 (09.06.2011). Available: https://likumi.lv/doc.php?id=232250 [last viewed 20.04.2019]; Par Latvijas Republikas un Vācijas Federatīvās Republikas līgumu par nodokḷu dubultās uzlikšanas novēršanu attiecībā uz ienākuma un kapitāla nodokḷiem [Agreement between the Republic of Latvia and the Federal Republic of Germany for the Avoidance of Double Taxation with respect to Taxes on Income and on Capital], art. 4.2 (15.05.1997). Available: https://likumi.lv/ doc.php?id=43580 [last viewed 20.04.2019], etc.

40 Par Latvijas Republikas valdības un Lielbritānijas un Ziemeḷīijas Apvienotās Karalistes valdības konvenciju par nodokḷu dubultās uzlikšanas un nodokḷu nemaksāšanas novēršanu attiecībā uz ienākuma un kapitāla pieauguma nodokḷiem [Convention between the government of the Republic of Latvia and the government of the United Kingdom of Great Britain and Northern Ireland for the avoidance of double taxation and the prevention of fiscal evasion with respect to taxes on income and capital gains] (06.11.1996). Available: https://likumi.lv/doc.php?id=41331 [last viewed 20.04.2019]. 
In determining a natural person's 'centre of vital interests', also the place where the family resides, social, political and cultural activities, the possible location of property owned by the person, the place where professional activities are conducted, etc. are used as criteria. A person should not be recognised as a resident for taxation purposes only because a duty to pay taxes arises in a country due to income or capital. ${ }^{41}$

In the Latvian case law, the concept of 'the centre of vital interests' has not been extensively analysed with the purpose of breaking residence ties. Stable judicature has not evolved. Only some court rulings are available. Thus, for example, on the basis of a judgement by the Court of Justice of the European Communities ${ }^{42}$, the Administrative Regional Court (appellate instance court) recognised as the resident of the Kingdom of Denmark a Latvian national, 25 years old, single, who had lived and worked in Denmark for almost eighteen months. Although the natural person had declared his place of residence in Latvia, the Administrative Regional Court recognised the place of employment and permanent residence in the Kingdom of Denmark as 'the centre of interests' and, hence, as the decisive criterion in determining residency, because during this period this person had had neither family nor any other enduring personal or economic interests in Latvia ${ }^{43}$. In improving the case law in determining the residence for taxation purposes, the Supreme Court has recognised that returning to a country for permanent life per se does not change the residency for taxation purposes with respect to the previous years. In the context of the free movement of persons, it is clear that a person may change and often changes his place of sojourn. ${ }^{44}$

3) if the country of residence cannot be determined in accordance with the first two criteria then a natural person is considered as being the resident of that country, which is his habitual place of residence;

4) if the previous criteria do not allow determining a natural person's country of residence then the nationality (citizenship) becomes the decisive criterion; but

5) if a natural person is the citizen of both these states or is not the citizen of any of them then the authorities of the countries party to the convention decide this matter through mutual agreement.

A taxpayer, which is not a natural person, is considered as the resident of Latvia for taxation purposes if it has been established and registered or should have been established and registered in accordance with the laws of the Republic of Latvia.

The place of a taxpayer's registration (incorporation) is not recognised as the decisive criterion in determining the country of residence everywhere. Thus, the criterion of internationally effective place of management (the place where

${ }_{41}$ Ketners, K., Pètersone, M. Eiropas Savienības nodokl̦u politika [European Union tax policy]. Rīga: RTU Press, 2014, pp. 47-49; Ketners, K. Nodokḷi un nodokḷu plānošanas principi [Tax and principles of tax planning]. Rīga: SIA “Tehnoinform Latvia”, 2018, pp. 148-156.

42 The European Court of Justice, Robin Swaddling and Adjudication Officer, C-90/97, 25 February 1999. Available: https://eur-lex.europa.eu/legal-content/EN/TXT/PDF/?uri=CELEX:61997CJ0090 \&from=EN [last viewed 20.04.2019].

43 Administratīvās apgabaltiesas 2014. gada 22. decembra spriedums lietā Nr. A4206664311 [Judgement of 22 December 2014 by the Administrative Regional Court in case No. A4206664311], archive number of the case No. AA43-1524-14/13, para. 13. Available: https://manas.tiesas.lv/ eTiesasMvc/lv/nolemumi [last viewed 20.04.2019].

44 Augstākās tiesas 2012. gada 12. decembra spriedums lietā Nr. SKA-538/2012 (A42954809) [Judgement of 12 December 2012 by the Supreme Court in case No. SKA-538/2012 (A42954809)], Paras. 9, 11-12. Available: http://www.at.gov.lv/lv/judikatura/judikaturas-nolemumu-arhivs/ administrativo-lietu-departaments/hronologiska-seciba?year=2012 [last viewed 20.04.2019]. 
management is located) is used, for example, in Switzerland, Germany, Italy and Russia. ${ }^{45}$ A company's place of effective management can be determined on the basis of the location of the board ('day-to-day management test') or the place where strategic decisions are adopted ('place of strategic management').

Pursuant to different criteria for determining residency in different states, a taxpayer may simultaneously be the resident of not only Latvia. In a case like this, the tax conventions that are in force in Latvia establish the obligation of authorities ${ }^{46}$ to attempt to resolve this matter through mutual agreement. In the absence of such an agreement, the person is not recognised as a resident in any of the states party to the convention for receiving the reliefs envisaged in the convention. ${ }^{47}$

\section{Avoidance of Double Taxation by Using Relief and Credit Methods}

To avoid double taxation, the tax conventions of the EU Member States and the national legislation in many ways are drafted, using the OECD Model Tax Convention $^{48}$ (Model Tax Convention on Income and on Capital). ${ }^{49}$ Also in Latvia, in accordance with OECD model, the relief and credit method can be discussed in connection with avoidance of double taxation with respect to income taxes. As regards the role of the EU law in avoidance of double taxation, the ECJ case C-128/08 (Jacques Damseaux v. État belge) must be taken into account, in the case, a limited EU competence to demand from the Member States avoidance of double taxation is recognised ${ }^{50}$, i.e., the EU law, in its current status, does not define general criteria for allocation of competence among the Member States with respect to avoidance of double taxation. Adverse consequences that follow from the parallel exercise of Member States' tax competence, unless such exercise is discriminatory, are not a prohibited restriction.

\subsection{Avoidance of Double Taxation in Case of Applying PIT}

\subsubsection{Avoidance of Double Taxation with Relief Method}

In Latvia, courts view the relief from application of the income tax as an exception to the general obligation to pay taxes. Therefore, the relief method is

45 See Maisto, G. (ed.). Residence of Companies under Tax treaties and EC Law (Vol. 5). IBFD, 2009; De Broe, L. International tax planning and prevention of abuse: A study under domestic tax law, tax treaties, and EC law in relation to conduit and base companies (Vol. 13). IBFD, 2008.

46 In Latvia - the State Revenue Service.

47 See for instance Convention between the Republic of Latvia and the United States of America for the Avoidance of Double Taxation and the Prevention of Fiscal Evasion with Respect to Taxes on Income, art. 4.5-6; Convention between the government of the Republic of Latvia and the Republic of Austria for the avoidance of double taxation with respect to taxes on income and capital, art. 4.3; Agreement between the Government of the Russian Federation for the avoidance of double taxation and the prevention of fiscal evasion with respect to taxes on income and capital, art. 4.3; Agreement between the Republic of Latvia and the Federal Republic of Germany for the Avoidance of Double Taxation with respect to Taxes on Income and on Capital, art. 4.3.

48 Terra, B. J. M., Wattel, P. J. European tax law. $4^{\text {th }}$ edition. The Hague: Kluwer Law International, 2005, pp. 100-105.

49 Model Tax Convention on Income and on Capital. Condensed version (as it read on 21 November 2017). OECD. Available: https://www.oecd-ilibrary.org/docserver/mtc_cond-2017-en.pdf?expire $\mathrm{s}=1550576533 \& \mathrm{id}=\mathrm{id} \&$ accname $=$ oid019822\&checksum $=44 \mathrm{D} 7021 \mathrm{~F} 19867 \mathrm{~B} 274 \mathrm{~B} 1658 \mathrm{~A} 4964861 \mathrm{~EB}$ [last viewed 20.04.2019], pp. 376-406.

50 Jacques Damseaux vs. État belge, No. C-128/08, 16 July 2009. Available: https://eur-lex.europa.eu/ legal-content/LV/TXT/HTML/?uri=CELEX:62008CJ0128\&from=LV [last viewed 20.04.2019]. 
applicable only with respect to certain types of income concretely defined in the law and it cannot be applied by analogy. The relief method is interpreted as a special method (special norm) with respect to the credit method in the avoidance of double taxation..$^{51}$

Article 24(7) of PIT provides that paid work income of the resident of Latvia is not subject to the personal income tax if three conditions are complied with concurrently: $:^{52}$

1) paid work income obtained for the performance of work duties in another Member State of the European Union or European Economic Area State, or in a state with which Latvia has entered into a convention for the avoidance of double taxation and the prevention of fiscal evasion and it has come into force;

2) paid work income obtained in the relevant foreign state is subject to personal income tax or similar tax thereto;

3) the payer is not personnel, which is hired by a lessor of personnel to a lessee of personnel (resident of Latvia or permanent representation of the nonresident in Latvia). The lessor of the personnel is not a resident of Latvia or permanent representation. ${ }^{53}$

With the employer and the employee being resident of Latvia, the exemption from PIT for the income abroad will be applicable only in the case if the employer has submitted to the Latvian tax administration ${ }^{54}$ confirmation that an income tax is applied to the income from the salary abroad. In addition to that, in the notification to the Latvian tax administration, the employed employee and the periods of his employment must be identified. ${ }^{55}$

Hence, the relief from the obligation to pay the tax in Latvia applies only to the resident's for taxation purposes income from salary abroad, not permitting a situation where the income tax is not paid altogether.

\subsubsection{Avoidance of Double Taxation by Credit Method}

Thus, avoidance of double taxation by the credit method should be examined as the general method for avoiding double taxation. In applying the credit method, the calculated tax is decreased by the amount, which is equal to the tax that has been paid abroad. The decrease may not exceed the sum that would be equal to the tax for income abroad calculated in Latvia. For the right to the tax credit to be recognised, the taxpayer must submit a certified document of the foreign tax administration on the income that has been taxed and the paid amount of tax. The right to decrease the tax calculated in Latvia by the income tax paid abroad is examined individually with respect to each foreign state. ${ }^{56}$

51 Administratīīās apgabaltiesas 2017. gada 30. novembra spriedums lietā Nr. A420282416 [Judgement of 30 November 2017 by the Administrative Regional Court in case No. A420282416], archive number of the case No. AA43-1321-17/14, ECLI:LV:ADAT:2017:1130.A420282416.2.S, para. 5.2. Available: https://manas.tiesas.lv/eTiesasMvc/lv/nolemumi [last viewed 20.04.2019].

52 The personal income tax relief does not apply to a natural person's income from work if a person is employed on a ship used in international transportation. See On Personal Income Tax, art. 8.4, 24.8.

53 On Personal Income Tax, art. 17 $17^{1}$ 24.2,7.

54 To the State Revenue Service.

55 On Personal Income Tax, art. 27.7 1 .

56 See On Personal Income Tax, art. 24.3-4; Uzṇēmumu ienākuma nodokḷa likums [Enterprise Income Tax Law], art. 15.1-3 (28.07.2017). Available: https://likumi.lv/ta/id/292700-uznemumuienakuma-nodokla-likums [last viewed 20.04.2019]. 
Latvia's case law regarding the interpretation of the application of the credit method is not extensive. However, some findings are noteworthy for the application of tax law. Thus, for example, it has been noted in the courts' judicature that if the income tax paid abroad exceeds the personal income tax to be calculated in Latvia, then, for the taxpayer, the income tax paid abroad is the final tax payment. However, if the personal income tax paid abroad is less than the personal income tax calculated in Latvia, the taxpayer must pay into the state budget the difference between the personal income tax to be paid in Latvia and the one paid abroad. Likewise, the courts have interpreted correctly the purpose of tax conventions. The purpose of intergovernmental tax conventions is to avoid double taxation but, at the same time, to prevent tax evasion. ${ }^{57}$

Special regulation has been established for savings income. ${ }^{58}$ PIT, calculated in Latvia, is decreased by the whole tax for savings income that has been paid abroad. The tax administration's obligations include also the duty to reimburse to the actual owner of the savings income the amount by which the tax from savings income calculated abroad exceeds the tax calculated in Latvia. If apart from collecting the tax on savings income also tax from other income has been deducted then, first of all, the credit method with respect to other income is applied. ${ }^{59}$

\subsection{Avoidance of Double Taxation in Case of Applying Enterprise Income Tax}

\subsubsection{Avoidance of Double Taxation by Relief and Credit Method}

On July 28 2017, the new Enterprise Income Tax Law (hereinafter - EITL) was adopted. The period of transition to the new legal relationship ended on 1 July 2018. In accordance with the law, the enterprise income tax (hereinafter - EIT) is not levied to enterprise income (profit) until the moment of distribution of profit or channelling the profit for such expenditure that does ensure further economic development of the payer of EIT; i.e., the application of EIT has been transferred from the moment of gaining the profit to the moment of distribution thereof. ${ }^{60}$

The rate of EIT has established in the amount of $20 \%$. In defining the taxable base for EIT, the value of the object, to which EIT is applied, first of all is divided by the coefficient $0.8 .{ }^{61}$ Only after this the EIT rate of $20 \%$, referred to above, is applied to the obtained value. The payment of EIT is a final payment into the state budget and another income tax is not applied to the disbursed dividends. ${ }^{62}$ The calculations made by economists show that the payment of EIT, introduced in following the

57 Administratīvās apgabaltiesas 2017. gada 14. novembra spriedums lietā Nr. A420277316 [Judgement of 14 November 2017 by the Administrative Regional Court No. A420277316], archive number of the case No. AA43-1117-17/16, ECLI:LV:ADAT:2017:1114, A420277316.2.S, para. 15. Available: https://manas.tiesas.lv/eTiesasMvc/lv/nolemumi [last viewed 20.04.2019].

58 With respect to the special tax, which the Member States of the European Union, territories linked to and dependent on them, states, which are not Member States of the European Union but with which the European Community has concluded international agreements, binding upon Latvia, on taxing savings income, deduct from the savings income, in order for Latvia to ensure implementation of Directive 2003/48/EC on taxation on savings income in the form of interest payments.

59 On Personal Income Tax, art. 24.5-6.

60 Enterprise Income Tax Law, art. 4.

61 Ibid., art. 4.9.

62 See On Personal Income Tax, art. 9.1,2. ${ }^{1}-2 .^{2}$ 
model of the Republic of Estonia, should improve Latvia's economic indicators. ${ }^{63}$ The coming years will show whether this, indeed, is the case.

With EITL coming into force, economic double taxation of commercial activities that existed previously was formally prevented. Until 31 December 2017, EIT with the rate of $15 \%$ was applied to an enterprise's income of the taxation year ${ }^{64}$ and PIT in the rate of $10 \%$ was applied to the dividends disbursed to natural persons ${ }^{65}$.

Pursuant to EITL, a taxpayer has the right to reduce the amount of dividends to be included into the taxable base of the taxation period by the dividends disbursed by another person and disbursements equal to dividends, as well as income received in a monetary or another form from a permanent establishment (hereinafter all income - dividends). If the amount of dividends received in the taxation period exceeds the amount of calculated dividends, the difference can be transferred to the future taxation periods (in chronological order), reducing the amount of dividends to be included in the taxable base. The right to reduce the taxable base applies only to those dividends, from which, in the residence country of the disbursement thereof, the enterprise income tax has been paid or tax has been deducted but the taxable income has not been reduced. ${ }^{66}$

In Latvia, prior to the tax reform of 2018, a slightly different approach was taken to deduction of dividends to be received by companies. In calculating the taxable income, it was reduced by the sum of received dividends (dividend-receiveddeduction). This approach has a similar economic effect but there was no relief from the payment of the tax. Hence, it was not delimited by mechanisms against tax evasion.

If double taxation has not been avoided by the relief method then the taxpayer has the right to reduce the tax on dividends, calculated in the taxation period, by the amount that is equal to the tax paid abroad. To have the right to apply the credit method to income abroad, the taxpayer needs documents approved by the foreign institution that collects taxes, indicating the taxable income and the amount of the tax paid abroad. The reduced amount may not exceed the amount that would be equal to the tax on dividends from income gained abroad that has been calculated in Latvia. ${ }^{67}$

Moreover, EITL law applies tax relief to capital gain ${ }^{68}$ and the income received from publicly traded securities through a financial intermediary. Thus, a taxpayer has the right to reduce the amount of dividends included in the taxable base in the taxation period in the scope, in which the taxpayer, within the taxable period, has gained income from alienation of direct participation shares, the holding period of which at the moment of alienation had been at least 36 months. Whereas to reduce the calculated tax on dividends, upon receiving publicly traded dividends thro is

63 Prohorovs, A. Uzṇēmumu ienākuma nodoklis Latvijā un Igaunijā: tā ietekme uz uzṇēmējdarbību, investīcijām, bezdarba līmeni, nodokḷu ieņēmumiem un valsts ekonomisko izaugsmi [Corporate Income Tax in Latvia and Estonia: Effects on Entrepreneurial Activity, Investment, the Unemployment Rate, Tax Revenues and the Economic Growth of the State] (2017). Available: http://dx.doi.org/10.2139/ssrn.2916437 [last viewed 20.04.2019].

64 Par uzṇēmumu ienākuma nodokli [On Enterprise Income Tax], art. 3.1 (09.02.1995). Available: https://likumi.lv/doc.php?id=34094 [last viewed 20.04.2019].

65 (See the wording of the law until 31.12.2017) On Personal Income Tax, art. 15.3 ${ }^{1}$.

66 Enterprise Income Tax Law, art. 6, 15.4-6.

67 Ibid., art. 15.1-2.

68 Ibid., art. 13. 
required ${ }^{69}$ Likewise, the Latvian tax administration should be able to identify the true beneficiary and the respective securities, from which the income had been paid, from the submitted documents.

In drafting EITL, the legislator has thought also about prevention of tax evasion. As a tax evasion prevention norm, the provision is included that the EIT taxable base may not be reduced by the dividends received from tax havens ${ }^{70}$, a payer of micro-enterprise $\operatorname{tax}^{71}$ or an investment fund / alternative investment fund ${ }^{72}$, i.e., persons with a different regime of tax application.

\subsubsection{The Case of Transfer Pricing}

Another situation of economic double taxation is the case of adjusting transfer pricing. For example, one state increases the taxable income in accordance with price adjustment in transactions with related persons; however, corresponding adjustments with respect to the transaction prices of a related person do not follow in the other state. As the result, the profit from a transaction between related persons is taxed twice.

Pursuant to EITL section 4, for taxpayers the taxable base of EIT is formed by aggregating the objects calculated in Latvia and abroad in the taxation period. These objects include income that the taxpayer would have received or expenditure that the taxpayer would have incurred if the commercial or financial relationships had been created or established in accordance with the rules in force between two independent persons, i.e.; the value of concluded transactions must correspond to the market price (value).

This case of economic double taxation is avoided by using the regulation of conventions that allows distributing the right to tax between two countries. The sources of international legal regulation on transfer prices are the OECD Model Tax Convention and the UN Model Tax Convention. The tax conventions concluded by Latvia also include article 9 on defining the principle of transactions between unrelated enterprises and the basic principles of profit adjustment and article 25, which contains a reference to the Mutual Agreement Procedure (MAP) as a mechanism for dispute resolution in the case of establishing transfer prices. ${ }^{73}$

69 A document, issued to the financial intermediary by the tax collection institution in a Member State of the EU or a state, with which Latvia has concluded a convention on avoiding double taxation and tax evasion and the convention has entered into effect or an agreement on exchanging tax-related information, is considered as being such a statement. If the financial intermediary is a resident of the states referred to above then it is enough to have a statement by the financial intermediary itself on payment of taxes abroad. See Enterprise Income Tax Law, art. 15.7-8.

70 Dividends, which are disbursed by persons, which have been created or established in states or territories of low taxes or no taxes, are considered to be dividends of 'tax havens'. Such states and territories are enumerated in Latvia's so-called 'blacklist'. See Par zemu nodokḷu vai beznodokḷu valstīm un teritorijām [On Low Tax or No Tax Sates and Territories] (07.11.2017). Available: https:// likumi.lv/ta/id/294935 [last viewed 20.04.2019].

71 The micro-enterprise tax is paid from the enterprise's turnover. See Mikrouznēmumu nodokḷa likums [Micro-enterprise Tax Law] (09.08.2010). Available: https://likumi.lv/doc.php?id=215302 [last viewed 20.04.2019].

72 Enterprise Income Tax Law, art. 6.

73 See for instance Convention between the Republic of Latvia and the Republic of Austria for the avoidance of double taxation with respect to taxes on income and on capital; Agreement between the Republic of Latvia and the Federal Republic of Germany for the Avoidance of Double Taxation with respect to Taxes on Income and on Capital; Par Latvijas Republikas un Japānas konvenciju par nodokḷu dubultās uzlikšanas attiecībā uz ienākuma nodokḷiem, ḷaunprātīgas izvairīšanās no nodokḷu maksāšanas un nodokḷ nemaksāšanas novēršanu [Convention between 
The Arbitration Convention operates in the EU law. ${ }^{74}$ Pursuant to its article 14, the double taxation of profits is regarded as eliminated, if the profits are included in the computation of taxable profits in one state only, or if the tax chargeable on those profits in one state is reduced by an amount equal to the tax chargeable on these in the other. The risk of double taxation in the case of transfer prices, basically, can occur in situations, where the taxpayer, upon establishing non-conformity of a transfer price with the market price, adjusts its taxable income. To avoid occurrence of double taxation (taxation in each country of the taxpayers), the conventions concluded by the states have included the second part of article 9, following the OECD Model Tax Convention, which provides "the other State must introduce corresponding changes with respect to the amount of tax charged on this profit in the other State". One of the most authoritative international sources in the area of transfer prices, which is used by states, attempting to introduce in their national regulatory enactments legal regulation on transfer prices (including the requirements regarding the documentation of transfer prices), is the OECD document "OECD Transfer Pricing Guidelines for Multinational Enterprises and Tax Administrations"75 (OECD Guidelines on Transfer Pricing). In July 2017, thanks to OECD/G20 Project on Base Erosion and Profit Shifting Action Plans, the Guidelines were substantially revised ${ }^{76}$. The Guidelines comprise both general principles and practical references to methods to be applied to a transaction and on preparing documentation, and currently this is the only regulation of practical significance that is used in determining transfer prices. The Guidelines have been used also in working out the Latvian practical application of transfer prices. ${ }^{77}$ Thus, the impact of this type of economic double taxation is decreased.

the Republic of Latvia and Japan for the elimination of double taxation with respect to taxes on income and the prevention of tax evasion and avoidance] (30.03.2017). Available: https://likumi.lv/ doc.php?id=289934 [last viewed 20.04.2019]. etc.

74 Konvencija par nodokḷu dubultās uzlikšanas novēršanu sakarā ar asociēto uzñēmumu peḷnas korekciju Nr. 90/436/EEC [Convention on the elimination of double taxation in connection with the adjustment of profits of associated enterprises No. 90/436/EEC]. Available: https://eur-lex. europa.eu/legal-content/en/ALL/?uri=CELEX\%3A41990A0436 [last viewed 20.04.2019].

75 OECD Transfer Pricing Guidelines for Multinational Enterprises and Tax Administrations 2017. OECD Publishing, Paris. Available: http://dx.doi.org/10.1787/tpg-2017-en [last viewed 20.04.2019].

76 Ibid.

77 "Regulation on Applying the Norms of the Enterprise Income Tax Law" allow using OECD Guidelines as a supplementary source of law and provide that, insofar it is not contrary to the rights and obligations of the taxpayer and the tax administration defined in regulatory enactments, the document of the Organisation of Economic Co-operation and Development "Transfer Pricing Guidelines for Multinational Enterprises and Tax Administrations" may be used as a supplementary source to apply the techniques for determining the market prices (values) of transactions (the market price (value) of goods (product), service, intangible property or another object of transaction) and techniques of economic analysis referred to in paragraph $9,13,14,15$, 16 and 17, to perform the functional analysis and the analysis of comparability in accordance with paragraphs $8,9,10,11$ and 12 of this Regulation, to facilitate cooperation between a taxpayer and the tax administration, and to avoid double taxation; to substantiate the economic essence of specific controlled transactions (services, agreements on cost investments, transactions with intangible property, restructurisation) and to document these. See Uzṇēmumu ienākuma nodokḷa likuma normu piemērošanas noteikumi [Regulation on Applying the Norms of the Enterprise Income Tax Law] (14.11.2017). Available: https://likumi.lv/ta/id/295416-uznemumu-ienakumanodokla-likuma-normu-piemerosanas-noteikumi [last viewed 20.04.2019]. 


\section{Summary}

1. Latvia addresses the issue of avoiding double taxation in the area of income tax in compliance with the international commitments and the OECD recommendations in the area of avoiding double taxation; i.e.: by the methods of residence tiebreaker, relief and credit. The procedure for establishing transfer prices is a special case.

2. The Latvian courts interpret the relief method as a special method (special norm) with respect to the credit method for avoiding double taxation. Therefore, the relief method is applicable only with respect to types of income particularly defined in the law and is not applicable by analogy.

3. The purpose of methods for avoiding double taxation is incompatible with tax evasion. Therefore, the so-called anti-avoidance / anti-evasion norms have been integrated into the Latvian tax laws to prevent a situation where income taxes are not paid altogether.

\section{Sources}

\section{Bibliography}

1. De Broe, L. International tax planning and prevention of abuse: A study under domestic tax law, tax treaties, and EC law in relation to conduit and base companies (Vol. 13). IBFD, 2008.

2. Eiropas nodoklii Latvijā [European Taxes in Latvia]. Rīga: Latvijas Ekonomists, Ernst \& Young, 2004.

3. Frotscher, G. Internationales Steuerrecht. 4., völlig überarbeitete Auflage. München: Verlag C. H. Beck, 2015.

4. Haase, F. Internationales und Europisches Steuerrecht. 4., neu bearbeitete Auflage. Heidelberg, München, Landsberg, Frechen, Hamburg: C. F. Müller, 2014.

5. Ketners, K. Nodokḷu plānošanas principi [Principles of tax planning]. Rìga: SIA "Tehnoinform Latvia", 2018.

6. Ketners, K., Pètersone, M. Eiropas Savienības nodokḷu politika [European Union tax policy]. Rìga: RTU Press, 2014.

7. Lazdiñ̌s J., Ketners, K. The Effect of Court Rulings on the Dynamics of the Latvian Tax Law. Journal of the University of Latvia. Law, No. 5, 2013, pp. 22-43.

8. Maisto, G. (ed.). Residence of Companies under Tax treaties and EC Law (Vol. 5). IBFD, 2009.

9. Model Tax Convention on Income and on Capital. Condensed version (as it read on 21 November 2017). OECD. Available: https://www.oecd-ilibrary.org/docserver/mtc_cond-2017-en.pdf?expires= $1550576533 \& \mathrm{id}=\mathrm{id} \& \mathrm{accname}=$ oid019822\& $\mathrm{checksum}=44 \mathrm{D} 7021 \mathrm{~F} 19867 \mathrm{~B} 274 \mathrm{~B} 1658 \mathrm{~A} 4964861 \mathrm{~EB}$ [last viewed 20.04.2019].

10. OECD Transfer Pricing Guidelines for Multinational Enterprises and Tax Administrations 2017. OECD Publishing, Paris. Available: http://dx.doi.org/10.1787/tpg-2017-en [last viewed 20.04.2019].

11. Prohorovs, A. Uzṇēmumu ienākuma nodoklis Latvijā un Igaunijā: tā ietekme uz uzṇēmējdarbību, investīijām, bezdarba līmeni, nodokḷu ienēemumiem un valsts ekonomisko izaugsmi [Corporate Income Tax in Latvia and Estonia: Effects on Entrepreneurial Activity, Investment, the Unemployment Rate, Tax Revenues and the Economic Growth of the State] (2017). Available: http:// dx.doi.org/10.2139/ssrn.2916437 [last viewed 20.04.2019].

12. Terra, B. J. M., Wattel, P. J. European tax law. $4^{\text {th }}$ edition. The Hague: Kluwer Law International, 2005.

13. Vogel, K. et al. Klaus Vogel on Double Taxation Conventions. A Commentary to the OECD-, UNand US Model Conventions for the Avoidance of Double Taxation on Income and Capital. With Particular Reference to German Treaty Practice. $3^{\text {rd }}$ edition. London: Kluwer Law International Ltd., 1995.

\section{Normative Acts (Law)}

1. Latvijas Republikas Satversme [The Constitution of the Republic of Latvia] (15.02.1922), art. 105. Available: https://likumi.lv/doc.php?mode=DOC\&id=57980 [last viewed 20.04.2019]. 
2. Līgums par Eiropas Savienibbas darbību [The Treaty on the Functioning of the European Union], art. 113. Available: https://eur-lex.europa.eu/legal-content/LV/TXT/?uri=CELEX\%3A12012E\% 2FTXT [last viewed 20.04.2019].

3. Konvencija par nodokḷu dubultās uzlikšanas novēršanu sakarā ar asociēto uzṇēmumu peḷñas korekciju [Convention on the elimination of double taxation in connection with the adjustment of profits of associated enterprises], No. 90/436/EEC. Available: https://eur-lex.europa.eu/legalcontent/en/ALL/?uri=CELEX\%3A41990A0436 [last viewed 20.04.2019].

4. Par Latvijas Republikas valdības un Lielbritānijas un Ziemel̦iirijas Apvienotās Karalistes valdības konvenciju par nodokḷu dubultās uzlikšanas un nodokḷu nemaksāšanas novēršanu attiecībā uz ienākuma un kapitāla pieauguma nodokḷiem [Convention between the government of the Republic of Latvia and the government of the United Kingdom of Great Britain and Northern Ireland for the avoidance of double taxation and the prevention of fiscal evasion with respect to taxes on income and capital gains] (06.11.1996). Available: https://likumi.lv/doc.php?id=41331 [last viewed 20.04.2019].

5. Par Latvijas Republikas un Vācijas Federatīvās Republikas līgumu par nodokḷu dubultās uzlikšanas novēršanu attiecībā uz ienākuma un kapitāla nodokḷiem [Agreement between the Republic of Latvia and the Federal Republic of Germany for the Avoidance of Double Taxation with respect to Taxes on Income and on Capital] (15.05.1997), art. 4.2. Available: https://likumi.lv/doc.php?id=43580 [last viewed 20.04.2019].

6. Par Latvijas Republikas un Amerikas Savienoto Valstu konvenciju par nodokḷu dubultās uzlikšanas un nodokḷu nemaksāšanas novēršanu attiecībā uz ienākuma nodokḷiem [Convention between the Republic of Latvia and the United States of America for the Avoidance of Double Taxation and the Prevention of Fiscal Evasion with Respect to Taxes on Income] (14.05.1998). Available: https:// likumi.lv/doc.php?id=48313 [last viewed 20.04.2019].

7. Par Latvijas Republikas un Austrijas Republikas konvenciju par nodokḷu dubultās uzlikšanas novēršanu attiecībā uz ienākuma un kapitāla nodokḷiem [Convention between the government of the Republic of Latvia and the Republic of Austria for the avoidance of double taxation with respect to taxes on income and capital] (25.05.2006). Available: https://likumi.lv/doc.php?id=137397 [last viewed 20.04.2019].

8. Mikrouzṇēmumu nodokḷa likums [Micro-enterprise Tax Law] (09.08.2010). Available: https:// likumi.lv/doc.php?id=215302 [last viewed 20.04.2019].

9. Latvijas Republikas valdības un Krievijas Federācijas valdības līgums par nodokḷu dubultās uzlikšanas un nodokḷu nemaksāšanas novēršanu attiecībā uz ienākuma un kapitāla nodokḷiem [Agreement between the Government of the Russian Federation for the avoidance of double taxation and the prevention of fiscal evasion with respect to taxes on income and capital] (09.06.2011). Available: https://likumi.lv/doc.php?id=232250 [last viewed 20.04.2019].

10. Par Latvijas Republikas un Japānas konvenciju par nodokḷu dubultās uzlikšanas attiecībā uz ienākuma nodokḷiem, l̦aunprātīgas izvairīšanās no nodokḷu maksāšanas un nodokḷu nemaksāšanas novēršanu [Convention between the Republic of Latvia and Japan for the elimination of double taxation with respect to taxes on income and the prevention of tax evasion and avoidance] (30.03.2017). Available: https://likumi.lv/doc.php?id=289934 [last viewed 20.04.2019].

11. Līgums par Latvijas Republikas pievienošanās konvencijai par Ekonomiskās sadarbības un attīstības organizāciju nosacijumiem [Agreement on the terms of accession of the Republic of Latvia to the convention on the Organisation for economic co-operation and development] (29.04.2016). Available: https://likumi.lv/ta/lv/starptautiskie-ligumi/id/1249 [last viewed 20.04.2019].

12. Über die Besteuerung des Einkommens natürlicher Personen (07.07.1988). Available: https://www. ris.bka.gv.at/GeltendeFassung.wxe?Abfrage=Bundesnormen \&Gesetzesnummer $=10004570$ [last viewed 20.04.2019].

13. Par nodokḷiem un nodevām [On Taxes and Duties] (02.02.1995), art. 8. Available: https://likumi.lv/ doc.php?id=33946 [last viewed 20.04.2019.].

14. Par uzṇēmumu ienākuma nodokli [On Enterprise Income Tax] (09.02.1995), art. 3.1. Available: https://likumi.lv/doc.php?id=34094 [last viewed 20.04.2019].

15. Par iedzìvotāju ienākuma nodokli [On Personal Income Tax] (11.05.1993). Available: https://likumi. lv/doc.php?id=56880 [last viewed 20.04.2019].

16. Solidaritātes nodokḷa likums [Solidarity Tax Law] (30.11.2015). Available: https://likumi.lv/ta/ id/278636-solidaritates-nodokla-likums [last viewed 20.04.2019].

17. Uzņēmumu ienākuma nodokḷa likums [Enterprise Income Tax Law] (28.07.2017). Available: https://likumi.lv/ta/id/292700-uznemumu-ienakuma-nodokla-likums [last viewed 20.04.2019]. 


\section{Normative Acts (Regulations)}

1. Par valsts sociālās apdrošināšanas obligāto un brīvprātīgo iemaksu objekta minimālo un maksimālo apmēru [Regulations Regarding the Minimum and Maximum Amount of the Object of Mandatory and Voluntary Contributions of State Social Insurance] (17.12.2013). Available: https://likumi.lv/ doc.php?id=263238 [last viewed 20.04.2019].

2. Noteikumi par zemu nodokḷu vai beznodokḷu valstīm un teritorijām [Regulation on Low Tax or No Tax States and Territories] (07.11.2017). Available: https://likumi.lv/ta/id/294935 [last viewed 20.04.2019].

3. Uzñēmumu ienākuma nodokḷa likuma normu piemērošanas noteikumi [Regulation on Applying the Norms of the Enterprise Income Tax Law] (14.11.2017). Available: https://likumi.lv/ta/ id/295416-uznemumu-ienakuma-nodokla-likuma-normu-piemerosanas-noteikumi [last viewed 20.04.2019].

\section{Case Law}

\section{The European Court of Justice}

1. Robin Swaddling and Adjudication Officer, C-90/97, 25 February 1999. Available: https://eur-lex. europa.eu/legal-content/EN/TXT/PDF/?uri=CELEX:61997CJ0090\&from=EN [last viewed 20.04.2019].

2. Marks \& Spencer plc. vs. David Halsey (Her Majesty's Inspector of Taxes), No. C-446/03, 13 December 2005. Available: http://curia.europa.eu/juris/document/document.jsf?text=\&docid=57067\&pageIn $\mathrm{dex}=0$ \&doclang $=\mathrm{LV} \&$ mode $=$ lst \&dir $=\&$ occ $=$ first \&part $=1 \& \mathrm{cid}=12001880$ [last viewed 20.04.2019].

3. Margaret Block vs. Finanzamt Kaufbeuren, No. C-67/08, 12 February 2009. Available: http://curia. europa.eu/juris/document/document.jsf;jsessionid=631055E95D4364261C819C062E8BCF81?text $=\&$ docid $=76237 \&$ pageIndex $=0 \&$ doclang $=$ LV \&mode $=1$ st $\&$ dir $=\& o c c=$ first $\&$ part $=1 \& c i d=12000413$ [last viewed 20.04.2019].

4. Jacques Damseaux vs. État belge, No. C-128/08, 16 July 2009. Available: https://eur-lex.europa.eu/ legal-content/LV/TXT/HTML/?uri=CELEX:62008CJ0128\&from=LV [last viewed 20.04.2019].

\section{Constitutional Court of the Republic of Latvia}

1. Latvijas Republikas Satversmes tiesas 2011. gada 20. maija spriedums lietā Nr. 2010-70-01 [Judgement of 20 Mary 2011 by the Constitutional Court of the Republic of Latvia in case No. 2010-70-01], para. 9. Available: http://www.satv.tiesa.gov.lv/wp-content/uploads/2016/02/ 2010-70-01_Spriedums.pdf [last viewed 20.04.2019].

2. Latvijas Republikas Satversmes tiesas 2015. gada 25. marta spriedums lietā Nr. 2014-11-0103 [Judgement of 25 March 2015 by the Constitutional Court of the Republic of Latvia in case No. 2014-11-0103], para. 20. Available: http://www.satv.tiesa.gov.lv/wp-content/uploads/ 2016/02/2014-11-0103_Spriedums.pdf [last viewed 20.04.2019].

3. Latvijas Republikas Satversmes tiesas 2010. gada 6. decembra spriedums lietā Nr. 2010-25-01 [Judgement of 6 December 2010 by the Constitutional Court of the Republic of Latvia in case No. 2010-25-01], para. 10. Available: http://www.satv.tiesa.gov.lv/web/viewer.html?file=http://www. satv.tiesa.gov.lv/wp-content/uploads/2016/02/2010-25-01_Spriedums.pdf\#search= [last viewed 20.04.2019].

4. Latvijas Republikas Satversmes tiesas 2010. gada 19. jūnija spriedums lietā Nr. 2010-02-01 [Judgement of 19 June 2010 by the Constitutional Court of the Republic of Latvia in case No. 201002-01], para. 6. Available: http://www.satv.tiesa.gov.lv/wp-content/uploads/2016/02/2010-02-01_ Spriedums.pdf [last viewed 20.04.2019].

5. Latvijas Republikas Satversmes tiesas 2017. gada 19. oktobra spriedums lietā Nr. 2016-14-01 [Judgement of 19 October 2017 by the Constitutional Court of the Republic of Latvia in case No. 2016-14-01], para. 2. Available: http://www.satv.tiesa.gov.lv/web/viewer.html?file= http://www.satv.tiesa.gov.lv/wp-content/uploads/2016/07/2016-14-01_Spriedums-2.pdf\#search= [last viewed 20.04.2019].

6. Latvijas Republikas Satversmes tiesas 2017. gada 16. novembra spriedums lietā Nr. 2016-16-01 [Judgement of 16 November 2017 by the Constitutional Court of the Republic of Latvia in case No. 2016-16-01], para. 3. Available: http://www.satv.tiesa.gov.lv/web/viewer.html?file=http://www. satv.tiesa.gov.lv/wp-content/uploads/2017/11/2016-16-01_Spriedums.pdf\#search [last viewed 20.04.2019]. 


\section{Judgments of Administrative Courts}

1. Augstākās tiesas 2012. gada 12. decembra spriedums lietā Nr. SKA-538/2012 (A42954809) [Judgement of 12 December 2012 by the Supreme Court in case No. SKA-538/2012 (A42954809)], paras. 9-12. Available: http://www.at.gov.lv/lv/judikatura/judikaturas-nolemumu-arhivs/administrativo-lietu-departaments/hronologiska-seciba?year=2012 [last viewed 20.04.2019].

2. Augstākās tiesas 2016. gada 12. decembra spriedums lietā Nr. SKA-739/2016 (A420479613) [Judgement of 12 December 2016 by the Supreme Court case No. SKA-739/2016 (A420479613)]. Available: https://manas.tiesas.lv/eTiesasMvc/lv/nolemumi; file://C:/Users/LU\%20JF/Downloads/ Anonimizets_nolemums_291360.pdf [last viewed 20.04.2019].

3. Administratīvās apgabaltiesas 2014. gada 22. decembra spriedums lietā Nr. A4206664311 [Judgement of 22 December 2014 by the Administrative Regional court in case No. A4206664311], archive number of the case No. AA43-1524-14/13. Available: https://manas.tiesas.lv/eTiesasMvc/lv/ nolemumi [last viewed 20.04.2019].

4. Administratīvās apgabaltiesas 2017. gada 14. novembra spriedums lietā Nr. A420277316 [Judgement of 14 November 2017 by the Administrative Regional Court in case No. A420277316], archive number of the case No. AA43-1117-17/16, ECLI:LV:ADAT:2017:1114, A420277316.2.S, para. 15. Available: https://manas.tiesas.lv/eTiesasMvc/lv/nolemumi [last viewed 20.04.2019].

5. Administratīiās apgabaltiesas 2017. gada 30. novembra spriedums lietā Nr. A420282416 [Judgement of 30 November 2017 by the Administrative Regional Court in case No. A420282416], archive number of the case No. AA43-1321-17/14, ECLI:LV:ADAT:2017:1130.A420282416.2.S, para. 5.2. Available: https://manas.tiesas.lv/eTiesasMvc/lv/nolemumi [last viewed 20.04.2019]. 


\title{
Political Parties and Their Funding in Germany
}

\author{
Prof. Dr. Thomas Schmitz* \\ Fakultas Hukum, Universitas Gadjah Mada, Yogyakarta \\ DAAD Lecturer in Law \\ E-mail: tschmit1@gwdg.de
}

In Germany, as in most modern democracies, the funding of political parties is a sensitive issue and even after a changeful history of party funding with many scandals the present model is not perfect. There is a combination of private funding and partial public funding (which must, however, not affect the freedom of the political parties from state influence [Staatsfreiheit der Parteien]), flanked by strict rules of financial accountability. Donations are the most controversial element. There is neither a ban on donations from companies nor an absolute limit for donations. Only donations of more than $50000 €$ must be reported immediately and will be made public in a timely manner so that it is ensured that the citizens are informed about them before the next elections. Concerning public funding, there is an indirect funding through income tax reductions on membership fees and (limited) on donations, plus a direct public funding (per vote and per contribution), which must not be higher than the revenue from private funding. Since 2017, parties seeking to undermine or abolish the free and democratic constitutional order shall be excluded from the public funding.

In order to ensure transparency, every party must submit for each calender year a correct and exhaustive audited public statement of accounts. In case of illegal donations or incorrectness of the statement there are sanctions, which are, however, rather soft. The Council of Europe's Group of States against Corruption (GRECO) has criticised the intransparency arising from the fact that party donations up to $50000 €$ do not need to be reported immediately but only in the annual statement of accounts, which may be published several months after the elections influenced by them. So there is still room for improvement.

Keywords: political parties, party funding in Germany, freedom of political parties from state influence [Staatsfreiheit der Parteien], principle of equal opportunities of the political parties, transparency, private and public party funding; party donations, informal election campaign support as party funding, absolute and relative upper limit of public party funding, financial accountability of political parties, public statement of accounts of a political party.

\section{Contents}

Introduction . . . . . . . . . . . . . . . . . . . . . . . . . . . 87

1. Constitutional and Legal Basis of Political Parties in Germany . . . . . . . . . . . . . 87

2. Changeful History of Party Funding in Germany . . . . . . . . . . . . . 88

DAAD lecturer in law at Universitas Gadjah Mada, Yogyakarta, Indonesia; DAAD lecturer at the University of Latvia 2006-2010; Ausserplanmäßiger Professor (adjunct professor) at the GeorgAugust-Universität Göttingen, Germany. The following text was a contribution to the Fifth Indonesian National Conference of Constitutional Law, Universitas Andalas, Padang, 09-11/11/2018. 


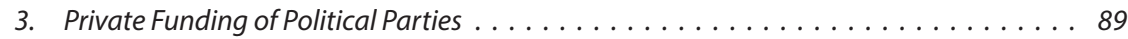

3.1. Membership Fees . . . . . . . . . . . . . . . . . . . . 89

3.2. Regular Contributions by Elected Office-Holders . . . . . . . . . . . . . . . . 89

3.3. Donations . . . . . . . . . . . . . . . . . . . . . . . . . . 90

3.4. Revenues from Other Activities . . . . . . . . . . . . . . . . . . . . . 91

4. Partial Public Funding of Political Parties . . . . . . . . . . . . . . . . . . . . . . . 91

4.1. Indirect Public Funding through Income Tax Reductions on

Membership Fees and Donations . . . . . . . . . . . . . . . . . . . 91

4.2. Direct Public Funding . . . . . . . . . . . . . . . . . . . . . . . 91

4.3. Since 2017: Exclusion of Parties Seeking to Undermine

or Abolish the Free and Democratic Constitutional Order . . . . . . . . . . . . . . 92

5. Financial Accountability of Political Parties . . . . . . . . . . . . . . . 93

5.1. Striving for Transparency: Constitutional Obligation $t$

o Publicly Account for Sources and Use of Funds and for Assets . . . . . . . . . 93

5.2. Current Concretisation of Accountability in the Political Parties Act . . . . . . . . 93

Summary. . . . . . . . . . . . . . . . . . . . . . . . . . . . . 94

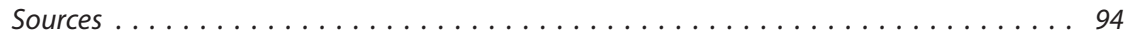

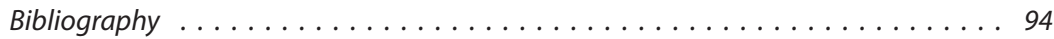

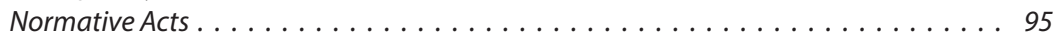

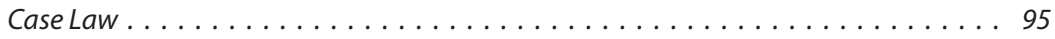

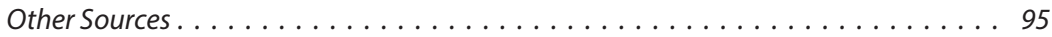

\section{Introduction}

The funding of political parties is a sensitive issue in most modern democracies. Germany is a highly developed constitutional state with a stable democracy where the rule of law is guaranteed in theory and effectively implemented in practice. However, those who look at Germany to find the perfect model for a fair party funding system that ensures equal opportunities of all political parties may be disappointed: Also the German system has its flaws and deficiencies, and scandals have been numerous in recent history.

\section{Constitutional and Legal Basis of Political Parties in Germany}

1.1. In order to prevent any abuse of the partial direct public funding of political parties (see infra, 4.2), the German Act on Political Parties (Political Parties Act $=\mathrm{PPA})^{1}$ includes a restrictive legal definition of 'political parties'. According to sect. 2 PPA, political parties are associations of citizens with a continuous will to influence the political decision-making at national or state level and to participate in the representation of the people in the German Bundestag or a Land parliament provided that, by their actual overall situation and standing, especially as regards the size and strength of their organization, their membership numbers, and their visibility in public, it is ensured that they pursue this aim seriously. Specialised action groups or local voters' associations are not considered as parties. A party loses its status if it does not participate in parliamentary elections for six years.

1 Gesetz über die politischen Parteien (Parteiengesetz) [Act on Political Parties (Political Parties Act)] in the version published on 31/01/1994. Available: www.gesetze-im-internet.de/partg [last viewed 17.06.2019]; see also the illustrative but not in every detail correct and precise English translation at the website of the Bundeswahlleiter [Federal Returning Officer]. Available: www.bundeswahlleiter.de/ en/bundestagswahlen/2017/rechtsgrundlagen.html [last viewed 17.06.2019]. 
1.2. The matters concerning the political parties are mainly regulated in the Political Parties Act. Furthermore, there are some provisions on special aspects in the Federal Elections Act [Bundeswahlgesetz], the Federal Constitutional Court Act [Bundesverfassungsgerichtsgesetz], the Civil Code [Bürgerliches Gesetzbuch] and the Income Tax Act [Einkommensteuergesetz]. However, the most important provision is the political parties clause of art. 21 of the German Basic Law [= BL], the German constitution of $1949,{ }^{2}$ which provides a constitutional basis for the involvement of political parties in the political process. According to art. 21(1) BL, "political parties shall participate in the formation of the political will of the people. They may be freely established. Their internal organisation must conform to democratic principles. They must publicly account for the sources and use of their funds and for their assets."

1.3. Under art. 21(1) BL, the political parties have an important constitutional mission: to participate in the formation of the political will of the people. The German constitution considers them as something valuable and necessary in a free and democratic system. It does not share the scepticism towards the political parties which is characteristic for many modern societies (the German society included). As described in detail in an enthusiastic manner in sect. 1 PPA, the political parties play an essential role as intermediary between state and society.

1.4. Though the parties have the legal nature of associations under private law, they enjoy the status of constitutional institutions (but not state institutions). art. 21(1) also guarantees the freedom of political parties: the free establishment, the free determination of the political program, the freedom of political action and even the free organisation of the party (however, in line with democratic principles and standards set in the Political Parties Act). Political parties can only be prohibited in case of active fight against the free and democratic constitutional order and only in a special procedure before the Federal Constitutional Court [Bundesverfassungsgericht] (art. 21(2,4) BL). Finally, there is a principle of equal opportunities of the parties, which derives from the art. 21(1) read together with art. 38(1) phrase $1 \mathrm{BL}$ (here: the principle of equal elections). It requires in particular equal access of all political parties to public facilities, amenities and services. ${ }^{3}$

\section{Changeful History of Party Funding in Germany}

Germany has a changeful history of party funding. Even under the Basic Law there have been several legal reforms and adjustments, due to numerous scandals but also to the changing jurisprudence of the Federal Constitutional Court. Three landmark decisions should be highlighted:

In a decision of $1958^{4}$ the Federal Constitutional Court considered a general public funding of political parties acceptable but provisions allowing the deduction of the expenses for party donations from the taxable base for the calculation of the income tax up to a limit of 5 percent of the annual income unconstitutional because it favoured the influence of citizens with higher income. In a decision of $1966^{5}$,

2 Grundgesetz für die Bundesrepublik Deutschland [Basic Law for the Federal Republic of Germany] of 1949. Available: www.gesetze-im-internet.de/gg/index.html; English translation at: www.gesetzeim-internet.de/englisch_gg/index.html [last viewed 17.06.2019].

3 See for the details sect. 5 PPA.

4 Federal Constitutional Court, judgement of 24/06/1958, 2 BvF 1/57, BVerfGE 8, 51(63 ff) [= Decisions of the Federal Constitutional Court, vol. 8, p. $51 \mathrm{ff}$, cited passage at p. $63 \mathrm{ff}$ ].

5 Federal Constitutional Court, judgement of 19/07/1966, 2 BvF 1/65, BVerfGE 20, 56. 
however, the Court limited any direct public funding to lump sums for election campaign expenses. In a decision of $1992^{6}$ it explicitly changed its jurisprudence again and accepted a partial general direct public funding as constitutional but formulated an absolute upper limit and a relative upper limit set by the revenue generated by the party itself.

Again and again the Federal Constitutional Court emphasized the principle of the freedom of the political parties from state influence [Staatsfreiheit der Parteien]. ${ }^{7}$ Even under the conditions of partial public funding the parties must be independent from the state and preserve their character as free associations rooted in the socialpolitical sphere. The public funding must not relieve them from the need to seek financial support by their members and followers. ${ }^{8}$

Nowadays, Germany has a mixed system of private and public funding of political parties, in which both elements are closely connected. Usually, when necessary, details are re-adjusted.

\section{Private Funding of Political Parties}

The various sources of private party funding are listed in sect. 24(4) No. 1-7 PPA and are submitted to some regulations in sect. 25 and 27 PPA.

\subsection{Membership Fees}

Membership fees are still an important source of income of the political parties, for some parties even the most important private source of income. ${ }^{9}$ The big parties (Christian and social democrats) have a large number of members. Some small parties (e.g. greens and leftists) charge higher membership fees. While the number of party members has declined for most parties, the membership fees have risen in the recent years. ${ }^{10}$

\subsection{Regular Contributions by Elected Office-Holders}

A part of the income of political parties is generated by regular money payments made by holders of an elected public office (in particular members of parliament and mayors) in addition to their membership fees. This source of income is expressly recognized in sect. 24(4) No. 2 and sect. 27(1) phrase 2 PPA. While some scholars have criticised this practice as unconstitutional in the past ("public funding through the back door"), according to the prevailing opinion there are no constitutional objections. There is only a discussion if the contributions by elected office-holders need to be limited to a maximum of 50 percent of the renumeration

${ }^{6}$ Federal Constitutional Court, judgement of 09/04/1992, 2 BvE 2/89, BVerfGE 85, 264 (see headnote 2).

7 See, for example, Federal Constitutional Court, judgement of 19/07/1966, 2 BvF 1/65, BVerfGE 20, 56(102); judgement of 14/07/1986, 2 BvE 2/84, 2 BvR 442/84, BVerfGE 70, 40 (95 ff); judgement of 09/04/1992, 2 BvE 2/89, BVerfGE 85, 264 (headnote 2, 287 ff); judgement of 06/12/2001, 2 BvE 3/94, BVerfGE 104, 287(302).

8 Federal Constitutional Court, judgement of 09/04/1992, 2 BvE 2/89, BVerfGE 85, 264 (headnotes 1 and 2, p. 287).

9 See the data for the year 2014 in the diagrams of Niedermayer, O. Einnahmen und Ausgaben der Parteien, contribution for the Bundeszentrale für politische Bildung, 12/07/2017. Available: www. bpb.de/politik/grundfragen/parteien-in-deutschland/zahlen-und-fakten/42237/einnahmen-undausgaben [last viewed 17.06.2019].

10 See the report of Zschäpitz, H. Besonders eine Partei langt bei den Mitgliedsbeiträgen zu. In: Welt, 21/09/2017. Available: www.welt.de/wirtschaft/article168881711/Besonders-eine-Partei-langt-beiden-Mitgliedsbeitraegen-zu.html [last viewed 17.06.2019]. 
received from the state. ${ }^{11}$ However, with regard to the fact that the dimension of the parliamentary allowances has been criticised heavily for many years in the German public and, thus, this is a politically sensitive topic with the potential to endanger the acceptance of parliamentary democracy in Germany, it would be very difficult to explain a diversion of 50 percent of the tax payers money provided by the state to finance the professional work of the office-holders to political groups such as the political parties. The limits of this diversion must be defined much stricter.

\subsection{Donations}

Donations are the most controversial element of party funding in Germany. There have been numerous party donation scandals in the past ${ }^{12}$ and in the present ${ }^{13}$. Sect. 25 PPA limits the right of political parties to accept donations and sets procedural rules aiming to provide transparency. There is a ban on donations from certain donors such as public corporations, state-owned enterprises and partly (by more than 25 percent) state-owned enterprises, parliamentary factions, factions of municipal councils, non-profit, charity and church organisations and professional organisations - but no ban on donations from companies. Donations in cash and donations of foreigners who are not European Union citizens are limited to an amount of $1000 €$, anonymous donations even to an amount of $500 €$. However, despite vivid debates in the past, there is no absolute limit for donations, not even a limit for donations from companies. Donations of more than $300000 €$ are not rare and usually foster conservative or liberal parties.

Donations of more than $10,000 €$ in total in a year must be listed, indicating the donor's name and address and the total amount, in the party's annual statement of accounts. Individual donations of more than $50000 €$ must be reported immediately to the President of the German Bundestag and are made public in a timely manner in a parliamentary publication and at the website of the Bundestag. ${ }^{14}$ In case of illegal donations, the parties must forward them immediately to the President of the German Bundestag (sect. 25(4) PPA).

In 2017 a new problem has evolved: A private association has massively supported a certain party by canvassing, in particular by advertising in the media, and, thus, influenced the outcome of the elections - but without any formal

${ }_{11}$ See the recent analysis of the Wissenschaftliche Dienste [Research Services] of the German Bundestag, Zulässigkeit und Durchsetzbarkeit von Mandatsträgerbeiträgen [Admissibility and enforceability of contributions by elected office-holders], 17/06/2016. Available: www.bundestag.de/blob/43 6786/7ed47fbbde5ead78c5ddff1lec78be3a/wd-3-155-16-pdf-data.pdf [last viewed 17.06.2019], with further references. See also Kühr, $H$. Legalität und Legitimität von Mandatsträgerbeiträgen [Legality and legitimacy of contributions by elected office-holders], 2014 (with a proposal for a more detailed regulation).

12 In the most spectacular scandal even the former Federal Chancellor Helmut Kohl was involved, see Aleman, U. von. Party Finance, Party Donations and Corruption. The German Case. In: Transparency International (ed.). La Pietra Meeting Papers, Prohibiting Bribe Payments to Foreign Political Parties, 2001, p. 23 ff. Available: www.phil-fak.uni-duesseldorf.de/fileadmin/Redaktion/ Institute/Sozialwissenschaften/Politikwissenschaft/Dokumente/Alemann/01_alemann_partyfinance-n-corrupt-exchange.pdf [last viewed 17.06.2019].

13 See on illegal donations received in 2017 by a radical right-wing populist party the reports of Spiegel Online, 19/11/2018. Available: www.spiegel.de/international/germany/alternative-for-germanyparty-hit-by-donation-scandal-a-1239203.html [last viewed 17.06.2019], and Deutsche Welle, 20/11/2018. Available: www.dw.com/en/afd-donor-scandal-weidel-under-official-investigation/a46384979[last viewed 17.06.2019].

14 Cf. for 2018 the special website at www.bundestag.de/parlament/praesidium/parteienfinanzierung/ fundstellen50000/2018 [last viewed 17.06.2019]. 
cooperation or contact. The origins of the financial resources of this association are unclear. It is now discussed if such activities should be considered as concealed party donations. For future elections, new regulations will be necessary.

\subsection{Revenues from Other Activities}

$\$ 24(4)$ lists other potential sources of private party funding, such as business activities, shares in companies, other assets, organising events, the sale of materials and publications and others. These sources are not unimportant since the total amount of all revenue generated by the party itself represents the relative upper limit for the complementing partial general direct public funding of the party (cf. supra, 2., and infra, 4.2). A right-wing populist party used a shortcoming in the law and started to trade in gold, with little profit but a high turnover. As a sign of protest, subsequently a German satire party started to sell $100 €$ bills for $80 €$. After an amendment of the Political Parties Act, nowadays not the turnover but the profit is taken into account (cf. sect. 19a(4) phrase 2 PPA) and business activities with no or little profit are not attractive anymore.

\section{Partial Public Funding of Political Parties}

\subsection{Indirect Public Funding through Income Tax Reductions on Membership Fees and Donations}

The state supports the political parties indirectly by the way of tax reductions. The Federal Constitutional Court has formulated requirements with regard to the principal of equal opportunities of political parties: The tax reductions must not favour parties that are attracting tax payers with higher income and there must not be tax deductions for donations by companies or other legal persons. ${ }^{15}$

The current system allows in sect. $34 \mathrm{~g}$ of the Income Tax Act for a 50 percent tax reduction, up to an upper limit of $825 €$, for the expenses for membership fees and donations. Furthermore, it allows in sect. $10 \mathrm{~b}(2)$ Income Tax Act for a deduction of higher expenses, up to $1650 €$, from the taxable base. There is still the problem that this last mechanism favours tax payers with a higher income, due to the system of progressive income taxation in Germany. However, with regard to the rather low upper limit, the distortion is not significant.

\subsection{Direct Public Funding}

The direct public funding of the political parties for their activities in general is regulated in a complicated manner in sect. 18 et seq. PPA. Every year, the President of the German Bundestag will determine the funds and allocate them to the eligible parties based on their annual statement of accounts (see infra, 5.2.). In this capacity, he acts as a public authority; his decisions can be challenged before the administrative courts. There is an annually adjusted limit for the financing of all parties in total (absolute upper limit). For 2019 it has been set at 190 million $€$ (cf. sect. 18(2) PPA). Furthermore, there is the already mentioned limit for the funding of the individual party, as required in the jurisprudence of the Federal Constitutional Court (the relative upper limit): The amount of direct public funding must not exceed the revenue generated by the party itself in the way of private funding (cf. sect. 18(5) PPA).

\footnotetext{
15 Federal Constitutional Court, judgement of 09/04/1992, 2 BvE 2/89, BVerfGE 85, 264(313, 315).
} 
Concerning the allocation criteria, the success of the party in the parliamentary elections (on the European, national and Land level) and the revenues from membership fees, office-holder contributions and donations are decisive (the income from other sources of private funding is only relevant for the calculation for the relative upper limit).

\subsubsection{Funding Per Vote}

According to sect. $18(3,4)$ PPA each party shall receive an annual amount of $0.83 €$ per vote for the respective party list (1.00€ for the first 4 million votes). However, this only applies if the party gained at least 0.5 percent of the votes at the last European or national elections or 1.0 percent at a Land election. Promising money per vote (and not per percentage of votes), the Political Parties Act nowadays motivates the parties to strive for a higher election turnout: They may receive higher funding even with a lower percentage of votes if in total more citizens have voted for them. In times of disenchantment with politics and low citizens participation at the election this may be helpful to stabilise a vivid democracy. Concerning the threshold of 0.5 percent of the votes, this obstacle is not as harmless as it appears: Most of the parties that participated in the federal elections in 2017 did not fulfil this requirement. ${ }^{16}$

\subsubsection{Funding Per Contribution}

In addition to the funding per vote each party shall receive an annual amount of $0.45 €$ for each euro acquired as membership fee, office-holder contribution or lawfully (!) obtained donation. However, in this context, only donations of natural persons and only donated amounts of up to $3300 €$ per person will be taken into account. Donations of larger amounts are legal but will not result in higher direct public funding.

\subsection{Since 2017: Exclusion of Parties Seeking to Undermine or Abolish the Free and Democratic Constitutional Order}

Under art. 21(2) BL political parties actively seeking to undermine or abolish the free and democratic constitutional order shall be unconstitutional and may be prohibited by the Federal Constitutional Court. In reaction to a controversial judgement of January 2017 denying the prohibition of a right-wing extremist party because it assessed this party too unimportant to be considered as a threat, ${ }^{17}$ art. $21 \mathrm{BL}$ has been amended. Under the new art. 21(3,4) BL such parties, even if not prohibited, shall be excluded from public funding by decision of the Federal Constitutional Court. According to sect. 46a of the Federal Constitutional Court Act, the Court shall declare the party excluded for the duration of six ears. Thus, the fight of the extremist parties against the free and democratic constitutional order is at least not financed by the state anymore. In case of such an exclusion also the favourable fiscal treatment of the party and of payments made to it will cease.

16 See the official final result, as published by the Bundeswahlleiter. Available: www.bundeswahlleiter.de/en/info/presse/mitteilungen/bundestagswahl-2017/34_17_endgueltiges_ergebnis. html [last viewed 17.06.2019].

17 Cf. Federal Constitutional Court, judgement of 17/01/2017, 2 BvB 1/13, BVerfGE 144, 20. English translation available: www.bundesverfassungsgericht.de/SharedDocs/Entscheidungen/ EN/2017/01/bs20170117_2bvb000113en.html [last viewed 17.06.2019]. 


\section{Financial Accountability of Political Parties}

The German party funding law is not limited to the regulation of the various sources of private and public party funding. It places special emphasis on the financial accountability of the parties, with complicated rules and procedures that are difficult to understand even for the expert and, thus, have led to numerous attempts of the parties to evade them.

\subsection{Striving for Transparency: Constitutional Obligation to Publicly Account for Sources and Use of Funds and for Assets}

Art. 21(1) phrase $4 \mathrm{BL}$ obliges the political parties to publicly account for their sources and the use of their funds and for their assets. Thus, the German constitution thrives for transparency, as a precondition for a fair and undistorted democratic process. In particular, any entanglement of political and economic interests shall be disclosed. Besides, the internal organisation of the parties shall be protected against undemocratic influences (by oligarchs etc.) as they are widespread in the East European democracies.

\subsection{Current Concretisation of Accountability in the Political Parties Act}

The accountability of the political parties is concretised in detailed provisions in sect. 23 et seq. PPA, with even a special part on penal provisions and procedures in case of inaccurate accounting in sect. 31a et seq. PPA.

Every party is obliged to submit for each calendar year a correct and exhaustive public statement of accounts (sect. 19a, 23 et seq. PPA). This statement must be audited by a certified auditor and accompanied by an audit report and, if the audit does not give any reason for objections, an auditor's certificate (sect. 23(2), 30 PPA). The annual public statement of accounts must be submitted to the President of the German Bundestag until September of the following year. If it is submitted late, there will be no funding per contribution. If it is not submitted until the end of the year, there will be no direct funding at all (sect. 19a(2) PPA).

The President of the German Bundestag will scrutinise the party's statement of accounts thoroughly regarding its form, content and correctness (cf. sect. 23a PPA). Often the statements of accounts prove to be deficient.

For the case of illegal donations or incorrectness of the statement of accounts the Political Parties Act provides for sanctions (cf. sect. 31a et seq.). Parties must reimburse funds wrongly granted to them due to wrongfully listed contributions or donations. In case of donations of more than $10000 €$ that have not been stated correctly or other inaccuracies in the statement of accounts, twice the corresponding amount will be reduced from their public funding. In case of illegally accepted donations that have not been immediately forwarded to the President of the German Bundestag, the parties lose triple the corresponding amount. Furthermore, there is criminal liability in case of (intentionally) incorrect statements or undue splitting of donations for the accounting.

\section{Summary}

The German party funding system may appear well-elaborated and wellengineered after its many reforms and adjustments but there are still deficiencies. Since there is no absolute limit for donations, not even for those from companies, financially privileged citizens and big companies can distort the free competition 
between the political parties by individual donations of very high amounts which create an unjustifiable significant advantage. The donors may not profit from corresponding tax advantages but they still can exert influence. Furthermore, the sanctions in case of accepting illegal donations or not informing correctly and in time about bigger donations are rather soft. To reduce triple the corresponding amount in case of not listed donations of more than $10000 €$ and five times the corresponding amount in case of donations of more than $50000 €$ not reported to the President of the German Bundestag would provide for a better motiviation of the parties to respect the law. Finally, there is still a lack of transparency - at least of transparency at the right time: Since the parties do not need to submit their annual statement of accounts before September of the following year they are not obliged to disclose donations of amounts between $10000 €$ and $50000 €$ during the important time of the electoral campaign. However, what is the use of knowing one year after the elections about the donors of the party?

In 2009, the Council of Europe's Group of States against Corruption (GRECO), an institutionalised working and expert group with representatives of 48 European countries, published an Evaluation Report on Germany on Transparency of Party Funding, in which it submitted a number of recommendations for achieving more transparency. ${ }^{18}$ In a new document of 2017 GRECO criticised that some recommendations had not been and some others had not been satifactorily implemented. ${ }^{19}$ GRECO proposes to lower all the presented thresholds for party donations (cf supra, 3.3). The group urges in particular to lower the $50000 €$ threshold for the immediate reporting and disclosure of donations. Furthermore, it presses for enhancing the transparency of direct donations to parliamentarians and election candidates who are members of political parties, and for (further) increasing of the resources available to the President of the German Bundestag for supervising party funding. These recommendations of a prominent monitoring group of the Council of Europe document that in the eyes of the experts in Europe the German party funding system is still far from perfect.

\section{Sources}

\section{Bibliography}

1. Aleman, U. von. Party Finance, Party Donations and Corruption. The German Case. In: Transparency International (ed.). La Pietra Meeting Papers, Prohibiting Bribe Payments to Foreign Political Parties, 2001, p. 23 ff. Available: www.phil-fak.uni-duesseldorf.de/fileadmin/Redaktion/Institute/ Sozialwissenschaften/Politikwissenschaft/Dokumente/Alemann/01_alemann_party-finance-ncorrupt-exchange.pdf [last viewed 17.06.2019].

2. Blumenberg, M. S., Nassmacher, K.-H., Onken, H. Germany: current issues of an aging party finance regime. In: J. Mendilow, E. Phélippeau (eds.). Handbook of Political Party Funding, 2018.

3. Council of Europe, Group d'Etats contre la corruption [Group of States against corruption] (GRECO): Addendum to the Second Compliance Report on Germany. Incriminations - Transparency of Party Funding, 2018. Available: www.coe.int/en/web/portal/-/anti-corruption-group-says-that-germanystill-lags-in-efforts-to-make-party-financing-more-transparent [last viewed 17.06.2019].

18 GRECO. Third Evaluation Round: Evaluation Report on Germany on Transparency of Party Funding, 2009, No. 123. Available: https://rm.coe.int/16806c6362 [last viewed 17.06.2019].

19 GRECO. Addendum to the Second Compliance Report on Germany. Incriminations - Transparency of Party Funding, 2018, No. 28 ff, in particular No. 37. Available: www.coe.int/en/web/portal/-/ anti-corruption-group-says-that-germany-still-lags-in-efforts-to-make-party-financing-moretransparent [last viewed 17.06.2019]. 
4. Council of Europe, Group d'Etats contre la corruption [Group of States against corruption] (GRECO): Third Evaluation Round: Evaluation Report on Germany on Transparency of Party Funding, 2009. Available: https://rm.coe.int/16806c6362 [last viewed 17.06.2019].

5. Deutsche Welle (ed.). DW exclusive: How German companies donate secret money to political parties, 2017. Available: www.dw.com/en/dw-exclusive-how-german-companies-donate-secretmoney-to-political-parties/a-40610200 [last viewed 17.06.2019].

6. German Bundestag (ed.). State funding of political parties in Germany, last revised 2012. Available: www.bundestag.de/blob/189744/554b4eaa7746b48ef31612792a9cf461/party_funding_05-data.pdf [last viewed 17.06.2019].

7. Law Library of Congress (ed.). Campaign Finance: Germany, last updated 2015. Available: www.loc. gov/law/help/campaign-finance/germany.php [last viewed 17.06.2019].

\section{Normative Acts}

1. Grundgesetz für die Bundesrepublik Deutschland [Basic Law for the Federal Republic of Germany] of 23/05/1949. Available: www.gesetze-im-internet.de/gg, English translation at www.gesetze-iminternet.de/englisch_gg/index.html [last viewed 17.06.2019].

2. Gesetz über die politischen Parteien (Parteiengesetz) [Act on Political Parties (Political Parties Act)]. Available: www.gesetze-im-internet.de/partg/index.html [last viewed 17.06.2019].

3. Gesetz über das Bundesverfassungsgericht (Bundesverfassungsgerichtsgesetz) [Act on the Federal Constitutional Court (Federal Constitutional Court Act)]. Available: www.gesetze-im-internet. de/bverfgg, English translation at www.gesetze-im-internet.de/englisch_bverfgg/index.html [last viewed 17.06.2019].

\section{Case Law}

1. Federal Constitutional Court, judgement of 24/06/1958, 2 BvF 1/57, BVerfGE 8, $51(63 \mathrm{ff})$ [= Decisions of the Federal Constitutional Court, vol. 8, p. $51 \mathrm{ff}]$.

2. Federal Constitutional Court, judgement of 19/07/1966, 2 BvF 1/65, BVerfGE 20, 56.

3. Federal Constitutional Court, judgement of 09/04/1992, 2 BvE 2/89, BVerfGE 85, 264.

4. Federal Constitutional Court, judgement of 09/04/1992, 2 BvE 2/89, BVerfGE 85, 264.

5. Federal Constitutional Court, judgement of 17/01/2017, 2 BvB 1/13, BVerfGE 144, 20.

\section{Other Sources}

1. Bundeswahlleiter [Federal Returning Officer] with detailed information in English on elections and political parties in Germany. Available: www.bundeswahlleiter.de [last viewed 17.06.2019]. 


\title{
"The Political Platform of the Latvian People's Council" of 17 November 1918 as the Founder of the Gender Equality Tradition in Latvia Within the Discourse of European Ideas on Gender Equality
}

\author{
Dr. iur. Sanita Osipova \\ Faculty of Law, University of Latvia \\ Professor at the Legal theory and History Department \\ E-mail: sanita.osipova@lu.Iv
}

\begin{abstract}
The paper focuses on gender equality tradition in Latvia within the discourse of European ideas on gender equality, researching the avenues whereby the political forces decided to give women a political rights at the time of establishing the Republic of Latvia. The analysis leads to a conclusion that the Republic of Latvia joined the group of countries - trailblazers, which at the end of World War I, in establishing, transforming or restoring their statehood, founded a state with a democratic structure and legally enshrined civil society, recognising women as its members with full political rights. The author also challenges a thesis that the society, even after women have been granted full political rights by law, is not in a hurry to change gender statuses and the model of the family.
\end{abstract}

Keywords: the gender equality, women's rights, political rights, marriage law, family law.

\section{Contents}

Introduction . . . . . . . . . . . . . . . . . . . . . . . . . . . . . 97

1. Legal Status of Women in the Russian Empire . . . . . . . . . . . . . . . . . . . . 97

2. Development of Gender Equality Idea . . . . . . . . . . . . . . . . . . . . . 99

3. Establishment of Gender Equality in Political Rights in the Republic of Latvia . . . . . . 101

4. Establishment of Gender Equality in Marriage Law in the Republic of Latvia . . . . . . 103

Summary. . . . . . . . . . . . . . . . . . . . . . . . . . . . . . 106

Sources . . . . . . . . . . . . . . . . . . . . . . . . . . . . . . . . . . . . . . . 107

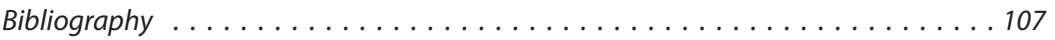

Normative Acts . . . . . . . . . . . . . . . . . . . . . . 108

Draft Laws and Other Sources . . . . . . . . . . . . . . . . . . . . . 108 


\section{Introduction}

Over the past 50 years, extensive studies of the history of gender equality have been conducted in Europe; however, in Latvia this issue remains almost unresearched. ${ }^{1}$

This might be due to the fact that significant problems in gender equality issues are not encountered in Latvia, since the Soviet law, which was in force in the territory of Latvia from 1940 until very $1990^{2}$, envisaged gender equality both in political rights and civil law, and it was implemented with a strong hand. ${ }^{3}$ The former 'socialist countries' experienced gender quotas in various state and private structures, which are currently discussed by the 'old' European states, already during the years of the Soviet state. This article explores the foundations of gender equality that were laid in establishing the Republic of Latvia in 1918, examining this theme in comparative discourse of the gender equality genesis throughout Europe.

The statuses of genders and the institution of the family are the foundations of every society, and, being fundamental values, remain very conservative and persistent in their unchangeability. And yet, the $20^{\text {th }}$ century turned into the time when gender equality was legalised, followed by deep changes in the life of society. ${ }^{4}$ Therefore, it is important to identify the causes of this process in 'Europe, the continent of nations'.

Until the $20^{\text {th }}$ century, the traditional legal culture of European nations was basically founded upon the Christian faith and local customs, wherein gender inequality and patriarchal family were reinforced in different variations, with the husband as 'the head of the family' and the wife being legally capable, but having a restricted legal competence to act. However, these restrictions or limits on a woman's competence to act differed not only in different states and for different nations, but sometimes also among people belonging to the same nation, but to different classes. The understanding of differential legal competence to act depending on gender traditionally was rooted in the division of labour between genders and the ideas regarding mental and physiological capacities pertaining to each gender. An illustration thereof is an excerpt from a law applied in the territory of Latvia provided below.

\section{Legal Status of Women in the Russian Empire}

In the $19^{\text {th }}$ century and at the beginning of the $20^{\text {th }}$ century, uniform civil law did not exist on the territory of the Republic of Latvia, which belonged to the Russian Empire, and the particularism of law was not abolished immediately after establishment of Latvian State in 1918. In Latgale, the eastern part of Latvia, Book 1 of Volume X of the Collection of Law of the Russian Empire (Svod zakonov Rossijskoj imperii, 1832, hereinafter - CLRE) was in force, while in Vidzeme and Kurzeme - Part III of the Collection of Local Laws of the Baltic Provinces

1 There are few studies on women rights, but they have not been published by legal scientists, but by historians, for example, doctoral thesis from Stikāne, V. Sieviete Livonijas sabiedrībā viduslaikos un jauno laiku sākumā 13.-16. gs. [Woman in Livonian Society in the Middle Ages and Early Modern Times 13-16 Century]. Riga: University of Latvia, 2012.

2 Except the period of German occupation - 1941-1944.

3 König, R. Familiensoziologie. Berlin, Heidelberg: Springer-Verlag, 2013, pp. 140-141.

4 For example, Aralovec, N. Gorodskaja semja v Rossiji, 1927-1959 gg. [The urban family in Russia, 1927-1959]. Tula: Grif i K, 2009, pp. 154-155. 
(hereinafter - Bunge's Collection). ${ }^{5}$ The differences in law were not only territorial; they also extended to representatives of different classes, religions and ethnicities residing on the same territory. The diversity in marriage law was influenced by the fact that in the Russian Empire, similarly to the majority of European states of that time, the conclusion of a marriage and a divorce remained in the competence of the church instead of the state. Latvians and Baltic Germans predominantly belonged to Catholic and Lutheran denominations, a smaller part of Latvians and Russians were Orthodox.

The civil law, referred to above, that society abided by, was intended for a religious, patriarchal, class society. ${ }^{6}$ Pursuant to Bunge's Collection, the compilation of legal norms by Friedrich Georg von Bunge (1802-1897), in compliance with the perceptions held by the German historical school of law on the nature of law, which society adhered to at the time of drafting the law (the mid- $19^{\text {th }}$ century), ${ }^{7}$ a husband was the advisor and guardian of a wife (8.5.), whom the wife was not allowed to leave without his permission $(8.2,8.3)$. The husband had the right to determine the family's place of residence, and he managed his wife's property and publicly defended her rights, inter alia, in court (8.5) ${ }^{8}$ The only restriction upon a husband's power over his wife was the requirement to the husband to exercise his right over the wife 'in good faith'. In Latgale the rights and obligations of spouses were regulated by article 100-118 of Chapter 4, Book I, Volume X of CLRE, which also consolidated the husband's power; however, here the wife had a broader legal competence to act, i.e., a married woman without her husband's permission was not allowed to assume only the commitments of a promissory note or to conclude an agreement of personal servitude, yet, the wife had the right to assume other commitments. ${ }^{9}$ Moreover, the limits of a woman's legal competence to act were influenced by the property relationships between the spouses and the right to handle her own property. The understanding of the basis of spouse's property relationships significantly differed among representatives of different classes; for example, the presumption of spouses' joint ownership of property was in force in the cities of Vidzeme, whereas "the laws that are in force establish partially different joint ownership of property - pure Roman condominium - for the rural nonaristocratic clergy of Vidzeme", but according to Vidzeme peasant laws, special joint ownership of property has been established, which only outwardly unites property in one totality, transferring under the management of the husband... This type of joint ownership remains in force only during the marriage, and

5 Vēbers, J. Ģimenes tiesības Latvijā. No neatkarīgas Latvijas valsts nodibināšanas 1918. gadā līdz neatkarības atjaunošanai 1991. gadā [Family law in Latvia. From the creation of an independent Latvian state in 1918 to the restoration of independence in 1991]. In: Latvijas Republikas Civillikuma komentāri. G̦imenes tiesības. Rīga: Mans Īpašums, 2000, p. 112.

6 Svod grazhdanskih uzakonenij gubernij Pribaltijskih (Chastj III Svoda mestnih uzakonenij gubernij Ostzejskih) [The Code of Civil Laws of the Baltic Provinces (Part III of the Code of Local Laws of the Ostsee provinces)]. Petrograd: Pravo, 1915, pp. 17-18.

7 Jarvelaids, P. Baltijas civiltiesību "tēvs" Frīdrihs Georgs fon Bunge [Baltic Civil Law "father" Friedrich Georg von Bunge]. Jurista Vārds, No. 44/45(846/847), 2014. Available: http:// www.juristavards.lv/doc/199956-baltijas-civiltiesibu-tevs-fridrihs-georgs-fon-bunge/ [last viewed 21.02.2019].

8 Svod grazhdanskih uzakonenij gubernij Pribaltijskih (Chastj III Svoda mestnih uzakonenij gubernij Ostzejskih) [The Code of Civil Laws of the Baltic Provinces (Part III of the Code of Local Laws of the Ostsee provinces)]. Petrograd: Pravo, 1915, p. 18.

9 Eljaševss, D. Sievietes zvērinātā advokatūrā [Women as attorneys]. Tieslietu Ministrijas Vēstnesis, No. 3, 1933, p. 52. 
following the death of one of the spouses' splits into its elements... In the rural and urban law of Kurzeme, even though spouses' separate ownership of property is recognised, similarly as in the case of joint property, it is under the husband's unaccountable management and use ... In Latgale, in accordance with the customary law, completely separated ownership of spouses' property existed. ${ }^{10}$

Thus, obviously, in the territory of future Latvia, different legal variations with regard to the totality of a husband's power of the wife and her property could be discerned; however, one thing is clear - in all these traditions the woman is unequal and subjected to the husband's power and guardianship.

\section{Development of Gender Equality Idea}

It is important to identify, how the traditions of gender inequality, embedded for centuries, if not for millennia and supported by the church, was broken. The school of natural law began creating the ideological foundations for the human equality, defending the value, liberty and equality of every human being, the values that starting with the end of the $18^{\text {th }}$ century, have been laid as the foundation of human rights. ${ }^{11}$ The first political achievements in implementing the ideas of the school of natural law brought full-fledged equality of all men in the USA ${ }^{12}$ and France. ${ }^{13}$ However, at the same time the voices of first activists taking the stance for women's rights resounded. During the time of the French Revolution Olympe de Gouges (1748-1793) published the draft "Declaration of the Rights of Woman and the Female Citizen", which provided that a woman had also been born free and in her rights was equal to a man. ${ }^{14}$ However, the National Convention rejected the submitted draft in 1791. The public opinion and even the most enlightened minds were not yet ready to profoundly re-examine the foundations of the society's structure. $^{15}$

The demand for gender equality was expressed loudly and aggressively a couple of generations later, in the second half of the $19^{\text {th }}$ century, but especially so at the beginning of the $20^{\text {th }}$ century, with the growing popularity among the masses of the new legal-philosophical position - Marxism. Karl Marx (1818-1883) clearly expounded his opinions already in "The Communist Manifesto", published in 1848; however, these political ideas gained broader political response only after his death, in particular, in the $20^{\text {th }}$ century. ${ }^{16}$ Marxists stood for actual equality in society, including gender equality. Marxists demand emancipation of women. They considered divorce, in turn, as a woman exiting the power of her husband, a

10 Bukovskis, V. Jaunā civilkodeksa izstrādāšanas darbība [The Development of the new Civil Code]. Tieslietu Ministrijas Vēstnesis, No. 1, 1921, pp. 32-40.

11 Horn, N. Einführung in die Rechtswissenschaft und Rechtsphilosophie. 4. Auflage. Heidelberg: C. F. Müller, 2007, S. 99.

12 Armitage, D. The Declaration of Independence: A Global History. Harvard: Harvard University Press, 2009, pp. 166-167.

13 Schlosser, H. Grundzüge der Neueren Privatrechtsgeschichte. Rechtsentwicklung im europäischen kontext. 10. Auflage. Heidelberg: C. F. Müller, 2005, S. 129.

14 Gouges, O. de. The Declaration of the Rights of Women (September 1791). Available: https://chnm. gmu.edu/revolution/d/293/ [last viewed 21.02.2019].

15 Mousset, S. Women's Rights and the French Revolution: A Biography of Olympe De Gouges. New Brunsvick, London: Transaction Publishers, 2007, pp. 46-50.

16 Horn, H. Einführung in die Rechtswissenschaft und Rechtsphilosophie. 4. Auflage. Heidelberg: C. F. Müller, 2007, p. 210. 
pre-requisite of woman's emancipation. ${ }^{17}$ In "Manifesto of the Communist Party" by Karl Marx and Friedrich Engels (1820-1895) marriage was clearly labelled as an institution that allows a man - the husband - to exploit a woman - the wife. "Manifesto of the Communist Party" explains:

On what foundation is the present family, the bourgeois family, based? On capital, on private gain...The bourgeois sees in his wife a mere instrument of production. He hears that the instruments of production are to be exploited in common, and, naturally, can come to no other conclusion than that the lot of being common to all will likewise fall to the women. He has not even a suspicion that the real point is to do away with the status of women as mere instruments of production. ${ }^{18}$

Moreover, Friedrich Engels initially believed in 'a utopia': that in the communistic society of equals not only the state and the law, but also the marriage and the family would disappear in the course of time. Later Marxist classics reviewed this idea, noting that only the nature of marriage would undergo significant change. It would become a union of two free, equal persons, based upon love and mutual respect. ${ }^{19}$ Today we can consider whether this dream has become true in the model of contemporary family. At least legally, all pre-requisites have been created in the law of European states for it to be so.

At the turn of the $19^{\text {th }}$ and $20^{\text {th }}$ centuries, socialists became a notable political power in Europe, including the Russian Empire. These predominantly were intelligentsia, who spoke in a language that was understandable to working people and called for the abolition of historical injustice, namely, that one part of society owned everything, but the other - nothing. Socialist ideas were also very popular among Latvians, the majority of which for centuries had been serfs of Baltic German landlords and only after abolishment of serfdom in the course of the $19^{\text {th }}$ century acquired their personal freedom and the rights to settle in cities. ${ }^{20}$

One of the first socialists' demands in promoting women's equal rights was the demand to grant women full political rights, the second demand for emancipation of women - to grant women the right to demand divorce. ${ }^{21}$ In the majority of European countries, also in the Russian Empire, divorce was an extraordinary measure, since even at the beginning of the $20^{\text {th }}$ century in our state 0.029 marriages per 1000 people were divorced annually. ${ }^{22}$ In Russia, both liberals, who defended a person's right to freedom and self-determination, and socialists, who considered that the existing law discriminated against woman and made her a property of her

17 Dekret o rastorzheniji braka ot 16(29) dekabrja 1917 goda [Decree on divorce, December 16(29), 1917]. In: Dekreti Sovetskoj vlastji. Moskva: Directmedia, 2016, pp. 237-238.

18 Marx, K., Engels, Fr. Das Manifest der Kommunistische Partei. Zittau: Berndt Müller Verlag, 2009, S. 45 .

19 Dekret o rastorzheniji braka ot 16(29) dekabrja 1917 goda [Decree on divorce, December 16(29), 1917]. In: Dekreti Sovetskoj vlastji. Moskva: Directmedia, 2016.

20 Lazdiņš, J. Baltijas zemnieku privāttiesības (XIX gs.) [Civile law of the Baltic peasants (XIX century)]. Riga: Biznesa augstskola “Turība”, 2000, pp. 68-69.

21 For example: Aspazija. Runa Satversmes sapulces 10. decembra sēdē [Speech at the meeting on December 10 of the Constitutional Assembly]. Sociāldemokrāts, No. 285, 1920, p. 1.

22 Mironov, B. Socialnaja istorija Rossiji perioda imperiji (XVIII - nachalo XX vv.): genezis lichnosti, demokraticheskoj semji, grazhdanskogo obshchestva i pravovogo gosudarstva [The social history of Russia during the empire (XVIII - early XX centuries): the genesis of the individual, the democratic family, civil society and the rule of law]. Sankt-Peterburg: izdatelstvo Dm. Bulanin, 1999, Vol. 1, p. 176. 
husband and an object of exploitation, had unsuccessfully advocated liberalisation of divorce since the end of the $19^{\text {th }}$ century. ${ }^{23}$

Unequivocally, political gender equality was introduced in Europe to a large extent thanks to the popularity of socialists among masses and their active political fight for women's voting rights. Socialist ideals were expressed by various political forces, among which social democrats and communists were the most striking. ${ }^{24}$

Finland was the first European state to grant women general voting rights in 1906. At this time, Finland was a province of the Russian Empire with limited autonomy. ${ }^{25}$ On the other hand, conservative Lichtenstein was the last among European states to grant the voting right to women - only in $1984 .{ }^{26}$ A certain legal paradox developed, since in many European countries women had been granted full political rights already at the beginning of the $20^{\text {th }}$ century, while the restrictions upon full civil rights, especially in family law were retained. Moreover, a trend could be observed that when new states were established, political forces were more open to change, including reviewing the social status of genders, compared to old and stable states. After establishment of the new state and stabilisation of situation the society, at least partially, returned to the old values and traditional understanding of gender statuses, especially within the family, as shown by the example of the Republic of Latvia.

\section{Establishment of Gender Equality in Political Rights in the Republic of Latvia}

The Republic of Latvia joined the group of countries - trailblazers, which, at the end of World War I through establishing, transforming or restoring their statehood founded a state with a democratic structure and legally enshrined civil society, recognising women as its members with full political rights. At the time when the Republic of Latvia was established, social democrats were an important political force, they represented both at the People's Council and later - at the Constitutional Assembly. Four representatives of the Latvian Social Democratic Workers' Party (LSDPS) and three representatives of the Latvian Revolutionary Socialists' Party participated in the founding sitting of the People's Council. ${ }^{27}$

Socialists together with liberals laid the legal foundations for political equality of genders in establishing the Republic of Latvia. The "Political Platform of Latvian People's Council", adopted on 17 November 1918, envisaged: "The members of the

23 Mironov, B. Socialnaja istorija Rossiji perioda imperiji (XVIII - nachalo XX vv.): genezis lichnosti, demokraticheskoj semji, grazhdanskogo obshchestva i pravovogo gosudarstva [The social history of Russia during the empire (XVIII - early XX centuries): the genesis of the individual, the democratic family, civil society and the rule of law]. Sankt-Peterburg: izdatelstvo Dm. Bulanin, 1999, Vol. 1, p. 176.

24 Fischer, I. Zur Problematik der Erfassung von Aktengut zu Gender- und Frauengeschichte im Archiv der sozialen Demokratie. Available: http://www.fes.de/archiv/adsd_neu/inhalt/recherche/ frauenbestand/text.htm [last viewed 26.02.2019].

25 Korppi, A. A Long Tradition of Equality: Women's Suffrage in Finland. In: The Straggle for Female Suffrage in Europe: Voting to Become Citizens. B. Rodriguez-Ruiz, R. Rubio-Marin (eds.). LeidenBoston: Brill, 2012, pp. 47-60.

26 Rommelanger, U. Das konsultative Referendum. Berlin: Duncker \& Humbolt, 1988, S. 30.

27 Blūzma, V. Latvijas Republikas valsts dibināšana un nacionālās tiesību sistēmas veidošana (1918-1922) [Foundation of the Republic of Latvia and the creation of the National Legal System (1918-1922)]. In: Latvijas tiesību vēsture (1914-2000). A. Lēbers (ed.). Rỉga: fonds "Latvijas Vēsture", 2000, p. 151. 
Constitutional Assembly shall be elected, with the participation of both genders, on the basis of general, equal, direct, secret and proportional voting rights." 28

This political decision, which currently in the Latvian legal doctrine is viewed as a fundamental legal norm of this state, broke the tradition of gender inequality and instituted the foundations for new gender statuses in society. Women immediately exercised their full rights, and the first female politicians were active already in the People's Council, ${ }^{29}$ for example, Klāra Kalniṇa (1874-1964) from LSDSP. ${ }^{30}$

"The Law on Electing the Constitutional Assembly of Latvia", adopted in 19 August 1919, consolidated the principle referred to above, envisaging that the Constitutional Assembly was to be elected in general, equal, direct, secret and proportional elections (Article 1), with the participation of Latvian citizens of both genders, who had reached the age of 21 and were residing in Latvia. ${ }^{31}$ Such electoral qualifications (equality, relinquishing the privileges of classes and property-based qualification, gender equality) were a 'fashionable trend' in the European state law at the beginning of the $20^{\text {th }}$ century.

Latvian women actively exercised their active and passive election rights and participated in the shaping of the new state. Out of 164 members elected to the Constitutional Assembly or the constitutional legislator six were women: ${ }^{32}$ Valèrija Seile (Latgale Farmer's Party, born in 1891, a Latvian, higher education, inspector at Rēzekne primary school) ${ }^{33}$, Aspazija-Pliekšāne Elza (Latvian Social Democratic Workers' Party, hereinafter - LSDSP, born in 1865, a Latvian, secondary school education, a poet), ${ }^{34}$ Berta Vesmane (LSDSP, born in 1878 , a Latvian, completed commerce courses in Petersburg), ${ }^{35}$ Klāra Kalniṇa (LSDSP, a Latvian, higher education, a dentist), ${ }^{36}$ Zelma Cēsniece-Freidenfelde (Non-party group, born in 1892, a Latvian, higher education, a doctor) ${ }^{37}$ and Apolonija Laurinoviča (Latgale Farmers' Party, born in 1886, a Latvian, secondary school education, a student). ${ }^{38}$ In general, the ladies at the Constitutional Assembly were better educated than their colleagues - the average gentlemen, as a half of them had higher education. Poet Aspazija was the oldest, with the greatest experience in public life, as well as

28 1918. gada 17. novembra "Latvijas Tautas Padomes politiskā platforma" ["Political Platform of the Latvian National Council” of November 17, 1918]. In: Latvijas Tautas Padomes sēdes. Vol. 1. Rīga: Satversmes Sapulce, 1920, pp. 6-7.

29 In the People's Council mandates were not linked to concrete persons. Each party had a concrete number of seats in the Council, which were filled by persons authorised by the party, and they changed frequently. There were 183 seats in the People's Council; however, accurate total number of members is not known, two numbers are mentioned - 245 and 297. Regretfully, no research has been conducted to identify all women, who were active in the People's Council.

30 Deputātu personu rādītājs [List of Deputies]. In: Latvijas Satversmes sapulces stenogrammu rādìtājs. H. Kārkliņš (ed.). Rìga: Latvijas Republikas Saeima, 1925, p. 75.

31 1919. gada 19. augusta Latvijas Tautas Padomes "Latvijas Satversmes sapulces vēlēšanu likums" [The law on elections to the Constitutional Assembly of Latvia of August 19, 1919]. In: Latvijas Pagaidu Valdības Likumu un Rīkojumu krājums. Rīga: Valsts kanceleja, 1919, p. 124.

32 Latvijas Satversmes Sapulces deputātu saraksts [List of deputies of the Constitutional Assembly of Latvia]. In: Latvijas Satversmes Sapulces stenogrammu izvilkums (1920-1922). Rīga: Tiesu namu aǵentūra, pp. 1102-1107.

33 Deputātu personu rādītājs [List of Deputies]. In: Latvijas Satversmes sapulces stenogrammu rādītājs. H. Kārkliņ̌s (ed.). Rīga: Latvijas Republikas Saeima, 1925, p. 142.

34 Ibid., p. 15.

35 Ibid., p. 170.

36 Ibid., p. 75.

37 Ibid., p. 44.

38 Ibid., p. 100. 
the most recognisable among the ladies of the Constitutional Assembly. Only Klāra Kalnina had a more extensive experience in politics.

The basic task of the Constitutional Assembly, was drafting the Constitution for the state, however, alongside elaboration of the fundamental law, active legislation also took place at the Constitutional Assembly, laying the legal foundations of the new state in the state law, financial law, education and cultural law, legislation on land reform, civil law, etc. ${ }^{39}$ Members of the Constitutional Assembly not only elaborated the Constitution of the state, but also shaped the legal system of Latvia by adopting new laws that complied with the liberal and democratic nature of the new state. Thus, in assessing the activities of the Constitutional Assembly, its contribution in developing and adopting other laws, not only the Constitution, should be taken into account.

In discussing the draft Constitution, the spokespersons were almost only men - the members of the Assembly. The female members of the Assembly hardly participated in public discussion. Aspazija was an exception, she engaged in discussions on articles of Chapter II or the chapter of fundamental rights of the Constitution, commented on draft article 95, which provided for the freedom of movement, protection of citizens abroad, prohibited extradition and expulsion of citizens. The transcripts of the Constitutional Assembly record also a number of Aspazija's interjections from the floor. ${ }^{40}$

\section{Establishment of Gender Equality in Marriage Law in the Republic of Latvia}

The female members of the Assembly were initially interested in the family law. They spoke about the draft laws under discussion as equals to their male colleagues; however, in legislation women found relevance in different topics than men. The women of the Constitutional Assembly were particularly interested in creating law in the fields of marriage, labour and education law. They, in particular, Aspazija, Valērija Seile, Zelma Cēsniece-Freidenfelde and Klāra Kalniṇa commended in the newspaper Sieviete ["Woman"] in 1924: "Even though the representatives of people belong to different political parties, they all unanimously advocate a liberal marriage law, which brings new moral foundations into the relationship between a husband and a wife." ${ }^{11}$

Aspazija, discussing the draft law "On Marriage", gave an extended speech at the sitting of 10 December 1920, stating that this was one of the most important laws to be adopted by the Constitutional Assembly, since by this a law "eliminating the remnants of feudalism" was to be achieved, completing the transition from

39 Blūzma, V. Latvijas Republikas valsts dibināšana un nacionālās tiesību sistēmas veidošana (1918-1922) [Foundation of the Republic of Latvia and the creation of the National Legal System (1918-1922)]. In: Latvijas tiesību vēsture (1914-2000). A. Lēbers (ed.). Rìga: fonds "Latvijas Vēsture", 2000, pp. 155-212.

40 Aspazija. Starpsaucieni Jāṇa Purgaḷa runai vispārējās debatēs par Satversmes I daḷu IV sesijas 5. sēdē 1921. gada 28. septembrī [Interjection to Jāṇis Purgalis Speech in General Debate on Part I of the Satversme at the $4^{\text {th }}$ Session of the $5^{\text {th }}$ meeting on 28 September 1921]. In: Latvijas Satversmes Sapulces stenogrammu izvilkums (1920-1922). Rìga: Tiesu namu aǵentūra, 2006, p. 130.

41 [Without author]. Latvijas Satversmes Sapulces locekles [Members of the Constitutional Assembly of Latvia]. Sieviete, No. 5, 1924, p. 126. 
the church marriage to a civil marriage. ${ }^{42}$ "By introducing the civil marriage, we [probably, Latvian women, a note by the article's author] today receive compensation for our sufferings ...", "No, we should say to church and patriarchal patronising! ... Until now, marriage was based upon a man's domination, even though in the natural state of nations, all importance in life was placed where the mother with her child was, and was respected as such ..."43 Moreover, Aspazija, actively working in the legislative institution, passionately advocated the possibility of divorce on the basis of a unilateral application by one of the spouses: "Marriage for us is sacred, serious, it is not a toy for us. Only free people unite and separate freely, and only such marriage is sacred and ethical. I say this to you as a woman, and I say this to you as an educator of people."44 Aspazija spoke passionately, and it could not have been otherwise, at the end of the $19^{\text {th }}$ century the poet herself had gone through the complicated procedure, requesting the church to divorce her marriage to her first husband. ${ }^{45}$

The researched material allows to conclude that Latvian women wanted to acquire political equality and use it to promote civil equality, first of all, in family law, so that the wife would become an equal partner in life to the husband and were respected by him and by society. This is proven by another striking quote from Aspazija's speech: "When a man worships a woman as a goddess, this does not also mean that he respects her as a human being." 46

When speaking from the podium of the Constitutional Assembly, Aspazija used the concepts 'we' and 'you'. The proportion in the hall was not to the advantage of 'us'; however, the majority of 'you' listened and heard 'us'. This lead to the adoption of liberal law, in line with the spirit of the time, which introduced civil marriage and provided for the possibility of divorce in cases defined in law (see Chapter 5 of the law "On Marriage"). ${ }^{47}$ The church continued to have the right to conclude a marriage, if the newly-weds wished so $^{48}$ however, only the court had the jurisdiction over divorce. ${ }^{49}$ However, in liberalising the rights of spouse's vis-à-vis each other, the Constitutional Assembly did not go any further. The draft law "On Engagement, Personal and Property Relations of Married People and Inheriting Thereof", which in the same year, 1921, was submitted by the Ministry of Justice, comprised the concept of the head of the family, granting the husband the final say

42 Latvijas Republikas Satversmes Sapulces 1921. gada 1. februāra "Likums par laulību" [Marriage Law, adopted by the Constitutional Assembly of the Republic of Latvia on 1 February 1921]. Tieslietu Ministrijas Vēstnesis, No. 1/3, 1921, pp. 65-74; Latvijas Republikas Satversmes Sapulces 1921. gada 18. februāra "Likums par civilstāvokḷa aktu registrāciju [The Law on Registration of Civil Status Acts, adopted by the Constitutional Assembly of the Republic of Latvia on 18 February 1921]. Tieslietu Ministrijas Vēstnesis, No. 1/3, 1921, pp. 75-82.

43 Aspazija. Runa Satversmes sapulces 10. decembra sēdē [Speech at the meeting on December 10 of the Constitutional Assembly]. Sociäldemokrāts, No. 285, 1920.

${ }^{44}$ Kalniňšs, A. Sievietes pirmās Latvijas brīvvalsts parlamentā [Women in the Parliament during the First Free State of Latvia]. Brīvā Latvija, No. 33, 1998, p. 4.

45 Lipša, I., Neiburgs, U. Nezināmā Aspazija. Remdeni? Nekad! [Unknown Aspazija. Moderately? Never!]. TVNet, 14.03.2005. Available: https://www.tvnet.lv/6178263/nezinama-aspazija-remdeninekad [last viewed 27.02.2019].

46 Aspazija. Runa Satversmes sapulces 10. decembra sēdē [Speech at the meeting on December 10 of the Constitutional Assembly]. Sociāldemokrāts, No. 285, 1920.

47 Latvijas Republikas Satversmes Sapulces 1921. gada 1. februāra "Likums par laulïbu", pp. 65-74.

48 Article 24. The marriage ceremony makes Registry Office or any confession clerics by spouses choice.

49 Ibid. 
in common decisions of the family, for example, on the family's place of residence. ${ }^{50}$ Social democrats harshly objected to this draft. ${ }^{51}$ The draft law was not adopted, but during the period of authoritarian Latvia the institution of the head of the family was enshrined in the Civil Law of $1937 .^{52}$

Were the women's voices heard at the Constitutional Assembly? Yes, they were! The female members cooperated as colleagues with men members from their 'list', engaged in discussions with the colleagues that represented different opinions. Contemporary lawyers note that women, except Aspazija, at Constitutional Assembly had been 'quiet' or 'shy'. That is not quite true, because during the debates regarding draft Constitution, indeed, only Aspazija spoke, however, when working on draft laws, both in the committees that elaborated them and during public discussions, other members of the Constitutional Assembly actively participated, speaking both from the podium and the floor: Valērija Seile, Zelma Cēsniece-Freidenfelde and Klāra Kalniṇa. The strongest politicians and most active legislators were the female members from the LSDP 'list'. And yet, women indeed were not among the most active and prominent politicians of the time, they were not promoted for 'ministerial' offices or any other responsible management position. ${ }^{53}$ In reflection as to whether that was good or bad, the legal regulation and the juridical culture, which had brought up the first Latvian politicians, should be considered. It was a conventional, conservative, patriarchal society with fixed legal and ethical norms, with the husband being the advisor and the guardian of the wife. ${ }^{54}$ The husband spoke on behalf of the wife and had the right to demand that she submits to his will.

It is important to draw attention to the patriarchal and conservative society, in which all members of the Constitutional Assembly, men and women alike, had developed as personalities, observing the model of their parents' relationships, and in which they still lived at the time when Latvia was established. This model was retained, in a slightly liberalized version, irrespectively of women having full political rights, in 1937, when finally, a new Civil Law was elaborated and the civil norms, which had been in force in the territory of Latvia during the times of Russian Empire, became invalid. The Civil Law of 1937 did consolidate the legal position of a woman (a wife), because it released the wife from the husband's guardianship or marital power (lat. potestas maritalis) ${ }^{55}$ and provided that "both spouses have equal rights" 56 , however, the wife did not become fully equal to

50 Švarcs, F. Latvijas 1937. gada 28. janvāra Civillikums un tā rašanās vēsture [Latvian 28 January 1937 Civil Code and its drafting history]. Rīga: Tiesu namu aǵentūra, 2011, p. 81.

51 Dzilleja, K. "G̣imenes galva" ["Head of the family"]. Sociāldemokrāts, No. 76, 1929, p. 1.

52 Ibid.

53 This totally differs from the present day, when "we - women" in many fields have replaced men, closing our ranks. I agree with highly esteemed President of the State Mr. Andris Bèrzinšs, that the gender balance has been distorted in favour of women. I do not know, whether to see this a victory or a loss. In discussing these issues, male lawyers have advanced the argument that women fill those places in the labour market that are not particularly prestigious. It is sad to hear this said about courts.

54 Those ideas were in the draft law Likumprojekts par saderināšanos, laulāto l̦aužu personīgām un mantiskām attiecībām un viņu mantošanu [On Engagement, Personal and Property Relations of Married People and Inheriting Thereof]. Tieslietu Ministrijas Vēstnesis, No. 3, 1924, pp. 101-116) and later in The Civil Law Code of 1937.

55 Sinaiskis, V. Civillikuma principi un gimenes tiesības [Principles of civil law and family law]. Tieslietu Ministrijas Vēstnesis, No. 1, 1938, p. 45.

56 1937. gada 28. janvāra Latvijas Republikas Civillikums [Civil Law of the Republic of Latvia of January 28, 1937]. Rìga: Kodifikācijas nodal̦a, 1938, p. 23. 
the husband. In the case of dispute regarding conjugal life, it envisaged the final say for the husband, as well as the right to choose the couple's place of residence. Essentially, the new Civil Law slightly 'softened' the right of the husband, who was previously restricted, to command the wife, by providing in article 85 "A wife shall not subject to a husband's order, if he is using his right villainously." ${ }^{57}$ Namely, the first sentence of article 85 guarantees equality of spouses, the last one provides that a wife must obey a husband's orders, insofar these are not villainous. Professor Vasilijs Sinaiskis wrote in 1939 that "The Civil Law has abolished the husband's power (as it was envisaged in the old law) and introduced the principle of spouse's equality, since all members in an association are equal,"58 'cunningly' placing the parenthesis, since 'the husband's power' was not totally abolished. Women were elected as members to the People's Council and later to the Constitutional Assembly and were active in these bodies only because European social democracy had a strong women's movement, and at the moment of establishing the state social democrats were rather popular in Latvia, and also other forces founding the state were liberal or moderate conservatives. After the state was established and society stabilised, returning to more conservative values, the situation changed, and from then until the very occupation of Latvia in 1940 no women were elected to the legislator, except Berta Pipina, from the Democratic Centre, who was a member of the Saeima [Parliament] from 1931 to $1934 .{ }^{59}$

All in all, it could be considered that women's involvement in legislation, when the state of Latvia was established, was a miracle, just like the fact that Latvia was established. A woman, who has been brought up in patriarchal spirit, even if she is educated and freethinking, cannot be as politically active and able to speak in public and substantiate her views as a man. Patriarchal society is a society with division of labour between the genders: home and introversion are assigned to woman, but work outside home, the world or extraversion is the realm of man. A single, adult woman without a father, without a husband, who has to manage her property or earn her living, is an exception. Such a woman traditionally has certain selfdetermination also in a patriarchal society. ${ }^{60}$

Gender statuses are not only legally determined, they are determined by the public opinion and traditions. Public opinion is not easy to change, since it is, by its nature, stable and conservative, if it is allowed to develop evolutionary. However, this is not the case of the Latvian nation, since in 1940 the Soviet law was introduced, which, by using the coercive force of the state, embodied full rights of a woman and gender equality. ${ }^{61}$

57 1937. gada 28. janvāra Latvijas Republikas Civillikums [Civil Law of the Republic of Latvia of January 28, 1937]. Rīga: Kodifikācijas nodaḷa, 1938, p. 24.

58 Sinaiskis, V. Mūsu tiesības un pienākumi jaunajā Civīllikumā [Our rights and obligations in the new Civil Law]. Sējejjs, No. 1, 1938, p. 35.

59 The Members of 1, 2, 3 and 4 Saeima. Available: http://www.saeima.lv/lv/par-saeimu/likumdevejuvesture [last viewed 02.03.2019]; Kalniņš, A. Sievietes pirmās Latvijas brīvvalsts parlamentā [Women in the Parliament during the First Free State of Latvia]. Brìvā Latvija, No. 33, 1998, p. 4.

60 Even though not in every patriarchal society, because there are also other close men: paternal uncles, sons, brothers'-in-law, who can become guardians of a single, weak woman.

${ }^{61}$ Vēbers, J. Ģimenes tiesības [The Family law]. Rìga: Pētera Stučkas Latvijas Valsts universitātes Juridiskā un filozofijas fakultāte, 1970, p. 20. 


\section{Summary}

1. Gender inequalities persisted in European countries until the $20^{\text {th }}$ century; women did not have full political rights and they were restricted in their legal competence to act. The school of natural law laid the foundations for the idea of equality of all human beings, but socialists demanded emancipation of women, first of all, granting to them the right to vote and the right to submit a claim for divorce to court.

2. In Latvia, the foundations of gender equality were laid already at the time of establishing the state, providing for women's full political rights in "Political Platform of the Latvian People's Council". Women actively exercised the newly acquired right to vote and to be elected by participating in the first legislative institution - the People's Council and in the Constitutional Assembly.

3. Women's rights' activists, having acquired full political rights, fought for civil marriage and freedom to divorce, but a wife's equality in the family was the next aim. Gender equality in the Republic of Latvia marriage law was established with the law "On Marriage" of 1921; however, in the inter-war period further consolidation of gender equality did not take place here, since the society returned to conservative values and retained a model of the family 'with husband's restricted power'.

4. Society, even after women have been granted full political rights by law, is not in a hurry to change gender statuses and the model of the family. Public opinion evolves slowly. However, the state may impose new gender statuses and a model of the family, as it happened in Latvia after it was occupied by the Soviet Union. The Soviet law was the first in Europe to provide for full gender equality.

\section{Sources}

\section{Bibliography}

1. [Without author]. Latvijas Satversmes Sapulces locekles [Members of the Constitutional Assembly of Latvia]. Sieviete, No. 5, 1924, p. 126.

2. Aralovec, N. Gorodskaja semja v Rossiji, 1927-1959 gg. [The urban family in Russia, 1927-1959]. Tula: Grif i K, 2009.

3. Armitage, D. The Declaration of Independence: A Global History. Harvard: Harvard University Press, 2009.

4. Aspazija. Runa Satversmes sapulces 10. decembra sēdē [Speech at the meeting on December 10 of the Constitutional Assembly]. Sociāldemokräts, No. 285, 1920, p. 1.

5. Blūzma, V. Latvijas Republikas valsts dibināšana un nacionālās tiesību sistēmas veidošana (1918-1922) [Foundation of the Republic of Latvia and the creation of the National Legal System (1918-1922)]. In: Latvijas tiesību vēsture (1914-2000). A. Lēbers (ed.). Rìga: fonds "Latvijas Vēsture", 2000.

6. Bukovskis, V. Jaunā civilkodeksa izstrādāšanas darbība [The Development of the new Civil Code]. Tieslietu Ministrijas Vēstnesis, No. 1, 1921, pp. 32-40.

7. Dzilıleja, K. "Ģimenes galva" ["Head of the family"]. Sociäldemokräts, No. 76, 1929, p. 1.

8. Eljaševs, D. Sievietes zvērinātā advokatūrā [Women as attorneys]. Tieslietu Ministrijas Vēstnesis, No. 3, 1933, p. 52.

9. Fischer, I. Zur Problematik der Erfassung von Aktengut zu Gender- und Frauengeschichte im Archiv der sozialen Demokratie. Available: http://www.fes.de/archiv/adsd_neu/inhalt/recherche/ frauenbestand/text.htm [last viewed 26.02.2019].

10. Gouges, O. de. The Declaration of the Rights of Women (September 1791). Available: https://chnm. gmu.edu/revolution/d/293/ [last viewed 21.02.2019].

11. Horn, N. Einführung in die Rechtswissenschaft und Rechtsphilosophie. 4. Auflage. Heidelberg: C. F. Müller, 2007. 
12. Jarvelaids, $P$. Baltijas civiltiesību "tēvs" Frīdrihs Georgs fon Bunge [Baltic Civil Law "father" Friedrich Georg von Bunge]. Jurista Vārds, No. 44/45(846/847). Available: http://www.juristavards. lv/doc/199956-baltijas-civiltiesibu-tevs-fridrihs-georgs-fon-bunge/ [last viewed 21.02.2019].

13. Kalniņšs, A. Sievietes pirmās Latvijas brīvvalsts parlamentā [Women in the Parliament during the First Free State of Latvia]. Brīvā Latvija, No. 33, 1998, p. 4.

14. König, R. Familiensoziologie. Berlin, Heidelberg: Springer-Verlag, 2013.

15. Korppi, A. A Long Tradition of Equality: Women's Suffrage in Finland. In: The Straggle for Female Suffrage in Europe: Voting to Become Citizens. B. Rodriguez-Ruiz, R. Rubio-Marin (eds.). LeidenBoston: Brill, 2012.

16. Lazdiňš, J. Baltijas zemnieku privāttiesības (XIX gs.) [Civile law of the Baltic peasants (XIX century)]. Rīga: Biznesa augstskola "Turība”, 2000.

17. Lipša, I., Neiburgs, U. Nezināmā Aspazija. Remdeni? Nekad! [Unknown Aspasia. Moderately? Never!]. TVNet, 14.03.2005. Available: https://www.tvnet.lv/6178263/nezinama-aspazija-remdeninekad [last viewed 27.02.2019].

18. Marx, K., Engels, Fr. Das Manifest der Kommunistische Partei. Zittau: Berndt Müller Verlag, 2009.

19. Mironov, B. Socialnaja istorija Rossiji perioda imperiji (XVIII - nachalo XX vv.): genezis lichnosti, demokraticheskoj semji, grazhdanskogo obshchestva i pravovogo gosudarstva [The social history of Russia during the empire (XVIII - early XX centuries): the genesis of the individual, the democratic family, civil society and the rule of law]. Sankt-Peterburg: izdatelstvo Dm. Bulanin, 1999, Vol. 1.

20. Mousset, S. Women's Rights and the French Revolution: A Biography of Olympe De Gouges. New Brunsvick, London: Transaction Publishers, 2007.

21. Rommelanger, U. Das konsultative Referendum. Berlin: Duncker \& Humbolt, 1988.

22. Schlosser, H. Grundzüge der Neueren Privatrechtsgeschichte. Rechtsentwicklung im europäischen kontext. 10. Auflage. Heidelberg: C. F. Müller, 2005.

23. Sinaiskis, V. Civillikuma principi un gimenes tiesỉbas [Principles of civil law and family law]. Tieslietu Ministrijas Vēstnesis, No. 1, 1938, p. 45.

24. Sinaiskis, V. Mūsu tiesības un pienākumi jaunajā Civīllikumā [Our rights and obligations in the new Civil Law]. Sējējs, No. 1, 1938, pp. 34-40.

25. Stikāne, V. Sieviete Livonijas sabiedrībā viduslaikos un jauno laiku sākumā 13.-16. gs. [Woman in Livonian Society in the Middle Ages and Early Modern Times 13-16 Century]. Riga: Latvijas Universitāte, 2012.

26. Švarcs, F. Latvijas 1937. gada 28. janvāra Civillikums un tā rašanās vēsture [Latvian 28 January 1937 Civil Code and its drafting history]. Rīga: Tiesu namu aǵentūra, 2011.

27. Vēbers, J. Ģimenes tiesības [The Family law]. Rīga: Pētera Stučkas Latvijas Valsts universitātes Juridiskā un filozofijas fakultāte, 1970.

28. Vēbers, J. Gịimenes tiesības Latvijā. No neatkarīgas Latvijas valsts nodibināšanas 1918. gadā līdz neatkarības atjaunošanai 1991. gadā [Family law in Latvia. From the creation of an independent Latvian state in 1918 to the restoration of independence in 1991]. In: Latvijas Republikas Civillikuma komentāri. G̦imenes tiesības. Rīga: Mans Īpašums, 2000.

\section{Normative Acts}

1. 1918. gada 17. novembra "Latvijas Tautas Padomes politiskā platforma" ["Political Platform of the Latvian National Council” of November 17, 1918]. In: Latvijas Tautas Padomes sēdes. Vol. 1. Rīga: Satversmes Sapulce, 1920, pp. 6-7.

2. 1919. gada 19. augusta Latvijas Tautas Padomes "Latvijas Satversmes sapulces vēlēšanu likums" [The law on elections to the Constitutional Assembly of Latvia of August 19, 1919]. In: Latvijas Pagaidu Valdības Likumu un Rīkojumu krājums. Rīga: Valsts kanceleja, 1919, p. 124.

3. 1937. gada 28. janvāra Latvijas Republikas Civillikums [Civil Law of the Republic of Latvia of January 28, 1937]. Rīga: Kodifikācijas nodaḷa, 1938.

4. Latvijas Republikas Satversmes Sapulces 1921. gada 1. februāra "Likums par laulību” [Marriage Law, adopted by the Constitutional Assembly of the Republic of Latvia on 1 February 1921]. In: Tieslietu Ministrijas Vēstnesis, No. 1/3, 1921, pp. 65-74.

5. Latvijas Republikas Satversmes Sapulces 1921. gada 18. februāra "Likums par civilstāvokḷa aktu registrāciju [The Law on Registration of Civil Status Acts, adopted by the Constitutional Assembly of the Republic of Latvia on 18 February 1921]. Tieslietu Ministrijas Vēstnesis, No. 1/3, 1921, pp. 75-82.

6. Svod grazhdanskih uzakonenij gubernij Pribaltijskih (Chastj III Svoda mestnih uzakonenij gubernij Ostzejskih) [The Code of Civil Laws of the Baltic Provinces (Part III of the Code of Local Laws of the Ostsee provinces)]. Petrograd: Pravo, 1915. 


\section{Draft Laws and Other Sources}

1. Likumprojekts par saderināšanos, laulāto ḷaǔ̌u personīgām un mantiskām attiecībām un vinuu mantošanu [On Engagement, Personal and Property Relations of Married People and Inheriting Thereof]. Tieslietu Ministrijas Vēstnesis, No. 3, 1924, pp. 101-116.

2. The Members of 1,2,3 and 4 Saeima. Available: http://www.saeima.lv/lv/par-saeimu/likumdevejuvesture [last viewed 02.03.2019].

3. Deputātu personu rādītājs [List of Deputies]. In: Latvijas Satversmes sapulces stenogrammu rādìtājs. H. Kärkliņ̌̌ (ed.). Rìga: Latvijas Republikas Saeima, 1925.

4. Latvijas Satversmes Sapulces deputātu saraksts [List of deputies of the Constitutional Assembly of Latvia]. In: Latvijas Satversmes Sapulces stenogrammu izvilkums (1920-1922). Rīga: Tiesu namu ag̀entūra.

5. Aspazija. Starpsaucieni Jāṇa Purgaḷa runai vispārējās debatēs par Satversmes I daḷu IV sesijas 5. sēdē 1921. gada 28. septembrī [Interjection to Jānis Purgalis Speech in General Debate on Part I of the Satversme at the $4^{\text {th }}$ Session of the $5^{\text {th }}$ meeting on 28 September 1921]. In: Latvijas Satversmes sapulces stenogrammu izvilkums (1920-1922). Rìga: Tiesu namu aǵentūra, 2006, p. 130. 


\title{
Content and Application of Duty of Care Principle in the Field of Administrative Law in Latvia
}

\author{
Dr. iur. Jautrīte Briede \\ Faculty of Law, University of Latvia \\ Professor at the Department of Public Law \\ E-mail: briede@/u.Iv
}

\begin{abstract}
The article addresses the principle of duty of care, which is identified as one of the principles of the European Union's administrative process. First of all, the use of term 'duty of care' in Latvian language is analysed and shortcomings identified. The content of the duty of care principle in relation to the principle of good administration and the non-contractual liability of the state is further clarified. The article also touches upon the question of the immunity of the authorities to liability for non-compliance with the duty of care.
\end{abstract}

Keywords: principle of duty of care, duty of care to civil servants, principle of good administration, negligence or omission of public authorities, non-contractual liability of the state, immunity of public authorities.

\section{Contents}

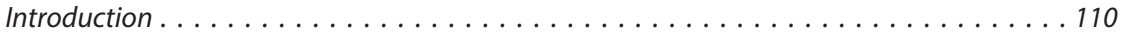

1. Terms Used in Latvian Language . . . . . . . . . . . . . . . . . . . . . . 111

2 Duty of Care Principle and Principle of Good Administration . . . . . . . . . . . . 112

3. Duty of Care Principle and Non-contractual Liability of Public Authorities . . . . . . . . 115

Summary . . . . . . . . . . . . . . . . . . . . . . . . . . . . . . . . . . 119

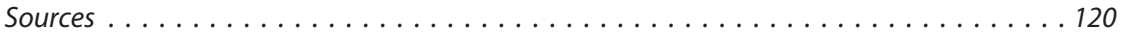

Bibliography ............................... 120

Normative Acts ............................... 120

Recommendations ............................ 120

Case Law . . . . . . . . . . . . . . . . . . . . . . . . . . . 120

Other Sources . . . . . . . . . . . . . . . . . . . . . . . . . . . . . 121

\section{Introduction}

The analysis of the principles pertaining to the European Union's administrative process by professors from several European countries (made by request of the Committee on Legal Affairs of the European Parliament) contains the following list of basic principles: Access to information and access to documents; Access to the file; Duty of care; Data protection; Data quality; Effective remedy; Equal treatment and non-discrimination; Fair hearing; Fairness; Good administration; Impartiality; 
Legal certainty; Legality; Legitimate expectations; Participatory democracy; Proportionality; Reason giving; Rule of Law; Timeliness; Transparency. ${ }^{1}$

If the majority of these principles have been analysed by Latvian legal scholars ${ }^{2}$ and are used in judicial practice, the content of the duty of care principle (in Latvian - rūpìbas pienākuma princips, in French - devoir de vigilance or obligation de diligance $e^{3}$ ) from the point of view of administrative law has not yet been addressed.

The aim of this study is to clarify the content of the duty of care principle and to offer recommendations for its application in the area of administrative law in Latvia.

The study is based on content analysis to establish how the principle is applied and reflected in court judgments. The linguistic method has also been used to determine the words used when applying it. The comparative method is applied to reflect how the principle is used in other countries. The case study method helps to clarify the application of the principle in court practice.

The article does not address the duty of care of individuals against public administration or other private individuals.

\section{Terms Used in Latvian Language}

To define the content of the principle, the Latvian translation of the term 'duty of care' must first be provided. In the Latvian Academic Terminology Database AkadTerm, the term 'duty of care' is recommended to be translated as rüpibas pienākumu or gādìbas pienākumu, however, the term pienākums n,emt vērā ierēdnu intereses [duty to have regards to the interests of civil servants] is also mentioned. ${ }^{4}$

However, the term pienākums n,emt vērā ierēdnu intereses [duty to have regards to the interests of civil servants] does not always correspond to the English 'duty of care'. Before the author of this article raised the issue of translation, the term had also been misused in translations contained in the database of EU courts. For example, the Advocate General's Opinion in case No. C-184/16 addresses the issue of the application of the principle of good administration in relation to a residence of a national of a member state within the territory of another member state. This case has nothing to do with the interests of civil servants, yet the phrase 'the referring court was enquiring about the relevance of the duty of care" literally was translated as "the referring court was enquiring about the relevance of the 'duty to have regards to the interests of civil servants' [pienākums n,emt vèrā ierēdn,u intereses

1 The General Principles of EU Administrative Procedural Law. In-depth Analysis. European Parlament. Directorate General for Internal Policies, Policy Department C: Citizens' Rights and Constitutional Affairs. The Committee on Legal Affairs, 2015. Available: http:// www.europarl.europa.eu/RegData/etudes/IDAN/2015/519224/IPOL_IDA\%282015\%29519224_ EN.pdf [last viewed 17.10.2018].

2 See, for example, the comments on the principles in the book Administrativā procesa likuma komentāri. A un B dạ̦a [Comments upon Administrative Procedure Law. Parts A and B]. Collective of authors, scientific ed. Dr. iur. J. Briede. Rīga: Tiesu namu aǵentūra, 2013.

3 The conclusion on the substitutability of these terms is made by comparing the text of the European Court of Justice in different languages. Obligation de diligance in English sometimes is translated as 'duty of care', but sometimes as 'principle of due diligence' or 'duty to act diligently'.

4 LZA Terminologijas komisijas akadēmiskā terminu datubāze AkadTerm [Latvian Academy of Sciences academic terminology database AkadTerm]. Available: http://termini.lza.lv/term. php?term=duty\%20of\%20care\&lang=EN [last viewed 17.10.2018]. 
atbilstìbu]". ${ }^{5}$ It is clear from the context of the case that it is a duty of care and not a duty of care to civil servants.

Similarly, the interests of civil servants were wrongly pointed out in Latvian translation of the Opinion of Advocate General in case No. C-684/16, paragraph 40, although the case is clearly not about civil servants but about workers on a contract of employment. ${ }^{6}$ The term in the electronic version of the database was changed accordingly after the author of this article addressed the issue to interpreters of the European Court of Justice.

Although there are cases, in which 'duty to have regards to the interests of civil servants' does not cause confusion, because the case deals with civil servants, it would be enough to mention the duty of or care without the emphasis on civil servants. ${ }^{7}$

Probably the aforementioned term is used because of the fact that the English term 'duty of care', at least within the framework of the European Union courts, initially is attributed to civil servants. ${ }^{8}$ Nevertheless, it has been mentioned recently in the context of good governance. It is also possible that the duty of care is rooted in the field of private law, namely, labour law. In several countries, it is recognized that the employer under the duty of care in general must take care of the welfare of its employees. ${ }^{9}$

In view of the above arguments, in Latvian language it would be advisable not to use the term pienäkums n,emt vērā ierēdnu intereses [duty to have regards to the interests of civil servant], but only the term rüpibas (gādìbas) pienākums [duty of care]. The term pienācìgas rūpibas princips [principle of due diligence], found in the European Union database may also be used. ${ }^{10}$

\section{Duty of Care Principle and Principle of Good Administration}

As indicated in the analysis mentioned in the introduction, the duty of care includes the right of every person to have his or her affairs handled impartially, fairly and within a reasonable time. The authors of the document refer to the first paragraph, article 41 of the Charter of Fundamental Rights of the European Union, which provides that every person has the right to have his or her affairs handled impartially, fairly and within a reasonable time by the institutions, bodies, offices and agencies of the Union. ${ }^{11}$ The analysis explains that the principle obliges the administration to carefully establish and review all the relevant factual and legal

5 The Court of Justice of the European Union case No. C-184/16, opinion of Advocate-General M. Szpunar, para. 72. Available: www.curia.europa.eu [last viewed 17.10.2018].

6 The Court of Justice of the European Union case No. C-684/16, opinion of Advocate-General Y. Bot, para. 40. Available: www.curia.europa.eu [last viewed 17.10.2018].

7 See, for example, Judgment of the Court of Justice of the European Union in case No. C-220/13 P, para. 25 and 69, case No. C-496/08 P, paras. 28 and 60. Available: www.curia.europa.eu [last viewed 17.10.2018].

8 See database of European Union courts. Available: www.curia.europa.eu [last viewed 17.10.2018].

9 See, for example, Opinion of Advocate General Bot delivered on 29 May 2018 in case No. C-684/16 (para. 40) and C-619/16 (para. 42) of the European Court of Justice. Available: www.curia.europa. eu [last viewed 17.10.2018]; Cossart, S., Chaplier, J., Beau de Loménie, T. The French Law on Duty of Care: A Historic Step Towards Making Globalization Work for All. Business and Human Rights Journal, Vol. 2, Issue 2, July 2017, pp. 317-323.

10 See, for example, application to the Court of Justice of the European Union, case No. T-778/16. Available: www.curia.europa.eu [last viewed 17.10.2018].

11 Charter of Fundamental Rights of the European Union. (2016/C 202/02). Available: https://eur-lex. europa.eu/legal-content/LV/TXT/?uri=CELEX\%3A12012P\%2FTXT [last viewed 17.10.2018]. 
elements of a case taking into account not only the administration's interests but also all other relevant interests, prior to making decisions or taking other steps. ${ }^{12}$ Impartiality requires the absence both of arbitrary action and of unjustified preferential treatment including personal interest. ${ }^{13}$

The duty of care is not always directed towards the protection of individual rights, but it can also be the opposite of an individual's interests. For example, the Court of Justice of European Union has indicated: "Member States are to make a full and timely attempt to recover the sums in question by having recourse to all available means to achieve the objective of protecting the financial interests of the European Union. Otherwise, a Member State must be considered to have breached its general obligation of diligence." 14

The authors of the aforementioned analysis note: when the Court of Justice relates to a general principle of EU law, it uses very few words, and it is not always clear whether they are interchangeable. Typically, many of the rulings quoted in the Explanations to article 41 of the Charter refer to the 'principle of good administration' and to the 'duty of care' in the same sentence. ${ }^{15}$

The Court of Justice also stated that the duty of care is one of the elements of good governance. So, the Court has pointed out, it must also be borne in mind that the duty to act diligently, which is inherent in the principle of sound administration and applies generally to the actions of the EU administration in its relations with the public, requires that that administration act with care and caution. ${ }^{16}$

The title of article 41 of the Charter of Fundamental Rights of the European Union, to which the authors of the analysis refer, is the Right to Good Administration. The second paragraph of the article states that this right includes the right of every person to be heard, before any individual measure which would affect him or her adversely is taken, the right of every person to have access to his or her file, while respecting the legitimate interests of confidentiality and of professional and business secrecy, and the obligation of the administration to give reasons for its decisions.

Regarding the third part of the article, every person has the right to have the Union make good any damage caused by its institutions or by its servants in the performance of their duties, in accordance with the general principles common to the laws of the member states.

The principle of good administration as one of the principles of state administration is mentioned also in the fifth paragraph of article 10, State Administration Structure Law ${ }^{17}$ of Latvia. It explicates that the principle includes

12 The authors refer to cases: AG van Gerven in case No. C-16/90, Eugen Nölle v. Hauptzollamt Bremen - Freihafen [1991] ECR I-5163; case No. C-269/90 TU München v. Hauptzollamt München Mitte [1991] ECR I-5469, para. 14.

13 The General Principles of EU Administrative Procedural Law. In-depth Analysis. European Parlament. Directorate General for Internal Policies, Policy Department C: Citizens' Rights and Constitutional Affairs. The Committee on Legal Affairs, 2015, p. 19.

14 The Court of Justice of the European Union case No. C-587/17P, opinion of Advocate-General N. Wahl, para. 94.

15 The General Principles of EU Administrative Procedural Law. In-depth Analysis. European Parlament. Directorate General for Internal Policies, Policy Department C: Citizens' Rights and Constitutional Affairs. The Committee on Legal Affairs, 2015, p. 12.

16 The Court of Justice of the European Union judgment of 4 April 2017 in case No. C-337/15P, para. 34.

17 State Administration Structure Law is the official title of the Law. I would call it the Law on Public Administration. 
openness to individuals and society, data protection, the implementation of fair procedures within a reasonable time and other provisions aimed at ensuring that public authorities respect the rights and legal interests of individuals. ${ }^{18}$ Pursuant to article 11, paragraph two of this law, if the principle is not conformed to, the private individual whose rights and lawful interests are affected is entitled to require the compliance therewith in accordance with the procedures of administrative procedure. As it appears, the framework of the principle of good governance, which legislators of the European Union and Latvia seek to explain, is very broad and includes several sub-principles.

It follows from the judgments of the Court of Justice of the European Union and from the opinions of Advocates General that the duty of diligence is most often associated with the stage of factual (objective) investigation. An example is a case where the Court answered questions referred by the Supreme Court of Latvia, the Court of Justice adverted, that in view of the obligation imposed upon the customs authorities to exercise due care, the authorities are required to consult all the information sources and databases available to them, it is also appropriate to allow the person concerned to provide them with any information. ${ }^{19}$ In another case, the Court has examined whether the Commission exercised due care, exhaustively investigated other potential analogue countries and took account of other publicly available statistical information to guide its choice ${ }^{20}$ to establish whether the information contained in the file in the case was considered with all the care required thereof. ${ }^{21}$

It can be concluded that the content of the principle of duty of care thus fulfilled in essence corresponds to the principle of observance of the rights of a private person enshrined in article 5 of the Latvian Administrative Procedure Law ${ }^{22}$ (providing that the public authority and the court shall, within the framework of the applicable legal provisions, promote the protection of the rights and legal interests of the individual), and the principle of procedural fairness enshrined in article $14^{1}$ (providing that the public authority and the court, when taking decisions, respect the impartiality and give the participants of the proceedings an adequate opportunity to express their views and submit evidence; an official whose objectivity may have reasonable doubts shall not participate in the decision). The principle of prohibition of arbitrariness is also worth mentioning. It is enshrined in article 9 of the Law, according to which a decision may be based on the facts necessary for its adoption and on objective and rational legal considerations arising therefrom.

Recommendation of Council of Europe on good administration, ${ }^{23}$ which summarizes the basic principles of public administration of the member states of Council of Europe, implies nine principles of good administration, but the principle of duty of care or due diligence is not explicitly identified in the text. The most

18 Valsts pārvaldes iekārtas likums [State Administration Structure Law]. Adopted 06.06.2002. Available: https://likumi.lv/doc.php?id=63545 [last viewed 20.06.2019].

19 The Court of Justice of the European Union judgment of 9 November 2017 in case No. C-46/16, para. 54-56.

20 The Court of Justice of the European Union judgment of 10 September 2015 in case No. C-687/13, para. 46.

21 Paragraph 51 of the judgment.

22 Administratīivā procesa likums [Administrative Procedure Law]. Available: https://likumi.lv/ta/ $\mathrm{id} / 55567$-administrativa-procesa-likums [last viewed 20.06.2019].

23 Recommendation $\mathrm{CM} / \operatorname{Rec}(2007) 7$ of the Committee of Ministers to Member States on good administration. (Adopted by the Committee of Ministers on 20 June 2007 at the 999bis meeting of the Ministers' Deputies). Available: https://rm.coe.int/16807096b9 [last viewed 14.01.2019]. 
appropriate of the listed principles could be the principle of impartiality, under which public authorities shall act objectively, having regard to relevant matters only. They shall not act in a biased manner and they shall ensure that their public officials carry out their duties in an impartial manner, irrespective of their personal beliefs and interests. ${ }^{24}$

Considering the fact that principle of duty of care in the European Union court rulings is used as a synonym for principle of good administration or for the principles deriving therefrom, and considering that in Latvia the principles of good administration and good administrative procedure are enshrined in legislation and already applied in the practice of public authorities and administrative courts, there is no need for special emphasis on the principle of duty of care in Latvia with regard to good governance. It is also not advisable to replace the principle of good administration with the duty of care principle.

\section{Duty of Care Principle and Non-contractual Liability of Public Authorities}

Examining the application of the duty of care principle in the case law of the European Court of Human Rights and case law of other countries, it can be inferred that the principle is often applied in dealing with the issue of non-contractual liability of the state, namely, liability for omission or negligence of the public authority.

In this sense, the principle is used in the Anglo-Saxon legal system, where the principle of duty of care is a general principle of law, which is applied in both private and public law. ${ }^{25}$ However, the application of this principle to private and public law differs. In the area of public law, this principle is applied to the obligation of public authorities to exercise its powers properly or to fulfil its obligations. The principle is applied in cases of alleged liability for failure to take preventative action in particular, the failure of public authorities to exercise their legislatively based powers to regulate or to control human activity, or to attempt to do so. ${ }^{26}$ However, the common law has also recognised special factors applicable to statutory and other public authorities, which may render negative a duty of care that a private individual would owe in apparently similar circumstances, or result in the standard of care owed to a plaintiff by a statutory authority being less than that which would be owed by a private party. ${ }^{27}$

The US Supreme Court stated: when statutory powers are conferred, they must be exercised with reasonable care - so that if the relevant function is performed negligently, a cause of action may arise (for example, taking measures to prevent the spread of virus from a private mollusc farm). Duty of care does not exist, inter alia, for the following reasons : 1) imposing a duty would result in conflicting duties owed by the state to the groups of society with opposite interests; 2) the potential indeterminacy of the class of people the state owes the alleged duty to; 3) the state

24 Article 4 of the Recommendation.

25 Campbell, J., Roucek, N. An Introduction to the Civil Liability of Public Authorities - State Legal Conference. NSWJSchol, 13, 2014, p. 2. Available: http://classic.austlii.edu.au/au/journals/ NSWJSchol/2014/13.pdf [last viewed 14.01.2019].

26 See, for example, The Duty of Care of Public Authorities. Available: https://www.researchgate.net/ publication/314732215_The_Duty_of_Care_of_Public_Authorities [last viewed 20.01.2019].

27 Campbell, S., Roucek, N. An Introduction to the Civil Liability of Public Authorities. Available: http://classic.austlii.edu.au/au/journals/NSWJSchol/2014/13.pdf [last viewed 08.10.2018]. 
did not have sufficient degree of control which justifies the imposition of a duty of care; 4) the plaintiff's claim of vulnerability is not a sufficient; 5) the potential liability of the state is disproportionate to any fault that might be attributed to it, in preferring the interests of one group over another, when deciding whether or not to exercise one of the relevant statutory powers; 6) the state's powers in question are quasi-legislative nature. ${ }^{28}$

In UK, in order to show a duty of care, the claimant must satisfy a threefold test, establishing: 1) that damage to the claimant was foreseeable; 2) that the claimant was in an appropriate relationship of proximity to the defendant; 3 ) that it is fair, just and reasonable to impose liability on the defendant. These criteria apply to claims against private persons as well as claims against public bodies. ${ }^{29}$

The UK courts, when deciding whether a duty of care has been respected, verifies whether the person in question was entitled to expect specific duties from the state. For example, there is a conclusion, if a maniac is to be caught, the police have a wide discretion to plan their tactics, but no one has the right to expect his or her special protection. There is no general duty of care owed to individual members of the public by the responsible authorities to prevent the escape of a known criminal or to recapture him. Similarly, the duty of care has not been infringed if police forces have failed to catch some criminal as soon as they might have done, with the result that he went on to commit further crimes. ${ }^{30}$ In such cases, state liability does not arise and the public authorities' immunity institution is applied.

English judges only recognize a breach of duty of care if a person was in an appropriate relationship of proximity likely to expose him or her to a special risk of damage from the criminal acts of others, greater than the general risk, which ordinary members of the public must endure with phlegmatic fortitude. An example is a case where the plaintiff had passed on information in confidence to the police about the identity of a person implicated in the killing of a police officer, expressing her concern that she did not want the source of the information to be traced back to her. The information was recorded, naming the plaintiff, in a document subsequently left in an unattended police vehicle, which was broken into, and the document was stolen, coming into possession of the person implicated, and the plaintiff was threatened with violence and arson, and suffered psychiatric damage. When deciding on the state's liability, the court found that the police had a duty of care towards the plaintiff, since disclosure of the information could create and, in that particular case, created a special risk (hazard) for her. Moreover, the fight against crime is daily dependent upon information fed to the police by members of the public, often at real risk of villainous retribution from the criminals

28 Revisiting the imposition of a duty of care on public authorities: Regent Holdings. Available: http:// www.nortonrosefulbright.com/knowledge/publications/116719/revisiting-the-imposition-of-aduty-of-care-on-public-authorities-regent-holdings [last viewed 08.10.2018].

29 See Judgement of the European Court of Human Rights judgment of 10 May 2001 in case T. P. and K. M. v. the United Kingdom, No. 28945/95, para. 46. Available: https://hudoc.echr.coe.int [last viewed 14.01.2019].

30 Hill v. Chief Constable of West Yorkshire ([1989] Appeal cases at p. 53). Quoted by the judgments the European Court of Human Rights delivered on 28 October 1998 in case Osman v. United Kingdom (Application No. 23452/94). See para. 90-91. Available: https://hudoc.echr.coe.int [last viewed 14.01.2019]. 
and their associates. ${ }^{31}$ In another case, the court found liability in negligence where the police had taken a man into custody, knew he was a suicide risk but did not communicate that information to the prison authorities. The man, diagnosed as suffering from clinical depression had committed suicide in remand prison. The police, which had assumed responsibility for the man, had owed a duty of care, which they had breached with the result that his death had ensued. ${ }^{32}$

Similarly, in Australia infringement of the duty of care principle is associated with responsibility for negligence of public institutions. The legal institution of immunity of public authorities is applied in Australia and the United Kingdom alike. This is particularly the case for police actions and omissions, but also for other institutions. For example, child protection authorities owe no duty to parents suspected of child abuse, parole board is held to owe no duty of care to someone injured by parolee.

For liability for breach of duty of care, 6 criteria must be met: 1) Reasonable foreseeability (Would a reasonable public authority reasonably foresee that its act or omission, including a failure to exercise its statutory powers, might result in injury to the plaintiff or his or her interests?); 2) Control (Was the authority in a position of control and did it have the power to control the situation that brought about the harm to the injured person?); 3) Vulnerability (Was the injured person or his or her interests vulnerable in the sense that the injured person could not reasonably be expected to adequately safeguard himself or herself or those interests from harm?; 4) Risk to specific class, not public generally (Did the public authority know, or ought it to have known, of an existing risk of harm to the plaintiff or, in some cases, to a specific class of persons who included the plaintiff (rather than a risk to the general public?); 5) Not legislative or quasi-legislative (Would the imposition of the duty of care impose liability with respect to the defendant's exercise of 'core policy-making' or 'quasi-legislative' functions?); 6) No overriding policy (Was there any supervening policy reason that denies the existence of a duty of care?). A public authority is under no duty of care in relation to decisions involving or dictated by financial, economic, social or political factors or constraints. ${ }^{33}$

The European Court of Human Rights has also applied the principle of duty of care in its rulings when deciding on the state's responsibility for human rights violations. For example, in the case Jasinskis v. Latvia (the applicant' son, who had been deaf and mute since birth, had died after being taken into police custody), the Court pointed out that persons in custody are in a vulnerable position and the authorities are under a duty to protect them. Where the authorities decide to place and maintain in detention a person with disabilities, they should demonstrate special care in guaranteeing such conditions as correspond to his special needs resulting from his disability. ${ }^{34}$

31 Swinney and another $v$. the Chief Constable of Northumbria ([1997] Queen's Bench Reports at p. 464). Quoted by the judgments the European Court of Human Rights delivered on 28 October 1998 in case Osman v. United Kingdom (Application No. 23452/94). See para. 93-94. Available: https://hudoc.echr.coe.int [last viewed 14.01.2019].

32 Kirkham v. the Chief Constable of Manchester. Quoted by the judgments the European Court of Human Rights delivered on 28 October 1998 in case Osman v. United Kingdom (Application No. 23452/94). See para. 95. Available: https://hudoc.echr.coe.int [last viewed 14.01.2019].

33 Lunz, H. The Duty of Care of Public Authorities. Presentation. January 2006. Available: https://www.researchgate.net/publication/314732215_The_Duty_of_Care_of_Public_Authorities [last viewed 14.01.2019].

34 The European Court of Human Rights judgment of 21 December 2010 in case Jasinskis v. Latvia, para. 59. Latvijas Vēstnesis, No. 196(4594), 14.12.2011. 
The European Court of Human Rights has also stated, that bearing in mind the difficulties involved in policing modern societies, the unpredictability of human conduct and the operational choices which must be made in terms of priorities and resources, such an obligation must be interpreted in a way which does not impose an impossible or disproportionate burden on the authorities. Accordingly, not every claimed risk to life can entail for the authorities a Convention requirement to take operational measures to prevent that risk from materialising. In the opinion of the Court, where an allegation exists that the authorities have violated their positive obligation to protect the right to life in the context of their aforementioned duty to prevent and suppress offences against the person, it must be established to its satisfaction that the authorities knew or ought to have known at the time of the existence of a real and immediate risk to the life of an identified individual or individuals from the criminal acts of a third party, and that they failed to take measures within the scope of their powers which, judged reasonably, might have been expected to avoid that risk. ${ }^{35}$

The Latvian legal norms, in essence, provide for the liability of the state administration for the violation of the duty of care. Namely, regarding the first paragraph of the article 4 of the Law on Compensation for Damage Caused by Public Administration ${ }^{36}$ public authority may also cause the loss through inaction, if the authority had a duty to act, but it did not act unlawfully. Article 10 of the law also provides for the co-responsibility of the victim, that is, the amount of the compensation decreases, or it cannot be received at all if the victim has not tried to eliminate the loss or has contributed to the loss.

Although the Latvian administrative courts, when deciding on compensation for failure or improper performance of the obligations of public authorities, have not indicated a duty of care directly in the text, in several judgments the courts have actually analysed this duty. In particular, this applies to cases in which the applicants are persons in custody (prisoners). For example, in the case where the applicant complained about the prison administration about the fact that he has not been granted a personal care product (toilet paper and toothpaste) for a long time, the court pointed out that the prisoner is vulnerable, he or she is under the absolute control and hence under protection of the state, that is why the state must provide conditions that respect human dignity. ${ }^{37}$ In essence, the court found that the public authority was obliged to take care of the prisoner but it did not fulfil that duty.

The administrative courts also dealt with the issue of the liability of the national medical authorities that failed to inform the person that hepatitis $\mathrm{C}$ virus had been detected in his blood. The court rejected the authority's argument that the absence of a diagnosis of the disease is a reason not to inform the person. The court pointed out that, in the event of infection, the obligation to provide information should be fulfilled as early as possible. ${ }^{38}$ In this judgment too, the court actually found that

35 The European Court of Human Rights judgment of 28 October 1998 in case Osman v. United Kingdom (No. (87/1997/871/1083), para. 116. Available: https://hudoc.echr.coe.int [last viewed 14.01.2019].

36 Valsts pārvaldes iestāžu nodarīto zaudējumu atlīizināšanas likums [Law on Compensation for Losses Caused by State Administration]. Available: https://likumi.lv/ta/id/110746-valsts-parvaldesiestazu-nodarito-zaudejumu-atlidzinasanas-likums [last viewed 20.06.2019].

37 Republic of Latvia Supreme Court judgment of 20 April 2012 in case No. SKA-372/12, para. 13. Available: www.at.gov.lv [last viewed 14.01.2019].

38 Republic of Latvia Supreme Court judgment of 26 June 2008 in case No. SKA-155/08, para. 30. Available: www.at.gov.lv [last viewed 14.01.2019]. 
there was a duty of care - the authorities had an obligation to inform the person about the detected virus.

Admittedly, the fact that the term 'duty of care' is not used in rulings of Latvian courts has no effect on the quality of judicial decisions. However, it could, in principle, be applied to create a separate category of cases with specific test criteria.

In the cases of such categories, the legal institution of institutional immunity discussed above should also be introduced (possibly finding a more appropriate Latvian term ${ }^{39}$ ). It should be noted that the findings that a public authority cannot take responsibility if it takes action within the framework of the duty of care could be found in the decisions of the Latvian courts. For example, there is a case in which the court rejected the claim against the Orphan's and Custody Court for interference in the applicant's private life, stating that the Orphan's and Custody Court is obliged to objectively and completely establish the circumstances of the parent's ability to take care of the child. ${ }^{40}$

The legal institution of immunity can also be found in legal norms of Latvia. For example, the article 22 of the law "On Police"4l provides that a police officer shall not be liable for economic and physical harm done, within the scope of authority of the service, to a person violating the law who does not submit or resists at the moment of arrest. It should be mentioned here that in such a case, the immunity of the state (a police) should only exist if the police obviously do not violate the principle of proportionality.

\section{Summary}

1. It would be advisable in Latvian language not to use the term pienākums nemt vêrā ierēdñu intereses [duty to have regards to the interests of civil servant], but only the term rūpìbas (gādìbas) pienākums [duty of care]. The term pienācīgas rüpïbas princips [principle of due diligence] which is found in the European Union database may also be used.

2. Considering that the duty of care principle in the European Union court rulings is used as a synonym for the principle of good administration or for the principles deriving therefrom, and considering that in Latvia principles of good administration and good administrative procedure are enshrined in legislation and are already applied in the practice of public authorities and administrative courts, with regard to good governance there is no need for special emphasis on the duty of care principle in Latvia. It is also not advisable to replace the principle of good administration with the duty of care principle.

3. When deciding on the state's liability for omission or negligence, the duty of care principle, which is widely used in the Anglo-Saxon legal system, is also applied in Latvia in substance. The use of the term 'duty of care' in cases of

39 In principle, the term 'immunity' is used in the legal language, see, for example likums "Par Lìgumu par Protokola par Eiropas Kopienu privilēgijām un imunitātēm izpildīšanu Latvijas Republikä" [Republic of Latva law "Agreement Implementing the Protocol on the Privileges and Immunities of the European Communities in the Republic of Latvia]. Available: https://likumi. lv/ta/id/88809-par-ligumu-par-protokola-par-eiropas-kopienu-privilegijam-un-imunitatemizpildisanu-latvijas-republika [last viewed 20.06.2019].

40 Administrative case No. A420697010. Unpublished.

${ }^{41}$ Likums "Par policiju” [Republic of Latvia law “On Police"]. Available: https://likumi.lv/ta/id/67957par-policiju [last viewed 20.06.2019]. 
this category would facilitate the establishment of specific test criteria for such cases.

4. For cases on the state's liability for omission or negligence, the legal institute of institutional immunity should be established.

\section{Sources}

\section{Bibliography}

1. Administratīvā procesa likuma komentāri. A un B daḷa [Comments upon Administrative Procedure Law. Parts A and B]. Collective of authors, scientific ed. Dr. iur. J. Briede. Rīga: Tiesu namu aǵentūra, 2013.

2. All Answers ltd, 'Development of the principles of tort law'. January 2019. Available: https://www. lawteacher.net/free-law-essays/contract-law/development-of-the-principles-of-tort-law-contractlaw-essay.php?vref=1 [last viewed 19.01.2019].

3. Campbell, J., Roucek, N. An Introduction to the Civil Liability of Public Authorities - State Legal Conference. NSWJSchol, 13, 2014. Available: http://classic.austlii.edu.au/au/journals/ NSWJSchol/2014/13.pdf [last viewed 14.01.2019].

4. Cossart, S., Chaplier, J., Beau de Loménie, T. The French Law on Duty of Care: A Historic Step Towards Making Globalization Work for All. Business and Human Rights Journal, Vol. 2, Issue 2, July 2017, pp. 317-323.

5. The Duty of Care of Public Authorities. Available: https://www.researchgate.net/publication/ 314732215_The_Duty_of_Care_of_Public_Authorities [last viewed 20.01.2019].

6. The General Principles of EU Administrative Procedural Law. In-depth Analysis. European Parliament. Directorate General for Internal Policies, Policy Department C: Citizens' Rights and Constitutional Affairs. The Committee on Legal Affairs, 2015. Available: http://www.europarl. europa.eu/RegData/etudes/IDAN/2015/519224/IPOL_IDA\%282015\%29519224_EN.pdf [last viewed 17.10.2018].

7. Lunz, H. The Duty of Care of Public Authorities. Presentation. January 2006. Available: https://www. researchgate.net/publication/314732215_The_Duty_of_Care_of_Public_Authorities [last viewed 14.01.2019].

\section{Normative Acts}

1. Administratīvā procesa likums [Administrative Procedure Law]. Available: https://likumi.lv/ta/ $\mathrm{id} / 55567$-administrativa-procesa-likums [last viewed 20.06.2019].

2. Valsts pārvaldes iestāžu nodarīto zaudējumu atlīdzināšanas likums [Law on Compensation for Losses Caused by State Administration]. Available: https://likumi.lv/ta/id/110746-valsts-parvaldesiestazu-nodarito-zaudejumu-atlidzinasanas-likums [last viewed 20.06.2019].

3. Valsts pārvaldes iekārtas likums [State Administration Structure Law]. Adopted 06.06.2002. Available: https://likumi.lv/doc.php?id=63545 [last viewed 20.06.2019].

4. Likums "Par policiju” [Republic of Latvia law "On Police"]. Available: https://likumi.lv/ta/id/67957par-policiju [last viewed 20.06.2019].

5. Charter of Fundamental Rights of the European Union. (2016/C 202/02). Available: https://eur-lex. europa.eu/legal-content/LV/TXT/?uri=CELEX\%3A12012P\%2FTXT [last viewed 17.10.2018].

6. Likums "Par Līgumu par Protokola par Eiropas Kopienu privilēgijām un imunitātēm izpildīšanu Latvijas Republikä" [Republic of Latva law "Agreement Implementing the Protocol on the Privileges and Immunities of the European Communities in the Republic of Latvia]. Available: https://likumi. lv/ta/id/88809-par-ligumu-par-protokola-par-eiropas-kopienu-privilegijam-un-imunitatemizpildisanu-latvijas-republika [last viewed 20.06.2019].

\section{Recommendations}

1. Recommendation $\mathrm{CM} / \operatorname{Rec}(2007) 7$ of the Committee of Ministers to member states on good administration. (Adopted by the Committee of Ministers on 20 June 2007 at the $999 \mathrm{bis}$ meeting of the Ministers' Deputies). Available: https://rm.coe.int/16807096b9 [last viewed 14.01.2019].

\section{Case Law}

1. Republic of Latvia Supreme Court judgment of 26 June 2008 in case No. SKA-155/08, para. 30. Available: www.at.gov.lv [last viewed 14.01.2019]. 
2. Republic of Latvia Supreme Court judgment of 20 April 2012 in case No. SKA-372/12, para. 13. Available: www.at.gov.lv [last viewed 14.01.2019].

3. Administrative case No. A420697010. Unpublished.

4. Judgement of 10 May 2001 of the European Court of Human Rights in case T. P. and K. Mv. the United Kingdom, No. 28945/95, para. 46. Available: https://hudoc.echr.coe.int [last viewed 14.01.2019].

5. Judgement of 28 October 1998 of the European Court of Human Rights in case Osman v. United Kingdom, No. 23452/94. Available: https://hudoc.echr.coe.int [last viewed 14.01.2019].

6. Judgement of 21 December 2010 by the European Court of Human Rights in case Jasinskis v. Latvia. Latvijas Vēstnesis, No. 196(4594), 14.12.2011.

7. Judgment of the Court of Justice of the European Union in case No. C-220/13 P, para. 25 and 69, case No. C-496/08 P, paras. 28 and 60. Available: www.curia.europa.eu [last viewed 17.10.2018].

8. The Court of Justice of the European Union judgment of 4 April 2017 in case No. C-337/15P, para. 34. Available: www.curia.europa.eu [last viewed 17.10.2018].

9. The Court of Justice of the European Union judgment of 9 November 2017 in case No. C-46/16, para. 54-56. Available: www.curia.europa.eu [last viewed 17.10.2018].

10. The Court of Justice of the European Union judgment of 10 September 2015 in case No. C-687/13, para. 46. Available: www.curia.europa.eu [last viewed 17.10.2018].

11. The Court of Justice of the European Union case No. C-184/16, opinion of Advocate-General M. Szpunar, para. 72. Available: www.curia.europa.eu [last viewed 17.10.2018].

12. The Court of Justice of the European Union case No. C-684/16, opinion of Advocate-General Y. Bot, para. 40. Available: www.curia.europa.eu [last viewed 17.10.2018].

13. Application to the Court of Justice of the European Union, case No. T-778/16. Available: www.curia. europa.eu [last viewed 17.10.2018].

14. The Court of Justice of the European Union case No. C-587/17P, opinion of Advocate-General N. Wahl, para. 94.

15. Judgment of 7 November 2013 of the US Supreme Court.

16. Opinion of Advocate General Bot delivered on 29 May 2018 in case No. C-684/16 (para. 40) and C-619/16 (para. 42) of the European Court of Justice. Available: www.curia.europa.eu [last viewed 17.10.2018].

\section{Other Sources}

1. LZA Terminolog̣ijas komisijas akadēmiskā terminu datubāze AkadTerm [Latvian Academy of Sciences academic terminology database AkadTerm]. Available: http://termini.lza.lv/term. php?term=duty\%20of\%20care\&lang=EN [last viewed 17.10.2018].

2. The General Principles of EU Administrative Procedural Law. In-depth Analysis. European Parlament. Directorate General for Internal Policies, Policy Department C: Citizens' Rights and Constitutional Affairs. The Committee on Legal Affairs, 2015, p. 12. 


\title{
Collateral in Public Register as a Security of Private Debt
}

\author{
Dr. iur. Jānis Rozenfelds \\ Faculty of Law, the University of Latvia \\ Professor \\ E-mail: Janis.Rozenfelds@lu.Iv
}

This article deals with approaches to establishment of the collateral. Registration in public registers is a precondition to establish a mortgage and a commercial pledge, where the first one is recorded in the Land Register, while the second - in the Register of Commercial Pledges. Unlike the mortgages, execution of rights to a commercial pledge depends not only on registration, but also on whether a pledgee has taken actual possession of property. Taking of possession has not been expressly set forth by Latvian laws. It is necessary to specify the moment in legal acts when the pledged property was actually taken into possession.

The subject of a mortgage is immovable property. The subject of a commercial pledge is movable property. Immovable property cannot be the subject of a commercial pledge. Distinction between movable and immovable property may lead to a situation when a holder of the commercial pledge loses the collateral due to the fact that the subject of pledge, once moveable, has turned into immovable property.

The collateral is also endangered by the fact that public reliability is not necessarily always attributed to all public registers in all situations. Legal regulation of the register of commercial pledges more corresponds with the principle of public reliability. This principle, however, is not clearly defined for land registers and is variously interpreted by courts, thus leaving negative influence upon the stability of pledge rights.

It is highlighted in Latvian law that existence of the collateral depends on whether there is a claim secured by a pledge (accessoriness). Current practise differs from that in the interwar period in Latvia. The difference lies within such secured claims that cannot be executed by force due to the limitation period or other reasons. Such changes in practise have led to the situation when secured claims may not be executed in case of insolvency of a debtor if the creditor has been in default to apply his claim within the term set by the insolvency administrator.

Keywords: accessoriness, collateral, mortgage, commercial pledge, possession, secured creditor, insolvency, movable, immovable, registration.

\section{Contents}

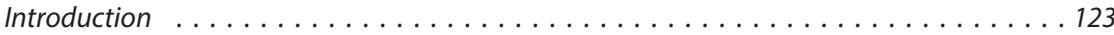

1. Establishing of Collateral Through Taking Possession of Property . . . . . . . . 124

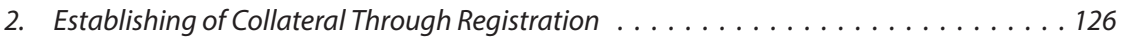

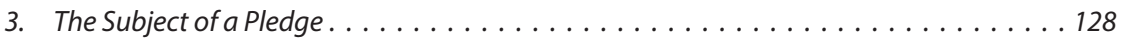

4. Reliability of Public Registers . . . . . . . . . . . . . . . . . . . . . . 131 
5. Accessoriness Between the Loan and the Pledge . . . . . . . . . . . . . . 133

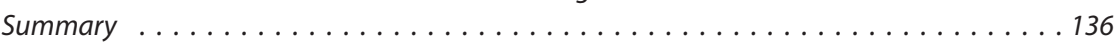

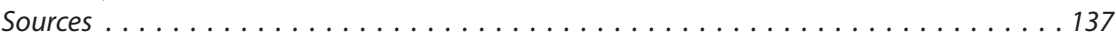

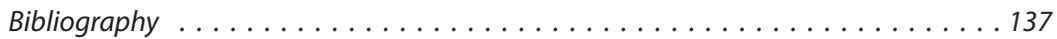

Case Law . . . . . . . . . . . . . . . . . . . . . . . . . . . . 137

Other Sources . . . . . . . . . . . . . . . . . . . . . . . . . . . 137

\section{Introduction}

Establishing of the collateral is regulated by the Latvian Civil Law (CL), by the Law on Commercial Pledge and by the Financial Collateral Law.

Section 1279 of the CL provides two different ways to establish the collateral: possession and registration. The result would be a possessory pledge and a mortgage respectively.

The Law on Commercial Pledge provides for more complex way to establish the pledge which is a combination of registration and taking of actual possession. The result would be a commercial pledge.

Possession is regarded as a specific way to establish an unregistered possessory pledge. A possessory pledge can be established over a movable property by establishing (if the movable property is delivered in order to establish possessory pledge) or by maintaining physical control (if the movable property is already under physical control of the pledgee, i.e. a landlord) over the property (sections 878-908 of CL).

Immovable property or a ship can be mortgaged by registration in the Land Register or in the Ship Register respectively. In both cases registration alone constitutes mortgage with immediate effect for the pledger as well as for third parties.

Registration in the Land Register is regulated by the Land Register Law and by the law On Recording of Immovable Property in the Land Registers. Registration in the Ship Register is regulated by the Maritime Code and by Regulations Regarding Registration of Ships in the Latvian Ship Register.

Terms of the delivery and loss of the possession prescribed by the CL are extremely complicated and sometimes contradictory due to which they were widely criticised. ${ }^{1}$ These terms are also very formal.

As composed under the domineering influence of Savigny's concept of two key elements of possession - corpus possessionis and animus possidendi ${ }^{2}$ - the above rules heavily rely on the possession's subjective element as well. An inevitable consequence of taking over as well as losing of possession under the CL is not only by acquiring or losing the actual physical control over property but also by changing one's subjective attitude towards his or her actual possession as such.

If property is already under the control of a person, then he or she shall acquire possession simply by his or her intention to possess it as his or her own (section 886 of CL).

1 Cvingmans, O. Valdišanas šolaiku tiesībās [Possession in contemporary law]. Tieslietu Ministrijas Vēstnesis, No. 1, 1926; Vìnzarājs, N. Valdījuma sastāvs. Civiltiesību problēmas [Composition of possession. Problems of civil law]. Compiled by E. Kalniņš. Rìga: Erlens Kalniņš un Viktors Tihonovs, 2000, p. 66; Rozenfelds, J. Valdijuma teorijas [Possession theories]. In: Latvijas Universitātes Zinātniskie raksti. Vol. 740. Rīga: University of Latvia Press, 2008.

2 Rozenfelds, J. Valdijuma teorijas [Possession theories]. In: Latvijas Universitātes Zinātniskie raksti. Vol. 740. Riga: University of Latvia Press, 2008. 
A person who possesses property in his or her own name may also commence to possess it according to his or her own discretion as the substitute for another person, albeit the latter has not taken it under his or her control (section $890 \mathrm{CL}$ ).

As the same rules for acquiring possession apply to establishing of a pledge, the only precondition for establishment of a pledge is that possession of the pledged property is transferred to the creditor (the pledgee).

This was one of the main reasons why the possessory pledge, which can be established by possession alone (i.e., without any registration), caused problems in practice. $^{3}$ The unregistered pledge has been withdrawn from circulation and nowadays is not used except for some pawn shops.

Unfortunately, the aforementioned principles for taking over possession apply to the commercial pledge, as well. This brings about undesired consequences into the procedures carried out by the Register of Commercial Pledges.

The subject of the commercial pledge can be anything except immovable property, ships or financial assets (because the first one can only be mortgaged by registration in the Land Register and Ship Register respectively, but the latter exclusively as a financial pledge).

Establishing of the financial pledge is regulated by the Financial Collateral Law in the result of implementation of Directive 2002/47/EC.

As it is a common practice to establish a commercial pledge over the whole assets of the commercial entity (sometimes called a floating charge), it is important to establish the exact time for taking over the aforementioned assets in case the pledgee is obliged to seize the same assets in order to regain debt from the auctioned price. Such takeover can happen immediately after or even before registration of the commercial pledge. However, in the majority of cases such takeover is only a remote probability which should take place in case the debtor, whose debt is secured by pledge, is in default. Such time gap between registration of a commercial pledge and taking over of the pledged items exists because the pledger is usually interested in retaining his or her control over the pledged assets during the life time of the collateral.

The status of a pledger of the commercial pledge is of some significance as well. There are two different types of pledgers.

Only a legal entity can pledge all assets as an aggregation of property as a commercial pledge (section 1, paragraph 3; section 3; section 3 part (3); section 10, part (3) of the Law on Commercial Pledge, section 1303 of the CL).

Individuals can only pledge movable property that is subject to registration: land transport vehicles, aircraft and animals and herds as well as patents, trademarks and registered designs to be registered with relevant national registers.

\section{Establishing of Collateral Through Taking Possession of Property}

The main feature which distinguishes a commercial pledge from a possessory pledge or a pawn is that the first one needs to be registered with the Register of Commercial Pledges run by the Company Register (section 2 of the Law of Commercial Pledge), but the latter is established by simply taking possession of property (section $1279 \mathrm{CL}$ ).

3 Rozenfelds, J. Legal Framework of Commercial Pledge in Latvia. In: Latvijas Universitātes 72. zinātniskās konferences rakstu krājums “Tiesību efektīva piemērošanas problemātika”. Rīga: University of Latvia Press, 2014, p. 13. 
Since those categories of property that cannot be registered anyway exceed those which can be, one would expect that only the latter are regarded as a subject of the commercial pledge. This is not true. There is indeed a clause in the Law on Commercial Pledge, which deals with so-called recordable property in a specific way (section 1 part 3 of Law on Commercial Pledge). However, this law does not preclude parties from pledging a variety of property, both tangible and intangible, that cannot be registered in any way.

This is achieved by a simple trick - any legal entity is able to register any property - tangible as well as intangible or even the whole assets as an aggregation of property (section 3, part (3) of the Law on Commercial Pledge). In this case, registration means filling in certain paper form and filing it with the register. The register shall not follow up whether the particular property was ever materialized. This means that the key in establishing the pledge right lies not with registration, as it is 'registration' by name only, but in actual taking of the pledged property in actual possession by the pledgee.

Actual possession of property can take place at the moment when the collateral is established (which would be a rare occasion though) or only at the moment when the debtor is in default, and this entitles the creditor to sell the pledged property. Since the pledged movable property remains under physical control of the pledger until the pledgee decides to take over assets of the pledgee, he or she is free to alienate this particular property or all his or her belongings at any time unless the property is taken over by the pledgee. If the pledge agreement is concluded and performed in such a way, the risk of losing his or her rights in the pledged property is completely with the pledgee.

Technically, however, the pledged property remains in the possession of the pledgee. Even if the latter never touched anything, the rules for taking over possession are flexible enough to allow possession continue as long as the pledgee keeps an intention to possess. These rules are not specified by the Law on Commercial Pledge. Thus, the general principles for taking over and maintaining possession as provided by the CL are at work here. In practice it means that the pledged property remains in full control of the pledger. He or she is considered as a 'substitute' of the possessor, i.e. the pledgee.

In order to acquire possession through a substitute, it is necessary that the person being substituted for actually has such intention [to keep the property for another person - J. R.] (section 888 of CL).

Formally the pledger cannot alienate the pledged property without written permission by the pledgee (section 34 of the Law on Commercial Pledge).

It is a criminal offence if a person commits alienation of property pledged by way of commercial pledge without the authorisation of the pledge (section 216 of the Criminal Law).

However, a person may be brought to such liability only under certain additional qualifications, i.e., if substantial harm has been caused thereby to the property interests of the pledgee or other persons and if indeed the sale has taken place without permission. It is still doubtful though whether absence of such permission would be proven if the pledger was engaged in trade with the property subject to the collateral. If accused in illegal sale of the property, the pledger can always claim that he or she considered that the permission for sale was implied in the agreement.

Apparently, such system works only thanks to reliability of the pledger and the mutual confidence with the pledgee. 
In order to improve this fairly unreliable system, it would be advisable to introduce provisions that would restrain the pledger from alienation of the pledged movables property without consent of the pledgee, e.g. by putting certain time frame during which the pledgee could claim restitution of the alienated pledge. Such provisions would make any third person as a buyer vigilant enough to obtain permission of the pledger. It would also be helpful either to introduce some restrictions over acquisition of possession and in this way give up the notorious constitutum possessorium as a way for acquisition of possession (or abandoning it) by changing one's mind alone. If this would seem too drastic means (proposed already more than 80 years ago but still left without notice even during the new codification back in 1937), then at least it would help to put some restrictions for using this very discreet method for acquiring possession in order to establish the possessory pledge.

\section{Establishing of Collateral Through Registration}

Registration is a precondition for establishing of a mortgage as well as a commercial pledge. Mortgaged objects can be immovable property, as well as ships. Recently, it has however turned out that regulations are not clear enough to distinguish between the construction permanently attached to the land (i.e., immovable property) and a ship. ${ }^{4}$

There are three different registers that may be used to establish a registered pledge: Land Register, Ship Register and Register of Commercial Pledges.

The most common form of registered collateral is a mortgage. The object of registration or corroboration can be immovable property (sections 992, 994 of CL), land (sections 1004, 1042, 1070, 1073, 1075, 1082, 1087, 1088-1096, 1099-1101, 1108-1110, 1117, 1124, 1127, 1143, 1163, 1166, 1170, 1181, 1186, 1200, 1210 of CL), a 'parcel of land' (sections 1121, 1127, 1130, 1159, 1161, 1164, 1182, 1183, 1197, 1216, 1222, 1223, 1224 of CL) or a 'mortgageable parcel' (section 993 of CL). As regards establishment of the mortgage, the CL distinguishes between a parcel of land and a building (section 1299 of CL).

Only the first term (immovable property) may be regarded as scientifically adequate. $^{5}$

The registration of a mortgage in the Land Register may only be made at the Land Register office in whose administrative area the immovable property is located (section 1369 of CL).

Registration of pledge rights in the Land Register shall only be allowed with the consent of the pledger, which he or she has expressed either in establishing the pledge right or subsequently. This provision does not apply to those cases where the pledge right is registered on the basis of the judgment or decision of a court (section 1372 of CL).

A mortgage shall only be registered in the Land Register for a specific amount of money and in regard to a specific immovable property, the owner of which designated in such Register is the pledger (section 1373 of CL).

4 Čepāne, I. Kug̣is vai māja - tāds ir jautājums [A ship or a building - that is the question]. Jurista Vārds, No. 15(1021), 2018, pp. 14-21.

5 Būmanis, A. Piezīmes pie B. Disterlo k-ga raksta par terminologiju likumdošanā [Notes to B. Disterlo's article on terminology in legislation]. Tieslietu Ministrijas Vēstnesis, No. 4, 1936. 
Registration in the Land Register is the necessary precondition to establish mortgage rights. However, there is also another kind of registration which is carried out in the Cadastre Information System in accordance with the National Real Estate Cadastre Law. Registration in this system predates the Land Register and may be traced back to the registration system which existed during the Soviet occupation.

During the land and property reform when the Land Register either did not exist (it was re-established in 1993) or did not succeed in registering all existing rights, it was a common practice to rely on the data provided by the Cadastre Information System. This practice was widespread in dealing with residential property or apartments (section 7 of the National Real Estate Cadastre Law).

The role of the Cadastre Information System was crucial in establishing whether there was a statement from the local government that the particular construction was not registered with the local government in the name of another person until 5 April 1993 in accordance with the Law On Renewal and Procedures for Coming into Effect of the Land Register Law of 22 December 1937 (section 44 of the National Real Estate Cadastre Law).

Before registration of a mortgage, it is important to examine whether there is not any person's interest in the land which has existed before registration of the mortgage. If this is the case, the litigation over implementation of the mortgage cannot be excluded.

However, at least in theory the Cadastre Information System provides information for taxation, while the Land Register consists of rights in rem.

Requests for corroboration shall be in writing (section 56 of the Land Register Law). A request for corroboration, which has been signed in accordance with the procedures laid down in the laws and regulations regarding electronic documents, shall be submitted by a sworn notary, if the corroboration is based on a notarial deed prepared by such sworn notary (section $56^{1}$ of the Land Register Law).

Registration of a commercial pledge takes place in the Register of Commercial Pledges. Application may be submitted as an electronic document. It may also be delivered in person. In such case, the identity of the deliverer is certified by the staff of the register. The notary can certify a power of attorney issued by the pledger to a third person (section 14 of the Law on Commercial Pledge).

Similar rules apply to registration of a mortgage to the ship (section 16 of the Cabinet Regulations No.467 Regarding Registration of Ships in the Latvian Ship Register adopted on 6 June 2006).

The so-called recordable movable property (except ships) include all kinds of property from vehicles to pets. There are about a dozen of registries dealing with registration of such movable property.

Special kind of intangible recordable property is intellectual property (IP).

The right to an invention based on a patent or the application thereof shall, according to the legal treatment, be regarded as equal to the right to the movable property. The property rights associated with the patents and patent applications may be inter alia the subject of a pledge (section 50 of the Patent Law). Similar clauses are included in the special laws on trademarks (section $25^{1}$ of the Law on Trade Marks and Indications of Geographical Origin) and designs (section 41 of the Law on Designs). Until 2016, the Patent Board of Latvia also dealt with registration of pledges. Due to amendments in the Law on Commercial Pledge, the intellectual property is now treated as a variety of movable property and as such may be registered as a commercial pledge in the Register of Commercial Pledges. The Patent 
Board does not register these items as pledges but is being noticed about such registration. Only national registration and registration with EPO, if the registered patent applies to Latvia as a member state of EPO, can become the subject of the commercial pledge. IP can be regarded as the subject of the commercial pledge only under condition that it is expressly mentioned in the application for registration of the commercial pledge. It will not be accepted as the subject of a commercial pledge to be a part of the aggregation of property (section 10, part (3) of the Law on Commercial Pledge).

\section{The Subject of a Pledge}

Since only immovable property can be mortgaged and only movable property (except ships) - pledged as a commercial pledge, it is important to distinguish the former from the latter.

It is not always possible to draw a fine line between two kinds of property which are subject to two different systems of registration. The problem with this regulation as provided by the CL is that it does not meet strict scientific criteria for classification of movable and immovable property.

There are properties which, albeit movable by their appearance, could be regarded as an inalienable element or a part of immovable property by their location and specific role towards the immovable property - the so-called auxiliary property or appurtenances.

The CL puts forward three different criteria for "auxiliary property". Auxiliary property "acquires the character of an appurtenance, if its function is to serve the principal property, it is permanently connected with it and pursuant to its natural characteristics it corresponds to this function" (section 857 of CL).

Then there are properties which, albeit immovable by their appearance, can be regarded as movable due to special exceptions provided by law. These are small buildings, surface and underground utilities, temporary engineering structures, which shall not be recorded in the Land Register in accordance with section 19 of the law On Recording of Immovable Property in the Land Register.

Still there is more complex problem with items which although inseparably connected to the land nevertheless could be regarded either as immovable property belonging to another person (section 14 of the Law on Time and Procedures for Coming into Force of Introduction, Inheritance Law and Property Law Part of the Renewed Civil Law of the Republic of Latvia of 1937) or as the so called "dual property," 6 and registered as an independent immovable property. ${ }^{7}$

As the subject of a commercial pledge can only be movable property (immovable property is excluded by section 3 of the Law on Commercial Pledge), the blurring distinction line between movable and immovable property has provided opportunity to get rid of the burden of the registered commercial pledge by the pledger who has transformed assets of the wind power station initially pledged as movable property and registered as a commercial pledge, and afterwards turned into immovable property with disastrous consequences for the unsuspecting pledgee. ${ }^{8}$

6 Rozenfelds, J. Property Law. The Law of Baltic States. Eds. T. Kerikmäe, K. Joamets, J. Pleps, A. Rodina, T. Berkmanas, E. Gruodyte. Cham: Springer International Publishing AG, 2017, p. 279.

7 Rozenfelds, J. Reform of Land Registration in Latvia. Juridica International. Law Review, Vol. 22. Estonia: University of Tartu, 2014, pp. 43-50.

8 Case No. C33382113. Available: https://www.google.lv/search?q=C33382113\&ie=utf- $8 \&$ oe $=u t f-8 \&$ client=firefox-b-ab\&gws_rd=cr\&dcr=0\&ei=Kx6xWvTIKazagAac_In4Bg [last viewed 20.03.2018]. 
One of the difficulties for classification of property as provided by the CL is that distinction of movable and immovable property is incompatible with that of tangible and intangible property.

As only tangible property is regarded by the CL as movable or immovable (section 842 of CL), it seems at the first glance that so-called intangible property like claims, IP objects etc. cannot be pledged altogether. However, the CL somehow circumvents this obstacle and provides that claims as well as other intangible property may be pledged eventually.

Law on Commercial Pledge treats this issue in a specific way. It provides that each claim by a legal entity can be pledged as a separate commercial pledge or all claims can be pledged as a part of aggregation of property. In the latter case the commercial pledge would not only apply to the already existing claims but also to future ones.

The exact number and amount of pledged claims in such case would be fixed only if and when the pledgee finds it necessary to exercise his or her pledge rights.

A person, who accepts as a pledge a claim on debt against a third person, must inform such third person in order that he or she not repays the debt to his or her direct creditor (section 1335 of CL).

If, in such a case the debtor does not make payment within the set period of time, the pledgee has the right to claim for recovery from the third person who is in debt to the debtor of the pledgee, or to cede his or her claim by selling it to another (section 1336 of CL).

The problem with the regulation as provided by the Law on Commercial Pledge may arise when it comes to weather and when the pledgee of the commercial pledge has taken over pledged assets. As provided by the Law on Commercial Pledge, such take-over can happen at the moment of registration of the commercial pledge with immediate effect or, if this is not the intension of the parties, then taking over of the pledged assets can happen at the moment when the pledgee has to sell the pledged assets due to the pledger's default on his or her obligations (section 36 part (2) of the Law on Commercial Pledge).

Commercial pledge of all assets of the pledger is even more complex.

Pledge of all assets (floating charge) as provided by the CL was already put under scientific examination. ${ }^{9}$ According to the view by Mr. E. Kalniņš, there are two significant flaws in this regulation.

First of all, the very term for an aggregation of property is unclear.

An aggregation of property is such collection of several items of property, selfcontained, of one or more classes, tangible or intangible, for a known purpose, in a unitary composition and with one joint designation as shall be acknowledged in a legal sense as a whole, or a unitary property. The concept of an aggregation of property, and its essence, shall not be destroyed or altered either by the reduction or augmentation of the separate items of property incorporated in its composition, or any other change in them (section 849 of CL).

In view of Mr. E. Kalniņš, such a broad definition of an aggregation of property brings at least two uncertainties.

9 Pētijums par Civillikuma lietu tiesību daḷas pirmās, otrās un trešās daḷas modernizācijas nepieciešamïbu [Research on necessity to update Chapters I, II and III of Property Law Section of the Civil Law], 2008. Available: https://www.tm.gov.lv/lv/nozares-politika/petijumi [last viewed 24.04.2018]. 
Firstly, such definition contradicts with the so-called principle of speciality which provides that only certain tangible things can be regarded as property. ${ }^{10}$

Secondly, section 849 of the CL does not make any distinction between tangible and intangible things as is the case in Roman law where there are two kinds of aggregation of property - one which consists only of tangible items (universitas rerum) and another which consists only of intangible items (universitas iuris). ${ }^{11}$

Thirdly, the wording of the CL runs into irresolvable controversy by stating that an item as a property cannot be at the same time intangible and movable or immovable as it declares that "when intangible property is treated as a constituent part or appurtenance of tangible property, then it assumes the characteristics of the latter and in accordance therewith, shall be considered either moveable or immovable" (section 846 of CL). In the result of what is stated under section 846 of the CL, the latter becomes incompatible with section 842 of the CL stating that "tangible property is either moveable or immovable".

As stated by the CL, "a pledge right, the subject of which is an aggregation of property, applies not only to the already existing but also to future, and not only to tangible but also to intangible parts of such aggregation, provided that it is not clearly evident that the intention of the pledger was only to pledge such aggregation of property as was constituted when the pledge was given" (section 1303 of CL).

Still, the proposal by Mr. E. Kalniņš to change the wording of section 846 of the $\mathrm{CL}^{12}$ was not approved.

The same flaws apply to the pledge rights, if an aggregation of property is at issue. ${ }^{13}$

Combined with another controversial clause which allows symbolic takeover (the so called constitutum possessorium), this regulation, if applied to an aggregation of property of the legal entity, turns the real take-over of the pledged assets into mere paper work the result of which is hardly noticeable by third persons as 'registered' in the Company Register.

The above mentioned flaws in regulation of the commercial pledge have led Mr. Kalniņš, who earlier was criticising this mechanism, to conclude that the commercial pledge of the whole assets by the legal entity is translating itself only in a form of a transaction that has never reached the stage of handing over (transition) the pledge to the pledgee. ${ }^{14}$

Given that the criteria for distinction between movable and immovable property are uncertain, it would be necessary to fill in the gaps thus taking away from unscrupulous pledgers the opportunity to get away from the undertaken liability by turning movable property into immovable and vice versa. In order to avoid this uncertainty, it would be necessary to introduce a provision that after any particular property - movable or immovable - is pledged as a commercial pledge or mortgage respectively, the status of such property cannot be changed until the end of duration of the respective pledge right.

10 Pētījums par Civillikuma lietu tiesību daḷas pirmās, otrās un trešās daḷas modernizācijas nepieciešamïbu [Research on necessity to update Chapters I, II and III of Property Law Section of the Civil Law], 2008. Available: https://www.tm.gov.lv/lv/nozares-politika/petijumi [last viewed 24.04.2018], p.9.

11 Ibid.

12 Ibid., p. 9.

13 Ibid., p. 10.

14 Kalniņ̌̌s, E. Laulāto manta laulāto likumiskajās mantiskajās attiecībās [Property of spouses in lawful property relations of spouses]. Rìga, 2010, p. 34. 


\section{Reliability of Public Registers}

Since reinstatement of the Civil Law back in 1992, the case law is struggling to find the right balance between protection of the bona fide acquirer of the immovable property and the ancient principle of causation meaning that no one can transfer more rights (to another) than they are having themselves.

The observation made just a couple of years ago that "courts have departed from the strictly observed provision in the pre-war literature and judicial practice that the sole criterion to dispute the good faith of an acquirer of the immovable property may be the defects that could be learned from the record in the land register"15, can be also attributed to the cases of later origin, although quite a few court decisions may be found where a court has considered acquisition in good faith as sufficient grounds for the defendant even if the underlying transaction for acquisition of ownership rights should be declared invalid.

So, the main problem in reliability of public registers is unpredictability of the outcome when the above-mentioned reliability should pass the test at court.

Reliability of the Land Register of Latvia was also examined by the European Court of Human Rights, who found that Latvia has not fulfilled the obligation "that the authorities have to put in place an effective exchange of information in order to ensure the reliability of public data". ${ }^{16}$

This, however, did not preclude the Constitutional Court of Latvia from not only deciding that "grounds for concluding that in Latvia's situation a regulation that differs from the approach to protection of a bona fide acquirer existing in other countries is admissible", ${ }^{17}$ but it also actively defended rightfulness of the same decision.

It does not improve faith in reliability of the Land Register. It comes without saying that if reliability on the Land Register data regarding ownership rights is shattered, the reliability on the data regarding mortgages registered in the same Land Register, albeit in different section, is not better either.

It also does not help that the principle of protection of the acquirer in good faith is not expressly stated in any Latvian law. Consequently, legal scientists have usually deducted this principle from section 1 of the Land Register Law and section 994 of the CL. ${ }^{18}$

The Land Register alone is a poor protection for the acquirer if something turns out to be incorrect. In such a case not only multiple exceptions provided by other laws (in the case No. 2016-07-01, there was a very specific exception provided by sections 356(2) and 360(1) of the Criminal Procedure Law), but also provisions on transfer of property provided by the CL turn out to be contradictory and in part

15 Rozenfelds, J. İpašuma prasība [Ownership Claim]. Journal of the University of Latvia. Law, No. 6. Ed. in chief J. Lazdiņš. Rìga: University of Latvia, 2014, p. 95.

16 Case of Dzirnis v. Latvia. Available: https://hudoc.echr.coe.int/eng\#\{\%22itemid\%22:[\%22001170461\%22] [last viewed 05.04.2018].

17 Judgement on Behalf of the Republic of Latvia in case No. 2016-07-01, 8 March 2017, Riga. Available: http://www.satv.tiesa.gov.lv/wp-content/uploads/2016/05/2016-07-01_Spriedums_ ENG.pdf [last viewed 05.04.2018].

18 Pētījums par Civillikuma lietu tiesību daḷas pirmās, otrās un trešās daḷas modernizācijas nepieciešamību [Research on necessity to update Chapters I, II and III of Property Law section of the Civil Law], 2008, p. 24. Available: https://www.tm.gov.lv/lv/nozares-politika/petijumi [last viewed 09.04.2018]. 
unclear. ${ }^{19}$ We cannot find anything remotely similar to the presumption that "If a right has been entered in the Land Register for a person, it is presumed that the person is entitled to this right" (found in BGB $\$ 891^{20}$ ) in any law of Latvia.

Situation with a commercial pledge seems to be better. The Register of Commercial Pledges is run by the Company Register. The latter is also responsible for maintaining the Company Register which, in turn, is dealt with by the Commercial Law. Both include regulations which significantly differ from those of the CL with respect to consequences if publicly available information provided by the Company register turns out to be incorrect.

Section 12 part (1) of the Commercial Law provides that entries in the Commercial Register shall be in effect as to third parties from the date of their publication. This provision shall not apply to legal activities, which are performed within 15 days following the promulgation of the entry, insofar as the third party can prove that he or she did not know or could not have known the relevant information.

Section 33(2) of the Law on Commercial Pledge provides that the data of the Register of Commercial Pledges towards third persons shall be regarded correct and the third persons shall not be under duty to examine lawfulness of the said data.

These two above mentioned regulations make clear distinction between reliability of public data and vulnerability of the underlying right which depends on lawfulness of the relevant private transactions to certain extent.

Nevertheless there is at least one particular case where referring to reliability of public data of the Company register did not spare the acquirer of the company's immovable property from defeat in the court by the rightful heir of the same property (that was alienated by the director of the company by forging signature of the deceased CEO of the same company). ${ }^{21}$

However, as a rule the pledgee can successfully defend him/herself against claims based on invalidity of ownership rights of the pledger. ${ }^{22}$

As there is no distinction between registered ownership right and registered pledge right, the consequences arising out of the mistake in the public register are equally applicable to the registered mortgage.

The Supreme Court has confirmed that the principle of reliability of the Land Register (section 1 of the Land Register Law and section 994 of CL) is applicable to the pledgee. ${ }^{23}$ Due to the fact that fraudulent transactions leading to unfair loss of property keep reappearing rather frequently, protection of the pledgee's interests, that is usually a bank, sometimes causes public outcry when such decision is regarded as unfair. In one of the recent $\operatorname{cases}^{24}$ the public condemnation against the

19 Rozenfelds, J. Ownership Acquired in Good Faith. Journal of the University of Latvia. Law, No. 10. Ed. in chief J. Lazdiņš. Riga: University of Latvia, 2017, pp. 63-69.

20 BGB. Available: http://www.gesetze-im-internet.de/englisch_bgb/englisch_bgb.html\#p3671 [last viewed 05.04.2018].

21 Case No. SKC-10/2012. Available: http://www.at.gov.lv/lv/judikatura/judikaturas-nolemumuarhivs/civillietu-departaments/hronologiska-seciba?year=2012 [last viewed 05.04.2018].

22 Ibid.

23 Ibid., last viewed 09.04.2018.

24 Supreme Court decision in case No. C04281907, SKC-284/2017 of December 28, 2017. Unpublished. 
court's decision was so intense that one of the largest credit institutions in Latvia felt compelled to waive its right of mortgage. ${ }^{25}$

A multitude of registrations, which due to different types of fraudulent activities, were declared invalid on regular basis have not led to satisfactory solution of the problem which in the view of the author of this article can be only found by strengthening reliability of public registers. Unfortunately, faced with this problem, the common sense has kind of moved into the opposite direction by subjecting the principle of reliability of public registers to the multiple 'exceptions' that may only lead to deeper erosion of this substantial principle.

What should and could be recorder in the Land Register under Latvian law itself has been a subject for discussion in recent literature, as well as in case law. Generally, though it is acknowledged that rights in rem are recordable, while claims (right in personam) are not.

However, as distinction is not clear-cut, some of the claims have been put under fierce discussion regarding their ability to be registered in the Land Register and to be the subject of mortgage rights. Some of the decisions made by judges of the Land Registry Office have been criticised ${ }^{26}$ and returned by the Supreme Court. ${ }^{27}$

The lingering case law $^{28}$ has not done any good to the common understanding as to which rights are eligible for registration and which are not.

Uncertainty about the right as the subject of registration in a public register has definitely laid negative impact upon reliability of the registered collateral right.

\section{Accessoriness Between the Loan and the Pledge}

The main difference between the various forms of mortgages to be found in Europe lies in the principle of accessoriness, i.e. the linkage of a mortgage to the existence of the secured debt, which applies in the English and French, but not in the German legal family. ${ }^{29}$

The interdependence of the underlying relationship between the debtor and the original creditor was based on the idea of public faith (öfentlicher Glaube) in the public land register, comparable with the law on negotiable instruments. The secured claim and the right of mortgage were laid down in an instrument that, like a bill of exchange, could be transferred easily. This demanded an abstraction from the underlying legal relationship. The secured claim and the right of mortgage had to be valid, despite possible defects in the legal relationship on which the claim and the

25 Pēc "Nekā personīga" sižeta "Swedbank" atsakās no hipotēkas mājai, ko īpašniekam izkrāpa organizēta grupa [After a TV broadcast "Nothing personal", "Swedbank" refuses from a mortgage put on the house which was defrauded from its owner by an organised criminal group]. Available: https://skaties.lv/zinas/latvija/neka-personiga/pec-neka-personiga-sizeta-swedbank-atsakas-nohipotekas-majai-ko-ipasniekam-izkrapa-organizeta-g [last viewed 11.04.2018].

26 Virko, E. Zemesgrāmatu pieejamība un ticamība (I) [Availability and credibility of land registers]. Jurista Vārds, No. 13(518), 2008; Virko, E. Zemesgrāmatu pieejamība un ticamība (II) [Availability and credibility of land registers]. Jurista Vārds, No. 15(520), 2008.

27 Case No. SKC-1800/2012. Available: http://at.gov.lv/lv/judikatura/judikaturas-nolemumu-arhivs/ civillietu-departaments/hronologiska-seciba?year=2012 [last viewed 20.04.2018].

28 Case No. SKC248/2017. Available: http://at.gov.lv/lv/judikatura/judikaturas-nolemumu-arhivs/ civillietu-departaments/hronologiska-seciba?year=2017 [last viewed 18.04.2018].

29 Real Property Law and Procedure in the European Union. General Report. Final Version. European University Institute (EUI) Florence/European Private Law Forum Deutsches Notarinstitut (DNotI). Würzburg, p. 17. Available: https://www.eui.eu/Documents/DepartmentsCentres/Law/ ResearchTeaching/ResearchThemes/EuropeanPrivateLaw/RealPropertyProject/GeneralReport. pdf [last viewed 17.06.2019]. 
mortgage were based, and it had to be impossible for the claim and mortgage to be thwarted by defences of which the assignee could not readily know. ${ }^{30}$

Accessoriness between the loan and the pledge was always regarded as undisputed feature of any collateral in Latvian legal doctrine. ${ }^{31}$

However, there is significant difference between the 'ancient' (i.e. the interwar doctrine and practice) and 'contemporary' (i.e. the mainstream doctrine and practice established after reinstatement of the CL in 1992) understanding as to how far-reaching the above-mentioned interdependence between the collateral and secured claim could be and should be.

Most of all the enormity of this shift exposes itself in whether a registered collateral (a mortgage as registered in the Land or Ship Register, as well as a commercial pledge as registered in the Commercial Register) should survive insolvency (as it was during the inter-war period) of the pledger or, on the contrary, insolvency should extinguish rights to the collateral (as it was typical after 1992).

This important turning point in understanding of the interdependence between the collateral and the secured claim has transcended through different understanding of those CL sections which establish accessoriness of the mortgage (sections 1280, 1283 of CL).

Section 1283 of the Civil Law of 1937 has originated from section 1339 of the Civil laws of 1864 (Part III of the Codification of Local Laws or the CLL). ${ }^{32}$

The CLL, in turn, is based on sources of Roman law which were applied in the territory of Latvia by local courts long before it was codified back in 1864 . The author of the above-mentioned codification of 1864 - F. Bunge, supplemented almost each of 4600 articles or sections of the CLL with citations from different sources, preferentially from the Digest of Justinian. The first citation under section 1339 is L. 5,12 et 13 D.de pignor.et hypoth. (XX,1) which by using the modern method of citation would lead to D., 20, 1, 5, 12, 13 respectively.

D. 20, 1, 5 states: "Property can be mortgaged for any obligation [..] [not excluding] natural obligation". ${ }^{33}$

The same approach may be found in literature dealing with the so called modern Roman law. ${ }^{34}$

Sources of law (the CLL and since 1937 - the CL) have regarded the collateral securing a natural obligation as relevant, sufficient right. This was also manifested

30 Vliet, L. van. The German Grundschuld. The Edinburgh Law Review, 16.2, 2012, p. 152.

31 Civillikumi ar paskaidrojumiem. Otrā grāmata. Lietu tiesības [Civil Law with Commentaries. Second book. Property Law.]. Comp. by F. Konradi, A. Walter. Transl. Dr. iur. A. Bümanis, H. Ëlerss, J. Lauva. Rīga: Grāmatrūpnieks, 1935, pp. 309-310. Unofficial edition; Čakste, K. Civiltiesības. Lekcijas. Raksti [Civil law. Lectures. Articles]. Rīga: Zvaigzne ABC, 2011, p. 127.

32 Svod Grazhdanskih Uzakonenij Gubernij Pribaltijskih. Izdanie 1864 goda, so vkljucheniem statej po Prodolzheniju 1890 goda [Codification of Civil law of the Baltic region. Edition of 1864, with amendments until 1890]. S.-Peterburg: Izdanie kodifikacionnogo otdela pri gosudarstvennom sovete, [s. a.]. Available: https://dspace.lu.lv/dspace/handle/7/1209?locale-attribute=ru [last viewed 21.03.2018].

33 Corpus Iuris Civilis. Editio stereotypa tertia. Volumen primum. Institutionas. Recognovit. Paulus Krueger. Digesta. Recognovit. Theodorus Mommsen. Berolini. Apud Weidmannos. MDCCCLXXXII. The Digest Justinian. Translation edited by A. Watson. Vol. 2. Philadelphia: Pennsylvania University of Pennsylvania Press, 1998, p. 124.

34 Baron, Ju. Sistema Rimskogo Grazhdanskogo prava. Vypusk vtoroj. Kniga III. Veshhnoe pravo [Structure of Roman Civil law. Second edition. Volume III]. Transl. L. Petrazhickago. $3^{\text {rd }}$ edition. S.-Peterburg: Sklad izdanija v knizhnom magazine N. K. Martynova, 1908, § 187, pp. 136-137. 
in the court practice during the inter-war period in Latvia as it follows from commentaries to the court practice published back in $1935 .{ }^{35}$

This interpretation means that the creditor's ability to implement the right which is based on the collateral does not necessarily expire in case the underlying debt becomes unenforceable for some reason, i.e. due to the statute of limitation.

Unfortunately, contemporary interpretation of the same section 1283 of the CL is much narrower. It is established by the court practice as well as corroborated in the modern Insolvency law of Latvia of 2009 that with expiry of the statute of limitation not only the creditor's ability to implement his or her right of pledge ceases to exist but also the right to pledge ceases to exist notwithstanding what form was used for establishing such right. This mean that even the mortgage which is duly corroborated in the Land Register (or a commercial pledge which is registered in the Commercial Register) by expiration of the statute of limitation becomes unenforceable but the debtor (or, most commonly, insolvency administrator) is entitled to claim in the court that the above mentioned registration of mortgage is deleted from the Land Register or from the Commercial Pledge Register, respectively.

One may wonder whether such poorly informed creditor could ever exist given that on the one hand, his or her pledge rights are duly registered in the publicly available register, and, on the other hand, the institution who is responsible for the insolvency procedure (the administrator, court) may easily find out whether such publicly registered security existed.

The administrator is under the duty to send a notification regarding the proclamation of insolvency proceedings electronically to all known creditors of the debtor whose right to claim is secured by a commercial pledge, or a mortgage registered in the Land Register or Ship Register (section 141 of the Insolvency Law). The case law, however, provides evidence that there are creditors who have not been duly noticed of the insolvency proceedings.

"If a creditor has missed the deadline for submitting a claim referred to in paragraph 1 of this section, he may submit his or her claim against the debtor within a deadline not exceeding six months from the day when the entry has been made in the Insolvency Register regarding proclamation of the insolvency proceedings of the debtor, but not later than until the day when the plan for settling the creditors' claims has been drawn up in accordance with the procedures laid down in this Law. After this deadline a limitation period sets in, thereby the creditor shall lose his or her creditor status and his or her rights to claim against the debtor" (section 73 of the Insolvency Law).

It means that insolvency can disrupt the mortgage (registered in the Land register for much longer period) or the pledge (registered in the Commercial Pledge Register), as well as the underlying obligation prior to the original expiry term as stipulated by the debtor/creditor agreement and by the Land or Commercial Pledge Register. This provision makes any secured creditor be alert of the debtor's solvency round the clock in order not to lose the security. The creditor who has missed the aforementioned deadline is regarded as 'negligent'. ${ }^{36}$

35 Civillikumi ar paskaidrojumiem. Otrā grāmata. Lietu tiesības [Civil Law with Commentaries. Second book. Property Law]. Comp. by F. Konradi, A. Walter. Transl. Dr. iur. A. Bümanis, H. Ëlerss, J. Lauva. Rīga: Grāmatrūpnieks, 1935, p. 310. Unofficial edition.

36 Bèrziņ̌š, G. Atziņas par aktuālo tiesu praksi maksātnespējas jomā [Conclusions about current court practise in insolvency proceedings]. Jurista Värds, No. 14(917), 2016, pp. 10-16. 
It is difficult to measure effectiveness of the collateral as a security. According to the recovery rate for claims secured by the collateral there are 0.23 euro cents and 0.31 euro cents due from each euro owed by a bankrupt company to secured creditors in 2016 and 2017 respectively. ${ }^{37}$ However, recovery rate for secured claims is significantly higher than 0.04 euro per each owed euro rate for creditors who do not have such security. Low recovery rate may be rather explained by ineffectiveness of the Latvian insolvency procedure (overall cost of recovery of one euro was 2, 17 euro in $2017^{38}$ ) than by accessoriness of the collateral.

Nevertheless, the failure of the registered security right to withstand insolvency of the debtor diminishes the role of the collateral in general and contradicts with the theory and practice of the inter-war period.

Exceptions provided by the Insolvency law also diminish the general principle that the rights registered in the Land Register shall not be subject to prescription. This principle applies not only to registered rights in $\mathrm{rem}^{39}$ but to a certain degree also to claims (rights in personam), if they are registered in the Land Register (section 1907 of CL).

\section{Summary}

In order to improve establishment of the collateral through taking possession of property, it would be advisable to introduce provisions that would restrain the pledger from alienation of pledged movable property without consent of the pledgee, for instance, by setting certain time frame within which the pledgee could claim restitution of the alienated pledge. Such provisions would make any third person as a buyer vigilant enough to obtain permission of the pledger.

It is recommended to clarify provisions for acquisition of possession by disposing of the subjective criteria of the possession that have been abandoned by other systems of law long ago.

Rules for registration of IP as the collateral were changed recently (2016), still, they might turn out to be too complicated.

Pledging of all assets of a legal entity as an aggregation of property (floating charge) could cause misunderstandings as to what was the exact intent of the parties - the pledger and the pledgee.

In order to avoid this uncertainty, it would be necessary to introduce a provision that after any particular property - movable or immovable - is pledged as a commercial pledge or mortgage respectively, the status of such property cannot be changed until the end of duration of the respective pledge right.

Reliability of public registers must be significantly improved.

The principle of accessoriness between the loan and the pledge has led to premature termination of registered mortgage rights in some cases. This practice has diminished reliability of the collateral as a security of obligations.

37 Maksātnespējas administrācijas 2017. gada ziņojums [Report by Insolvency administration of 2017], p. 23. Available: http://www.mna.gov.lv/faili/pub_84.pdf [last viewed 22.03.2018].

38 Ibid., p. 25.

39 Bashmakov, A. A. Osnovnyja nachala ipotechnago prava [Introduction to mortgage rights]. Libava: Izdanie Lito-Tipografii M. Petersona, 1891, pp. 19-20. 


\section{Sources}

\section{Bibliography}

1. Baron, Ju. Sistema Rimskogo Grazhdanskogo prava. Vypusk vtoroj. Kniga III. Veshhnoe pravo [Structure of Roman Civil law. Second edition. Volume III]. Transl. L. Petrazhickago. $3^{\text {rd }}$ edition. S.-Peterburg: Sklad izdanija v knizhnom magazine N. K. Martynova, 1908.

2. Bashmakov, A. A. Osnovnyja nachala ipotechnago prava [Introduction to mortgage rights]. Libava: Izdanie Lito-Tipografii M. Petersona, 1891.

3. Bümanis, A. Piezīmes pie B. Disterlo k-ga raksta par terminoloǵiju likumdošanā [Notes to B. Disterlo's article on terminology in legislation]. Tieslietu Ministrijas Vèstnesis, No. 4, 1936.

4. Civillikumi ar paskaidrojumiem. Otrā grāmata. Lietu tiesības [Civil Law with Commentaries. Second book. Property Law]. Comp. by F. Konradi, A. Walter. Transl. Dr. iur. A. Bümanis, H. Ëlerss, J. Lauva. Rīga: Grāmatrūpnieks, 1935, p. 310. Unofficial edition.

5. Cvingmans, $O$. Valdǐšanas šolaiku tiesībās [Possession in contemporary law]. Tieslietu Ministrijas Vēstnesis, No. 1, 1926.

6. Čakste, K. Civiltiesības. Lekcijas. Raksti [Civil law. Lectures. Articles]. Rīga: Zvaigzne ABC, 2011.

7. Kalniņšs, E. Laulāto manta laulāto likumiskajās mantiskajās attiecībās [Property of spouses in lawful property relations of spouses]. Riga, 2010.

8. Rozenfelds, J. Valdījuma teorijas [Possession theories]. In: Latvijas Universitātes Zinātniskie raksti. Vol. 740. Riga: University of Latvia Press, 2008.

9. Rozenfelds, J. Legal Framework of Commercial Pledge in Latvia. In: Latvijas Universitātes 72. zinātniskās konferences rakstu krājums "Tiesību efektīva piemērošanas problemātika". Rīga: University of Latvia Press, 2014.

10. Rozenfelds, J. Reform of Land Registration in Latvia. Juridica International. Law Review, Vol. 22. Estonia: University of Tartu, 2014.

11. Rozenfelds, J. Ownership Claim. Journal of the University of Latvia. Law, No. 6. Ed. in chief J. Lazdiņš. Rīga: University of Latvia, 2014.

12. Rozenfelds, J. Property Law. The Law of Baltic States. Eds. T. Kerikmäe, K. Joamets, J. Pleps, A. Rodina, T. Berkmanas, E. Gruodyte. Cham: Springer International Publishing AG, 2017.

13. Rozenfelds, J. Ownership Acquired in Good Faith. Journal of the University of Latvia. Law, No. 10. Ed. in chief J. Lazdiņ̌s. Riga: University of Latvia, 2017, pp. 63-69.

14. Vìnzarājs, N. Valdījuma sastāvs. Civiltiesību problēmas [Composition of possession. Problems of civil law]. Compiled by E. Kalniņšs. Rīga: Erlens Kalniņš un Viktors Tihonovs, 2000.

15. Vliet, L. van. The German Grundschuld. The Edinburgh Law Review, 16.2, 2012.

\section{Case Law}

1. Case No. C33382113. Available: https://www.google.lv/search?q=C33382113\&ie=utf-8\&oe=utf8\&client=firefox-b-ab\&gws_rd=cr\&dcr=0\&ei=Kx6xWvTIKazagAac_In4Bg [last viewed 20.03.2018].

2. Case of Dzirnis v. Latvia. Available: https://hudoc.echr.coe.int/eng\#\{\%22itemid\%22:[\%22001$170461 \% 22$ ] [last viewed 05.04.2018].

3. Case No. SKC-10/2012. Available: http://www.at.gov.lv/lv/judikatura/judikaturas-nolemumuarhivs/civillietu-departaments/hronologiska-seciba?year=2012 [last viewed 05.04.2018].

4. Case No. SKC-10/2012. Available: http://www.at.gov.lv/lv/judikatura/judikaturas-nolemumuarhivs/civillietu-departaments/hronologiska-seciba?year=2012 [last viewed 05.04.2018].

5. Case No. SKC-10/2012. Available: http://at.gov.lv/lv/judikatura/judikaturas-nolemumu-arhivs/ civillietu-departaments/hronologiska-seciba?year=2012 [last viewed 09.04.2018].

6. Judgement on Behalf of the Republic of Latvia in case No. 2016-07-01, 8 March 2017, Riga. Available: http://www.satv.tiesa.gov.lv/wp-content/uploads/2016/05/2016-07-01_Spriedums_ENG.pdf [last viewed 05.04.2018].

7. Supreme Court decision case No. C04281907, SKC-284/2017 of December 28, 2017. Unpublished.

8. Case No. SKC-1800/2012. Available: http://at.gov.lv/lv/judikatura/judikaturas-nolemumu-arhivs/ civillietu-departaments/hronologiska-seciba?year=2012 [last viewed 20.04.2018].

9. Case No. SKC248/2017. Available: http://at.gov.lv/lv/judikatura/judikaturas-nolemumu-arhivs/ civillietu-departaments/hronologiska-seciba?year=2017 [last viewed 18.04.2018].

\section{Other Sources}

1. Bērziņšs, G. Atziṇas par aktuālo tiesu praksi maksātnespējas jomā [Conclusions about current court practise in insolvency proceedings]. Jurista Vārds, No. 14(917), 2016. 
2. German Civil Code (BGB), Civil Code in the version promulgated on 2 January 2002 (Federal Law Gazette [Bundesgesetzblatt] I page 42, 2909; 2003 I page 738), last amended by Article 4 para. 5 of the Act of 1 October 2013 (Federal Law Gazette I page 3719). Available: http://www.gesetze-iminternet.de/englisch_bgb/englisch_bgb.html\#p3671 [last viewed 05.04.2018].

3. Corpus Iuris Civilis. Editio stereotypa tertia. Volumen primum. Institutionas. Recognovit. Paulus Krueger. Digesta. Recognovit. Theodorus Mommsen. Berolini. Apud Weidmannos. MDCCCLXXXII.

4. Maksātnespējas administrācijas 2017. gada ziṇojums [Report by Insolvency administration of 2017], p. 23. Available: http://www.mna.gov.lv/faili/pub_84.pdf [last viewed 22.03.2018].

5. Čepāne, I. Kuğis vai māja - tāds ir jautājums [A ship or a building - that is the question]. Jurista Vārds, No. 15(1021), 2018.

6. Pēc "Nekā personīga" sižeta "Swedbank" atsakās no hipotēkas mājai, ko īpašniekam izkrāpa organizēta grupa [After a TV broadcast "Nothing personal", "Swedbank" refuses from a mortgage put on the house which was defrauded from its owner by an organised criminal group]. Available: https://skaties.lv/zinas/latvija/neka-personiga/pec-neka-personiga-sizeta-swedbank-atsakas-nohipotekas-majai-ko-ipasniekam-izkrapa-organizeta-g [last viewed 11.04.2018].

7. Pētījums par Civillikuma lietu tiesību daļas pirmās, otrās un trešās dạ̧as modernizācijas nepieciešamibu [Research on necessity to update Chapters I, II and III of Property Law Section of the Civil Law], 2008. Available: https://www.tm.gov.lv/lv/nozares-politika/petijumi [last viewed 24.04.2018].

8. Real Property Law and Procedure in the European Union. General Report. Final Version. European University Institute (EUI) Florence/European Private Law Forum Deutsches Notarinstitut (DNotI). Würzburg, p. 17. Available: https://www.eui.eu/Documents/DepartmentsCentres/Law/ ResearchTeaching/ResearchThemes/EuropeanPrivateLaw/RealPropertyProject/GeneralReport.pdf [last viewed 17.06.2019].

9. Svod Grazhdanskih Uzakonenij Gubernij Pribaltijskih. Izdanie 1864 goda, so vkljucheniem statej po Prodolzheniju 1890 goda [Codification of Civil law of the Baltic region. Edition of 1864, with amendments until 1890]. S.-Peterburg: Izdanie kodifikacionnogo otdela pri gosudarstvennom sovete, [s. a.]. Available: https://dspace.lu.lv/dspace/handle/7/1209?locale-attribute=ru [last viewed 21.03.2018].

10. The Digest Justinian. Translation edited by A. Watson. Vol. 2. Philadelphia: Pennsylvania University of Pennsylvania Press, 1998.

11. Virko, E. Zemesgrāmatu pieejamiba un ticamïba (I) [Availability and credibility of land registers]. Jurista Vārds, No. 13(518), 2008.

12. Virko, E. Zemesgrāmatu pieejamība un ticamība (II) [Availability and credibility of land registers]. Jurista Vārds, No. 15(520), 2008. 


\title{
Origins of Separated Ownership and Possible Solutions for Unifying Thereof
}

\author{
Dr. iur. Kaspars Balodis \\ University of Latvia, Faculty of Law, Professor at the Department of Civil Law \\ E-mail: kaspars.balodis@lu.lv \\ LL.M Arta Snipe \\ University of Latvia, Faculty of Law, Doctoral Student \\ E-mail:arta@snipe.lv
}

\begin{abstract}
The article focuses on the issues of separated ownership of properties and compulsory land lease in the cities of the Republic of Latvia. Separation of ownership was a result of land reform, whereby land and buildings on it have different owners. The first part of the article examines the historical circumstances, in which separated ownership of properties and compulsory land lease originated and reveals why the legal relationships between landowners and building owners are regulated as lease agreements. Further on, the article analyses three possible ways (models) of unification of separation ownership of properties. While focusing on analysis of these models, the main unresolved issues concerning collection of land lease payments are outlined. Among these are the legal status of the community of apartment owners and representation of apartment owners in court proceedings.
\end{abstract}

Keywords: separated ownership, restitution, compulsory land lease, unification of ownership, a buyout, community of apartment owners, property right, restriction on property right, land reform.

\section{Contents}

Introduction . . . . . . . . . . . . . . . . . . . . . . . . . . . . . . . . 140

1. Origins of Separated Ownership of Land and Buildings Thereon . . . . . . . . . . . 141

1.1. Historical Circumstances That Created Separated Ownership . . . . . . . . . . 141

1.2. Current Situation Concerning Properties with Separated Ownership . . . . . . . 143

2. The Possible Models for Unifying Separated Ownership . . . . . . . . . . . . . . . . 145

2.1. Unification of Ownership on the Basis of Special Law by Decision

of Community of Apartment Owners (Model 1) . . . . . . . . . . . . 146

2.1.1. Apartment Owners' Obligation to Buy Out the Land . . . . . . . . . . . 146

2.1.2. Contesting the Decision of Community of Apartment Owners . . . . . . . 147

2.2. Voluntary Buyout of Undivided Share of Land Plot (Model 2) . . . . . . . . . . 149

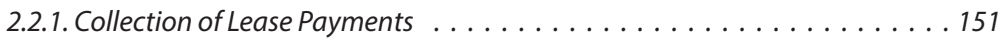

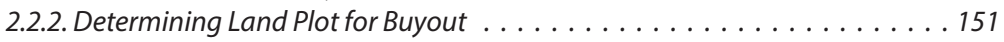

2.2.3. Registration of Title to Property in Land Register . . . . . . . . . . . . . 152

2.3. Expropriation of Land Property to Transfer It for Privatisation (Model 3) . . . . . 153 
2.3.1. Financing Required to Implement the Model . . . . . . . . . . . . . 153

2.3.2. Violation of Article 105 of the Satversme . . . . . . . . . . . . . . . . . . 154

3. The Amount of Land Lease Fee and Lease Collection During Buyout Process . . . . . . 155

Summary. . . . . . . . . . . . . . . . . . . . . . . . . . . . . . . . . . . . 157

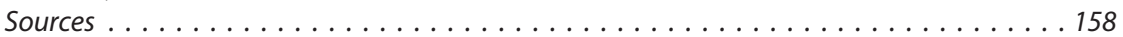

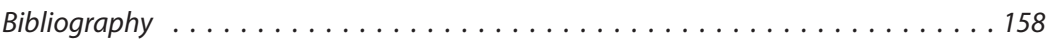

Normative Acts . . . . . . . . . . . . . . . . . . . . . . . . . . . . . . . 159

Travaux Preparatoires .............................. 160

Case Law ........................................ 160

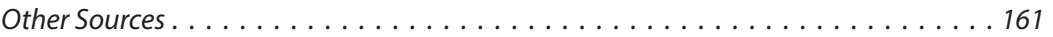

\section{Introduction}

The continuity of the State of Latvia is 'the backbone' of Latvia's constitutionalism. ${ }^{1}$ After the restoration of independence, one of the most significant symbolic steps to demonstrate the legal continuity of the State to the international community, was restitution, i.e., restoration of the title to the immovable property, which the owners had been deprived of during the years of Soviet occupation. ${ }^{2}$ Restoration of the private land ownership and denationalisation of nationalised properties was an indispensable part of the transitional period in many countries of Central and Eastern Europe. At least partial restoration of the previous status in order to ensure justice following the collapse of the Soviet order was perceived as being self-evident. ${ }^{3}$

The Supreme Council of the Republic of Latvia could choose the form and the scope of restitution - either to return the original property or to use various other forms of compensation, as was done, for example, by Hungary. ${ }^{4}$ Latvia decided to return original properties, or to compensate their value by government certificates in those cases, where it was impossible to return the property or a person entitled did not want to regain it. ${ }^{5}$ The preference was given to the return of original property. This symbolically demonstrated the continuity of the state and, at least partial, restoration of the legal status of 1940. The 'creation of owners' was the essential basis to ensure the transition to the market economy, restore the significance and value of private property and private economic initiative. ${ }^{6}$

1 Endzinšs, A. Latvijas konstitūcijas apskats, kas rada šaubas un jautājumus [Overview of the Latvian Constitution, which Causes Doubts and Questions]. Jurista Vārds, No. 8(363), 2005, p. 4.

2 Feldman, M. Justice in space? The restitution of property rights in Tallinn, Estonia. Ecumene, No. 6(2), April 1999. Available: https://www.jstor.org/stable/44252046 [last viewed 24.09.2018], p. 168.

3 Blacksell, M., Born, K. M. Private Property Restitution: The Geographical Consequences of Official Government Policies in Central and Eastern Europe. The Geographical Journal, No. 168(2), June, 2002. Available: https://www.jstor.org/stable/3451616 [last viewed 24.09.2018], pp. 178-179.

4 Pogany, I. Righting wrongs in Eastern Europe. Manchester, New York: Manchester University Press, 1997, pp. 162-163.

5 Par valsts ìpašumu un tā konversijas pamatprincipiem [On State Property and the Principles of Conversion thereof].Ziņotājs, No. 19/20, 23.05.1991, Diena, No. 69, 11.04.1991, para. 3) of section 5; Par zemes reformu Latvijas Republikas pilsētās [On Land Reform in Cities of the Republic of Latvia]. Zinotājs, No. 49/50, 19.12.1991, Diena, No. 242, 13.12.1991, the first part of section 12 in the wording that was in force until 14.11.1995.

6 Grūtups, A., Krastiňš, E. İpašuma reforma Latvijā [Property Reform in Latvia]. Riga: Mans İpašums, 1995, p. 8; Par valsts īpašumu un tā konversijas pamatprincipiem [On State Property and the Principles of Conversion thereof]. Ziņotājs, No. 19/20, 23.05.1991, Diena, No. 69, 11.04.1991, Preamble. 


\section{Origins of Separated Ownership of Land and Buildings Thereon}

\subsection{Historical Circumstances That Created Separated Ownership}

The principles of restitution were established in the law "On Land Reform in the Cities of the Republic of Latvia", which provided for the former landowners and their heirs the right to demand restoration of the property rights to the land plots previously in their ownership. Only exceptions were the cases, where the former landowners, after 22 July 1940, had alienated their property or if citizens of the Republic of Latvia had built their residential houses on these land plots. In all other cases landowners were given a choice: to demand restoration of the property rights and receive a lease payment from the owner of the building, or to demand an equivalent land plot, or to receive compensation. ${ }^{7}$ Since it was difficult to allocate an equivalent land plot within city boundaries but the compensation matters were uncertain as to amount and means (coverage of certificates was dubious), the majority of the former owners chose to receive original property, even if buildings had been constructed on the land. ${ }^{8}$

Contrary to Latvia, neither Lithuania nor Estonia restored the property rights of the former owners to the land on which constructions owned by third persons were located; the State retained this land in its ownership and allowed the owners of the buildings to use and to buy it out. ${ }^{9}$ This led to the establishment of characteristics of the dualistic system of ownership, which is an exception to the system of divided ownership stipulated in the Civil Law. ${ }^{10}$ Thus, the law allowed the existence of two ownership rights, existing alongside each other, with respect to the same spatially delimited object; this is a legal solution unknown to any other legal system in Europe. ${ }^{11}$

In Latvian law this phenomenon is called dalitie ipašumi. This term has been translated into English by mass media and some articles as 'divided properties', although this literal translation is confusing. However, in the legal sense the term dalitie ipašumi means separated ownership of a property. Legally, the inseparable parts of a property that should be legally united (have one owner) according to the superficies solo cedit presumption, namely, buildings and the land, have different owners in case of separated ownership.

In 2015, there were 285849 buildings and constructions (not including engineering constructions) in Latvia located on, in total, 95254 land plots,

7 Par zemes reformu Latvijas Republikas pilsētās [On Land Reform in Cities of the Republic of Latvia]. Ziñotājs, No. 49/50, 19.12.1991, Diena, No. 242, 13.12.1991, the second part of section 12 in the wording that was in force until 14.11.1995.

8 Grūtups, A., Krastinšs, E. İpašuma reforma Latvijā [Property Reform in Latvia]. Rīga: Mans Īpašums, 1995, p. 10.

9 Piliečių Nuosavybès Teisių I Išlikusį Nekilnojamąji Turtą Atkūrimo İstatymas [On Restitution of Citizens' Title to Property on Existing Immovable Property]. Available: https://e-seimas.lrs.lt/ portal/legalActPrint/lt?ffwid=5sjolg0fi\&documentId=TAIS.364111\&category=TAD [last viewed 25.09.2018], section 12; Maareformi seadus [Land Reform Act]. RT, 1991, 34, 426. Available: https://www.riigiteataja.ee/en/eli/529062016001/consolide [last viewed 25.09.2018], section 7.

10 Rozenfelds, J. Superficies solo cedit Latvijas tiesībās [Superficies solo cedit in the Latvian Law]. Latvijas Universitātes žurnāls. Juridiskā zinātne, Vol. 3. Rỉga: Latvijas Universitāte, 2012, pp. 108-110.

11 Rozenfelds, J. Pētījums par Civillikuma Lietu tiesību daļas (ceturtās, piektās, sestās un septītās nodaḷas) modernizācijas nepieciešamìbu [Study of the Need to Modernise the Part on Rights in Rem, Chapter Four, Five, Six and Seven]. 2008. Available: http://www.tm.gov.lv/files/ archieve/lv_documents_petijumi_cl_ceturta_piekta_sesta_un_septita_nodala.doc [last viewed 30.09.2018], p. 5 . 
owned by other persons. ${ }^{12}$ Among these were 3677 apartment buildings (and 110970 apartments therein), located on 7354 land units owned by other persons. ${ }^{13}$ These numbers show that the issues of divided property affect a considerable number of Latvia's residents.

Drafting the law "On Land Reform in Cities of the Republic of Latvia" in 1991, the legislature decided to regulate the legal relationships between the landowners and the building owners as lease agreements, providing for the landowner's right to receive a lease payment as a compensation from the user of the land. This decision derived from the historical and legal circumstances. In 1991, pursuant to article 6 of Declaration of 4 May "On Restoration of the Independence of the Republic of Latvia", the civil law relationships within the territory of Latvia were regulated by the norms of the Civil Code of the Latvian Soviet Socialist Republic, insofar these were not incompatible with articles 1, 2, 3 and article 6 of the Satversme [the Constitution] of the Republic of Latvia. ${ }^{14}$ The aforementioned Civil Code did not recognise the ownership rights of individuals to land. ${ }^{15}$ Neither did it recognise the concept of superficies solo cedit, nor did it provide for a right in the property of another (ius in re aliena), which is manifested in such institutions of the rights in rem as the servitude, inheritable lease or superficies, which, by retaining a united ownership, creates a restriction on ownership in favour of another person's rights. ${ }^{16}$ The Supreme Council adopted the law "On the Civil Law of the Republic of Latvia of 1937" on 14 January $1992^{17}$, by which it was decided to reinstate the Civil Law, determining, by special laws, the time and the procedure for separate chapters of the Civil Law to re-enter into force. The chapter on rights in rem of the Civil Law entered into force on 1 September 1991, i.e., almost a year after the law "On Land Reform in Cities of the Republic of Latvia", and only at this point the legislation on servitude was restored. ${ }^{18}$ It follows from the above that the legislature's choice in favour of the compulsory land lease was the most appropriate in the specific legal conditions, since at the time of drafting and adopting the laws that regulated land reform no other suitable regulation for the legal relationships between landowners and building owners was available. Thus, at that point the legislature even did not

12 Latvijas Republikas Tieslietu ministrija. Dalitais ippašums [The Ministry of Justice of the Republic of Latvia. Divided Property], 2015. Available: http://onecrm.lv/lps/meetingsearch/displaydocument. aspx?committeename $=$ Tehnisko\%20 probl\%BAmu\%20komiteja\&itemid $=24635919229989771030$ \& meetingid $=1602005 \mathrm{~K} \% 20 \% 20 \% 20 \% 20 \% 20 \% 20 \% 20 \&$ filename=Dal\%EFtais $\% 20 \%$ EFpa\%B9ums. pdf\&cc=Document [last viewed 24.01.2017].

13 Valsts zemes dienests. Nekustamā īpašuma tirgus pārskats [The State Land Service. Overview of the Immovable Property Market]. Available: http://kadastralavertiba.lv/wp-content/uploads/2018/05/ Parskats_15052015_gala.pdf [last viewed 15.06.2018], p. 5.

14 Par Latvijas Republikas neatkaribas atjaunošanu [On Restoration of the Independence of the Republic of Latvia]. Ziñotājs, No. 20, 17.05.1990, section 6.

15 Vēbers, J. (ed.). Latvijas PSR Civilkodeksa komentāri [Commentaries on the Civil Code of the Latvian SSR]. Rīga: Liesma, 1979, p. 141.

16 Rozenfelds, J. Superficies solo cedit Latvijas tiesibās [Superficies solo cedit in the Latvian Law]. Latvijas Universitātes žurnāls. Juridiskā zinātne, Vol. 3. Rìga: Latvijas Universitāte, 2012, p. 109.

17 Par Latvijas Republikas 1937. gada Civillikumu [On the Civil Law of the Republic of Latvia of 1937]. Ziņotājs, No. 4/5, 30.01.1992.

18 Par atjaunotā Latvijas Republikas 1937. gada Civillikuma ievada, mantojuma tiesību un lietu tiesību daḷas spēkā stāšanās laiku un kārtību [On the Date and Procedure for Entering into Force of the Introduction, Part on Inheritance Rights and Rights in Rem]. Ziņotājs, No. 29, 30.07.1992, Diena, No. 135, 24.07.1992. 
have a choice as to whether the civil law relationship between the landowner and the building owner would be regulated as servitude or as compulsory land lease. ${ }^{19}$

On 7 July 1992, the law determining the time and procedure for the coming into force of the chapter of the Civil Law on the rights in rem was adopted. This law provided for a significant exemption to the general presumption of supercifies solo cedit, included in section 968 of the Civil Law, in order to legalise the already established situation of separated ownership. ${ }^{20}$ Although it was theoretically possible at that time, the legal provisions that were included in land reform laws were not amended, failing to use the opportunity to create a system compatible with the Civil Law, replacing the compulsory land lease by, for instance, the servitude. It must be noted that the regulation, which established the servitude rights, was later adopted with respect to the lands of free ports. ${ }^{21}$ However, with regard to the separated ownership of properties in the cities of the Republic of Latvia, the legislature reinforced the aspects of dualistic system of property, and continued applying the concept of 'lease' to the quasi-contractual legal relationship, although the latter lacked the element of the parties' will integral for contracts and whose coercive nature suggests it being more like an encumberment of ownership. ${ }^{22}$ The only right left to the landowner is the right to demand the payment of land lease, retaining both the obligation to pay the immovable property tax and to upkeep the property, and to assume both civil and administrative responsibility for it.

\subsection{Current Situation Concerning Properties with Separated Ownership}

In the transitional period, the legislature's choice was appropriate for the legal situation and the political aims of the time. At the time, when the separated ownership and compulsory land lease relationships originated, it was impossible to forecast the problems of legal, economic and social nature that these solutions might cause. The legislature chose, in its opinion, the most appropriate solution to balance the lawful interests of the former landowners with the lawful interests of the owners of buildings. ${ }^{23}$

19 Judgement of 13 February 2009 by the Constitutional Court of the Republic of Latvia in case No. 2008-34-01. Latvijas Vēstnesis, No. 27(4013), 2009. Available: http://www.satv.tiesa.gov.lv/web/ viewer.html?file=/wp-content/uploads/2008/07/2008-34-01_Spriedums_ENG.pdf [last viewed 15.06.2019], para. 23.1.

20 Par atjaunotā Latvijas Republikas 1937. gada Civillikuma ievada, mantojuma tiesību un lietu tiesību dal̦as spēkā stāšanās laiku un kārtību [On the Date and Procedure for Entering into Force of the Introduction, Part on Inheritance Rights and Rights in Rem]. Zinotäjs, No. 29, 30.07.1992, Diena, No. 135, 24.07.1992, section 14.

21 Rìgas brīvostas likums [The Free Port of Riga Law]. Latvijas Vēstnesis, No. 111/112(2022/2023), 28.03.2000, Ziñotājs, No. 8, 20.04.2000. Available: https://likumi.lv/ta/en/en/id/3435-the-free-portof-riga-law [last viewed 15.06.2019], section 4; Ventspils brivostas likums [The Free Port of Ventspils Law], Latvijas Vēstnesis, No. 1/2(716/717), 03.01.1997, Zin̨otājs, No. 3, 13.02.1997. Available: https:// likumi.lv/ta/en/en/id/41737-the-free-port-of-ventspils-law [last viewed 15.06.2019], section 4 .

22 Compare, see Rozenfelds, J. Pētījums par Civillikuma Lietu tiesību dą̣as (ceturtās, piektās, sestās un septītās nodaḷas) modernizācijas nepieciešamību [Study of the Need to Modernise the Part on Rights in Rem, Chapter Four, Five, Six and Seven], 2008. Available: http://www.tm.gov.lv/files/ archieve/lv_documents_petijumi_cl_ceturta_piekta_sesta_un_septita_nodala.doc [last viewed 30.09.2018], pp. 5-6.

23 See Judgement of 13 February 2009 by the Constitutional Court of the Republic of Latvia in case No. 2008-34-01. Latvijas Vēstnesis, No. 27(4013), 2009. Available: http://www.satv.tiesa.gov.lv/web/ viewer.html?file=/wp-content/uploads/2008/07/2008-34-01_Spriedums_ENG.pdf [last viewed 15.06.2019], paras. 4, 24 . 
Restoring the ownership rights also to the lands that were encumbered by apartment buildings meant restitution of the historical justice with respect to the lawful owners of land and their heirs. Today, it is often forgotten that during the years of Soviet occupation many citizens of Latvia were evicted from their family homes in the cities and large apartment buildings were constructed in their stead to house the migrants that were flown in from the republics of the USSR. On the other hand, it turned out that separated ownership on a property was probably not successful means to promote a market economy. The mass media reports and also observations of the legal proceedings regarding collection of the land lease show that the apartment owners do not always understand why the land had not been transferred into their property free of charge and are reluctant to accept the statutory obligation to pay the land lease to landowners. ${ }^{24}$ However, it must be noted that the amount of land lease fee for apartment owners may differ significantly since it depends on the area of the land plot necessary for the apartment building and also on the location of the property. The landowners, in turn, are restricted by the obligation set in the law to 'conclude a lease agreement', which is a pre-condition for collecting the land lease through the court.

Although the deficiencies of the separated ownership and compulsory land lease sometimes are exaggerated not only in media but even in expert discussions, undeniably, due to legal policy, social and economic considerations, legislator could do far more to support and stimulate the unification of ownership. In the consideration of the above mentioned, both the executive power and the legislature have expressed the opinion that the preferable long-term solution would be the unification of ownership in properties with separated ownership. ${ }^{25}$ The aim is to reach a point where the buildings and the land upon which they are erected have the same owners. The involved parties understand that this is a complex and perplexing process, which is proven by the prolonged work of the working groups established by the Ministry of Justice and by already the second draft law submitted to the Saeima [the Parliament] to unify the ownership. ${ }^{26}$ However, the recognised directions and aims of legal policy are to be taken into consideration in lawmaking process, as well as facts, background and possible impact of the policy on the involved parties. The circumstances that foster or, quite to the contrary, have a negative impact on the interest of the involved persons in unifying the ownership must particularly be taken into consideration. Moreover, the legislature may not choose a solution for unifying the ownership in properties and compulsory land lease relationship that violate the rights to property of the involved parties that are provided for in article 105 of the Satversme (the Constitution of the Republic of Latvia).

24 Dzedulis, Z. Zemes nomas k̦īlnieki [Hostages of Land Lease]. Latvijas Avizze, 17.08.2018. Available: http://www.la.lv/zemes-nomas-kilnieki [last viewed 20.10.2018].

25 Grozijums Ministru kabineta 2010. gada 13. septembra rỉkojumā Nr. 541 "Par Koncepciju par Civillikuma lietu tiesību daļas modernizāciju" [Amendment to the Cabinet Order of 13 September 2010 No. 541 "On the Concept Paper on Modernising the Part on Rights in Rem of the Civil Law]. Latvijas Vestnesis, No. 94(4697), 15.02.2012; Transcript of the Sitting of the $12^{\text {th }}$ Saeima of the Republic of Latvia on 17 March 2016. Available: http://titania.saeima.lv/LIVS12/saeimalivs12. nsf/0/FAF4C0D35BA5CCE9C2257F8C0023E471 [last viewed 16.08.2018].

26 Latvijas Republikas Tieslietu ministrija. Dalitais ippašums [The Ministry of Justice of the Republic of Latvia. Separated ownership]. 2015. Available: http://onecrm.lv/lps/meetingsearch/ displaydocument.aspx? committeename $=$ Tehnisko\%20probl\%BAmu\%20komiteja\&itemid $=24635$ 919229989771030\&meetingid $=1602005 \mathrm{~K} \% 20 \% 20 \% 20 \% 20 \% 20 \% 20 \% 20 \&$ filename=Dal\%EFtais\% 20\%EFpa\%B9ums.pdf\&cc=Document [last viewed 24.01.2017]. 


\section{The Possible Models for Unifying Separated Ownership}

On 12 April 2018, the Constitutional Court of the Republic of Latvia delivered judgement in case No. 2017-17-01, repeatedly ruling on the constitutionality of the decrease in the amount of the compulsory land lease fee. ${ }^{27}$ The decrease in the amount of the lease fee, set by the Saeima, from $6 \%$ of the cadastral value of the land annually provided in the law until 2017, to not more than 5\% in 2018, not more than 4\% in 2019 and not more than 3\% in 2020 was contested before the Constitutional Court. The Constitutional Court recognised the respective norms as being incompatible with the Satversme and void as of 1 May 2019.

At the press conference, which was held after pronouncing the judgement, the President of the Constitutional Court Ineta Ziemele underscored that, by leaving the norms that were incompatible with the Satversme in force, the Constitutional Court had decided to not create additional tension in society. Following the principle of justice, the Constitutional Court had given time to the legislature for finding a solution to the particular situation, in the procedure of developing which the possible restrictions of persons' fundamental rights would be duly assessed and in which the rights of landowners and the owners of apartment buildings would be duly balanced. ${ }^{28}$

Following the pronouncement of the judgement, the legislature has focused their attention to the drafting of a legal framework to unify the separated ownership. Whereas until the beginning of 2019, just few months before the norms that were contested in case No. 2017-17-01 will become void, the enforcement of the Constitutional Court's judgement and setting the amount of the lease fee that would comply with the Satversme, remains unaddressed. ${ }^{29}$

Upon selecting public policy instruments, it is of utmost importance to start with defining the aim to be attained: is it the complete unification of ownership in all the properties by imposing the obligation on both parties, accordingly, to sell or to buy out the land, or should only the procedure be adopted how to unify the ownership when there is a mutual consent of the parties, or should the new regulation impose an obligation on apartment owners to buy out the land, if the landowner wishes to sell it. There are several possible models for unification of ownership of the buildings and the lands, and with respect to each of them it must be assessed, how complex it is to commence this process, what is the amount of the related costs and who covers these, and how the fundamental rights of the involved persons are to be protected. In each of the possible models, it is essential to follow

27 Judgement of 12 April 2018 by the Constitutional Court of the Republic of Latvia in the case No. 2017-17-01. Latvijas Vēstnesis, No. 74(6160), 2018. Available in English: http://www.satv. tiesa.gov.lv/en/press-release/the-norms-which-as-of-1-january-2018-decrease-the-amount-ofcompulsory-land-lease-are-incompatible-with-the-satversme/ [last viewed 15.06.2019].

28 The Constitutional Court of the Republic of Latvia. 12.04.2018. Press Conference on the Judgement in case No. 2017-17-01. Available: https://www.youtube.com/watch?v=x3MMD9962NI [last viewed 14.05.2018].

29 See Ministru kabineta atbilde Nr. 18/TA-2000. Par Latvijas pilsoņu kolektīvo iesniegumu "Zemei zem daudzdzīvokḷu mājām jābūt tikai šo māju iedzīvotāju īpašumā” [The Cabinet of Ministers. Reply No. 18/TA-2000. On the collective application by the citizens of Latvia "The land beneath multiapartment buildings should be owned only by the owners of these buildings"]. Available: http:// tap.mk.gov.lv/doc/2018_10/TMVest_221018_Dalita_izbeigsa.2000.docx [last viewed 19.11.2018]; Transcript of the Sitting of the $12^{\text {th }}$ Saeima of the Republic of Latvia on 17 March 2016. Available: http://titania.saeima.lv/LIVS12/saeimalivs12.nsf/0/FAF4C0D35BA5CCE9C2257F8C0023E471 [last viewed 16.08.2018]. 
the united policy that is oriented towards unification of ownership using tools that motivate both landowners and apartment owners.

\subsection{Unification of Ownership on the Basis of Special Law by Decision of Community of Apartment Owners (Model 1)}

The purpose of the draft law "Law on Terminating the Enforced Separated Ownership in the Privatised Multi-apartment Buildings" (No. 1211/Lp12; 115/ Lp13) prepared by the Public Administration and Local Government Committee of the Saeima of the Republic of Latvia is to ensure that the whole land plot that is functionally necessary for the building is bought out. ${ }^{30}$ Although the draft law (in Latvian) uses the term 'redemption rights', it must be stressed that this term is not related to the redemption rights regulated in section 1381 and the following sections of the Civil Law.

If this model is implemented, then the community of apartment owners will have to take a decision on buying the land, i.e., the apartment owners, who, numerically, own more than a half of the apartment properties in the building, must vote on commencing the procedure for exercising the buyout rights. ${ }^{31}$ Although, if the buyout is successfully exercised, the ownership on the property would be united (the land and the building will have the same owners or joint-owners), the procedure in general is so cumbersome that serious doubts arise, whether it would be feasible in a building consisting of more than just a couple of apartments. ${ }^{32} \mathrm{~A}$ successful course of the procedure requires a decision by the community of apartment owners on commencing the buyout procedure, an effective meeting of apartment owners, as well as payment of full purchase price.

\subsubsection{Apartment Owners' Obligation to Buy Out the Land}

Substantially, the draft law No. 155/Lp13 sets not only the landowners' obligation to sell the land (section 4 of the draft law) but also imposes the obligation to participate in the buyout of the land on those apartment owners (the minority), who have voted against commencing the buyout procedure. Moreover, payment of the total buyout price is the pre-requisite for exercising this right. Consequently, it follows that someone else has to pay the purchase price instead of those apartment owners, who do not want or are unable to buy out the land, acquiring the right to claim recourse from the respective apartment owners. Otherwise, the buyout rights are recognised as not having been exercised and all activities conducted in

30 Likumprojekts "Piespiedu dalītā īpašuma privatizētajās daudzdzīvokḷu mājās izbeigšanas likums" [Draft law "Law on Terminating the Enforced Separated Ownership in the Privatised Multiapartment Buildings"]. Available: http://titania.saeima.lv/LIVS12/saeimalivs12.nsf/webSasaiste? OpenView\&restricttocategory=1211/Lp12 [last viewed 30.10.2018].

31 Dż̄vokḷa īpašuma likums [Law On Residential Properties]. Latvijas Vēstnesis, No. 183(4375), 17.11.2010. Available: https://likumi.lv/ta/en/en/id/221382-law-on-residential-properties [last viewed 15.06.2019], sections 5, 16(3); Likumprojekts "Piespiedu dalītā īpašuma privatizētajās daudzdzīvokḷu mājās izbeigšanas likums" [Draft law "Law on Terminating the Enforced Separated Ownership in the Privatised Multi-apartment Buildings"]. Available: http://titania.saeima.lv/ LIVS12/saeimalivs12.nsf/webSasaiste?OpenView\&restricttocategory=1211/Lp12 [last viewed 30.10.2018], section 5 .

32 Latvijas Republikas Saeimas Juridiskais birojs. Atzinums par likumprojektu "Piespiedu dalìtā īpašuma privatizētajās daudzdzìvokḷu mājās izbeigšanas likums" [Legal Bureau of the Saeima of the Republic of Latvia. Opinion on the draft law "Law on Terminating the Enforced Separated Ownership in Privatised Multi-apartment Buildings]. Available: http://titania.saeima.lv/LIVS12/ saeimalivs12.nsf/0/1036916E0888874EC2258294002A933D [last viewed 21.10.2018]. 
the framework of the procedure, except only determination or reviewing of the functionally necessary land plot, would have been conducted in vain. ${ }^{33}$

When analysing the proposed legislative approach of Model 1, it is important to recognise that it would impose the obligation to participate in the buyout of the land on those apartment owners, who do not want it. This obligation should be evaluated from the perspective of article 105 of the Satversme (enshrines the protection of property). There would be no violation of the right to property, provided for in article 105 of the Satversme, if the apartment owner, who would be forced, against his will, to participate in the buyout of the land, would not be imposed an obligation to make payments that exceed the lease fee paid thus far. If the buyout payments would exceed the current lease fee, the proportionality of the obligation to buy out the land could be contested. ${ }^{34}$

It can be concluded that the legislature's attempts to lower the lease fee, as it was done by adopting the amendments of 22 June 2017 to section 12 of the law "On Land Reform in Cities of the Republic of Latvia" and the amendments of 1 June 2017 to section 54 of the law "On Privatisation of State and Local Government Residential Houses", do not facilitate reaching of the legislature's aim, i.e., a buyout of the land. If significant restrictions on the amount of the lease fee are set in law, there is a risk that the fundamental rights of those apartment owners, who do not agree to the community's decision to buy out the land, will be infringed upon. Namely, these apartment owners, possibly, will have to make larger payments for buyout compared to the lease fee defined in law. Moreover, the amount of lease fee defined in law will not serve as an incentive for apartment owners to buy out the land.

\subsubsection{Contesting the Decision of Community of Apartment Owners}

If the community of apartment owners decides to buy out the land then those apartment owners, who have voted against the buyout procedure, will have the right to contest the community's decision in a court. This right follows from section 16(4) of the law "On Residential Properties", which provides that the community's decision may be contested if the decision or the procedure for taking thereof are in contradiction with the provisions of this law.

The community of apartment owners is the administrative body of a residential house which is partitioned into apartment properties (apartment building). The composition of the community of apartment owners shall include all apartment owners of the building. A decision of the community of apartment owners is binding for all apartment owners, if the apartment owners who represent the respective share (usually - more than a half) of the apartment properties in the building, have voted in favour of the respective decision.

Bringing of a claim against a community of apartment owners is encumbered by the fact that it is not an independent legal or natural person, and thus has not been vested with the capacity of being a party to court proceedings. Thus, although the law provides that the claim should be brought 'against the community', it cannot

33 Latvijas Republikas Saeimas Juridiskais birojs. Atzinums par likumprojektu "Piespiedu dalìtā īpašuma privatizētajās daudzdzìvokḷu mājās izbeigšanas likums" [Legal Bureau of the Saeima of the Republic of Latvia. Opinion on the draft law "Law on Terminating the Enforced Separated Ownership in Privatised Multi-apartment Buildings]. Available: http://titania.saeima.lv/LIVS12/ saeimalivs12.nsf/0/1036916E0888874EC2258294002A933D [last viewed 21.10.2018].

34 Compare, see Balodis, K. Komentārs pie Satversmes 105. panta [Commentary on Article 105 of the Satversme]. In: Latvijas Republikas Satversmes komentāri. VIII nodaḷa. Cilvēka pamattiesïbas. Riga: Latvijas Vēstnesis, 2011, theses 25, 32, 33. 
be a party in the court proceedings. Pursuant to the legal definition included in the law "On Residential Properties", the community consists of all apartment owners, therefore the claim against the community should be brought as a claim against all joint owners of the building. In the case law, this norm is interpreted to mean that the claim regarding recognition of the decision as void can be brought only by an apartment owner (and not, for example, by the building manager) and it should be brought against all those apartment owners, who have adopted this decision. ${ }^{35}$

Lawyers have criticised the concept of the community of apartment owners regarding the capacity to be a party to court proceedings of the community, pointing to the procedural deficiencies that are linked to summoning a large number of defendants to the court. ${ }^{36}$ Legal proceedings, involving a large number of joint owners, are not only costly but also lengthy or, actually, even impossible. If the buyout rights are exercised, it means that in the case the dispute is brought to court, the statutory deadlines cannot be met. Contesting the decision of the community of apartment owners automatically means that it will be impossible to exercise the buyout rights in the particular building.

A community of apartment owners can neither assume obligations nor acquire rights. A community of apartment owners is an unincorporated institution - an association in accordance with the regulation of section 2241 to 2261 of the Civil Law lacking legal capacity. The law provides for an exemption with regard to the landowners who has the right to bring a claim regarding conclusion of a lease agreement against one defendant - the manager, which represents the interests of all the apartment owners in the court. However, in those cases, where the decision or action of the community of apartment owners is contested, there is no legal provision facilitating legal proceedings and ensuring the procedural economy. ${ }^{37}$ The Constitutional Court has stressed that the State has the obligation to create such legal system and establish such procedure that would allow a person to effectively defend his rights and lawful interests. ${ }^{38}$ To ensure resolution of the cases involving a community of apartment owners, the legislature should consider and introduce a solution, pursuant to which a community of apartment owners could have a capacity to be the plaintiff and the defendant in a court. The respective legal provision should be included in section 15 of the law "On Residential Properties", which defines the status of the community of apartment owners.

At the same time, the person, who may represent the community of apartment owners, should be defined in the law. From the perspective of the right to a fair trial, provided for in article 92 of the Satversme, it is essential to define one person responsible for performing the managerial activities for the building. This person

35 Judgement of 7 October 2015 by the Department of Civil Cases of the Supreme Court of the Republic of Latvia in case No. SKC-201/2015. Available: https://manas.tiesas.lv/eTiesasMvc/nolemumi/ pdf/235206.pdf [last viewed 31.10.2018]; Judgement of 30 May 2014 by the Department of Civil Cases of the Supreme Court of the Republic of Latvia in case No. SKC-1208/2014. Available: https:// manas.tiesas.lv/eTiesasMvc/nolemumi/pdf/161961.pdf [last viewed 22.10.2018], para. 8.3.

36 Diskusijas un jautājumi Civiltiesību sekcijā [Discussions and Questions in the Civil Law Section]. Latvijas Republikas Augstākās tiesas biḷetens, No. 3, December 2011, p. 23.

37 Compare with "Par valsts un pašvaldību dzīvojamo māju privatizāciju” [On Privatisation of State and Local Government Residential Houses]. Ziņotājs, No. 49/50, 19.12.1991, Diena, No. 242, 13.12.1991, section 54(2).

38 Judgement of 9 January 2014 by the Constitutional Court of the Republic of Latvia in case No. 2013-08-01. Latvijas Vēstnesis, No. 8(5067). Available: http://www.satv.tiesa.gov.lv/web/ viewer.html?file=/wp-content/uploads/2013/04/2013-08-01_Spriedums_ENG.pdf [last viewed 15.06.2019], para. 13 . 
could be also the plaintiff and the defendant in a court, representing the numerous and changing community of apartment owners in any legal relationship. This person should have the right to represent the community, to assume obligations and to exercise rights on behalf of the community. ${ }^{39}$

The law should provide that the manager should be recognised as the community's representative, unless the community itself has decided otherwise and has appointed another representative. For comparison, it is defined in the Law on Collective Management of Copyright that the collective management organisation is entitled to represent even those holders of copyright and related rights who have not entered into a collective management agreement. ${ }^{40}$

In summary, it can be concluded that the procedure for unifying the separated ownership, provided for in the draft law "Law on Terminating the Enforced Separated Ownership in the Privatised Multi-apartment Buildings", in its general outline, is appropriate. However, the requirement to have a coordinated decision by the community of apartment owners and the right of each apartment owner to contest this decision makes it cumbersome and hard to implement. It is highly probable that only a small share of owners of residential buildings will exercise the buyout rights in accordance with this law.

\subsection{Voluntary Buyout of Undivided Share of Land Plot (Model 2)}

To establish the procedure for unifying the separated ownership, the draft "Law on Terminating the Enforced Separated Ownership in the Privatised Multiapartment Buildings" uses the approach, which is based on the interpretation of section 1068 of the Civil Law, consolidated in the case law of the Supreme Court until 2016. Section 1068 of the Civil Law contains the prohibition to act with the subject-matter of the joint ownership, either as a whole or with respect to stated individual shares, without the consent of all the joint owners. Until recently it was recognised in the case law that this prohibition contains also the prohibition for one joint owner, without the consent of others, to receive lease fee for the undivided shares of the joint property. ${ }^{41}$ The undivided share in the joint property is understood as the joint owner's rights with respect to the joint property; it is intangible property, it cannot be actually handled, inter alia, consumed. ${ }^{42}$ Pursuant to section 2113 of the Civil Law, the subject-matter of lease may be all such tangible property, the alienation of which is not prohibited, as well as rights that can be transferred separately. In interpreting this legal provision, it was underscored in the

39 AS “Latvenergo" 08.02.2009. atzinums "Par likumprojektu Dzīvojamo māju pārvaldīšanas likums” [Joint Stock Company "Latvenergo". Opinion "On the Draft Law on Management of Residential Buildings”]. Available: http://titania.saeima.lv/LIVS/SaeimaLIVS.nsf/0/d9a4e435aaab22a6c22575 980021038c/\$FILE/1438-Jur.pdf [last viewed 30.10.2018].

40 Autortiesību kolektīvā pārvaldijjuma likums [Law on Collective Management of Copyright]. Latvijas Vēstnesis, No. 106(5933), 31.05.2017. Available: https://likumi.lv/ta/en/en/id/291146-lawon-collective-management-of-copyright [last viewed 15.06.2019], sections 5(3), 3(2).

41 Judgement of 15 September 2010 by the Department of Civil Cases of the Supreme Court of the Republic of Latvia in case No. SKC-174/2010 (C04355106). Unpublished.

42 Judgement of 14 September 2009 by the Department of Civil Cases of the Supreme Court of the Republic of Latvia in case No. PAC-1734/2009 (C01173409). Available: http://www.zemesgramata. lv/likumi/lemumi/pac-1734.doc [last viewed 21.10.2018]. 
doctrine that an undivided share cannot be lent or given for storage, lease or rent, since the actual share of a property or the whole property can only be used. ${ }^{43}$

The arguments provided above often kept landowners from selling the undivided shares to apartment owners because the establishment of joint property of the land property and the landowner entering into the legal relationship of joint property with one or several apartment owners, theoretically, prohibited the landowner from receiving the lease fees from the other apartment owners without the consent of the joint owners.

The Constitutional Court, in examining the application of section 1068 of the Civil Law in cases when the land was jointly owned by a number of persons, recognised: "If [..] the so-called compulsory lease relations have been established, then the owner of the land plot shall have the right to request lease payment established by law proportionally to the undivided share of the land plot owned by him or her disregarding the fact whether a consent of other co-owners has or has not been received in respect to such request". ${ }^{4}$ Following the interpretation of the legal provisions included in the Constitutional Court's judgement, the Supreme Court subsequently changed the case-law and proclaimed that section 1068 of the Civil Law was not an obstacle for satisfying a joint owner's claim regarding collection of the land lease fee proportionally to the undivided shares of the land plot in his ownership. ${ }^{45}$ Whereas in the case of a dispute an individual landowner may bring a claim to establish the amount of the lease fee - this claim does not require the consent of other joint owners and the joint owners are not required to agree on the amount of the fee, i.e., each joint owner, proportionally to his undivided share, may receive lease fee that has been agreed on, voluntarily or via the court, with the user of the land. ${ }^{46}$

Hence, following the findings made by the Constitutional Court in the judgement in case No. 2010-01-01 and the current case law of the Supreme Court, legal obstacles no longer exist for each apartment owner to buy the undivided share of land, where the size of the undivided share is stipulated proportionally to the size of the apartment property. Entering into the joint ownership with any of the apartment owners no longer prohibits the landowner from receiving the lease fee from those apartment owners, who have not bought out the land.

43 Grūtups, A., Kalniņšs, E. Civillikuma komentāri. Trešā daḷa. Lietu tiesības. Īpašums [Commentaries on the Civil Law. Part Three. Rights in Rem. Property]. $2^{\text {nd }}$ enlarged edition. Rìga: Tiesu namu ağentūra, 2002, pp. 267-268; Torgāns, K. (ed.). Latvijas Republikas Civillikuma komentāri. Saistību tiesības [Commentaries on the Civil Law of the Republic of Latvia. Obligations Law]. $2^{\text {nd }}$ edition. Rīga: Mans Īpašums, 2000, pp. 471-472; Torgāns, K. Saistību tiesības. II daḷa [Obligations Law. Part Two]. Rìga: Tiesu namu aǵentūra, 2008, p. 98.

44 Judgement of 25 October 2011 by the Constitutional Court of the Republic of Latvia in case No. 2011-01-01. Latvijas Vēstnesis, No. 171(4569), 2011. Available: http://www.satv.tiesa.gov.lv/ web/viewer.html?file=/wp-content/uploads/2011/01/2011-01-01_Spriedums_ENG.pdf [last viewed 15.06.2019], para. 14.3.2.

45 Judgement of 29 September 2010 by the Senate of the Supreme Court of the Republic of Latvia in case No. SKC-182/2010 (C30234305). Unpublished; Judgement of 30 May 2016 by the Department of Civil Cases of the Supreme Court of the Republic of Latvia in case No. SKC-118/2016. Available: http://31.24.192.35/downloadlawfile/677 [last viewed 14.06.2018]; Judgement of 17 June 2016 by the Department of Civil Cases of the Supreme Court of the Republic of Latvia in case No. SKC-252/2016 (C28135508). Available: https://manas.tiesas.lv/eTiesasMvc/nolemumi/pdf/270517.pdf [last viewed 14.06.2018].

46 Judgement of 23 November 2016 by the Department of Civil Cases of the Supreme Court of the Republic of Latvia in case No. SKC-287/2016 (C20136206). Available: http://31.24.192.35/ downloadlawfile/677 [last viewed 14.06.2018], para. 17.1. 
The decision of the community of apartment owners on commencing the buyout procedure is no longer required to buy the land (or undivided shares of the land) in the aforementioned way; the unwillingness of one or several apartment owners to buy out the land or objective circumstances that prohibit this no longer will be an obstacle to buy the land for those apartment owners who wish to do so.

\subsubsection{Collection of Lease Payments}

Individual apartment owners already now may voluntarily agree with the landowner to buy the undivided shares of the land plot; however, deficiencies in the legal regulation keep them from entering into such agreements. Namely, there are no legal provisions that regulate specifically the landowner's right to receive the land lease fee if partial set-off or partial merge of the creditor and debtor into one person can be established. This applies to those cases, where the apartment owner owns undivided shares of the land property. Although as to the meaning and purpose, the apartment owner, who at the same time is the owner of the appropriate undivided shares of the land plot, should no longer pay the land lease fee, it does not directly follow from section 1071 of the Civil Law and section 13 of the law "On Residential Properties". It has been noted in the case law that section 1068, section 1069 and section 1071 of the Civil Law provides for the right of an apartment owner, who at the same time is also the joint owner of the land property, to receive the lease fee from other joint owners of the building, proportionally to the undivided share of the land in his ownership. Simultaneously this apartment owner has the obligation to pay the lease fee to the other joint owners of the land, proportionally to the undivided share of the building in his ownership (i.e. proportionally to the apartment size) ${ }^{47}$

To resolve the aforementioned problem, the law "On Administration of Residential Houses" should include an exemption from the general rule of section 1069 and section 1071 of the Civil Law. If an apartment owner is also the owner of undivided shares of the land plot, then the obligation to pay the lease and the amount of lease fee should be calculated as if an agreement had been reached by the joint owners regarding divided use of the land plot in joint ownership. Namely, it should be recognised that each apartment owner, who at the same time is also the owner of the land, uses the undivided share of the land property in his ownership, whereas those apartment owners, who are not landowners at the same time, use the undivided shares of the landowner, who is not at the same time an apartment owner, and pay him the lease fee.

\subsubsection{Determining Land Plot for Buyout}

To commence the buyout of the land if the initiative for buyout is taken by one or few apartment owners, a mandatory obligation to review the borders of the land plot that is functionally necessary for the building prior to that should be stipulated in the law. This would ensure that the borders and the area of the bought land plot will no longer change and that all apartment owners of the building will exercise the buyout rights with respect to the same land plot. All interested persons (addressees) should be informed about the administrative act, by which the competent state or local government institution determines the borders and the area of the land plot to be bought-out, as currently stipulated by section 85 of the law "On Privatisation

47 Judgement of 15 February 2017 by the Riga City Vidzeme Suburb Court in case No. C30708816. Available: https://manas.tiesas.lv/eTiesasMvc/nolemumi/pdf/304687.pdf [last viewed 18.08.2018]. 
of State and Local Government Residential Houses". After this administrative act has entered into force, the area of the functionally necessary land plot shall no longer be altered. This means that the first purchase agreement on the undivided shares of land may be concluded only after the functionally necessary land plot for maintaining the building has been permanently determined and reviewed.

\subsubsection{Registration of Title to Property in Land Register}

Successful implementation of Model 2 requires improvements to the legal regulation with regard to making entries into the Land Register. Currently, an apartment owner, upon acquiring ownership of undivided shares of the land, may register its ownership only in that division of the Land Register, in which the land property has been entered. Thus, the ownership of separate parts of the property is not unified. The ownership is unified only if the respective undivided shares of the land property are registered as part of the apartment property, amending the composition of the apartment property in the subdivision of the Land Register. The Land Register Law in force do not contain the regulation providing that the composition of the apartment property could be changed upon acquiring the undivided shares of land; however, exactly in this way, contrary to the grammatical wording of the law but in accordance with common sense, the undivided shares of land previously owned by the state are added to an apartment property that has been already privatised and entered into the Land Register, thus merging the ownership of the building (apartment) and the land. ${ }^{48}$

If apartment owners buy out the undivided shares of the land property, to unify the ownership of the property, the amount of undivided shares the landowner owns should be accordingly decreased in the division of the Land Register where the land is corroborated. However, the apartment owners' titles to the undivided shares of the land are to be registered in the building's division of the Land Register (the composition of both properties is to be amended), or both properties are to be registered in one Land Register division. ${ }^{49}$ It should be emphasized that exactly by initial entering of the different parts (the land and buildings) of immovable property into separate divisions of Land Register, the dualistic system of immovable property was created. ${ }^{50}$ Consequently, the title to undivided shares should be registered in the sub-division of the particular apartment, adding, accordingly, that the particular apartment property consists not only of the undivided share of the building in joint ownership but also of the undivided share of the particular land plot. Such registration of the title to property would also resolve the problem of collecting the lease fees for the land that has not been bought out - if the undivided shares of the land owned by the apartment owner are no longer corroborated in the land plot's division of the Land Register, the classical joint ownership in the meaning of section 1068 of the Civil Law no longer forms. This also prevents the fragmentation of the title to land property.

In summary, it can be concluded that it is possible and necessary to incorporate into the law a procedure that would allow full or partial unification of ownership

48 Compare, e.g. division No. 100000209366 of the Land Register of Riga City - joint ownership established, and division No. 100000233353 of the Land Register of Venstpils City and sub-division No. 22787 of Riga City, where the undivided share of the land plot of the joint property has been added.

49 Compare, e.g., division No. 100000233353 of the Land Register of Ventspils City.

50 Rozenfelds, J. Superficies solo cedit Latvijas tiesibās [Superficies solo cedit in the Latvian Law]. Latvijas Universitātes žurnāls. Juridiskā zinātne. Vol. 3. Rìga: Latvijas Universitāte, 2012, p. 116. 
on the basis of an agreement reached by a landowner and one or several apartment owners. For this purpose, amendments have to be introduced into the Land Register Law that would disallow fragmentation of the title to land property and would ensure gradual unification of ownership by voluntary buyout of the undivided shares of land property. The only drawback of this model is that either apartment owners or landowners might lack incentives to agree on the purchase of the undivided share of land. This causes an obstacle for voluntary buyout. A significant advantage of the model of voluntary buyout is that it does not require additional financial resources from the State.

\subsection{Expropriation of Land Property to Transfer It for Privatisation (Model 3)}

In May 2018, in accordance with the provisions of the first part of para. $131^{3}$ of the Saeima Rules of Procedure, the Saeima of the Republic of Latvia received a citizens' collective application “The land beneath multi-apartment buildings should be owned only by the owners of these buildings". It contained the initiative that the title of land property should be transferred to the residents of the buildings, imposing an obligation on the State to disburse to the landowner the value of land, or to grant another, equivalent plot of land. ${ }^{51}$

This model of termination of separated ownership envisages expropriation of the land in favour of the State or the local government. Moreover, this would be mass-scale expropriation, which could be treated as nationalisation, thus violating the right to property enshrined in the Satversme. Subsequent privatisation of land plots could be done according to the procedure set in the privatisation laws since the provisions of the law "On Prevention of Squandering of the Financial Resources and Property of a Public Person" prohibits transferring the state-owned plots of land into the ownership of apartment owners free of charge.

\subsubsection{Financing Required to Implement the Model}

For state to buy out all land being part of properties with separated ownership, financing in the amount of the value of the land would be necessary. This amount currently has been calculated within the limits from 130 to 180 million euro up to even 300 million euro. ${ }^{52}$ These are considerable sums, compared to the total costs for unifying separated ownership in Model 1, which in the period from 2021 to 2038 are estimated as amounting to 38 million euro. ${ }^{53}$ However, Model 3 allows to attract financial recourses from outside the state budget, on the basis of public-private partnership. Envisaging these resources in the state budget would cause a deficit,

51 Available: https://manabalss.lv/zemei-jabut-maju-iedzivotaju-ipasuma [last viewed 18.12.2018].

52 Ministru kabineta atbilde Nr. 18/TA-2000. Par Latvijas pilsoṇu kolektivvo iesniegumu "Zemei zem daudzdzīvokḷu mājām jābūt tikai šo māju iedzīvotāju īpašumā” [The Cabinet of Ministers. Reply No. 18/TA-2000. On the collective application by the citizens of Latvia "The land beneath multi-apartment buildings should be owned only by the owners of these buildings"]. Available: http://tap.mk.gov.lv/doc/2018_10/TMVest_221018_Dalita_izbeigsa.2000.docx [last viewed 19.11.2018].

53 Latvijas Republikas Saeimas Valsts pārvaldes un pašvaldības komisija. Anotācija pie likumprojekta "Piespiedu dalītā īpašuma privatizētajās daudzdzīvokḷu mājās izbeigšanas likums" (Nr. 1211/Lp12) [Public Administration and Local Government Committee of the Saeima of the Republic of Latvia, annotation to the draft law "Law on Terminating the Enforced Separated Ownership in the Privatised Multi-apartment Buildings" (No. 1211/Lp12)]. Available: http://titania.saeima.lv/LIVS12/saeimalivs12.nsf/0/5986C97B49BD24A3C225826D004B1314 [last viewed 30.07.2018]. 
which in turn would infringe the norms of the Stability and Growth Pact of the European Union.

\subsubsection{Violation of Article 105 of the Satversme}

The right to property is protected both by para. 1 of the First Protocol to the European Convention for the Protection of Human Rights and Fundamental Freedoms and article 105 of the Satversme. The European Court of Human Rights, in interpreting para. 1 of the First Protocol, has noted that the State has the right to control the use of property, inter alia, by legislation, which in certain cases allows compulsory transfer of property from one individual to another. The court concluded that the taking of property in pursuance of a policy calculated to enhance social justice within the community can be described as being "in the public interest". ${ }^{4}$ These findings, which are often quoted in the context of unifying the separated ownership, were included in a judgement, which examined the right of tenants to purchase compulsorily the 'freehold' of the property. Namely, this legislation provided occupying tenants of 'houses' let on long leases in England and Wales with the right to acquire the freehold of the house. The basic principle of a contested reform was that leaseholders are 'morally entitled' to the ownership of the building which they have put on and maintained. This finding, possibly, can be applied also to the legal regulation that provides for buyout rights of apartment owners against the landowner's will; however, it does not give grounds for the assumption that the Convention would allow expropriation of all land properties with buildings on them.

The Constitutional Court of the Republic of Latvia in its cases has repeatedly emphasised the criteria for expropriation referred to in the third sentence of article 105 of the Satversme. The Constitutional Court has pointed out that coercive expropriation of property shall be allowed only: 1) on the basis of a specific law; 2) for public needs; 3) in an exceptional cases, 4) for fair compensation. ${ }^{55}$ Section 3 of the law "On Expropriation of Immovable Property for the Needs of the State or for Public Needs" provides that a special law is adopted on the expropriation of each immovable property, if the state or the local government is unable to obtain the respective immovable property by agreeing with the owner. In this procedure, each owner has the right to be heard.

The Constitutional Court has, in particular, underscored that coercive expropriation of real estate cannot become a usual practice for meeting the needs of the State. The legislature must be convinced that there are no other solutions for ensuring the public needs and that each property expropriation should be regarded as an exceptional case. ${ }^{56}$ These criteria are not met in the case of separated ownership because, even if it could be assumed that expropriation of the land properties, which the apartment owners do not want to buy out, are expropriated for a public need, this measure would not be appropriate - encumbering the society in general (the state budget) to ensure to a part of the owners of apartment buildings

54 Judgement of 21 February 1986 by the European Court of Human Rights in case James and Others vs. the United Kingdom, appl. No. 8793/79. Available: http://hudoc.echr.coe.int/eng?i=001-57507 [last viewed 17.11.2018], $\$ 39,41,45$.

55 Judgement of 21 October 2009 by the Constitutional Court of the Republic of Latvia in case No. 2009-01-01. Latvijas Vēstnesis, No. 170(4156), 2009. Available: http://www.satv.tiesa.gov.lv/ web/viewer.html?file=/wp-content/uploads/2009/01/2009-01-01_Spriedums_ENG.pdf [last viewed 15.06.2019], para. 10

56 Ibid., para. 13.3 
the possibility to acquire in their ownership the land beneath these buildings. The State's primary task is to ensure appropriate regulation for situation when the apartment owners want to buy out the land property, rather than to expropriate all these properties.

In summing up, it can be concluded that Model 3, containing rules for the State to expropriate all land properties so that apartment owners could privatise these later, only prima facie seems to be a relatively simple way for unifying the separated ownership. If the State were to choose this approach, it would be unlawful and, definitely, would not stand the test of constitutionality.

Investing the budget resources into buyout of the land would also jeopardise compliance with the limits of budget deficit set by the European Commission. Implementation of the mass-scale expropriation model, referred to above, would be unacceptable in a democratic state governed by the rule of law; rather, the willingness of the house owners and landowners to agree on voluntary buyout should be promoted by creating an appropriate legal mechanism for it, the basic principles of which are presented in the description of Model 2.

\section{The Amount of Land Lease Fee and Lease Collection During Buyout Process}

Irrespectively of the model that the legislature will choose for unifying the separated ownership, until the completion of buyout, between the landowners and the apartment owners there will be the legal relationship of compulsory land lease. Since unification of ownership is preferred from the public policy perspective, it should be taken into account that the apartment owner's decision on buying out the land plot is the direct result from their previous experience with land lease payments. Usually, apartment owners show interest in buyout only after the landowner has begun lease fee collection as the title to the land under the building does not give to the apartment owner almost any advantages compared to the lease.

The larger the amount of the land lease fee, the more frequently apartment owners express interest in buying out the land in order to not pay the lease. Whereas in properties, where the lease fee is insignificant or the landowner, for various reasons, has been unable to collect it altogether, the interest in buying-out the land is minimal. ${ }^{57}$ The apartment owner retains the interest in buying the land only if he has the possibility to decrease his expenses; i.e., the expected buyout price, which would be paid gradually, is lower than the lease fee. Landowners usually take a more pragmatic approach to selling of land, and they usually have doubts regarding the fair price. ${ }^{58}$

Therefore, one of the most appropriate and legally valid ways to promote the unifying of the separated ownership is to provide incentives for apartment owners to buy out voluntarily the land plots beneath the buildings. This can be done by providing the possibility to buy out the land on favourable terms, at the same time eliminating the restrictions on the amount of land lease fee and simplifying the procedure for collecting lease payments. To achieve this aim, it should be financially more advantageous for the apartment owners to obtain the title to property rather

\footnotetext{
57 An interview with A. Brečs, co-chairman of the association "Land Reform Committee", uniting landowners, 07.07.2018.

58 Bèrtule, A. Atbalsta piespiedu dalìtā īpašuma izbeigšanu [Support for the Termination of Enforced Separated Ownership]. Lsm.lv, 28.02.2018. Available: https://www.lsm.lv/raksts/zinas/ekonomika/ atbalsta-piespiedu-dalita-ipasuma-izbeigsanu.a269729/ kilnieki [last viewed 20.10.2018].
} 
than continue leasing it. The State, without infringing the principles of a state governed by the rule of law, may provide incentives to encourage private persons to take certain actions, envisaging the onset of comparatively more adverse financial consequences if the person fails to act. For example, the legislature has promoted timely registration of ownership rights by determining that the state fee for registering ownership rights in the Land Register shall be determined by applying ratio of 1.5, if more than 6 months have passed, counting from the day of signing the document that confirms the rights to be registered. ${ }^{59}$

The amendments adopted in the summer of 2017 to section 54 "On Privatisation of State and Local Government Residential Houses" and to section 12 of the law "On Land Reform in Cities of the Republic of Latvia", essentially, came in conflict with the declared public policy to unify the separated ownership since it diminished the apartment owners' economic interest in buyout of the land. Due to the provision in the law stipulating that land lease payment would decrease and it shall not be higher, respectively, than 5\% in 2018, 4\% in 2019 and not higher than $3 \%$ in 2020 of the cadastral value of land, the apartment owners are no longer interested in buying the land since the expected buyout price exceeds the land lease fee. At the same time, as also found by the Constitutional Court, the fundamental right of landowners to receive appropriate revenue was unfoundedly and disproportionally restricted. In addition, the possibility to collect the lease fees through the court was encumbered, since the law no longer sets the particular amount of the lease fee in case when an agreement was not reached between landowner and apartment owners. ${ }^{60}$

Taking into consideration the aim of public policy to promote the unifying of separated ownership, the legislature should abandon the attempts to legislate for an unfoundedly low amount of the lease fee. The lease fee should correspond to normal revenue from property; moreover, the rate of return (profitability) should be such to recover the value of property within 10-15 years. ${ }^{61}$ Having regard to the landowners' obligation to pay the real estate tax and to pay the personal income tax at least in the amount of $10 \%$ of the received lease payments, the current (cadastral) value of the property can be recovered within 13-17 years, if the annual land lease fee constitutes $8-10 \%$ of the cadastral value, whereas with the lease fee in the amount of $3 \%$ of the cadastral value of the land, the (current cadastral) value of the property can be recovered in approximately 85 years (see table below).

59 Grozijumi Ministru kabineta 2009. gada 27. oktobra noteikumos Nr. 1250 "Noteikumi par valsts nodevu par īpašuma tiesību un k̦ilas tiesību nostiprināšanu zemesgrāmatā” [Amendments to the Cabinet Regulation of 27 October 2009 No. 1250 "Regulation Regarding State Fee for Registering Ownership Rights and Pledge Rights in the Land Register"]. Latvijas Vèstnesis, No. 230(5036), 25.11.2013. OP No. 2013/230.3. Available: https:/likumi.lv/ta/en/en/id/200087-regulationregarding-state-fee-for-registering-ownership-rights-and-pledge-rights-in-the-land-register [last viewed 15.06.2019].

60 Judgement of 12 April 2018 by the Constitutional Court of the Republic of Latvia in the case No. 2017-17-01. Latvijas Vēstnesis, No. 74(6160), 2018. Available in English: http://www.satv. tiesa.gov.lv/en/press-release/the-norms-which-as-of-1-january-2018-decrease-the-amount-ofcompulsory-land-lease-are-incompatible-with-the-satversme/ [last viewed 15.06.2019].

61 Standard \& Poor's 500 average capitalisation rates of investments. 


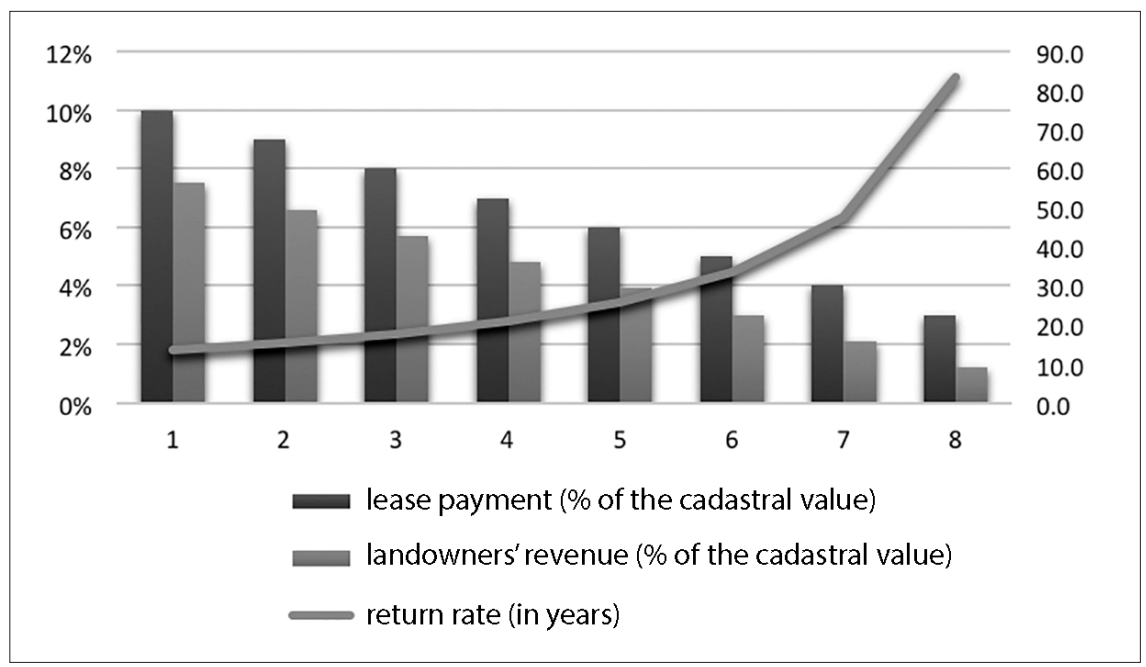

The legislature has various measures at its disposal for promoting the apartment owners' interest in buying out of the land. This includes state aid for setting decreased interest rates for mortgage loans for buyout, as well as real estate tax reliefs for those apartment owners, who buy the land. In this way, an apartment owner, by paying the amount which corresponds, for example, to $6 \%$ annually of the cadastral value of the property, would be able to fully buy out the undivided share of the land property within 15-20 years.

At the same time, the legislature must take reasonable steps to make the collection of lease fees easier and to facilitate the awareness among apartment owners that paying the lease is their statutory duty. For example, it could be provided in the law that the calculation, which the landowner has made in accordance with the laws, is a sufficient proof and legal grounds for the claim that has been brought to the court, while the duty to rise any objections should be transferred to the defendant. ${ }^{62}$ The recovery of lease fees should be as simple as the recovery of the real estate tax. This would ensure the landowners' right to gain revenue from their property and would facilitate the apartment owners' interest in buying the land.

\section{Summary}

1. Separated ownership of property exists and currently remains a legal reality in Latvia, as are the compulsory land lease and challenges of collecting the lease fees. Some members of Parliament have argued in favour of compulsory unification of the ownership of these properties. However, the legislature has a choice. A radical solution would be expropriation, but such a solution would infringe upon the human rights enshrined in the Satversme. On the other hand, it can adapt legislation that would allow apartment owners to buy out the land. Thus, the State should work towards a public policy encouraging persons to voluntarily agree to buy out the land. This option or Model 2, examined in

62 Compare, "Par nekustamā īpašuma nodokli" [On Immovable Property Tax]. Latvijas Vēstnesis, No. 145, 17.06.1997, Ziņotājs, No. 13, 03.07.1997. Available: https://ikumi.lv/ta/en/en/id/43913-onimmovable-property-tax [last viewed 15.06.2019], section 10. 
the article, would be the solution that takes into consideration the fundamental rights guaranteed in the Satversme pertaining to all the involved parties.

2. The State has the obligation to ensure that those owners of land and buildings, who are already willing to agree on land purchase conditions, could buy out the land and register their title to the property in a way that unifies the separated ownership. It is in the hands of the legislature to amend some of the provisions regulating corroboration of immovable properties to ensure that unification of ownership is possible when apartment owners buy the undivided shares of the land plot that the apartment is entitled to.

3. To promote the buyout process, some financial incentives are required for the apartment owners to use their buyout rights. This can be achieved, if the price of land is the same or even below the land lease fee. Legislative amendments that are aimed at decreasing the lease fee do not serve this purpose, since low lease fee shall not encourage the apartment owners to buy out the land.

4. Simultaneously, the issues related to the collection of land lease fees are to be resolved. Collection procedure should become simple and effective, granting the landowner the right to choose, whether the matters of lease should be dealt with through the manager of the building or by bringing a claim against the separate apartment owners. In the absence of an agreement the law should set the amount of the lease fee, so that the courts would not have to decide on disputes regarding it. The criteria for calculating the land lease fee should be clearly defined, imposing the obligation to contest the calculation on the defendant.

5. The legal capacity and capacity of being a party to court proceedings of the community of apartment owners should be stipulated in the law. The law should also contain provisions on representation of the community of apartment owners. This would facilitate and accelerate the examination of claims that have been brought against the community of apartment owners. The law should provide that a community of the apartment owners is represented in court by the manager. The law should also define the scope of the powers of the manager, stipulating that it has the rights and obligations to conduct cases, exercise rights and assume obligations instead and on behalf of the community of apartment owners, unless the apartment owners have agreed on authorising another representative with the aforementioned scope of the powers.

\section{Sources}

\section{Bibliography}

1. Balodis, K. Komentārs pie Satversmes 105. panta [Commentary on Article 105 of the Satversme]. In: Latvijas Republikas Satversmes komentāri. VIII nodaļa. Cilvēka pamattiesības. Rīga: Latvijas Vēstnesis, 2011, p. 459.

2. Bērtule, A. Atbalsta piespiedu dalītā īpašuma izbeigšanu [Support for the Termination of Enforced Separated Ownership]. Lsm.lv, 28.02.2018. Available: https://www.lsm.lv/raksts/zinas/ekonomika/ atbalsta-piespiedu-dalita-ipasuma-izbeigsanu.a269729/ kilnieki [last viewed 20.10.2018].

3. Blacksell, M., Born, K. M. Private Property Restitution: The Geographical Consequences of Official Government Policies in Central and Eastern Europe. The Geographical Journal, No. 168(2), June, 2002. Available: https://www.jstor.org/stable/3451616 [last viewed on 24.09.2018], pp. 178-190.

4. Diskusijas un jautājumi Civiltiesību sekcijā [Discussions and Questions in the Civil Law Section]. Latvijas Republikas Augstākās tiesas biḷetens, No. 3, December 2011, p. 23.

5. Dzedulis, Z. Zemes nomas kiilnieki [Hostages of Land Lease]. Latvijas Avīze, 17.08.2018. Available: http://www.la.lv/zemes-nomas-kilnieki [last viewed 20.10.2018]. 
6. Endziņš, A. Latvijas konstitūcijas apskats, kas rada šaubas un jautājumus [Overview of the Latvian Constitution, which Causes Doubts and Questions]. Jurista Vārds, No. 8(363), 01.03.2005, pp. 4-5.

7. Feldman, M. Justice in space? The restitution of property rights in Tallinn, Estonia. Ecumene, No. 6(2), April 1999. Available: https://www.jstor.org/stable/44252046 [last viewed 24.09.2018], pp. $165-182$.

8. Grūtups, A., Kalniņš, E. Civillikuma komentāri. Trešā daḷa. Lietu tiesības. İpašums [Commentaries on the Civil Law. Part Three. Rights in Rem. Property]. $2^{\text {nd }}$ enlarged edition. Rìga: Tiesu namu aǵentūra, 2002.

9. Grūtups, A., Krastiņšs, E. Īpašuma reforma Latvijā [Property Reform in Latvia]. Rīga: Mans Īpašums, 1995.

10. Pogany, I. Righting wrongs in Eastern Europe. Manchester, New York: Manchester University Press, 1997.

11. Rozenfelds, J. Pētījums par Civillikuma Lietu tiesību daḷas (ceturtās, piektās, sestās un septītās nodaḷas) modernizācijas nepieciešamību [Study of the Need to Modernise the Part on Rights in Rem, Chapter Four, Five, Six and Seven]. 2008. Available: http://www.tm.gov.lv/files/archieve/ lv_documents_petijumi_cl_ceturta_piekta_sesta_un_septita_nodala.doc [last viewed 30.09.2018].

12. Rozenfelds, J. Superficies solo cedit Latvijas tiesībās [Superficies solo cedit in the Latvian Law]. Latvijas Universitātes žurnāls. Juridiskā zinātne 3. sējums. Rīga: Latvijas Universitāte, 2012, pp. 105-119.

13. Torgāns, K. (ed.). Latvijas Republikas Civillikuma komentāri. Saistību tiesības [Commentaries on the Civil Law of the Republic of Latvia. Obligations Law]. $2^{\text {nd }}$ edition. Rīga: Mans İpašums, 2000.

14. Torgāns, K. Saistību tiesības. II daḷa [Obligations Law. Part II]. Rīga: Tiesu namu aǵentūra, 2008.

15. Vèbers, J. (ed.). Latvijas PSR Civilkodeksa komentāri [Commentaries on the Civil Code of the Latvian SSR]. Rīga: Liesma, 1979.

\section{Normative Acts}

1. Autortiesību kolektīvā pārvaldījuma likums [Law on Collective Management of Copyright]. Latvijas Vēstnesis, No. 106(5933), 31.05.2017. Available: https://likumi.lv/ta/en/en/id/291146-lawon-collective-management-of-copyright [last viewed 15.06.2019].

2. Civillikums [The Civil Law]. Valdības Vēstnesis, No. 46, 26.02.1937. Available: https://likumi.lv/ta/ en/en/id/225418-the-civil-law [last viewed 15.06.2019].

3. Dzīvokḷa īpašuma likums [Law On Residential Properties]. Latvijas Vēstnesis, No. 183(4375), 17.11.2010. Available: https://likumi.lv/ta/en/en/id/221382-law-on-residential-properties [last viewed 15.06.2019].

4. Grozijumi Ministru kabineta 2009. gada 27. oktobra noteikumos Nr. 1250 "Noteikumi par valsts nodevu par īpašuma tiesību un k̦īlas tiesību nostiprināšanu zemesgrāmatā" [Amendments to the Cabinet Regulation of 27 October 2009 No. 1250 "Regulation Regarding State Fee for Registering Ownership Rights and Pledge Rights in the Land Register"]. Latvijas Vèstnesis, No. 230(5036), 25.11.2013. OP No. 2013/230.3. Available: https://likumi.lv/ta/en/en/id/200087-regulationregarding-state-fee-for-registering-ownership-rights-and-pledge-rights-in-the-land-register [last viewed 15.06.2019].

5. Grozījums Ministru kabineta 2010. gada 13. septembra rīkojumā Nr. 541 "Par Koncepciju par Civillikuma lietu tiesību daļas modernizāciju" [Amendment to the Cabinet Order of 13 September 2010 No. 541 "On the Concept Paper on Modernising the Part on Rights in Rem of the Civil Law]. Latvijas Vēstnesis, No. 94(4697), 15.02.2012.

6. Par atjaunotā Latvijas Republikas 1937. gada Civillikuma ievada, mantojuma tiesību un lietu tiesību daḷas spēkā stāšanās laiku un kārtību [On the Date and Procedure for Entering into Force of the Introduction, Part on Inheritance Rights and Rights in Rem]. Ziņotājs, No. 29, 30.07.1992, Diena, No. 135, 24.07.1992.

7. Par Latvijas Republikas 1937. gada Civillikumu [On the Civil Law of the Republic of Latvia of 1937]. Ziņotājs, No. 4/5, 30.01.1992.

8. Par Latvijas Republikas neatkarïbas atjaunošanu [On Restoration of the Independence of the Republic of Latvia]. Ziņotājs, No. 20, 17.05.1990.

9. Par nekustamā īpašuma nodokli [On Immovable Property Tax]. Latvijas Vēstnesis, No. 145, 17.06.1997, Ziņotājs, No. 13, 03.07.1997. Available: https://likumi.lv/ta/en/en/id/43913-onimmovable-property-tax [last viewed 15.06.2019].

10. Piliečių Nuosavybès Teisių I Išlikusị Nekilnojamąji Turtą Atkūrimo İstatymas [On Restitution of Citizens' Title to Property on Existing Immovable Property]. Available: https://e-seimas.lrs.lt/ portal/legalActPrint/lt?jfwid=5sjolg0fi\&documentId=TAIS.364111\&category=TAD [last viewed 25.09.2018]. 
11. Par valsts īpašumu un tā konversijas pamatprincipiem [On State Property and the Principles of Conversion thereof]. Zinotäjs, No. 19/20, 23.05.1991, Diena, No. 69, 11.04.1991.

12. Par valsts un pašvaldību dzīvojamo māju privatizāciju [On Privatisation of State and Local Government Residential Houses]. Latvijas Vēstnesis, No. 103(386), 11.07.1995, Ziņotājs, No. 16, 24.08.1995.

13. Par zemes reformu Latvijas Republikas pilsētās [On Land Reform in Cities of the Republic of Latvia]. Ziñotājs, No. 49/50, 19.12.1991, Diena, No. 242, 13.12.1991.

14. Rīgas brīvostas likums [The Free Port of Riga Law]. Latvijas Vēstnesis, No. 111/112(2022/2023), 28.03.2000, Ziñotājs, No. 8, 20.04.2000. Available: https://likumi.lv/ta/en/en/id/3435-the-free-portof-riga-law [last viewed 15.06.2019].

15. Ventspils brīvostas likums [The Free Port of Ventspils Law]. Latvijas Vēstnesis, No. 1/2(716/717), 03.01.1997, Zinotājs, No. 3, 13.02.1997. Available: https:/likumi.lv/ta/en/en/id/41737-the-freeport-of-ventspils-law [last viewed 15.06.2019].

16. Maareformi seadus [Land Reform Act]. RT, 1991, 34, 426, Available: https://www.riigiteataja.ee/en/ eli/529062016001/consolide [last viewed 25.09.2018].

\section{Travaux Preparatoires}

1. AS "Latvenergo" 08.02.2009. atzinums "Par likumprojektu Dzīvojamo māju pārvaldīšanas likums" [Joint Stock Company "Latvenergo". Opinion "On the Draft Law on Management of Residential Buildings"]. Available: http://titania.saeima.lv/LIVS/SaeimaLIVS.nsf/0/d9a4e435aaab22a6c225759 80021038c/\$FILE/1438-Jur.pdf [last viewed 30.10.2018].

2. Latvijas Republikas 12. Saeimas 2016. gada 17. marta sēdes stenogramma [Transcript of the Sitting of the $12^{\text {th }}$ Saeima of the Republic of Latvia on 17 March 2016]. Available: http://titania.saeima. lv/LIVS12/saeimalivs12.nsf/0/FAF4C0D35BA5CCE9C2257F8C0023E471 [last viewed 16.08.2018].

3. Latvijas Republikas Saeimas Juridiskais birojs. Atzinums par likumprojektu "Piespiedu dalìtā ìpašuma privatizētajās daudzdzīvokḷı mājās izbeigšanas likums" [Legal Bureau of the Saeima of the Republic of Latvia. Opinion on the draft law "Law on Terminating the Enforced Separated Ownership in Privatised Multi-apartment Buildings]. Available: http://titania.saeima.lv/LIVS12/ saeimalivs12.nsf/0/1036916E0888874EC2258294002A933D [last viewed 21.10.2018].

4. Latvijas Republikas Saeimas Valsts pārvaldes un pašvaldības komisija. Anotācija pie likumprojekta "Piespiedu dalītā īpašuma privatizētajās daudzdzīvokḷu mājās izbeigšanas likums" (Nr. 1211/Lp12) [Public Administration and Local Government Committee of the Saeima of the Republic of Latvia "Law on Terminating the Enforced Separated Ownership in the Privatised Multi-apartment Buildings" (No. 1211/Lp12)]. Available: http://titania.saeima.lv/LIVS12/ saeimalivs12.nsf/0/5986C97B49BD24A3C225826D004B1314 [last viewed 30.07.2018].

5. Likumprojekts "Piespiedu dalītā īpašuma privatizētajās daudzdzìvokḷu mājās izbeigšanas likums" [Draft law "Law on Terminating the Enforced Separated Ownership in the Privatised Multiapartment Buildings"]. Available: http://titania.saeima.lv/LIVS12/saeimalivs12.nsf/webSasaiste? OpenView\&restricttocategory=1211/Lp12 [last viewed 30.10.2018].

6. Ministru kabinets. Atbilde Nr. 18/TA-2000. Par Latvijas pilsonnu kolektīvo iesniegumu "Zemei zem daudzdzìvokḷu mājām jābūt tikai šo māju iedzīvotāju īpašumā" [The Cabinet of Ministers. Reply No. 18/TA-2000. On the collective application by the citizens of Latvia "The land beneath multi-apartment buildings should be owned only by the owners of these buildings"]. Available: http://tap.mk.gov.lv/doc/2018_10/TMVest_221018_Dalita_izbeigsa.2000.docx [last viewed 19.11.2018].

\section{Case Law}

1. Judgement of 21 February 1986 by the European Court of Human Rights in case James and Others vs. the United Kingdom, appl. No. 8793/79. Available: http://hudoc.echr.coe.int/eng?i=001-57507 [last viewed 17.11.2018].

2. Judgement of 30 May 2014 by the Department of Civil Cases of the Supreme Court of the Republic of Latvia in case No. SKC-1208/2014]. Available: https://manas.tiesas.lv/eTiesasMvc/nolemumi/ pdf/161961.pdf [last viewed 22.10.2018].

3. Judgement of 7 October 2015 by the Department of Civil Cases of the Supreme Court of the Republic of Latvia in case No. SKC-201/2015. Available: https://manas.tiesas.lv/eTiesasMvc/nolemumi/ pdf/235206.pdf [last viewed 31.10.2018].

4. Judgement of 23 November 2016 by the Department of Civil Cases of the Supreme Court of the Republic of Latvia in case No. SKC-287/2016 (C20136206). Available: http://31.24.192.35/ downloadlawfile/611 [last viewed 14.06.2018]. 
5. Judgement of 30 May 2016 by the Department of Civil Cases of the Supreme Court of the Republic of Latvia in case No. SKC-118/2016. Available: http://31.24.192.35/downloadlawfile/677 [last viewed 14.06.2018].

6. Judgement of 17 June 2016 by the Department of Civil Cases of the Supreme Court of the Republic of Latvia in case No. SKC-252/2016 (C28135508). Available: https://manas.tiesas.lv/eTiesasMvc/ nolemumi/pdf/270517.pdf [last viewed 14.06.2018].

7. Judgement of 14 September 2009 by the Department of Civil Cases of the Supreme Court of the Republic of Latvia in case No. PAC-1734/2009 (C01173409). Available: http://www.zemesgramata. lv/likumi/lemumi/pac-1734.doc [last viewed 21.10.2018].

8. Judgement of 29 September 2010 by the Senate of the Supreme Court of the Republic of Latvia in case No. SKC-182/2010 (C30234305). Unpublished.

9. Judgement of 15 September 2010 by the Department of Civil Cases of the Supreme Court of the Republic of Latvia in case No. SKC-174/2010 (C04355106). Unpublished.

10. Judgement of 13 February 2009 by the Constitutional Court of the Republic of Latvia in case No. 2008-34-01. Latvijas Vēstnesis, No. 27(4013). Available: http://www.satv.tiesa.gov.lv/web/ viewer.html?file=/wp-content/uploads/2008/07/2008-34-01_Spriedums_ENG.pdf [last viewed 15.06.2019].

11. Judgement of 21 October 2009 by the Constitutional Court of the Republic of Latvia in case No. 2009-01-01. Latvijas Vēstnesis, No. 170(4156). Available: http://www.satv.tiesa.gov.lv/web/ viewer.html?file=/wp-content/uploads/2009/01/2009-01-01_Spriedums_ENG.pdf [last viewed 15.06.2019].

12. Judgement of 25 October 2011 by the Constitutional Court of the Republic of Latvia in case No. 2011-01-01. Latvijas Vēstnesis, No. 171(4569). Available: http://www.satv.tiesa.gov.lv/web/ viewer.html?file=/wp-content/uploads/2011/01/2011-01-01_Spriedums_ENG.pdf [last viewed 15.06.2019].

13. Judgement of 9 January 2014 by the Constitutional Court of the Republic of Latvia in case No. 2013-08-01. Latvijas Vēstnesis, No. 8(5067). Available: http://www.satv.tiesa.gov.lv/web/ viewer.html?file=/wp-content/uploads/2013/04/2013-08-01_Spriedums_ENG.pdf [last viewed 15.06.2019].

14. Judgement of 12 April 2018 by the Constitutional Court of the Republic of Latvia in case No. 2017-17-01. Latvijas Vēstnesis, No. 74(6160). Available in English: http://www.satv.tiesa.gov. lv/en/press-release/the-norms-which-as-of-1-january-2018-decrease-the-amount-of-compulsoryland-lease-are-incompatible-with-the-satversme/ [last viewed 15.06.2019].

15. Judgement of 15 February 2017 by the Riga City Vidzeme Suburb Court in case No. C30708816. Available: https://manas.tiesas.lv/eTiesasMvc/nolemumi/pdf/304687.pdf [last viewed 18.08.2018].

\section{Other Sources}

1. Latvijas Republikas Tieslietu ministrija. Dalītais ippašums [The Ministry of Justice of the Republic of Latvia. Separated ownership]. Available: http://onecrm.lv/lps/meetingsearch/displaydocument. aspx? committeename $=$ Tehnisko\%20probl\%BAmu\%20komiteja\&itemid $=24635919229989771030 \&$ meetingid=1602005K\%20\%20\%20\%20\%20\%20\%20\&filename=Dal\%EFtais\%20\%EFpa\%B9ums. pdf\&cc=Document [last viewed 24.01.2017].

2. The Constitutional Court of the Republic of Latvia. 12.04.2018. Press Conference on the Judgement in case No. 2017-17-01. Available: https://www.youtube.com/watch?v=x3MMD9962NI [last viewed 14.05.2018].

3. Valsts zemes dienests. Nekustamā īpašuma tirgus pārskats [The State Land Service. Overview of the Immovable Property Market]. Available: http://kadastralavertiba.lv/wp-content/uploads/2018/05/ Parskats_15052015_gala.pdf [last viewed 15.06.2018].

4. Kolektīvais iesniegums "Zemei zem daudzdzīvokḷu dzīvojamām mājām jābūt tikai šo māju iedzīvotāju ìpašumā" [Collective application "The land beneath multi-apartment buildings should be owned only by the owners of these buildings"]. Available: https://manabalss.lv/zemei-jabutmaju-iedzivotaju-ipasuma [last viewed 18.12.2018]. 


\title{
Legislative Intent of Act in Estonia
}

\author{
Dr. iur. Silvia Kaugia \\ Faculty of Law, University of Tartu \\ Lecturer in Comparative Jurisprudence, Department of Penal Law \\ E-mail: silvia.kaugia@ut.ee
}

It is in the interests of both the legislator and society that the law should be effective. In order to be effective, there are rules established for legislative drafting in Estonia, set forth in corresponding regulations.

Rules for Good Legislative Practice and Legislative Drafting (hea õigusloome ja normitehnika eeskiri, abbr. HÕNTE) provide for important steps in the legislative process to ensure a higher quality and efficiency of laws. Among other things, these rules introduced the legislative intent for drafting process, and the concept of draft Act, as well as the obligation to assess the impact and demonstrate corresponding results in the explanatory memorandum to the draft Act. This also expanded the scope of the interest group participation in the various stages of the legislative process.

Keywords: law making, legislative intent, stakeholder groups, effective law.

\section{Contents}

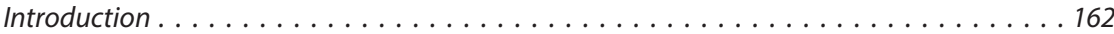

1. Law-Making Principles by Rules for Good Legislative Practice and Legislative Drafting . . . . . . . . . . . . . . . . . . . . . . . . . 163

2. Involvement of Stakeholder Groups in Law-Making . . . . . . . . . . . . . . . . . . 164

3. Initiation of Draft Legislation and Requirements for Formulation of Legal Provisions . . . . . . . . . . . . . . . . . . . . . . . . . . . . . . 165

4. Adoption of Legislation and Feedback to Legislative Drafting . . . . . . . . . . . . 167

Summary. . . . . . . . . . . . . . . . . . . . . . . . . . . . . . . . . . . . . . . 170

Sources . . . . . . . . . . . . . . . . . . . . . . . . . . . . . . . . . . . 171

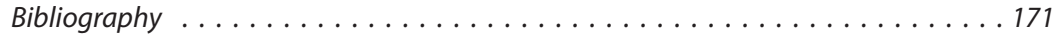

Normative Acts . . . . . . . . . . . . . . . . . . . . . . . . . 171

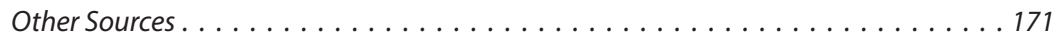

\section{Introduction}

The need for legislation grows out the emergence and occurrence of social relationships requiring legal regulation. It is in the interests of both the legislator and society that the law should be effective. However, to be effective, it is essential that the law should be based on social realities, and it should be understandable to those it addresses. In order to achieve this, there are rules established for 
legislative drafting in Estonia, set forth in corresponding regulations - Technical Rules for Draft Legislation Submitted for Legislative Proceedings of the Riigikogu ${ }^{1}$ established by the Board of the Riigikogu, Riigikogu Rules of Procedure and Internal Rules $\mathrm{Act}^{2}$ and Rules for Good Legislative Practice and Legislative Drafting $^{3}$, a Regulation of the Government of the Republic targeting government agencies, which entered into force in 2012.

The objective of regulation is to ensure that both legislative drafting and legislative changes are justified and comprehensible; this is achieved by conducting comprehensive impact assessment and consultations with target groups. It is important to achieve the correlation between laws and social reality, correspondence with vital needs and the clarity of regulation for those it addresses. The specific goal is to make the process of norm drafting more understandable for stakeholders. The purpose of this article is to analyze specific regulations and use that to draw conclusions on the possibilities of social orientation of legislative drafting in Estonia.

\section{Law-Making Principles by Rules for Good Legislative Practice and Legislative Drafting}

One of the most important innovations introduced by HÕNTE, is the comprehensive regulation of legislative intent. Section 1(1) of the rules set out the criteria that must be reflected in the legislative intent:

1) the field or the problem to be addressed and the target group;

2) the purpose;

3) possible policy options of resolving the issue, comparison of the options and the preferable option;

4) compatibility of the selected policy option with the current legal system;

5) policy option of resolving the issue in countries with a social order and legal system similar to Estonia;

6) description and structure of the planned legal instrument, including determination of the level of regulation, estimated date of completion of the draft and recommended validity period of the legal instrument;

7) which significant impact, based on the frequency and scope of the impact, the size of the target group and the risk of undesirable impact, may accompany the implementation of the Act;

8) how will the accompanying significant impact be analyzed and the reasons why certain accompanying impacts will not be analyzed;

9) action plan for further preparation of the draft Act;

10) other circumstances relevant to the resolution of the issue.

These requirements testify to the fact that it is not possible to tear the drafting of legislation from its social context and the needs of those it addresses to drafted legislation. Moreover, in addition to state organizations, the legislative process

1 Riigikogus menetletavate eelnõude normitehnika eeskiri [Technical Rules for Draft Legislation Submitted for Legislative Proceedings]. Available: https://www.riigikogu.ee/wpcms/wp-content/ uploads/2014/11/Riigikogus-menetletavate-eeln-ude-normitehnika-eeskiri.pdf [last viewed 02.05.2018].

2 Riigikogu kodu - ja töökorra seadus [Riigikogu Rules of Procedure and Internal Rules Act]. RT I, 28.06.2016, 22.

3 Hea õigusloome ja normitehnika eeskiri [Rules for Good Legislative Practice and Legislative Drafting]. RT I, 29.12.2011, 228. 
should include the target groups for drafted regulations, since legislative drafting is a co-operative process of many state bodies and social legislative forces.

\section{Involvement of Stakeholder Groups in Law-Making}

The first stage of legislative drafting is the analysis of the problem: the formulation of the problem, the assessment of the extent to which regulation is needed and what will be the objectives of the regulation. This is when various approaches are considered and the most proportionate measures chosen. "The successful functioning of the legal order can only be based on reliable and adequate sources."

At this stage, it is important to identify the relevant interest groups - their involvement will in most cases lead to a solution that closest to the objective.

According to HÕNTE $\$ 1(5)$, interest groups shall be involved in the preparation of a legislative intent, concept and draft Act and coordination carried out in compliance with the provisions of the Rules of the Government of the Republic and the Good Practice of Involvement established on the basis of subsection $4(2)^{5}$ of the Rules of the Government of the Republic. The Good Practice of Involvement ${ }^{6}$ provides, inter alia, that interest group consultations should take place at all stages of policy making - problem definition, setting objectives, analyzing solutions and decision drafting. This allows the interest groups to highlight different facets and factors of influence, thus ensuring the most adequate understanding of the subject of regulation. At the same time, it must be considered that such organization depends largely on the initiative of the interest group and its ability to chart the situation, which in turn may lead to gaps in problem description. This may result in regulation that does not fully meet its purpose or leads to new issues.

As a rule, the legislative activity of state bodies is triggered by the 'outside' impulses, the clash of interest between different social groups. Thus, the internal organization of interests and the conflict and sanctioning capabilities of the group as a whole are important factors in the legislative process.

The chance to advance their interests depends on the internal discipline of the organization. Opposing interests are harmonized within the organization, focusing solely on the interests representing social needs of a given group.

In addition to the organizational capacity of the interests established by legislative drafting, this also requires the conflict capacity of interested parties, which is often lacking in socially weak groups (e.g. unemployed, pensioners, homemakers, etc.). Due to their lack of organization and almost non-existent resources, they do not have the necessary power and authority, and thus do not have any sanction options, when their interests are not considered to a sufficient extent. Often, they have difficulties even with legislative information, because it is not uncommon that persons become aware of a new law only when it has already come into force or when they come into contact with it. Thus, the legislative drafting does not depend so much on the actual state of the interests of the people or on their

4 Narits, R. Seadusloome regulatiivse ja õigusliku mõju hindamine [Legal and Regulatory Impact Assessment of Legislation]. Riigikogu Toimetised, No. 4, 2001, p. 98.

5 Vabariigi Valitsuse reglement [Rules of the Government of the Republic]. RT I, 29.12.2011, 233.

6 Kaasamise hea tava [The Good Practice of Engagement]. Available: https://riigikantselei.ee/et/ kaasamise-hea-tava [last viewed 02.05.2018]. 
relationship, but instead on how successfully these interests can be established in the parliament and society. ${ }^{7}$

The challenge for the relevant interest group involvement is that these groups can be difficult to identify. In 2010-2012, Estonia had an e-solution KYPO, ${ }^{8}$ a statistical profile of Estonian civil society, which compiled public data collected in the registers. While this is no longer available on the web, the problems that were topical during its creation continue to be relevant today:

- the quality of public data in the non-profit associations and foundations register is low;

- updating data on citizen's associations in the national register and the access to data for state authorities and their partners is legally and technically complicated, time-consuming and often costly;

- government officials have an obligation to involve the target groups of the national development plans and legislation in the decision-making process, but they do not have a tool for mapping and involving citizen associations;

- the public records of the registers and the organization for involving interest groups in the decision-making process by the ministries (including inclusion plans) are not connected, there is no register-based infrastructure for involvement nor common understanding of how to organize involvement as quickly as possible;

- Due to the relatively small size of Estonian society and the market, a registration-based involvement infrastructure of civic associations as an ITdevelopment and marketing, is unlikely to be sustainable without a support from the state budget;

- the state statistics related to civic associations, the cross-usage of registers and the development of e-services is complicated by the number of state authorities involved and the need for political co-operation between ministers. The government does not have a clear division of labor and responsibility. ${ }^{9}$

It is definitely necessary to improve the availability and quality of the data of non-profit associations and foundations register. Why not do so by creating a portal of civic associations similar to KYPO? The premise for such a portal is that it would be convenient for all parties and the information would be quickly accessible. It would definitely help to improve the situation, if it were unambiguously clear, who was responsible for organizing interest group involvement in case of shared areas.

\section{Initiation of Draft Legislation and Requirements for Formulation of Legal Provisions}

A draft law may be launched in a number of ways. The most common practice is to use the guidelines outlined in coalition agreements or guidance documents by the government. Additional impetus may come from the opinions of the Chancellor

7 Kaugia, S. Õigusteadvuse olemus ja arengudeterminandid [Essence of Legal Consciousness and Determinants of Development]. Tartu: Tartu Ülikooli Kirjastus, 2011, p. 66.

8 Kodanikuühiskonna portree [A portrait of civil society]. Available: http://www.delfi.ee/archive/ kodanikeuhenduste-andmed-koondati-portaali-kypo?id=63964323; www.kypo.ee [no longer available].

9 Kasemets, A., Dsiss, M., Lepp, Ü. Eesti kodanikuühiskonna statistilise portree ja kaasamistaristu idee [The idea of the statistical portrait and involvement of Estonian civil society]. Riigikogu Toimetised, No. 25, 2012, p. 123. 
of Justice and the Auditor General, initiatives of the members of the parliament or the need to implement an international convention. The starting points for the initiatives stem from a wider social debate. A proposal for amending a specific legal act is usually submitted by the ministry concerned through the initiative of the minister, the senior officials of the ministry or the initiative of the author of the amendment proposal.

The regulation for the drafting of an act is set out in HÕNTE Chapter 1, section 1, which contains the substantive requirements for the draft act, the structure of the draft and descriptions of the various types of regulations. In accordance with $\$ 2$, a draft act is prepared for legal regulation of social relationships of the same type, if there is no legal regulation or it is insufficient or not up to date. At this point, it is worth noting that the act is justified, when it is intended for legal regulation of the same type of social relationships. The coordination of the draft act is subject to the involvement obligation described in subsection 1(5) above.

The objective of HÕNTE is to contribute to the consideration of the vital needs and social reality in legislative drafting. The comprehensibility of regulation to those it addresses is heavily influenced by the text of the act, its format and structure. "Legal texts must be comprehensible and clear for those they address, in order to act as a medium for moral standards. This includes the language of the law, the structure of the norm and also the structure of the law. It should be noted that the language of the law, as the language of instruction, should be more precise than general language and such precision is provided to the legal language by specialist terminology" ${ }^{10}$ The relevant requirements are set out in Chapter 2, section 2, of the HÕNTE. Paragraph 15(1) establishes a general requirement to comply with the Estonian Literary Standard. Paragraph 2 lays down a fundamental principle: the use of languages must be clear, unambiguous and precise. In essence, this stipulates that the norm must be understandable to those addressed, and it must follow the legal style, which, among other things, should ensure simplicity, the accuracy, the uniform interpretation and the correct emphasis. This is a relevant requirement, which, nevertheless, is difficult to achieve. Simplicity comes with the risk of excessive generalization or the use of imprecise terms. At the same time, uniform interpretation and accuracy are often achieved through very complex wording. However, only the fulfillment of both requirements can ensure that those who are required to observe and comply with the norms, can also unequivocally understand them.

Additionally, it is also important a provision should be worded in compliance with the structure corresponding to the type of the legal provision. The corresponding requirement is also laid down in $\$ 16$ of the HÕNE. The structure of the provision plays an important role in interpreting the provision, when it is necessary to determine whether it is an imperative provision or a discretion provision. As a general rule, provisions with prescriptive, binding, justifying, prescriptive, and prohibitive wording are imperative. At the same time, one must take into account the purpose, the subject and how strict is the imperative to be expressed by the provision. In case of discretion provisions, it is important to clearly express the discretionary power of those addressed, and whether it

10 Narits, R., Merusk, K. Õiguse olemusest ja seaduse võimalustest [On the Essence of Law and Possibilities of Legislative Acts]. Riigikogu toimetised, No. 2, 2000. Available: http://www.riigikogu. ee/rito/index.php?id=11645 [last viewed 02.05.2018]. 
is discretion of decision or of choice. Discretion of decision allows choosing whether to apply a consequence or not, whereas discretion of choice allows for a greater decision-making power, that is, two or more legal consequences that the implementer of the provision can choose from, depending on the situation. In addition, the HÕNTE provides for a number of other provisions that contribute to the comprehensiveness of the texts of the law. For example, the requirement to avoid synonyms and different expressions for rendering one and the same idea $(\$ 15(2))$, regulations for the use of terms, loanwords $(\$ 17)$, abbreviations, brackets and symbols $(\$ 19)$, and requirements for the use of the word form in various cases. Thus, it can be said that HÕNTE provides a quite detailed regulation to ensure that a legal text would be comprehensible to its addressees.

State authorities responsible for the initial drafting of legislation should focus on transparent legislative drafting and develop opportunities for citizens, nongovernmental organizations and other interest groups to participate and influence the legislative process. The use of social information should continue to be promoted in legislation.

Social statistics, the results of economic information and sociological studies are a part of the information that can help the people involved in the legislative drafting process to take the comprehensive view of society as well as oblige the political elite to have considerations for the state and needs of the members on the lower levels of society. ${ }^{11}$

\section{Adoption of Legislation and Feedback to Legislative Drafting}

Adoption of the legislative act is the final step in creating a legislative act. The approval of the act gives it legal force and the implementation of the act is legally formulated. In Estonia, laws are passed by the Rigikogu, and minor legislative acts by other state and local government agencies. The adopted law shall be signed by the President of the Riigikogu and then submitted to the Office of the President by the Chancery of the Riigikogu for proclamation and final entry into force. Usually, the President proclaims the law, then the law is published in Riigi Teataja. Providing a good reason, the President of the Republic may decide to not proclaim the law passed by the Riigikogu and send it back to the Riigikogu for a new debate and decision. In case the Riigikogu passes the law returned by the President unchanged, the President shall either proclaim the law or request the Supreme Court to review the constitutionality of the law. The Supreme Court has the right, upon consideration of the President's request, to refrain from enforcing the law, otherwise the President must proclaim the law. The law enters into force on the tenth day after its publication in the Riigi Teataja, unless the law provides for a different term.

Feedback to legislative drafting should provide information on the success level of set objectives. On the one hand, it is reflected in social statistics (which societal changes actually took place as a consequence of these decisions; whether the decision was justified or not) and on the other hand, in public opinion, which describes the subjective reaction of society to what is happening. Negative reaction is mostly due to the fact that the objective may not have been in line with the

11 See more at Kenkmann, P. Sotsiaalne informatsioon seadusloome edendamise teenistuses: olukord ja ettepanekud [Social information at the service of law enforcement promotion: situation and suggestions]. Riigikogu Toimetised, No. 1, 2000, p. 139 jj. 
expectations of the people, and was instead put in place on the basis of one party's program or the perceptions of the group of officials who drafted the decision. ${ }^{12}$ Therefore, the reactions of the public should not be gauged post-production, and a structural and continuous research into society's expectations should be carried out instead. The interests of the stakeholders should be taken into account from the initial stages.

Various institutions and interest groups are involved in the legislative drafting process and an impact analysis is carried out to measure the relevant economic, administrative, environmental and social impacts. Documents prepared as a result of this assessment are a part of the draft and therefore must be included in the draft.

Aside from the natural aim to use politics to maximize their power for as long as possible, the ex-ante, during and ex-post impact assessment is an effective tool for quickly spotting vulnerabilities. ${ }^{13}$ It is, of course, natural that problems come to light quicker in the areas that receive more attention, which is why it is expedient to start looking for the problem areas, which could affect the selected approach negatively, already in the initial phases of the process. Clear and up-to-date legislation reduces costs for both the state and other entities, reducing bureaucracy and the number of court cases. Therefore, good legislation must be directed towards the right subject, consistent in time and generally understandable.

The deeper purpose for legislative drafts is to maintain or change the social behavior of the parties in desired direction. Therefore, it is important that the substantial objectives and impacts of the law are discussed as openly and publicly as possible, and the impact of the law on the public interests is assessed. The draft acts under debate in the Rigikogu are accessible to the public mainly through the media, and therefore the quality of draft acts affects the work of the Riigikogu as well as the attitudes towards the law and also the media coverage. ${ }^{14}$

The Riigikogu also has the right to put a draft Act or other national issue on a referendum. In such case, a decision is taken by the majority vote of the votes cast, and the President is obliged to promptly proclaim the law and the decision is binding to all state bodies. The last sentence of the provision, however, creates a controversial situation - if the draft act submitted to a referendum does not receive a majority of votes cast, the President must call of extraordinary elections. It has been argued that this requirement severely inhibits the willingness of the Riigikogu to submit draft acts for a referendum. ${ }^{15}$ History has also confirmed this opinion and after our restoration of independence, the only referendums we have had have been on the issues central to statehood. The referendum on independence was held on March 3, 1991, the Constitutional referendum on June 28, 1992, and the amendment of the Constitution on 14 September 2003 in connection with joining the European Union. The Riigikogu has used referendum only for issues predicted to receive the majority vote and avoided the need for extraordinary elections.

12 Avatud Eesti Ühiskonna Instituut. Demokraatia ja rahvuslikud huvid. Eesti ühiskond - 2005 [Estonian Institute for Open Society Research. Democracy and national interests. Estonian society - 2005] (Project report). Tallinn: Avatud Eesti Fond 2006, p. 65.

13 Radaelli, C. M. Regulating Rule-Making via Impact Assessment. Governance, Vol. 23, Issue 1. Wiley Periodicals: Hoboken, 2010, p. 91.

14 Kasemets, A. Seadusloome kvaliteedi ja mõjude hindamise probleeme [Legislative quality and impact assessment problems]. Riigikogu Toimetised, No. 4, 2001, p. 102.

15 Annus, T. Riigiõigus [Constitutional law]. Tallinn: Juura, 2006, pp. 56-57. 
As citizens of the European Union, Estonians have the opportunity to participate in the European Citizens' Initiative. ${ }^{16}$ It is an invitation to the European Commission to make legislative proposals in areas where the European Union has legislative competence (e.g., the environment, agriculture, transport or public health). The citizens' initiative must be supported by at least 1000000 citizens of the European Union residing in at least 7 Member States out of 28 Member States. The minimum number of signatories is required for all 7 Member States. Citizens' initiatives cannot be organized by organizations and associations. However, organizations can support initiatives, provided that they are conducted in a transparent manner. ${ }^{17}$ An official register of European Citizens' Initiatives has been set up for the management of initiatives and applications, which brings the information comfortably to the user through the online environment. In Estonia, the right to petition is regulated by the recent Response to Memoranda and Requests for Explanations and Submission of Collective Addresses Act ${ }^{18}$ and the Riigikogu Rules of Procedure and Internal Rules Act. ${ }^{19}$

The HÕNTE provides for cases where the legislative intent is not required. Paragraph 1(2) specifies the implementation of EU law, conclusion, amendment or termination of an international agreement, and the State Budget Act. It also defines the situations in which the legislative proceedings of the draft need to be urgent with good reason and no significant legislative changes or any other significant impact occurs when the draft act is passed as an act (paragraphs 1 and 5 , respectively). If the first cases are specific, the latter are clearly discretionary decisions.

In addition to the previously covered legislative intent, the HÕNTE also regulates the preparation of the concept of a draft act. The corresponding regulation is in paragraph 1(3) of the Rules and provides that if the content of the planned draft act is of fundamental significance in the Estonian legal system, the ministry concerned will, after the approval of the legislative intent and before laying down the provisions of the draft act, prepare the concept of the draft act, indicating the legal options. According to the memorandum, the concept is similar to the memorandum, which has explained the problem in great detail and assessed the impacts. The difference is that the concept is prepared before the draft and the explanatory memorandum, and this will prevent a situation where the fundamental disputes begin only at the draft proceedings stage.

However, what deserves attention in this precept, is the definition of 'fundamental significance'. The explanatory memorandum of the HÕNTE does not contain a description on how to determine when the changes have a fundamental significance and when they do not. It may be assumed that this refers to drafts, which bring about changes affecting target groups. In any case, it is on the discretion of the ministry concerned, as the initiator of the process.

16 Regulation of the European Parliament and of the Council No. 211/2011, February 16, 2011, on the citizens' initiative.

17 The European Citizens' Initiative. Basic facts. Available: http://ec.europa.eu/citizens-initiative/ public/basic-facts [last viewed 02.05.2018].

18 Märgukirjale ja selgitustaotlusele vastamise ning kollektiivse pöördumise esitamise seadus [Response to Memoranda and Requests for Explanations and Submission of Collective Addresses Act]. RT I, 25.10.2016, 16.

19 Riigikogu kodu- ja töökorra seadus [Riigikogu Rules of Procedure and Internal Rules Act]. RT I, 28.06.2016, 22 . 
It is important to emphasize that the Government of the Republic cannot establish rules of legislative drafting for the Riigikogu. Therefore, if a draft act is, pursuant to clause 90(1) 1)-3) of the Riigikogu Rules of Procedure and Internal Rules Act, introduced by a member of the Rigikogu, a faction of the Riigikogu or a committees of the Riigikogu, then such introduction procedure is subject only to the Technical Rules for Draft Legislation Submitted for Legislative Proceedings and the requirements of the Riigikogu Rules of Procedure and Internal Rules Act. The HÕNTE requirements for thorough ex-ante and ex-post analysis, inclusion, development of legislative intent or concept, are not applicable.

It is the opinion of the author that this regulation is problematic. If the rules on the lawmaking activities of government institutions (especially ministries) are established to help ensure the effectiveness of the law to be introduced through more in-depth preparation and involvement of the parties, then draft legislation initiated by members, factions or committees of the Rigikogu does not guarantee the equivalent quality at the regulatory level.

The problems arise, at least theoretically, for any legislative acts processed in the Riigikogu. If the draft submitted to the Riigikogu by the Ministry is prepared as thoroughly as possible, the justification or the impact assessment requirements are not applicable for the amendments made by the Rigikogu pursuant to the $\$ 99$ of the Riigikogu Rules of Procedure and Internal Rules Act. It is also likely that such amendments will not be properly explained in the explanatory memorandum, which may make it difficult to interpret them in the future.

\section{Summary}

To sum up, developing as fair and as effective legislation at a national level presupposes that the legislative drafting is targeted at society: before the legislation is written down and proclaimed, the legislators need to be familiar with the nature and needs of society, to analyze in depth to whom and why these laws are written. Only this will help to overcome the alienation between the people and the state and to increase the effectiveness of the law and increase the security of society.

The regulation of the Government of the Republic of Estonia on the Rules of Good Legislation and Legislative Technique (Hea õigusloome ja normitehnika eeskiri - HÕNTE), which applies to government agencies, establishes quite thorough rules on the preparation of draft legislation: the preparer of the draft has a duty to prepare a development plan, to carry out an impact analysis, to involve the affected target groups, to create a concept of the law. However, the Technical Rules for Draft Legislation Submitted for Legislative Proceeding of the Riigikogu contain only the language, structure and normative requirements for the draft. Thus, if a draft is initiated by a parliamentary faction, members, or a committee, there is no obligation to go through the preparation process described in HÕNTE.

In answering the question on whether today's Estonian law-making process and related requirements ensure the comprehensibility of law, and its compliance with social realities, and thus support the the effectiveness of the law, it can be argued that the rules established by HÕNTE help to achieve the above-mentioned objective, emphasizing not only the valid normative side, but also the discussion between the parties and the impact analysis. The rules of legislative technique also ensure at the level of government agencies and the Rigikogu, that the text of the law is understandable and subject to certain rules. 
However, as there are no such obligatory preliminary actions for drafts initiated by the Riigikogu members, factions or committees, it is unfortunately possible that laws prepared using the legislative process, in part will not coincide with social reality or the attitudes of society. According to the author, it is important to continue to improve the co-operation between social scientists and the legislator in order to prevent such cases by having the legislator collect social information and using it for the purpose of lawmaking, with the aim of creating laws that take social needs into account.

\section{Sources}

\section{Bibliography}

1. Annus, T. Riigiõigus [Constitutional law]. Tallinn: Juura, 2006.

2. Avatud Eesti Ühiskonna Instituut. Demokraatia ja rahvuslikud huvid. Eesti ühiskond - 2005 [Estonian Institute for Open Society Research. Democracy and national interests. Estonian society 2005] (Project report). Tallinn: Avatud Eesti Fond, 2006.

3. Kasemets, A. Seadusloome kvaliteedi ja mõjude hindamise probleeme [Legislative quality and impact assessment problems]. Riigikogu Toimetised, No. 4, 2001.

4. Kasemets, A., Dsiss, M., Lepp, Ü. Eesti kodanikuühiskonna statistilise portree ja kaasamistaristu idee [The idea of the statistical portrait and involvement of Estonian civil society]. Riigikogu Toimetised, No. 25, 2012.

5. Kaugia, S. Õigusteadvuse olemus ja arengudeterminandid [Essence of Legal Consciousness and Determinants of Development]. Tartu: Tartu Ülikooli Kirjastus, 2011.

6. Kenkmann, $P$. Sotsiaalne informatsioon seadusloome edendamise teenistuses: olukord ja ettepanekud [Social information at the service of law enforcement promotion: situation and suggestions]. Riigikogu Toimetised, No. 1, 2000.

7. Narits, R. Seadusloome regulatiivse ja õigusliku mõju hindamine [Legal and Regulatory Impact Assessment of Legislation]. Riigikogu Toimetised, No. 4, 2001.

8. Narits, R., Merusk, K. Õiguse olemusest ja seaduse võimalustest [On the Essence of Law and Possibilities of Legislative Acts]. Riigikogu Toimetised, No. 2, 2000.

9. Radaelli, C. M. Regulating Rule-Making via Impact Assessment. Governance, Vol. 23, Issue 1. Wiley Periodicals: Hoboken, 2010.

10. Regulation of the European Parliament and of the Council No. 211/2011, February 16, 2011, on the citizens' initiative.

\section{Normative Acts}

1. Hea õigusloome ja normitehnika eeskiri [Rules for Good Legislative Practice and Legislative Drafting]. RT I, 29.12.2011, 228.

2. Märgukirjale ja selgitustaotlusele vastamise ning kollektiivse pöördumise esitamise seadus [Response to Memoranda and Requests for Explanations and Submission of Collective Addresses Act]. RT I, 25.10.2016, 16.

3. Riigikogu kodu- ja töökorra seadus [Riigikogu Rules of Procedure and Internal Rules Act]. RT I, 28.06.2016, 22.

4. Riigikogus menetletavate eelnõude normitehnika eeskiri [Technical Rules for Draft Legislation Submitted for Legislative Proceedings]. Available: https://www.riigikogu.ee/wpcms/wp-content/ uploads/2014/11/Riigikogus-menetletavate-eeln-ude-normitehnika-eeskiri.pdf [last viewed 02.05.2018].

5. Vabariigi Valitsuse reglement [Rules of the Government of the Republic]. RT I, 29.12.2011, 233.

\section{Other Sources}

1. Kaasamise hea tava [The Good Practice of Engagement]. Available: https://riigikantselei.ee/et/ kaasamise-hea-tava [last viewed 02.05.2018].

2. Kodanikuühiskonna portree [A portrait of civil society]. Available: http://www.delfi.ee/archive/ kodanikeuhenduste-andmed-koondati-portaali-kypo?id=63964323; www.kypo.ee [no longer available].

3. The European Citizens' Initiative. Basic facts. Available: http://ec.europa.eu/citizens-initiative/ public/basic-facts [last viewed 02.05.2018]. 


\title{
Implementation of the Concept of 'Public Assets' in the Latvian Legal System
}

\author{
Dr. iur. Edvīns Danovskis \\ Faculty of Law, University of Latvia \\ Docent at the Department of State Law \\ E-mail: edvins.danovskis@lu.Iv
}

\begin{abstract}
The article analyses the problems of division between public and private legal relationships regarding the use of assets owned by public entities. Although most of the assets owned by public entities are managed within the framework of private legal relationships, some assets which are allocated for public use are treated as 'public assets', like rivers, the sea, public parks etc. The legal relationships arising out of the use of those assets are public legal relationships, reviewed by administrative courts in case of a dispute. The concept of 'public assets' has been implemented in the Latvian legal system from the German administrative law (Offentliche Sache). However, literal transplantation of the German concept has caused irregularities with the existing practices. Therefore, by case studies it is argued that a narrower approach should be used regarding the concept of public assets.
\end{abstract}

Keywords: public assets, subjective public rights, ports, forests, ownership.

\section{Contents}

Introduction ................................ 172

1. Background and Origins of the Term 'Public Asset' in Latvian Legal System . . . . . . . 173

2. Two Examples of Case Studies . . . . . . . . . . . . . . . . . . . . . . . . . 176

3. True and Safe Contents of the Public Assets Concept . . . . . . . . . . . . . . . . . . . 179

Summary. . . . . . . . . . . . . . . . . . . . . . . . . . . . . . . . . . 181

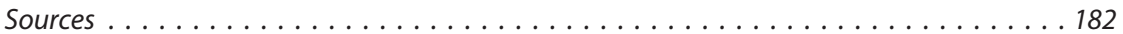

Bibliography ................................ 182

Normative Acts . . . . . . . . . . . . . . . . . . . . . 182

Case Law . . . . . . . . . . . . . . . . . . . . . . . . . . . 182

\section{Introduction}

Inspiring concepts and successful practices of other legal systems are important factors influencing development of domestic legal system. The Latvian legal system has successfully transplanted several basic concepts of German administrative law, like the concept of public legal entity and several important features of administrative procedure law, most notably, the concept of administrative act (Verwaltungsakt). These concepts successfully thrived and become beautiful, 
self-dependent 'plants' in their development and doctrinal understanding although there are many similarities with the legal system of their origin, there are also many well-grounded differences and national peculiarities. ${ }^{1}$ The Latvian experience of transforming administrative law in a sound and well-developed legal system is a unique success story and a valuable source of inspiration for other postsoviet states.

However, not all efforts to implement foreign legal concepts have been as successful. A rather novel and controversial issue even in the country of its origin is the concept of 'public assets' (Offentliche Sache) originally developed in the German legal system. In general, the concept of public assets concerns issues regarding public use of various assets owned or otherwise supervised by the public entities. The legal questions arising out of this concept include subjective public rights of private persons to use these assets and setting the disputes arising out of legal relationships regulating these assets.

The purpose of this article is to explain the ways in which the concept of public assets has been introduced in the Latvian legal system and legal problems arising out of this concept. The Latvian experience regarding this issue may be useful for other states where administrative courts have been established and where a consequential need to divide public and private legal relationships arises. For the national legal auditorium, this article provides guidelines for further development of the concept of public assets and propositions for a narrow approach to this concept.

\section{Background and Origins of the Term 'Public Asset' in Latvian Legal System}

Legal entities of public law (the State, local governments etc., hereinafter - public entities) own vast amount of movable and immovable assets: land, buildings of various kinds (living premises, warehouses, office buildings etc.), cars, computers, furniture etc. These objects are property in the sense of the Civil Law and are thus regulated by the Civil Law. 'State property', 'local government property' or 'private property' are more economic than legal terms, for in the sense of property law all owners are equal in the use of their rights. [..] The owner has an absolute right to his property." 2 Of course, the law also provides limits to the freedom of use of property, however, within this framework, the owner is entitled to use the property according to his own will. Therefore, legal relationships arising from the use or intention of use of property, including the property owned by public entities, usually are private legal relationships - the disputes arising out of property law are therefore dealt as private legal disputes and are not subject to judicial review in administrative courts, because public entities do not have any special public prerogatives (public power) regarding their property.

There are some laws, which provide several restraints on public entities regarding their ownership, most notable of them are the Law "On the Alienation of the

1 See Briede, J., Danovskis, E. Administrative Law and Procedure. In: The Law of the Baltic States. Ed. by T. Kerikmae, K. Joamets, J. Pleps, A. Rodina, T. Berkmanas, E. Gruodyte. Springer, 2017, p. 204.

2 Balodis, K. Ievads civiltiesībās [Introduction in the Civil Law]. Riga: Zvaigzne ABC, 2007, p. 34; on ownership as an absolute right see also Commentary of the article 927 of the Civil law: Grütups, A., Kalniņš, E. Civillikuma komentāri. Trešā daḷa. Lietu tiesības. İpašums [Commentary of the Civil Law. Part Three. Property Law]. $2^{\text {nd }}$ revised edition. Rīga: Tiesu namu ağentūra, 2002, pp. 16-18. 
Property Owned by a Public Entity" 3 and the Law "On Prevention of Squandering of the Financial Resources and Property of a Public Person". ${ }^{4}$ The Law "On the Alienation of the Property Owned by a Public Entity" prescribes conditions under which a property belonging to a public person may be alienated to other public person or a private person, types of alienation (sale, exchange, alienation without compensation etc.) and procedures of alienation. The Law "On Prevention of Squandering of the Financial Resources and Property of a Public Person" provides a general obligation to use a property owned by a public entity rationally and in accordance with the law. It stipulates various prohibitions (for instance, a general prohibition to transfer a public entity's property for use to private person without compensation, a prohibition to donate property of a public entity) and procedures (for instance, on lease of a property owned by a public entity). These two main laws generally regulate the 'internal rules' of the government in managing its properties and they are not supposed to grant subjective rights for private persons to use or control the management of property owned by public persons. Since many of the rules are of technical and rather casuistic nature, and since the management of property is mostly a question of rationality, the legal provisions regulating these issues, as well as application of those laws has not achieved any significant interest from the legal scholarship. The respective rules are important mainly for those working in the government and infringements of these rules may cause disciplinary and criminal actions.

Since the establishment of administrative courts in 2004, there has been a consistent case law that decisions of public entities regarding their property are adopted in the sphere of private law. If a private entity submits a request to buy a property owned by a public entity, the denial to satisfy this request cannot be reviewed by administrative courts, because the public entity acts as any other owner, which does not want to alienate its property. ${ }^{5}$ The same has been ruled regarding submissions of a private persons to conclude lease agreements on lease of a property (land area or premises) owned by a public entity. ${ }^{6}$

However, since 2007 the Department of Administrative Cases of the Supreme Court has ruled that some objects owned by public entities should be treated as 'public assets' and therefore some decisions regarding the use of those assets are

3 Publiskas personas mantas atsavināšanas likums [Law on Alienation of Assets of a Public Entity]. Latvijas Vēstnesis, No. 168(2743), 2002.

4 Publiskas personas finanšu līdzekḷu un mantas izšḳērdēšanas novēršanas likums [On Prevention of Squandering of the Financial Resources and Property of a Public Person]. Latvijas Vēstnesis, No. 114(397), 1995.

5 See Decision of the Department of Administrative Cases of the Supreme Court of 25 August 2008 in case No. SKA-574/2008, pp. 11-12. In: Latvijas Republikas Augstākās tiesas Senāta Administratīvo lietu departamenta spriedumi un lēmumi 2008. Rīga: Tiesu namu ağentūra, 2009, pp. 473-480; Decision of the Department of Administrative Cases of the Supreme Court of 11 Jaunary, 2018 in case No. 727/2018. Available: http://at.gov.lv/downloadlawfile/5441 [last viewed 13.06.2019]; Decision of the Department of Administrative Cases of the Supreme Court of 16 October 2018 in case No. SKA1515/2018. Available: https://manas.tiesas.lv/eTiesasMvc/nolemumi/pdf/365429.pdf [last viewed 13.06.2019].

6 Decision of the Department of Administrative Cases of the Supreme Court of 2 October 2018 in case No. 1247/2018. Available: https://manas.tiesas.lv/eTiesasMvc/nolemumi/pdf/364173.pdf [last viewed 13.06.2019]; Decision of the Department of Administrative Cases of the Supreme Court of 19 April 2018 in case No. 949/2018. Available: https://manas.tiesas.lv/eTiesasMvc/nolemumi/pdf/351712. pdf [last viewed 13.06.2019]; Decision of the Department of Administrative Cases of the Supreme Court of 11 July 2014 in case No. 874/2014. Available: https://manas.tiesas.lv/eTiesasMvc/nolemumi/ pdf/357212.pdf [last viewed 13.06.2019]. 
administrative acts (subject to judicial review). The first decision of this kind was adopted regarding ports. Ventspils Port Authority - a public entity - owns docks in the Ventspils Port. A lease contract between Ventspils Port Authority and a private company on a lease of a dock was concluded. The contract, inter alia, designated provisions regarding payment of rent, and stated that the Ventspils Port Authority may unilaterally set the amount of rent payment. The private company objected to the decision of Ventspils Port Authority to increase rent payment and claimed in administrative court to annul the respective decision. Initially, the administrative court refused to initiate a case, because in the view of the court the agreement and dispute had a purely private law nature. However, the Supreme Court adopted a novel approach and concluded that "the Ventspils Port as an important object of national economy has been established to satisfy public interests. Therefore [..] the Ventspils Port is a public asset and therefore its operation is regulated by the law of public assets." 7 Hence, the agreement was treated as a contract of public law (administrative contract).

Since then, the concept of public assets in the decisions of the Supreme Court has been attributed to a public square in a city ${ }^{8}$, bus station ${ }^{9}$, airport ${ }^{10}$ (all three in disputes between a taxi driver and a company operating bus station / the national airport to remove a traffic sign allowing access to driveway in front of the central station/bus station / airport to only some taxi companies), cemetery (a dispute between a local government and a private person regarding rent payments for a grave space) ${ }^{11}$, park owned by a university (dispute between the university and a private person regarding refusal to allow trade in the park $)^{12}$ and several other objects (roads, etc.).

The Supreme Court has transplanted the concept of 'public assets' in the case law from the German concept of 'public assets' (Offentliche Sache). In Germany, the concept of public assets is one of the most ambiguous concepts of Administrative Law. On the one hand, the concept of public assets has been traditionally outlined in textbooks on general administrative law as a particular branch of administrative law dealing with the use of public assets for the benefit of public good. Public assets are usually divided in assets for inner use of the government (includes government buildings and their inventory, police cars etc.) and public assets for public use, which comprise buildings intended for use of private persons (schools, public libraries, museums, theatres, hospitals, stadiums etc.) and objects that according to their nature are intended for public use, like public streets, public

Decision of the Department of Administrative Cases of the Supreme Court of 26 January 2007 in case No. SKA-78/2007. In: Latvijas Republikas Augstākās tiesas Senāta Administratîvo lietu departamenta spriedumi un lēmumi 2007. Rīga: Tiesu namu agentūra, 2008, p. 543.

8 Decision of the Department of Administrative Cases of the Supreme Court of 22 February 2010 in case No. 101/2010. Available: http://at.gov.lv/downloadlawfile/4747 [last viewed 13.06.2019].

9 Decision of the Department of Administrative Cases of the Supreme Court of 10 February 2017 in case No. 808/2017. Available: http://at.gov.lv/downloadlawfile/718 [last viewed 13.06.2019].

10 Judgment of the Department of Administrative Cases of the Supreme Court of 23 March 2017 in case No. 470/2017. Available: http://at.gov.lv/downloadlawfile/5530 [last viewed 13.06.2019].

11 Decision of the Department of Administrative Cases of the Supreme Court of 20 November 2015 in case No. 1427/2015. Available: http://at.gov.lv/downloadlawfile/4335 [last viewed 13.06.2019].

12 Decision of the Department of Administrative Cases of the Supreme Court of 27 July 2016 in case No. 1190/2016. Available: http://at.gov.lv/downloadlawfile/5148 [last viewed 13.06.2019]. 
air space, rivers and other public waters. ${ }^{13}$ The concept of public assets should not be understood as an opposite to ownership in private law, but rather as a set of particular rules regulating the use of assets available for public use. ${ }^{14}$ On the other hand, as the notable German legal scholar, Prof. Ulrich Stelkens has written, the concept of public assets has recently been omitted in several textbooks on general administrative law due to the considerable uncertainties concerning its scope and content. ${ }^{15} \mathrm{He}$ argues that there are no general rules on 'public movable assets'. ${ }^{16}$ The law on public assets is something more than a mixture of rules on borderline between the public and private law, because the main legal questions around this issue deal with construction, use and maintenance of public infrastructures of the government. ${ }^{17}$ Although the Latvian legal scholarship has attempted to implement the concept of public assets from the German law ${ }^{18}$ several times, it appears that transplantation of a legal concept vague: even in the country of its origin it has created a result contrary to the essence of law, yielding uncertainty and superficiality. As has been generally observed, the doctrine of the public assets in Latvia is underdeveloped and the use of the foreign doctrine can be used only in a limited scope due to differences of the legal regulation. ${ }^{19}$

The next chapter analyses two particular examples of how a premature and even superficial use of the concept of 'public assets' has created legal uncertainties and irregularities within the existing legal practices.

\section{Two Examples of Case Studies}

\section{Ports as Public Assets}

As has been mentioned earlier in this article, the first case in which the Supreme Court used the term 'public asset' was heard in 2007 regarding ports. The respective decision ruled that the port is a public asset and therefore an agreement between the port authority and a private company regarding the lease of a dock owned by the port authority is regulated by the law on public assets and therefore lies under the jurisdiction of administrative courts. Such approach was later used in one other court ruling regarding commercial activities in the ports. ${ }^{20}$ In this ruling, the court

13 See, for instance, Wolff, H., Bachof, O., Stober, R. Verwaltungsrecht. Band 2. München: Verlag C. H. Beck, 2000, S. 682-686; Paine, F. J. Vācijas vispārīgās administratīvās tiesības. Vācijas Administratīvā procesa likums [German General Administrative Law. German Federal Administrative Procedure Law]. Rìga: Tiesu namu ağentūra, 2002, pp. 415-425.

14 Wolff, H., Bachof, O., Stober, R. Verwaltungsrecht. Band 2. München: Verlag C. H. Beck, 2000, S. 679.

15 Stelkens, U. Das Recht der Offentlichen Sachen: Allgemeines Verwaltungsrecht, Besonderes Verwaltungsrecht, Trümmerhaufen - oder was? Die Verwaltung, Band 46, Heft 4, 2013, S. 493.

16 Ibid., S. 507-508.

17 Ibid., S. 535.

18 See, for instance, textbook on administrativelaw Briede, J., Danovskis, E., Kovalevska, A. Administratīvās tiesības. Mācību grāmata [Administrative Law. Textbook]. Rīga: Tiesu namu aǵentūra, 2016, pp. 232-247; Jambuševa, L. Ielas kā publiskas lietas statuss un tās parastā lietošana [Street as a public asset and its ordinary use]; Jurista Vārds, No. 38(890), 2015; Briede, J. Publisko lietu seviškāā lietošana [Particular Usage of Things for Public Use]. In: Tiesību efektīvas piemērošanas problemātika. Latvijas Universitātes 72. zinātniskās konferences rakstu krājums. Rīga: LU Akadēmiskais apgāds, 2014, pp. 211-318.

19 Saulītis, E. Publisko personu īpašums un īpašuma realizācijas formas. Promocijas darbs [Public person's property and property rights]. Rīga: Biznesa augstskola "Turība", 2016, p. 40. Available: http:// www.turiba.lv/f/Promocijas_darbs_E_Saul itis.pdf [last viewed 13.06.2019].

20 Decision of the Department of Administrative Cases of the Supreme Court of 3 May 2011 in case No. SKA-482/2011. Available: http://www.at.gov.lv/downloadlawfile/4615 [last viewed 13.06.2019]. 
explained that "the term 'public asset' means an asset with a special status of its use provided by provisions of public law norms". This statement was supported with a reference to a German Administrative law textbook of professor Franz-Joseph Peine translated in Latvian. ${ }^{21}$

Unfortunately, the conclusion that a port is a public asset was too vague and superficial. The port territory consists of various objects - waterway, navigation facilities, docks, land areas used for different purposes (warehouses, cafeterias, living premises etc.). It is clear that some of these objects are exclusively governed by the port authority - aquatorium, waterway, navigation facilities, etc. Therefore, decisions of the port authority regarding availability and use of those facilities are adopted in the sphere of public law, i.e., they are manifestation of the public power. However, land area and docks are not exclusively governed by the port authority. Article 4, part one of the Law on Ports ${ }^{22}$ states that land area in the port may be owned by either the state, local government or other legal of physical person. Part four of the same article prescribes that docks may be owned not only by the state and local government, but by other legal or physical persons as well. Therefore, according to the law, docks are a property that can be owned either by a public entity or by a private person. Most of the docks are owned by the state and these docks according to the part five of the Law on Ports are in the possession of the port authority which "may rent or lease the land owned by the State or a local government, or encumber it with easements for the purpose of constructing buildings and structures, surface and underground communications systems, or in order to perform other economic activities, particularly with respect to the right of use or right of use for construction. In such transactions a port authority shall act on behalf of land owners." Consequently, the port authority does not use an exclusive (public) right, but acts merely as any other owner of a dock. In practice, a long-term lease contracts are concluded on a lease of a dock - the private company usually invests huge resources to develop and maintain a dock for specific operations - reloading and storage of various chemicals, coal, timber etc. The accessibility of these docks for freight operations is dependent upon private transaction between the company renting or owning the dock and the company using the ship.

It should be rather clear that according to the law docks in the port are property owned by both public and private entities. Public entities have entrusted their property for economic development to the port authority. Therefore, there is no logical nor legal reason why the legal relationships between owner of the dock and renter of the dock should be considered as public legal relationships. Consequently, in 2013 the Parliament amended the Law on Ports by stating that the collection of rent payments is an activity performed by the port authority in the private sphere. Even before that, the law clearly stated that the port authority acts in the private sphere when it "manages the property owned or transferred to its possession [..] docks [..]". Afterwards, the Supreme Court had to change its case law and concluded that now the legislator has clearly stated that the agreement between the port authority and a private company regarding the rent of a dock is a private law contract, and therefore disputes arising out of it are private law disputes not

21 Paine, F. J. Vācijas vispārīgās administratīvās tiesības. Vācijas Administratīiā procesa likums [German General Administrative Law. German Federal Administrative Procedure Law]. Rīga: Tiesu namu ağentūra, 2002.

22 Likums par ostām [Law On Ports]. Latvijas Vēstnesis, No. 80(211), 1994. 
under the jurisdiction of administrative courts. ${ }^{23}$ However, the Supreme Court has still consistently reminded that "in choosing a person with whom to conclude the rent contract the port authority as a public entity is not entirely free, because the port is a public asset and the decision on the person with whom to conclude a lease agreement is adopted in the public sphere." ${ }^{24}$ Again, the argument about the port as a public asset is superficial, because the legal regulation on objects in the port is more complex and clearly states that all activities regarding docks are in the domain of private sphere and therefore free of burdens posed by the principles of public law. This example clearly shows the dangers of vague legal reasoning and uncritical transplantation of general examples in the textbooks on a foreign legal system in a current legal reality of another state.

\section{Forests as Public Assets}

A recent 'alarm bell' regarding erroneous use of the concept of public assets has been adopted in a case regarding a decision of a local government to agree to exchange land - a land area partially covered with forest owned by the local government and other area owned by a private person. The council of the local government adopted a decision in which it generally agreed to conclude a respective agreement and set preconditions for conclusion of such an agreement. This decision was contested in the administrative court by a third person - an environment protection association. The judge of administrative court refused to initiate proceedings because the contested decision was directed towards conclusion of private legal relationships and therefore according to consistent case law it was not an administrative act (not subject for judicial review in administrative courts). The Supreme Court ruled that the contested decision was not adopted in the sphere of private law. Supreme Court ruled that a forest owned by the local government is a public asset, because according to the Forest Law it is publicly available to everyone. With the reference to aforementioned book of German professor Franc-Joseph Peine, the Supreme Court concluded that a decision terminating public use of public asset is administrative act - "in this regard, there is no reason in Latvia to look differently towards thesis of the doctrine of public assets developed in the German Administrative law scholarship where termination of the use of a public asset is treated as an administrative act." ${ }^{25}$

The argumentation in this decision is false in two aspects. The first aspect concerns the reference to the German administrative law supporting the statement that a decision to terminate the status of a public asset is an administrative act such a statement simply cannot be found in the respective reference. The page mentioned in the reference begins a chapter titled "Termination of allotment" (in German: die Widmung) and contains a short general statement that termination of allotment is made in the same way as establishment of allotment. The chapter

23 Decision of the Department of Administrative Cases of the Supreme Court of 16 January 2018 in case No. SKA-825/2018. Available: http://www.at.gov.lv/downloadlawfile/5420 [last viewed 13.06.2019].

24 Ibid., para. 7.

25 Decision of the Department of Administrative Cases of the Supreme Court of 30 January 2018 in case No. 838/2018, para. 8. Available: https://manas.tiesas.lv/eTiesasMvc/nolemumi/pdf/346942.pdf [last viewed 13.06.2019] - this text in the decision is based on a ference to the following work: Paine, F. J. Vācijas vispārīgās administratīvās tiesības. Vācijas Administratīvā procesa likums [German General Administrative Law. German Federal Administrative Procedure Law]. Rīga: Tiesu namu agentūra, 2002, p. 434. 
next explains termination of allotment of public roads. ${ }^{26}$ In Germany rights to enter a forest for recreational purposes is prescribed by article 14 of the Federal Forest Law. ${ }^{27}$ The respective article grants the right to enter a forest for recreational purposes irrespective of whether a forest in owned by a public person or private person. However, article 14, paragraph two stipulates that German Federal Lands are entitled to prescribe details and restriction regarding that right. In German legal literature, forests are treated as public assets only insofar as the law grants their public availability. ${ }^{28}$

The second aspect is the ignorance of allotment regulation in the Forest $\mathrm{Law}^{29}$. Article 5, part one of the Forest Law states that every physical person is entitled to free movement in forests owned by the state or local municipality. Article 16, part three of the Forest Law states that physical persons are entitled to gather fruits, mushrooms and other products of a forest owned by the state or local municipality. In this regard, the law prescribes general availability of forests owned by state or local municipalities. If a forest is owned by a private person, then that owner is entitled to limit availability of the forest (article 5, part two of the Forest Law). Therefore, the public availability of a forest for public use is dependent only upon a single legal criterion - ownership. The availability (allocation) of the forest for public use therefore is provided only by the law itself, and not a decision to conclude contracts of exchange, sale etc. Consequently, the decision if and how a public entity acquires or disposes of its forests does not include use of state power and therefore is not subject for judicial review. In the present case, the argument of Supreme Court regarding forest as a public asset was expressed obiter dictum, i.e., luckily the Supreme Court concluded that the claimant did not have subjective rights to contest the decision of the local government.

This example illustrates that a careless reference to the German legal literature can lead to superficial results. Although generally the Forest Law grants rights to free access and use of the forest, it is indeed rather hard to imagine how in the use of these rights the concept of public asset could be of importance.

\section{True and Safe Contents of the Public Assets Concept}

The approach and cases introducing the concept of 'public assets' in the Latvian legal system has been severely criticized before, even as far as stating that "the argumentation of several decisions of the Supreme Court regarding public assets raises doubt whether they correspond to the legal regulation and the will of the legislator." ${ }^{30}$ However, the occurrence of this subject in administrative law in some ways is inevitable, because it is a logical consequence of division between public legal relationships and private legal relationships.

The division of public and private legal relationships depends upon a following criterion: if a public person adopts a decision that, according to legal provisions, in

26 Paine, F. J. Vācijas vispārīgās administratīvās tiesības. Vācijas Administratīvā procesa likums [German General Administrative Law. German Federal Administrative Procedure Law]. Rīga: Tiesu namu aǵentūra, 2002, p. 434.

27 Gesetz zur Erhaltung des Waldes und zur Förderung der Forstwirtschaft. Available: https://www. gesetze-im-internet.de/bwaldg/BJNR010370975.html [last viewed 13.06.2019].

28 Wolff, H., Bachof, O., Stober, R. Verwaltungsrecht. Band 2. München: Verlag C. H. Beck, 2000, S. 681.

29 Meža likums [Forest Law]. Latvijas Vēstnesis, No. 98/99(2009/2010), 2000.

30 Saulītis, E. Publisko personu īpašums un īpašuma realizācijas formas. Promocijas darbs [Public person's property and property rights]. Rīga: Biznesa augstskola "Turība", 2016, p. 39. Available: http:// www.turiba.lv/f/Promocijas_darbs_E_Saulitis.pdf [last viewed 13.06.2019]. 
similar situation could also be made by a private person, then the public person does not use the state power. ${ }^{31}$ Indeed, the state power - exclusive rights by their nature is the only safe legal criterion to determine which actions of a public person should be treated as public legal relationships and therefore subject to judicial review in administrative courts and which - as ordinary private legal relationships or a simple management of one's own property. In this regard, it is obvious that there are objects which, according to their nature or legal provisions, are in exclusive management of a public person, like public roads, rivers, air space, the sea and seaside, parks owned by local governments, collection of the National Library etc. There are two cumulative criteria with a practical significance to mark an object as a public asset:

1) the object according to its nature or legal provisions is in an exclusive management or supervision of a public entity;

2) the object has been allocated to a public (common) use.

Only these criteria may rise legally relevant issues to be decided by the administrative courts, namely, disputes regarding designating these assets for special use (permissions to use streets for souvenir trade, permission to organise fireworks on a river, etc.) and disputes regarding equal availability to those objects.

Objects used for purposes of government tasks should not be included in this concept, because most of them by their nature may also be used for other purposes. For instance, sometimes public schools have been considered as 'public assets'32. Although the school premises are used for performing government tasks (public education), the building as such contains premises just like any other building - it has corridors, rooms with doors and windows, etc. The local government, which usually owns the building, may use it for different purposes as well, for instance, to lease a part of those premises for a private company to establish cafeteria or the school hall for dance lessons on Sundays. Disputes regarding the availability of those premises for lease should not be considered as public-law disputes, because the local government manages these premises as any other owner of a property when it is not used for educational purposes. It is merely a matter of efficiency and usefulness for the owner to decide whether the premises should or should not be leased to private persons for other purposes. This is more evident in the case when the school building itself does not belong to the local government but a part of it is leased from a private entity.

An example with the National Library may also be useful to explain the necessity of distinction between various kinds of objects owned by the state. According to the Law on National Library, "the collection of the National Library of Latvia and databases are generally accessible State property." 33 Therefore, according to the law, the issues regarding use and accessibility to the collection of

31 This criterion has been widely used both in the legal doctrine (Briede, J., Danovskis, E., Koval̦evska, A. Administratīvās tiesības. Mācību grāmata [Administrative Law. Textbook]. Rīga: Tiesu namu ağentūra, 2016, p. 25; Danovskis, E. Publisko un privāto tiesību dalïjuma nozīme un piemērošanas problēmas Latvijā [Importance and Problems of Application of Public-Private Law Divide in Latvia]. Rìga: Latvijas Vēstnesis, 2015, p. 241) and case law (see, for instance, Judgment of Department of Civil Cases of the Supreme Court of 28 February 2017 in case No. SKC-49/2017, para. 9. Available: https://manas.tiesas.lv/eTiesasMvc/nolemumi/pdf/301014.pdf [last viewed 13.06.2019]; Decision of the Department of Administrative Cases of the Supreme Court of 16 October 2018 in case No. SKA-1515/2018, para. 7. Available: https://manas.tiesas.lv/eTiesasMvc/nolemumi/pdf/365429. pdf [last viewed 13.06.2019]).

32 Briede, J., Danovskis, E., Kovaļevska, A. Administratīvās tiesības. Mācību grāmata [Administrative Law. Textbook]. Rīga: Tiesu namu aǵentūra, 2016, p. 233.

33 On the National Library of Latvia. Article 3, part 1. Ziņotājs, No. 1/2, 1993. 
the library are performed within the sphere of public law. However, if the library for some reason refuses access to the collection of the library (for instance, because the person has breached library rules) then the dispute can be resolved without any reference to the concept of 'public assets'. It is obvious that accessibility and use of the collection of the library is within the realm of government's tasks and that the state manages this property not as any other owner. However, accessibility to other premises of the National Library building, for instance, conference hall, are not as such allocated for public use, therefore decisions regarding availability of those premises are of purely private nature. It would be quite wrong to state that 'library is a public asset' without specifying to which part or use of the 'library' (i.e., collection, building, etc.) this expression is attributed.

Consequently, in future development of case law regarding disputes on the use of public assets it is very important not to use generalizations or examples from another legal system, because legal regulation and details are of utmost importance in determining whether the use of an asset constitutes the use of public power or is merely a management of property. It is also doubtful whether a concept of 'law on public assets' should be separated as a distinct branch of administrative law, since there are very few common principles regarding the use of public assets. From the doctrinal point of view, the 'law on public assets' in textbooks is mostly descriptive accounts on the meaning and types of public assets, types of allocation for public use and types of use of public assets. However, when one looks closer into legal regulation of particular public assets, a very complex picture is revealed. A notable German law professor Hartmut Maurer explains omission of chapter on public things in his classical work on General Administrative Law by stating that "this area for students is most actual within the context of road laws which usually is dealt within the special part of administrative law." 34 Therefore, although the concept of public assets undeniably exist in the Latvian legal system and is a consequence of use of public power towards several assets available for public use, it implies so few general legal consequences that for the time being it does not form a unified system of legal rules regulating the use of these assets.

\section{Summary}

1. The concept of public assets in Latvia is a consequence of division between the public and private law. If an asset according to its nature or legal provisions is in an exclusive management or supervision of a public entity and the object has been allocated to a public (common) use, then legal relationships regarding the public use of the asset by private persons are public legal relationships, i.e., disputes are resolved in the administrative courts in accordance with the principles of public law.

2. The development of the public assets concept has been elaborated in the case law of the Department of Administrative Cases of the Supreme Court in the past 10 years. The concept has clearly been derived from the German administrative law, where the debate regarding its scope and system is still ongoing. Overly literal approach adhering to the German concept of public assets and vague generalizations have led to inconsistencies with the existing legal practices and law, which have treated the lease and sale of several

34 Maurer, H. Allgemeines Verwaltungsrecht. 17. Auflage. München: Verlag C. H. Beck, 2009, S. VIII. 
properties, including docks in the ports and forests owned by public entities as activities within the realm of private law.

3. Since the practical effect of the public assets concept is to determine whether and how private persons are entitled to use public assets, and since the right to use public assets is completely dependent upon legal acts providing allocation of public use, in further case law a particular attention should be devoted to scope and content of allocation (subjective rights to use the asset) and determining whether the allocation of the asset to public use is a manifestation of public power (exclusive rights to manage the asset).

\section{Sources}

\section{Bibliography}

1. Balodis, K. Ievads civiltiesībās [Introduction to Civil Law]. Rīga: Zvaigzne ABC, 2007.

2. Briede, J. Publisko lietu sevišķā lietošana [Particular Usage of Things for Public Use]. In: Tiesību efektīvas piemērošanas problemātika. Latvijas Universitātes 72. zinātniskās konferences rakstu kräjums. Rīga: University of Latvia Press, 2014, pp. 211-318.

3. Briede, J., Danovskis, E., Kovaļevska, A. Administratīvās tiesības. Mācību grāmata [Administrative Law. Textbook]. Rīga: Tiesu namu ağentūra, 2016.

4. Danovskis, E. Publisko un privāto tiesību dalījuma nozīme un piemērošanas problēmas Latvijā [Importance and Problems of Application of Public-Private Law Divide in Latvia]. Rīga: Latvijas Vēstnesis, 2015.

5. Grūtups, A., Kalniņšs, E. Civillikuma komentāri. Trešā daḷa. Lietu tiesības. Īpašums [Commentary of the Civil Law. Part Three. Property Law]. $2^{\text {nd }}$ revised edition. Rìga: Tiesu namu aǵentūra, 2002.

6. Jambuševa, L. Ielas kā publiskas lietas statuss un tās parastā lietošana [Street as a Public Asset and its Ordinary Usage]. Jurista Värds, No. 38(890), 29.09.2015.

7. Maurer, H. Allgemeines Verwaltungsrecht. 17. Auflage. München: Verlag C. H. Beck, 2009.

8. Paine, F. J. Vācijas vispārīgās administratīvās tiesības. Vācijas Administratīiā procesa likums [German General Administrative Law. German Federal Administrative Procedure Law]. Rīga: Tiesu namu ag̀entūra, 2002.

9. Saulìtis, E. Publisko personu īpašums un īpašuma realizācijas formas. Promocijas darbs [Public person's property and property rights]. Rīga: Biznesa augstskola "Turìba", 2016. Available: http:// www.turiba.lv/f/Promocijas_darbs_E_Saulitis.pdf [last viewed 13.06.2019].

10. Stelkens, U. Das Recht der Offentlichen Sachen: Allgemeines Verwaltungsrecht, Besonderes Verwaltungsrecht, Trümmerhaufen - oder was? Die Verwaltung, Band 46, Heft 4, 2013, S. 493-536.

11. Wolff, H., Bachof, O., Stober, R. Verwaltungsrecht. Band 2. München: Verlag C. H. Beck, 2000.

\section{Normative Acts}

1. Publiskas personas mantas atsavināšanas likums [Law on Alienation of Assets of a Public Entity]. Latvijas Vēstnesis, No. 168(2743), 19.11.2002.

2. Meža likums [Forest Law]. Latvijas Vēstnesis, No. 98/99(2009/2010), 16.03.2000.

3. Publiskas personas finanšu līdzekḷu un mantas izškēerdēšanas novēršanas likums [On Prevention of Squandering of the Financial Resources and Property of a Public Person]. Latvijas Vèstnesis, No. 114(397), 02.08.1995.

4. Likums par ostām [Law On Ports]. Latvijas Vēstnesis, No. 80(211), 12.06.1994.

5. On the National Library of Latvia. Article 3, part 1. Zinnotäjs, No. 1/2, 14.01.1993.

6. Gesetz zur Erhaltung des Waldes und zur Förderung der Forstwirtschaft. Available: https://www. gesetze-im-internet.de/bwaldg/BJNR010370975.html [last viewed 13.06.2019].

\section{Case Law}

1. Decision of the Department of Administrative Cases of the Supreme Court of 16 October 2018 in case No. SKA-1515/2018. Available: https://manas.tiesas.lv/eTiesasMvc/nolemumi/pdf/365429.pdf [last viewed 13.06.2019].

2. Decision of the Department of Administrative Cases of the Supreme Court of 2 October 2018 in case No. 1247/2018. Available: https://manas.tiesas.lv/eTiesasMvc/nolemumi/pdf/364173.pdf [last viewed 13.06.2019]. 
3. Decision of the Department of Administrative Cases of the Supreme Court of 19 April 2018 in case No. 949/2018. Available: https://manas.tiesas.lv/eTiesasMvc/nolemumi/pdf/351712.pdf [last viewed 13.06.2019].

4. Decision of the Department of Administrative Cases of the Supreme Court of 16 January 2018 in case No. SKA-825/2018. Available: http://www.at.gov.lv/downloadlawfile/5420 [last viewed 13.06.2019].

5. Decision of the Department of Administrative Cases of the Supreme Court of 30 January 2018 in case No. 838/2018. Available: https://manas.tiesas.lv/eTiesasMvc/nolemumi/pdf/346942.pdf [last viewed 13.06.2019].

6. Decision of the Department of Administrative Cases of the Supreme Court of 11 January, 2018 in case No. 727/2018. Available: http://at.gov.lv/downloadlawfile/5441 [last viewed 13.06.2019].

7. Decision of the Department of Administrative Cases of the Supreme Court of 25 August 2008 in case No. SKA-574/2008, pp. 11-12. In: Latvijas Republikas Augstākās tiesas Senāta Administratīvo lietu departamenta spriedumi un lēmumi 2008. Rīga: Tiesu namu aǵentūra, 2009, pp. 473-480.

8. Judgment of the Department of Administrative Cases of the Supreme Court of 23 March 2017 in case No. 470/2017. Available: http://at.gov.lv/downloadlawfile/5530 [last viewed 13.06.2019].

9. Judgment of Department of Civil Cases of the Supreme Court of 28 February 2017 in case No. SKC-49/2017. Available: https://manas.tiesas.lv/eTiesasMvc/nolemumi/pdf/301014.pdf [last viewed 13.06.2019].

10. Decision of the Department of Administrative Cases of the Supreme Court of 10 February 2017 in case No. 808/2017. Available: http://at.gov.lv/downloadlawfile/718 [last viewed 13.06.2019].

11. Decision of the Department of Administrative Cases of the Supreme Court of 27 July 2016 in case No. 1190/2016. Available: http://at.gov.lv/downloadlawfile/5148 [last viewed 13.06.2019].

12. Decision of the Department of Administrative Cases of the Supreme Court of 20 November 2015 in case No. 1427/2015. Available: http://at.gov.lv/downloadlawfile/4335 [last viewed 13.06.2019].

13. Decision of the Department of Administrative Cases of the Supreme Court of 11 July 2014 in case No. 874/2014. Available: https://manas.tiesas.lv/eTiesasMvc/nolemumi/pdf/357212.pdf [last viewed 13.06.2019].

14. Decision of the Department of Administrative Cases of the Supreme Court of 3 May 2011 in case No. SKA-482/2011. Available: http://www.at.gov.lv/downloadlawfile/4615 [last viewed 13.06.2019].

15. Decision of the Department of Administrative Cases of the Supreme Court of 22 February 2010 in case No. 101/2010. Available: http://at.gov.lv/downloadlawfile/4747 [last viewed 13.06.2019]. 


\title{
Regimes of Liability for Damages Caused by Abnormally Dangerous Activities
}

\author{
Dr. iur. Lauris Rasnačs \\ Faculty of Law, University of Latvia \\ Lecturer \\ E-mail: lauris.rasnacs@lu.Iv
}

The present paper examines certain aspects of liability for the damages caused by abnormally dangerous activities, mainly viewing them in the context of Latvian law. It addresses the questions which activities (and due to which particularities) shall be treated as abnormally dangerous, what kind of liability models could be applied for the compensation of damages caused by such activities, what is the role of insurance in this respect, to what extent strict liability or stricter forms of liability should be applied, as well as who shall be held liable for these damages.

Keywords: abnormally dangerous activities, strict liability, fault liability, absolute liability, liable person.

\section{Contents}

Introduction . . . . . . . . . . . . . . . . . . . . . . . . . . . . 184

1. Context of Development of Relevant Theories . . . . . . . . . . . . . . . 185

2. Activity or Object................................. . 187

3. Models of Liability . . . . . . . . . . . . . . . . . . . . . . . . . . . . . 192

4. Liable Person .................................... 198

Summary .....................................200

Sources ....................................202

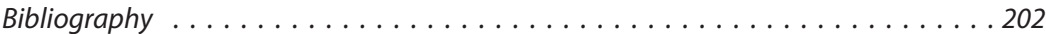

Normative Acts . . . . . . . . . . . . . . . . . . . . . . . . 203

Case Law.....................................203

Other Sources . . . . . . . . . . . . . . . . . . . . . . . . 203

\section{Introduction}

Nearly none of us can imagine our life today without use of things like trains, planes, mechanical motorized vehicles, different chemicals, electricity and products, created in complex and sophisticated processes. All of these make our life more comfortable and our work more effective. However, very few of us remember that at least a part of these things has invoked and some still may invoke processes and situations, causing the risks above the usual everyday level. 
Use of these things and also production thereof in certain situations are called abnormally dangerous activities due to the risks they may cause. Hence, these activities, for instance, the use of nuclear energy for production of electricity, are creating contradictive sentiments. On the one hand, the significant benefits brought by the use of these things and relevant processes to certain individuals, as well as to society in general can hardly be dismissed. Yet, on the other hand, no one should forget, that taking advantage of these things and relevant processes may create highly significant, even 'abnormal' danger, which may cause damages not only to some, but sometimes also to a significant part of society. Therefore, also from legal perspective one of the important questions is how to deal with the situation, when such abnormally dangerous activity has caused damages. What kind of liability model should be applied? How to properly apply insurance in order to obtain damage compensation? Who should perform precautionary measures and who should be held liable for the damages caused? Moreover, what exactly is 'abnormally dangerous activity' and which activities could be treated as abnormally dangerous and which not? These are the questions, which have been discussed between lawyers for quite a while and they will also be analysed in the present paper.

\section{Context of Development of Relevant Theories}

Historical examples, how these things and products entered our lives, may serve as explicit illustrations of relevant risks.

The opening of the Liverpool and Manchester Railway at 1830, although it was a truly remarkable moment in technical achievements of its age, is also known for world's first widely reported railway passenger casualty - the death of British political leader, financier and Member of Parliament William Husskisson. ${ }^{1}$

Several serious dangers are associated with mining processes. For example, on the $22^{\text {nd }}$ of October, 1877 the so-called Blantyre Mining Disaster happened, where, due to ignition of firedamp, over 200 people were killed in coalmines. It is known as the worst-ever Scotland's mining disaster. ${ }^{2}$

The dynamite today is widely used for military, as well as civilian purposes, for example, construction and mining. However, its active substance, nitroglycerin, is extremely explosive both in transportation and use. ${ }^{3}$ Even experiments with nitroglycerin have taken lives of many people, including Emil Oskar Nobel, ${ }^{4}$ the brother of the famous Alfred Nobel, who later invented dynamite as the solution to utilizing the explosive qualities of nitroglycerin in a safer manner. ${ }^{5}$

Finally, yet importantly, nuclear energy, which is highly efficient, yet at the same time involves extremely high risks, which have been expressly manifested

1 Fyfe, P. On the Opening of the Liverpool and Manchester Railway, 1830. BRANCH: Britain, Represantation and Nineteenth - Century History. Ed. D. F. Felluga. Extension of Romanticism and Victorians on the Net. Available: http://www.branchcollective.org/?ps_articles=paul-fyfe-onthe-opening-of-the-liverpool-and-manchester-railway-1830 [last viewed 08.01.2018].

2 Blantyre mining disaster. Available: https://nationalminingmuseum.com/news/blantyre-miningdisaster/ [last viewed 15.01.2018].

3 Nitroglycerine. Available: https://www.britannica.com/science/nitroglycerin [last viewed 15.01.2018].

4 Emil Oskar Nobel. Available: http://enacademic.com/dic.nsf/enwiki/3733568 [last viewed 15.01.2018].

5 Nitroglycerine. Available: https://www.britannica.com/science/nitroglycerin [last viewed 15.01.2018]. 
by some disasters, including infamous Chernobyl. Inter alia, still after more than 30 years, the debates about the real causes of this accident still continue. ${ }^{6}$

It is not surprising that such events do create a debate as to how legal treatment of such situations often associated with so-called abnormally dangerous activities and damages caused thereof. One may say that general rule, requiring fault, as regular condition of liability, ${ }^{7}$ might not be appropriately applied in such cases, because it might be too complicated to examine the existence of misconduct in such cases. Others, even as far back as the nineteenth century, expressed the opinion that if in certain case there is no fault, no liability should be incurred and the loss should be left to lie where it fell. ${ }^{8}$ In the first case, concerns could appear as to whether it is appropriate to distribute civil liability without finding fault. Moreover, even if it might be appropriate in some cases, to what extent the application of such approach should be reasonably limited. In the other case, it could be said, that if the loss should be left to lie, where it fell, then it means that in many cases victims would be left without a chance to have their damages compensated. However, we must keep in mind that tort law is about balancing the freedom of conduct on the one hand, and the protection of rights and interests on the other hand. ${ }^{9}$ Inter alia, it means that, if the provisions of tort law are too strict, despite providing good prospects for the victims to obtain compensation of their damages, these provisions may prevent the use of most innovative technologies and hence, slow down economic progress. Such considerations show that the question of distribution of civil liability in case of damages, caused by the so-called abnormally dangerous activities, have not only legal, but also moralistic, economical and even philosophical aspects. Therefore, establishing the most reasonable solution is not an easy task, which explains, why different countries have applied different solutions, and why the debates for the most appropriate regime continue to this day.

Latvian legal practitioner Mr. Dmitrijs Skačkovs has noted six concepts to be applied or suggested for application in cases, where abnormally dangerous activities have caused damages:

1) The principle that generally civil liability is distributed pursuant to fault, but with exemptions, providing that in some cases liability could be applied without the fault;

2) The concept, which accepts the distribution of civil liability on two separate, equal grounds - as pursuant to the fault as without fault;

3) The concept of 'objective moments', providing that the fault is not a necessary requisite of civil liability, but the lack of fault may only serve as the reason, which may release form liability;

4) The concept of fault, which provides that civil liability could be applied only in case of fault;

6 Emburry-Denis, T. Scientists might be wrong about cause of Chernobyl disaster, new study claims. Available: http://www.independent.co.uk/news/world/europe/chernobyl-disaster-cause-scientistswrong-nuclear-power-plant-accident-ukraine-study-a8067026.html [last viewed 15.01.2018].

7 Bar, C. von. The Common European Law of Torts. Vol. 2. Damage and Damages, Liability for and without Personal Misconduct, Causality and Defences. Oxford: Clarendon Press, 2000, p. 234; Bar, C. von. The Common European Law of Torts. Vol. 1. The Core Areas of Tort Law, its Approximation in Europe, and its Accomodation in the Legal System. Oxford: Clarendon Press, 1998 , p. 23.

8 Markesinis, B. S., Unberath, H. The German Law of Torts. A Comparative Treatise. $4^{\text {th }}$ edition, entirely revised and updated. Oxford, Portland: Hart Publishing, 2002, p. 714.

9 Dam, C. van. European Tort Law. Oxford: Oxford University Press, 2007, p. 181. 
5) The concept applying civil liability only for fault, however, providing that in absence of anyone's fault the loss should be compensated via insurance;

6) The concept of fault, providing that the existence of fault is not necessary for application of civil liability in case of damage caused by abnormally dangerous activity. The mere fact that someone's activity has breached other persons rights and have caused damages, is sufficient in order to apply civil liability. ${ }^{10}$

Most likely this list is far from being exhaustive and the most precise one. However, it gives a good demonstration on variety of theories, which are suggested to be applied if abnormally dangerous activity has caused the damage. These theories, as well as the meaning of abnormally dangerous activities and the search for person, who would be most appropriate to be held liable for the damages, caused by abnormally dangerous activities, will be examined in the following sections of the present paper.

\section{Activity or Object}

The readers of this paper might have a question: why, so far, the author discusses abnormally dangerous activities without explaining the meaning of the term 'abnormally dangerous activity'. The answer lays in the fact that this legal term is among the hard-to-define concepts. As Latvian legal scholar Professor Kalvis Torgāns explains, it is difficult to provide a comprehensive, general definition for abnormally dangerous activity, because usually the objects may impose increased level of danger only in particular circumstances, for instance, in case of certain concentration of active substance. ${ }^{11}$ Legislators of different jurisdictions provide two alternative regimes for regulation of the abnormally dangerous activities and the damages caused by them. One option is to legislate for general provisions that usually are included in civil code of certain country. The examples are Belgium, France, Italy, Luxemburg, the Netherlands, Portugal ${ }^{12}$ and Latvia. Another option is to stipulate special provisions, included in special norms, regulating railway carriage, use of nuclear energy or another particular area, - the solution adopted by Germany and Greece. ${ }^{13}$

A discussion is also present as to whether abnormally dangerous activity should be understood as literally an 'activity' or it can also denote an object, basically, the thing or substance, which might be used in a way causing damage to another person, or the total sum of activities and objects. ${ }^{14}$ The author is of the opinion that abnormally dangerous activity is an activity (interaction of person with a certain object - thing or substance), but not such an object itself. Paragraph 2, article 2347 of the Republic of Latvia Civil Law ${ }^{15}$ regulates the liability for damages caused by abnormally dangerous activity. Unlike most of the provisions of the Republic of

10 Skačkovs, D. Par civiltiesisko atbildību, kad zaudējumus nes paaugstinātas bīstamības avots [On civil liability, when the damages is caused by object of enormous danger]. Jurista Vārds, No. 32(225), 2001. Available: www.juristavards.lv [last viewed 18.01.2018].

11 Torgāns, K. Saistību tiesības [Law of Obligations]. Part II. Rīga: Tiesu namu aǵentūra, 2008, p. 282.

12 Bar, C. von. The Common European Law of Torts. Vol. 2. Damage and Damages, Liability for and without Personal Misconduct, Causality and Defences. Oxford: Clarendon Press, 2000, p. 376.

13 Ibid.

14 Torgāns, K. Saistību tiesības [Law of Obligations]. $2^{\text {nd }}$ extended edition. Rīga: Tiesu namu aǵentūra, 2018, p. 478.

15 Latvijas Republikas Civillikums [Civil Law of the Republic of Latvia]. Zingotājs, No. 1, 1993. 
Latvia Civil Law, it is based on equivalent provisions of article 469 of the Civil Code of the Socialist Soviet Republic of Latvia, instead of Local Civil Laws of the Baltic Provinces of the Russian Empire (Baltijas Vietējo likumu kopojums - in Latvian). Hence, it is reasonable to take into account the also commentaries provided by legal scholars of Soviet era in respect to article 469 of Civil Code of the Socialist Soviet Republic of Latvia. Professor Jānis Vēbers as early as in 1969 has emphasized that abnormally dangerous activity is not the object itself, but the object 'in move' or activity with this object. ${ }^{16}$ Legal scholars from other countries state a similar opinion today. ${ }^{17}$ The wording of paragraph 1, article 5:101 of the Principles of European Tort Law also suggests that 'abnormally dangerous activities' mean 'activities' carried out by a particular person. ${ }^{18}$ At the same time, Professor Kalvis Torgāns does mention the said discussion as to whether the abnormally dangerous activity could be an 'activity' or 'object' or the total sum of activities and objects. He expresses an opinion, suggesting that all three options are possible. ${ }^{19}$ However, the author of present paper does not agree with such opinion. As already mentioned above, he adheres to the opinion that the activity, not the object or its sum with an activity, is the abnormally dangerous activity. The arguments below substantiate this position.

First of all, it should be kept in mind, which qualities might make something 'abnormally dangerous'. Paragraph 2, article 5:101 of Principles of European Tort Law gives probably the most precise description of the qualities. This provision suggests that

\section{an activity is abnormally dangerous if: \\ a) It creates a foreseeable and highly significant risk of damage even when all due care is exercised in its management, and \\ b) It is not a matter of common usage.}

In other words, an abnormally dangerous activity is an activity associated with significant risks, which still exist even if due precautions are exercised and the activity is of the kind that may be exercised by particular persons, not by everyone. Other sources also mention these qualities, especially emphasizing the impossibility to reduce all risks, even exercising due care. ${ }^{20}$ Usually it falls within the scope of court's duties to examine, whether the activity under question in particular case is abnormally dangerous. Such examination quite often requires a deep analysis. For instance, in one case court examined the storage of fuel and other oil products in underground tanks in circumstances, when leakage occurred from these tanks and caused damage to other persons. The court emphasized that a possible abnormal danger should be examined not from perspective that certain damage has been done (i.e. from negative consequences), but from the perspective, whether the storage of the said products involves risks, which cannot be removed even by exercising due care. As in that particular case the court found that fuel and oil products could be

16 Vēbers, J. Saistības no kaitējuma nodarīšanas [Obligations from Causing the Damage]. Rìga, 1969, pp. 39-40.

17 Boston, G. W. Strict Liability for Abnormally Dangerous Activity: The Negligence Barrier. San Diego Law Review, No. 597, 1999, p. 650.

18 European Group on Tort Law. Principles of European Tort Law. Available: http://civil.udg.edu/ php/biblioteca/items/283/PETL.pdf [last viewed 12.02.2018].

19 Torgāns, K. Saistību tiesības [Law of Obligations]. Part II. Rỉga: Tiesu namu ag̉entūra, 2008, p. 281.

20 Boston, G. W. Strict Liability for Abnormally Dangerous Activity: The Negligence Barrier. San Diego Law Review, No. 597, 1999, pp. 650-652. 
stored and also transfused and transported without the risk of damage, if due care is exercised, no abnormally dangerous activity could be found in that particular case. ${ }^{21}$ In another case, the court examined demolition of buildings, using explosives. In order to explore the matter properly, the court summoned a team of experts to provide their opinion. It is worth to mention that even the experts arrived at different opinions. However, the majority of experts came to the conclusion that significant risks of causing damage to other persons and their property could not be removed even if due care is exercised during the demolition works. Therefore, the court in that particular case ruled that performance of particular demolition works should be regarded as abnormally dangerous activity. ${ }^{22}$

Latvian legal scholar and practitioner Dr. Jānis Kubilis has suggested that in every case, when the damage is caused by abnormally dangerous activity, certain activity or inactivity of some person could be found, at least indirectly. ${ }^{23}$ Although a certain result, for instance, leakage of chemicals or explosion of some substance and the damages caused thereof may not be intended by that particular person, the result would not have come about, if this person in some manner did not interact (i.e. was not subject to some activity) with the particular substance, at the very least, storing this substance. Uranium (U) is a substance of such nature. This substance, namely, metal, could be found naturally as an oxide, which historically was used for colouring purposes. ${ }^{24}$ If its concentration does not exceed natural level, it bears no particularities or risks associated with nuclear energy. ${ }^{25}$ Such risks and properties uranium adopts only after performance of certain chemical procedures. ${ }^{26}$ Therefore, the opinion that activity is what could be abnormally dangerous in certain circumstances, is rather correct.

A certain misunderstanding may be caused by the fact that some jurisdictions provide stricter and sometimes even a strict liability for damage, the cause of which is related to some object, usually movable or immovable thing. For example, article 1386 of the French Civil Code provides strict liability for the damage caused by collapse of buildings, if this is the consequence of inadequate maintenance or a defect in construction. ${ }^{27}$ At the first glance, it might appear a proof that also the objects might be abnormally dangerous themselves. However, such impression cannot be supported. The devil hides in details and no less so, if the matter relates to the law. Initially, in such a case not only the object, but also some activity or inactivity could be attributed to the cause of damage, for instance, inadequate maintenance or an error, which has led to the defect in construction. For instance, German legal scholar Christian von Bar speaks about liability on the basis of article 1386 of the French Civil Code as about the liability for dangerous status

21 Boston, G. W. Strict Liability for Abnormally Dangerous Activity: The Negligence Barrier. San Diego Law Review, No. 597, 1999, p. 650.

22 Cobb, M. “The Wrong Approach at the Wrong Time?": Maine Adopts Strict Liability for Abnormally Dangerous Activities in Dyer v. Maine Drilling and Blasting, Inc. 63 Maine Law Review, No. 331, 2010, p. 346.

23 Kubilis, J. Latvijas deliktu tiesību modernizācijas galvenie virzieni. Promocijas darbs [Main Issues Regarding Modernisation of Tort law in Latvia. Doctoral thesis]. Rìga: University of Latvia, 2016, p. 225.

24 Uranium. Available: http://www.chemistryexplained.com/elements/T-Z/Uranium.html [last viewed 18.01.2018].

25 Uranium - U. Available: https://www.lenntech.com/periodic/elements/u.htm [last viewed 18.01.2018].

26 Ibid.

27 Dam, C. van. European Tort Law. $2^{\text {nd }}$ edition. Oxford: Oxford University Press, 2013, pp. 462-463. 
of immovable property (Haftung für den gefährlichen Zustand von Immobilien in German), ${ }^{28}$ which thereby leads to the thoughts that behind every dangerous status of movable or immovable thing lays a certain activity (or inactivity), which has made the object dangerous and therefore this activity, and not the object, is the decisive factor of the danger. Then, taking into account such activity or inactivity, there is no reason to conclude that the said object comprises particularities of abnormally dangerous activity. Secondly, it should be emphasized that, since certain activity or inactivity, inadequate maintenance or an error has been in place, which has led to the defect in construction, there is no reason to conclude that the object under question contains risks, which cannot be eliminated even with exercising due care. Thirdly, as a certain activity or inactivity, which has caused damage, could be established, there may be a reason to conclude that liability for the caused damages is not a strict liability, but instead a fault liability, just possibly with some modifications, which in some sense make it stricter. Consequently, it may be concluded that the legislator of certain jurisdiction may provide a stricter or strict liability also for the damages, which are related to some particular objects, not only to the activities, however, it does not give the reason to conclude that these objects could be treated as 'abnormally dangerous objects'.

Unlike the jurisdictions with general provisions, applicable to all kinds of potential abnormally dangerous activities, several other jurisdictions, for instance, Germany and the United Kingdom, have chosen to regulate each type of activity by special provisions. ${ }^{29}$ Also historically, the first attempt to regulate the liability for damage caused by abnormally dangerous activity was made by special provisions - Prussian Railway Act of 1838 or, to be more precise, "The Law on Railway Undertakings" (Gesetz über die Eisenbahn-Unternehmungen in German). ${ }^{30}$ One may say that certain activities, regulated by such particular provisions, may not always be abnormally dangerous in the sense of lack of reasonable possibility by eliminating all the potential risks via exercising due care. Such statement might be correct. However, the benefit of such special provisions is a greater extent of certainty about the particular activity, which is the subject of these special provisions, and also a greater extent of certainty about particular model of liability and the potentially liable person. As appositely noted in Latin proverb, too general provisions in law are hazardous - omnis definitio in lege periculosa est. Hence, general provisions regarding liability for abnormally dangerous activity contain greater risks of incorrect interpretation and/or application. On the other hand, general provisions are better suited for application in the situation when the understanding of some activity as abnormally dangerous is outdated, or there is some new activity, which is not particularly regulated yet, but which, in fact, may appear to be abnormally dangerous. Dr. Jānis Kubilis also has provided similar considerations, stating that the provisions of law should be dynamic and interpreted not only according to the factual circumstances of certain case, but also according

28 Bar, C. von. Gemeineuropäisches Deliktsrecht. Erster Band. Die Kernbereiche des Deliktsrechts, seine Angleichung in Europa und seine Einbettung in die Gesamtrechtsordnungen. München: C. H. Beck'sche Verlagsbuchhandlung, 1996, S. 235.

29 Dam, C. van. European Tort Law. $2^{\text {nd }}$ edition. Oxford: Oxford University Press, 2013, p. 440.

30 Gesetz über die Eisenbahn-Unternehmugen vom 3 November 1838. Available: https:// www.lwl.org/westfaelische-geschichte/que/normal/que1030.pdf [last viewed 01.04.2019]. 
to the progress of science and technology, as well as according to the other factors. ${ }^{31}$ In the light of such considerations, the author of present paper arrives at the conclusion that possibly the best option for regulating the liability for damages caused by abnormally dangerous activity, is to include in the law general provisions, as well as particular provisions applicable to each specific activity. However, these general provisions should be treated as lex generalis and applied only to the extent, where the matter is not covered by particular provisions.

In context of models to regulate the liability for damages caused by abnormally dangerous activity, a few words should be said about the provisions of Latvian Civil Law. Paragraph 2 article 2347 of the Latvian Civil Law could be treated as general provision, imposing an increased liability on persons, whose activity is associated with an increased risk to other, surrounding persons. However, by amendments to the Latvian Civil Law, adopted on 29 November, 2012, some examples for the said activities, such as transport (transportation), enterprise, construction and dangerous substances were added to the wording of the said provision of Latvian Civil Law. ${ }^{32}$ Although such amendments were guided by the noble intention to make that provision, in fact, it yielded the exactly opposite result. As Dr. Jānis Kubilis has validly indicated, the consideration that each transport during its use or each construction process create increased risk, could not be supported. The answer to the question, whether an activity should be treated as particularly dangerous, could be obtained only in the light of particular circumstances. ${ }^{33}$ The author of the present paper completely supports such opinion and would like to emphasize that the same type of activity in certain circumstances may impose increased danger, while in others - not. However, the said amendments to the law may create a misleading impression, that listed activities could be treated as dangerous without analysis of particular circumstances. Hence, the author of the current paper also agrees with other critical remarks, expressed by Dr. Jānis Kubilis and stating that it is not advisable for the legislator to emphasize some potential abnormally dangerous activities. ${ }^{34}$ If the legislator desires to apply an increased liability to all activities of a

31 Kubilis, J. Atbildības par paaugstinātas bīstamības avota radītu kaitējumu problemātika un modernizācija [The Current Issues and Modernisation of Liability for Damage Caused by Abnormally Dangerous Activity]. In: Tiesību efektīvas piemērošanas problemātika. Latvijas Universitātes 72. zinātniskās konferences rakstu krājums. Rīga: University of Latvia Press, 2014, p. 203.

32 After the amendments from 29 November, 2012 the second paragraph of article 2347 Civil Law of the Republic of Latvia provides: "A person whose activity is associated with increased risk for other persons (transport, undertakings, construction, dangerous substances, etc.) shall compensate for losses caused by the source of increased risk, unless he or she proves that the damages have occurred due to force majeure, or through the victim's own intentional act or gross negligence. If a source of increased risk has gone out of the possession of an owner, holder or user, through no fault of theirs, but as a result of unlawful actions of another person, such other person shall be liable for the losses caused. If the possessor (owner, bailee, user) has also acted without justification, both the person who used the source of increased risk and its possessor may be held liable for the losses caused, having regard to what extent each person is at fault."

33 Kubilis, J. Atbildības par paaugstinātas bīstamības avota radītu kaitējumu problemātika un modernizācija [The Current Issues and Modernisation of Liability for Damage Caused by Abnormally Dangerous Activity]. In: Tiesību efektīvas piemērošanas problemātika. Latvijas Universitātes 72. zinātniskās konferences rakstu krājums. Rīga: University of Latvia Press, 2014, p. 203.

34 Kubilis, J. Latvijas deliktu tiesību modernizācijas galvenie virzieni. Promocijas darbs [Main issues regarding modernisation of tort law in Latvia. Doctoral thesis]. Riga: University of Latvia, 2016, p. 226. 
certain type, it is advised to include the relevant provisions in the specific provision of law, regulating certain type of activities, like certain means of transportation, use of certain type of energy or other.

The author of the present paper found particularly interesting the provisions, implemented by the Estonian legislator. The provisions, set down in the articles 1056-1060 of the Estonian Law of Obligations Act could be treated as a quite successful attempt to merge all the above-mentioned theoretical approaches in order to provide legal environment, which would be at least for the major part clear and avoiding the said theoretical discussions. Thus, article 1056 of the said act avoids the discussion about a 'thing' or 'activity' by referring to the 'major source of danger', which, pursuant to the first paragraph of the said article may be a thing as well as an activity. The said act does not refer to the exhaustive list of 'major sources of danger', but rather provides a description of particularities, which the certain thing or activity should have in order to be found as the major source of danger. At the same time, the said act also explicitly mentions certain objects, which involve stricter or strict liability - use of motor vehicle, dangerous structure or thing, or other structure or animals. However, unlike the Latvian law, the Estonian act does not merely mention these objects, but also provides separate preconditions for application of liability, if the damage has been caused by one of these objects. ${ }^{35}$

\section{Models of Liability}

As it was mentioned earlier in this paper, Mr. Dmitrijs Skačkovs listed six different models of liability, which can possibly be applied in cases when the damages are caused by abnormally dangerous activity. However, such a detailed list probably is overly sophisticated. Instead, the major debate exists between two major models of liability - strict liability and liability for fault, probably with some modifications. The present paper also will adhere to these two models and analyse them. The modifications of liability for fault usually may exist as raising of the standard of care or shifting the burden of proof. ${ }^{36}$

A certain model of liability shall be chosen by the legislator of particular country. In this respect, the German Supreme Court Bundesgerichtshof has validly emphasized that 'it was not at liberty to pre-empt the legislature and to undertake an extension of the liability criteria structures without a specific statutory basis'. ${ }^{37}$ Even in the United Kingdom the House of Lords has given a similar statement: 'as general rule it is more appropriate for strict liability in respect of operations of high risk to be imposed by Parliament than by the courts' ${ }^{38}$

However, the Dutch legal scholar Cees van Dam has voiced the opinion that there is no exact borderline between liability for fault and strict liability. Elements of stricter liability can be found inside the framework of fault liability and elements of fault can be found within the framework of strict liability. ${ }^{39}$ Moreover, strict liability as a concept is far from clear, - the phantom of fault still hides in the shadows of

35 Estonian Law of Obligations Act. Available: https://www.riigiteataja.ee/en/eli/506112013011/ consolide [last viewed 07.04.2019].

36 Dam, C. van. European Tort Law. $2^{\text {nd }}$ edition. Oxford: Oxford University Press, 2013, pp. 302-306.

37 Bar, C. von. The Common European Law of Torts. Vol. 2. Damage and Damages, Liability for and without Personal Misconduct, Causality and Defences. Oxford: Clarendon Press, 2000, p. 382.

38 Ibid., p. 390.

39 Dam, C. van. European Tort Law. $2^{\text {nd }}$ edition. Oxford: Oxford University Press, 2013, p. 297. 
fault liability or, to coach it in more legal terms, the elements of negligence still play a role in rules of strict liability. ${ }^{40}$

The origins of strict liability, also called risk liability, objective liability or indirect liability, ${ }^{41}$ are a bit controversial. Some legal scholars have given an opinion that the origins of strict liability may be traced back even to Roman Law, where lex Aquilia may be treated as the first example of strict liability. ${ }^{42}$ However, other legal scholars as from the common law countries, ${ }^{43}$ as well as the Continental Europe legal system, ${ }^{44}$ have criticized such opinion. Other authors provide opinion that lex Aquilia is actually the first known historical example of fault liability. ${ }^{45}$ However, such opinion is difficult to support. Roman lawyers have provided comments regarding lex Aquilia, suggesting a rather careful examination of the fault of every person and the respective causality. For instance, Roman lawyer Celsus wrote that, if the slave was attacked by two persons and died as a result, then the attacker, who inflicted a mortal wound upon the slave, would be liable only for wounding, not killing of the slave. The second person will be liable for killing of the slave, as the slave actually perished as a result of another wound. It seems thus to Marcellus, and it is the more likely option. ${ }^{46}$ Such opinion is also similar to the subsequent causa superveniens theory. ${ }^{47}$

A greater substantiation seems to support the opinion that strict liability was actually invented by the said Prussian Railway Act of 1838. Contrary to the French Civil Code (and later German Civil Code Bürgerliches Gesetzbuch), famous for all-embracing, general provisions of law, the Prussian Railway Act stipulated specific provisions of liability to be applied in the very specific area railway transportation. ${ }^{48}$ Regarding the origins of strict liability, German legal scholar Dr. Christian von Bar emphasized that invention of strict liability was related to the new objects, use or other actions with whom were related at the time uncontrollable risks. ${ }^{49}$ It is an important aspect to be taken into account the existence of uncontrollable risks as a necessary precondition of strict liability. It shall be kept in mind during examination, whether particular activity should be treated as abnormally dangerous and hence, whether the rules of strict liability

${ }_{40}$ Dam, C. van. European Tort Law. $2^{\text {nd }}$ edition. Oxford: Oxford University Press, 2013, p. 297.

41 Bar, C. von. The Common European Law of Torts. Vol. 2. Damage and Damages, Liability for and without Personal Misconduct, Causality and Defences. Oxford: Clarendon Press, 2000, p. 338.

42 Richard, A., Epstein, A. A Common Lawyer Looks at Constitutional Interpretation. 72 U.L.REV., 699, 704, 1992. Quoted from: Getzler, J. Richard Epstein, Strict Liability, and the History of Torts. Journal of Tort Law, Vol. 3, Issue 1, 2010, art. 3. Oxford: University of Oxford, 2010, p. 1.

43 Getzler, J. Richard Epstein, Strict Liability, and the History of Torts. Journal of Tort Law, Vol. 3, Issue 1, 2010, art. 3. Oxford: University of Oxford, 2010, p. 1.

44 Bar, C. von. The Common European Law of Torts. Vol. 2. Damage and Damages, Liability for and without Personal Misconduct, Causality and Defences. Oxford: Clarendon Press, 2000, p. 367.

45 Markesinis, B. S., Unberath, $H$. The German Law of Torts. A Comparative Treatise. $4^{\text {th }}$ edition, Entirely Reversed and Updated. Oxford, Portland: Hart Publishing, 2002, p. 714.

46 D. 9,2,11,3 (Ulp. 18 ad ed.). Quoted from: Sirks, A. J. B. The slave who was slain twice: causality and the lex Aquilia (Iulian. 86 dig. D. 9,2,51). The Legal History Review, 79, 2011. Brill Academic Publishers, p. 315.

47 Sirks, A. J. B. The slave who was slain twice: causality and the lex Aquilia (Iulian. 86 dig. D. 9,2,51). The Legal History Review, 79(2011). Brill Academic Publishers, p. 313.

48 Markesinis, B. S., Unberath, $H$. The German Law of Torts. A Comparative Treatise. $4^{\text {th }}$ edition, entirely revised and updated. Oxford, Portland: Hart Publishing, 2002, p. 715.

49 Bar, C. von. The Common European Law of Torts. Vol. 2. Damage and Damages, Liability for and without Personal Misconduct, Causality and Defences. Oxford: Clarendon Press, 2000, pp. 344-345. 
should be applied (and, if so, is it prescribed by applicable law). Such uncontrollable risks are more inherent to activities with objects, which at actual time are new for the mankind, as with time flow humans learns how to control these risks. Therefore, it also should be kept in mind that activities, which were found to be objects of enormous danger some time ago, should not necessarily be found as such in the present time. For instance, at present time, new risks and, consequently, the substantial alterations of liability rules are considered in respect to the various types of artificial intelligence ${ }^{50}$ and robotics, ${ }^{51}$ especially regarding the use of autonomous vehicles $^{52}$ as a form of robot that is capable of, through the use of a computer, making decisions about some or all of the vehicle's movements with little to no human intervention. ${ }^{53}$ Although the author does not want to expand this topic, as it deserves its own, separate discussion, it is worth to mention that probably after some time humankind will learn how to eliminate the risks associated with the use of artificial intelligence, robotics and autonomous vehicles, and the necessity for strict or stricter liability in this respect will cease to exist. Moreover, the difficulties, which are of legal importance, sometimes might be solved more suitably with technical, not legal remedies. For instance, it is suggested that to solve the difficulties related to gathering evidence that the damage has been caused with the defect of autonomous vehicle, a particular tracing system should be implemented. ${ }^{54}$

Paragraph 1, article 7:102 of the Principles of European Tort Law characterizes strict liability with two features: (1) examination of respondent's fault has no importance in this model of liability and (2) respondent can use for his defence only certain circumstances, if such are in place, for instance, force majeure. Latvian legal scholar and practitioner, Associated Professor Dr. Jānis Kārkliņš mentions the list of catalogues of excuses provided by law, that might be different in each particular area. The excuses in cases when the damage is caused by abnormally dangerous activity generally include force majeure, gross negligence or intent of injured person, loss of possession over the respective object as the result of unlawful activity of the third party. ${ }^{55}$

Strict liability could be divided into three types. Liability with an extra debtor provides that someone is jointly liable with the person, who actually caused the damage by this negligent conduct. Liability for a defective object may be applied

50 Communication from the European Commission to the European Parliament, the European Council, the Council, the European Economic and Social Committee and the Committee of the Regions. Artificial Intelligence for Europe, p. 17. Available: https://ec.europa.eu/digital-singlemarket/en/news/communication-artificial-intelligence-europe [last viewed 07.04.2019].

51 European Parliament resolution with recommendations to the Commission on Civil Law Rules on Robotics (2015/2103(INL)); European Economic and Social Committee opinion on AI (INT/806EESC-2016-05369-00- 00-AC-TRA). Available: http://www.europarl.europa.eu/sides/getDoc. do? pubRef=-//EP//TEXT+TA+P8-TA-2017-0051+0+DOC+XML+V0//EN [last viewed 07.04.2019].

52 Rosenberg, A. Strict Liability Imagining a Legal Framework for Autonomous Vehicles. Tulane Journal of Technology and Intellectual Property, Vol. 20, Fall 2017. Tulane University School of Law, p. 224.

53 Ibid., p. 207.

54 A Common EU Approach to Liability Rules and Insurance for Connected and Autonomous Vehicles. European Added Value Assessment. Accompanying the European Parliament's Legislative Own-Initiative Report. (Rapporteur: Mady Delvaux). Study. EPRS/European Parliamentary Research Service. February 2018, p. 27. Available: http://www.europarl.europa.eu/RegData/etudes/ STUD/2018/615635/EPRS_STU(2018)615635_EN.pdf [last viewed 07.04.2019].

55 Kārklinšs, J. Stingrās atbildības izslēdzošie apstākḷi [Exceptions of Strict Liability]. In: Ārvalsts investīcijas: kad tiesības mijiedarbojas. Latvijas Universitātes 74. zinātniskās konferences rakstu krājums. Rìga: University of Latvia Press, 2016, p. 123. 
to someone in case when a product (goods or service) produced, distributed or provided by this person turns out to be defective and causes damage to other persons. ${ }^{56}$ It is also called a 'product liability' and may be traced back to several court cases of common law countries, for instance, the famous Donoghue $v$. Stevenson case, where the claimant discovered a snail in the bottle of drink, which later defined by the court as a defective product. Interestingly, the commentators from the common law countries refer to this case as an example of liability for negligence, not strict liability. ${ }^{57}$ Liability with a limited defence is mentioned as "perhaps the most classical and genuine form of strict liability". This liability is independent of the defendant's conduct and independent of the considerations whether the defendant has acted as the reasonable person and has performed sufficient precautionary measures. As already mentioned, only certain excuses, exhaustively prescribed by law, for instance, negligence or intent of injured person, may serve as defence in this form of liability. ${ }^{58}$

Legal scholars have mentioned several objectives of strict liability. One of the opinions is that the purpose of strict liability is to provide balance between the interests of involved persons. On the one hand, these are the interests to operate in and to obtain benefit from the situation of increased risk. On the other hand, there is an impossibility to exercise complete control over relevant risks. In such circumstances, compensation of the damages has a priority. ${ }^{59}$ However, this balance is not the only objective of strict liability. Other objectives include (a) imposing liability on person, who, due to his or her knowledge and life experience is better equipped to foresee risks, associated with the use of particular object, and (b) increasing the level of public safety. These objectives may be illustrated with an example, when parents can be held liable for the damage caused by use motor vehicle (for instance, moped), belonging to a minor under the age of sixteen. ${ }^{60}$ Parents are better equipped to foresee the risks, associated with the use of this vehicle, and imposing stricter liability upon them may increase the level of public safety.

Since strict liability, especially the strict liability with limited defence imposes liability without examining whether the defendant has acted reasonably, the application of this form of liability should be narrow. First of all, its application should be limited by certain provisions of law determining in which cases and to which persons this form of liability should be distributed. This objective could be better achieved, if the liability for damages, caused by abnormally dangerous activity and application of strict liability are provided is enshrined in special provisions of law, instead of stipulated by general rules. Secondly, for instance, in Germany, the application of strict liability is limited also with a certain monetary amount. The injured person or the person who has suffered damages may claim compensation according to the rules of strict liability within the given limitation. If this person would like to receive the compensation above the given limitation, he

56 Dam, C. van. European Tort Law. $2^{\text {nd }}$ edition. Oxford: Oxford University Press, 2013, pp. 300-302.

57 Giliker, P., Beckwith, S. Tort. $4^{\text {th }}$ edition. London: Thomson Reuters, Sweet \& Maxwell, 2011, p. 261.

58 Dam, C. van. European Tort Law. Oxford: Oxford University Press, 2007, pp. 258-259.

59 Kārkliņš, J. Conditions for Tort Liability. In: Torgāns, K., Kārkliņš, J., Bitāns, A. Līgumu un deliktu problēmas Eiropas Savienībā un Latvijā [Issues of Torts and Contracts in EU and Latvia]. Rìga: Tiesu namu aǵentūra, 2017, p. 299.

60 Bar, C. von. The Common European Law of Torts. Vol. 2. Damage and Damages, Liability for and without Personal Misconduct, Causality and Defences. Oxford: Clarendon Press, 2000, p. 328. 
or she may claim it on the basis of fault liability. ${ }^{61}$ Such limitation is reasonable, because in the areas subject to provisions of strict liability insurance is expected to be obtained ${ }^{62}$ and such limitation provides more appropriate possibility for liability insurance. German legal scholar Christian von Bar has also provided opinion that paragraph 1, article 29bis of the Belgian law on obligatory liability insurance for motor vehicles, provides liability of insurer, who has insured the liability of the owner of keeper of the vehicle. ${ }^{63}$ In general, such opinion could not be supported, particularly with the reservation about Belgian law, and the author of the present paper does not regard himself as fully competent to participate in discussion. Although insurance undoubtedly plays an import role in tort law, ${ }^{64}$ it has a rather complementary purpose, as the obligation of the liability insurer to pay the insurance indemnity generally depends at least on two additional aspects: (a) whether the insured person is held liable for particular damage and (b) whether the particular damage falls within the scope of insured risks.

There is one more legal term - 'absolute liability', which should be discussed in the context of strict liability. According to Dr. Jānis Kārklinšs, absolute liability is present in case when even the force majeure event cannot serve as the excuse from liability. However, it is not a separate liability model in any of the legal systems. The closest to this is the model of liability set down in Vienna convention on civil liability for nuclear damage. ${ }^{65}$ The first paragraph of article IV of this convention provides that liability of the operator for nuclear damages are absolute, and force majeure cannot be an excuse exempting operator from liability. However, further paragraphs of the same article provide several exemptions releasing the operator from liability. To a certain extent, similar provisions, according to Dr. Jānis Kārkliņš, could be found in article 7:102 of the European Principles of Tort Law. Therefore, Jānis Kārklinšs suggests that this model could be named 'quasi-absolute liability'. ${ }^{6}$ The author of present paper does not agree that this 'quasi-absolute liability' is something different from strict liability. In fact, the 'quasiabsolute liability' in this sense is the same strict liability with a limited defence as defined by Cees van Dam and noted above. Although force majeure is not always the valid excuse under the said Vienna convention, the paragraphs 2, 3 and 5 of the article IV of the said convention provide its own catalogue of excuses for liability of the operator of the nuclear installation. Finally, yet importantly, it shall be kept in mind that article 7:102 of the European Principles of Tort Law, mentioned by Jānis Kārkliņš, also are addressing strict liability, not any other separate form of liability.

As regards fault liability for abnormally dangerous activities, interesting provisions could be found in Spanish law. Spanish Civil Code does not provide general regulations for liability for abnormally dangerous activities. It provides instead narrowly defined list of such activities, where the liability for risk or 'use

${ }^{61}$ Dam, C. van. European Tort Law. Oxford: Oxford University Press, 2007, p. 257; Markesinis, B. S., Unberath, $H$. The German Law of Torts. A Comparative Treatise. $4^{\text {th }}$ edition, entirely revised and updated. Oxford, Portland: Hart Publishing, 2002, p. 717.

62 Bar, C. von. The Common European Law of Torts. Vol. 2. Damage and Damages, Liability for and without Personal Misconduct, Causality and Defences. Oxford: Clarendon Press, 2000, p. 324.

63 Ibid., p. 403.

64 Dam, C. van. European Tort Law. $2^{\text {nd }}$ edition. Oxford: Oxford University Press, 2013, p. 221.

65 Vienna convention on civil liability for nuclear damage. Available: https:/www.iaea.org/sites/ default/files/infcirc500.pdf [last viewed 29.01.2018].

66 Kārkliņš, J. Conditions for Tort Liability. In: Torgāns, K., Kārkliņš, J., Bitāns, A. Līgumu un deliktu problēmas Eiropas Savienībā un Latvijā [Issues of Torts and Contracts in EU and Latvia]. Rīga: Tiesu namu aǵentūra, 2017, pp. 299, 301. 
of things' is applicable. Among others this list includes regulation of liability for use of motorized vehicles. However, this liability for risk is not the strict liability. In Spanish it is called culpa quasi objectiva, literally - 'quasi strict liability', which, in fact, is the same as fault liability with shifted burden of proof. ${ }^{67}$ It provides that within the limits exists the presumption of the fault of the person, who operated with increased level of risk or performed some abnormally dangerous activity. In addition, there is also a presumption of causality, i.e. that the presumed fault of particular person has caused certain damage. Therefore, this model of liability provides a twofold presumption. It is illustrated with the following example from the case law. The cyclist was killed during a road traffic accident in unexplained circumstances. Spanish Supreme court ruled that, at first, it is presumable that motorist has infringed road traffic rules, secondly - that it is presumable that the cyclist has been killed by such infringement of motorist. ${ }^{68}$ In other words, the presumption refers to the fault of respondent, as well as to the causality between fault and the actual damage. However, the respondent may escape the liability by rebutting either both presumptions, or at least the presumption of causality, proving that the damage was caused by other circumstance and/or by another person. On this ground, 'quasi-objective liability' should be distinguished from strict liability. Although in quasi-objective liability the examination of respondent's fault in fact plays just a secondary role, the respondent may defend himself not only with an exclusive list of defences, such as a force majeure circumstances, but with any facts, which may help him to rebut the said presumptions. However, here comes also at least one of the uncertainties in distinction between strict liability and fault liability mentioned by Cees van Dam. ${ }^{69}$ Rebutting of causality usually will lead to conclusion that fault or at least activity of someone else's rather than respondent's has caused the damage. Hence, such defence will be based on arguments about the third party's conduct, which, pursuant to point 2, paragraph 1, article 7:102 of the Principles of European Tort Law is one of defences in case of strict liability.

Also, one can ask whether this quasi-objective liability, which is based on rebutting of the said presumptions, should not be distinguished from fault liability with shifted the burden of proof. The author of the present paper is of the opinion that both these sub-models of fault liability are actually the same as rebutting of the aforementioned presumptions, inter alia, presumption of fault, in fact, includes the shifted burden of proof. Dutch legal scholar Cees van Dam explains that shifted burden of proof is often applied in cases, where the defendant possesses more information about the cause of the damage than the claimant. ${ }^{70}$ The author of the present paper adheres to the opinion that it may be so in some cases, while in other cases such considerations would not hold true. For instance, if the damage is caused by the use of motorized vehicle, the defendant will not always be better informed about the cause of damage than the claimant.

Another form of stricter fault liability is the liability with raised standard of care. Usually it refers to the duty of defendant to prove that he has taken sufficient precautionary measures as some kind of objective standard for defendant's

${ }^{67}$ Dam, C. van. European Tort Law. $2^{\text {nd }}$ edition. Oxford: Oxford University Press, 2013, p. 304.

68 Bar, C. von. The Common European Law of Torts. Vol. 2. Damage and Damages, Liability for and without Personal Misconduct, Causality and Defences. Oxford: Clarendon Press, 2000, pp. 362-363.

69 Dam, C. van. European Tort Law. $2^{\text {nd }}$ edition. Oxford: Oxford University Press, 2013, p. 297.

70 Ibid., p. 305. 
particular activity. ${ }^{71}$ Therefore, it includes some elements from shifted burden of proof.

Different models of liability also may be applied regarding different types of damages. Latvian legal doctrine provides that in case when the damage is caused by abnormally dangerous activity, it is a strict liability case. ${ }^{72}$

However, one more important distinction is provided by Latvian Supreme Court in judgment from 5 March 2015 in case No. SKC-250/2015 C04327108. ${ }^{73}$ The claimant was a public transport passenger, injured during traffic accident while she was riding in public transport. As a result of collision, she experienced pain and suffered several bodily injuries. The respondent was the public transport operator. Traffic accident was caused by another person, not by the driver of the particular public transport vehicle (bus). In paragraph 15 of the said judgment, Latvian Supreme Court stressed that wording of paragraph 2, article 2347 of the Civil Law of Republic of Latvia regulating liability for damages caused by abnormally dangerous activity, provides a regulation regarding pecuniary damages (zaudējumi - in Latvian) only, as the wording of this provision suggests, whereas paragraph 1 , article 2347 of the Civil Law of the Republic of Latvia, after amendment on 29 November 2012, explicitly regulates the liability for pecuniary, as well as non-pecuniary damage. However, this paragraph 1 does not provide for a strict liability for these damages. In such circumstances, Latvian Supreme Court concluded that the will of the legislator was that only pecuniary damages caused by abnormally dangerous activities, should be compensated on strict liability basis. If the abnormally dangerous activity has caused non-pecuniary damages, they should be awarded on the basis of the fault liability. Taking into account that the choice of applicable liability model falls within the exclusive competence of legislator, the author of the present paper is of the opinion that the Latvian Supreme Court's findings are correct. Latvian Supreme Court re-confirmed similar findings in judgment from 3 June, 2016, case No. SKC-143/2016 C28244808. ${ }^{74}$

\section{Liable Person}

A further question of significance concerns the person who should be held liable for the damages caused by the abnormally dangerous activity, if the strict liability model is applicable in such case.

Generally, tort law adheres to the opinion that everyone shall be held liable for his/her actions, that have harmed other persons. ${ }^{75}$ The general rule regarding liability for abnormally dangerous activities provides a similar view. The liable person should be the keeper of the object, who has performed a certain abnormally dangerous activity with this object, in other words, 'keeper of substance' or

1 Dam, C. van. European Tort Law. $2^{\text {nd }}$ edition. Oxford: Oxford University Press, 2013, p. 302.

72 Torgāns, K. Conditions for Tort Liability. In: Torgāns, K., Kārkliņšs, J., Bitāns, A. Līgumu un deliktu problēmas Eiropas Savienībā un Latvijā [Issues of Torts and Contracts in EU and Latvia]. Rìga: Tiesu namu aǵentūra, 2017, p. 131.

73 Latvijas Republikas Augstākās tiesas Civillietu departamenta 2015. gada 5. marta spriedums lietā Nr. SKC-250/2015 C04327108 [Judgment of the Civil Department of the Supreme Court of the Republic of Latvia in case No. SKC-250/2015 C04327108 from 5 March, 2015]. Not published.

74 Latvijas Republikas Augstākās tiesas Civillietu departamenta 2016. gada 3. jūnija spriedums lietā Nr. SKC-143/2016 C28244808 [Judgment of the Civil Department of the Supreme Court of the Republic of Latvia in case No. SKC-143/2016 C28244808 from 3 June, 2016]. Not published.

$75 \mathrm{Raz}$, J. Responsibility and the Negligence standard. Oxford Journal of Legal Studies, Vol. 30, Issue 1, 2010, p. 11. 
'operator of the installation'. ${ }^{76}$ The legal doctrine provides that the ownership of the thing is naturally a significant indicator of the status of keeper, but it is not decisive, as there are many cases, in which someone other than the owner has been held to be the keeper. ${ }^{77}$ Paragraph 1, article 5:101 of the Principles of European Tort Law also suggests the distinction between the 'keeper' who does not necessarily is an owner, and 'owner', who does not necessarily is the 'keeper'. This provision speaks about "a person who carries on an abnormally dangerous activity". Therefore, it places a greater emphasis upon the fact of who has performed particular activity rather than who is the owner of the object used to perform the abnormally dangerous activity. Such interpretation is supported also by point a), paragraph 2, article 1:101 of the Principles of European Tort Law, providing that "damage may be attributed in particular to the person [..] whose abnormally dangerous activity has caused it", accentuating the question of who has actually performed the abnormally dangerous activity. The Soviet era Latvian legal scholar Professor Jānis Vèbers has noted that liability for the damage caused by abnormally dangerous activity shall be applied, taking into account who has operated the abnormally dangerous activity. For instance, if the owner has transferred the particular object to another person, who can exploit this object or carry out some activity with this object, this other person, not the owner, shall be held liable, if abnormally dangerous activity will cause damage. ${ }^{78}$ It means that the actual carrying out of abnormally dangerous activity, instead of the title or other rights to the object that is involved in abnormally dangerous activity, is the decisive factor in determining the liable person. Contemporary Latvian legal scholar Professor Kalvis Torgāns indicates that the legislator wishes to attribute the liability for the damage caused by the person whose abnormally dangerous activity has caused the damage. ${ }^{79}$ Therefore, he also places the main emphasis on the question, who performs the abnormally dangerous activity, rather than who has title or other rights to the object involved in the abnormally dangerous activity. As performing of the abnormally dangerous activity usually involves possession of the object of abnormally dangerous activity, paragraph 2, article 2347 of the Civil Law of the Republic of Latvia strongly underscores the actual possession of this object with a reference not only to the owner (who will not always be the possessor of the said object), but also to the keeper, custodian or user of the said object. Moreover, if the legitimate possessor has lost the possession over the said object without his fault, the liability for potential damages, caused by abnormally dangerous activity, also transfers to the actual possessor of the said object.

The previous section of paper gave the opinion that the model of liability stipulated in article IV, Vienna Convention on Civil Liability for Nuclear Damage, is actually just another example of strict liability instead of absolute or quasi-absolute liability. However, this liability is applied to the operator, who, pursuant to the definition given in point c), article I of Vienna Convention, with regard to a nuclear installation means the person designated or recognized by the installation state as

76 Bar, C. von. Principles of European Law on Non-Conractual Liability Arising out of Damage Caused to Another. Stämpfli, Bruylant, Sellier. European Law Publishers, 2009, p. 720.

77 Bar, C. von. The Common European Law of Torts. Vol. 2. Damage and Damages, Liability for and without Personal Misconduct, Causality and Defences. Oxford: Clarendon Press, 2000, p. 360.

78 Vēbers, J. Saistības no kaitējuma nodarīšanas [Obligations from Causing the Damage]. Rīga, 1969, p. 44.

79 Torgāns, K. Saistību tiesības. II daḷa. Mācību grāmata [Law of Obligations. Part II. A coursebook]. Rìga: Tiesu namu aǵentūra, 2008, pp. 282-283. 
the operator of that installation. Therefore, also for such operator the decisive aspect is operation with nuclear installation and thus exercising an abnormally dangerous activity, not the title or other rights to the installation.

Exercising the abnormally dangerous activity as the decisive factor may be linked to the following aspects. First of all, it is useful to remember the statement of Cees van Dam about blurred borders between fault liability and strict liability, which includes the elements of fault liability. ${ }^{80}$ This aspect could be found in attribution of liability for damages, caused by the abnormally dangerous activity. Via this attribution, the fault of keeper is to some degree presumed, because, as this person has directly carried out the relevant abnormally dangerous activity, it may be presumed that he or she has acted at least with negligence, if abnormally dangerous activity has caused damage. Secondly, although one of the decisive characteristics of abnormally dangerous activity is the inability to exclude risks even by exercising due care, the person who directly carries out the relevant abnormally dangerous activity, is in the best position in comparison with all the other persons in preventing at least those risks, which may be prevented. In this context, the ratio of holding the keeper liable may be compared with the ratio, why in Germany the liability for failure to maintain the building, which has collapsed and caused damage, is applied to the actual possessor of the particular building, not always an owner. For instance, this liability may also be applied to the person who takes over the maintenance of the building or a structure. Such allocation of liability is justified with better possibilities to avert the risks. ${ }^{81}$ Thirdly, legal doctrine pointedly emphasises that the liability should be distributed to the person, who benefits from the particular activity, which is not necessarily the owner of the object involved in this activity. For instance, as stated in legal doctrine, the owner of the building benefits from his building only when the construction process is finished. While construction is in progress, the construction company is the person, who benefits from it and, hence, shall be held liable, if particular construction process shall be treated as abnormally dangerous activity and if it has caused particular damage. ${ }^{82}$

Therefore, if the legislator has provided strict liability for damages caused by abnormally dangerous activity, the decisive factor in allocation of this strict liability is who should be considered as the 'keeper' of the object, with whom the abnormally dangerous activity has been performed, or, to be more precise, who has performed the actual abnormally dangerous activity.

\section{Summary}

The research reflected in the current paper has yielded the following most important aspects, as well as brought the following conclusions:

1. To grasp the essence of the concept of abnormally dangerous activities, it is crucial to take into account the historical context of the time and situation, when the said concept was developed - i.e., the time of great technical innovations and creation of various objects, whose operation brought numerous advantages along with risks not yet known and, hence, not entirely controllable.

80 Dam, C. von. European Tort Law. $2^{\text {nd }}$ edition. Oxford: Oxford University Press, 2013, p. 297.

81 Ibid., p. 466.

82 Bar, C. von. The Common European Law of Torts. Vol. 2. Damage and Damages, Liability for and without Personal Misconduct, Causality and Defences. Oxford: Clarendon Press, 2000, pp. 359-360. 
2. The most distinctive feature of abnormally dangerous activity is the impossibility to eliminate the relevant risks even with exercising of due care.

3. Abnormally dangerous activity is an activity, not an object (thing or substance), nor the sum of object and activity, because, basically, the performance of activity with the certain object, not the object itself is what may cause abnormal danger, which cannot be eliminated even with exercising of due care.

4. The fact that in some countries the legislator has decided to apply stricter or even strict liability to the damages relevant to certain objects does not prove that these objects should be treated as abnormally dangerous equally with abnormally dangerous activities. In fact, even with respect to these objects that the decisive moment for the liability with respect to these objects is activity (or the lack of necessary activity) performed with these objects.

5. Liability for damages caused by abnormally dangerous activities may be regulated either by special provisions of law, applicable to each certain activity, or/and by general provisions, applicable to all kinds of abnormally dangerous activities. However, several types of certain abnormally dangerous activities may have important particularities and special provisions might be more suitable for taking into account these particularities. Therefore, to extent possible, it is advisable to provide special legal provisions for each type of abnormally dangerous activity. General provisions should be provided and applied only for the cases and extent, not covered by special provisions.

6. Liability for the damages caused by abnormally dangerous activities usually is regulated by one from two following models - a strict liability or a stricter fault liability with increased standard of care, or shifted burden of proof. It is up to legislator of each country to decide which model will be applied in respective country.

7. The opinion that strict liability could be traced back to Roman law and lex Aquilia could not be supported. Even the commentaries provided by Roman lawyers, for instance, Celsus, suggests to examine separately the fault of each person, involved in causing the damage, and causality related to the fault of each particular person. Such approach, therefore, rather suggests application of fault liability than strict liability.

8. In order to provide better prospects for persons, which may be held liable for the damages caused by abnormally dangerous activities, to insure their liability, it is advisable to provide in law that, similarly to the approach taken by Germany, the strict liability is limited also with certain monetary amount, i.e., the person, who has suffered damages, may claim the compensation according to the rules of strict liability within the given limitation. If the claimant would like to claim the compensation in amount, exceeding the given limitation, such claim could be made on the basis of fault liability.

9. The mandatory insurance plays an important role in liability for the damages caused by abnormally dangerous activities, if strict liability is applied to these damages, because only the requirement of mandatory insurance, applicable to the potentially liable person, insures the persons, ensuring real prospects to receive the compensation of their damages. However, it does not mean, that the insurer has his own separate liability for these damages.

10. Liability of the operator of nuclear installation stipulated in Vienna convention on civil liability for nuclear damage is just another example of strict liability with limited defences, not an absolute or quasi-absolute liability. 
11. Within the present wording of paragraphs 1 and 2 of the article 2347 of the Civil Law of the Republic of Latvia, the Supreme Court of the Republic of Latvia has validly explained in its judgment from the $5^{\text {th }}$ of March, 2015 in case No. SKC-250/2015 C04327108 that strict liability is applicable only to pecuniary damages, caused by abnormally dangerous activity. If abnormally dangerous activity has also caused non-pecuniary damages, the injured person may claim these damages on the basis of fault liability.

12. If the liability for the damages caused by abnormally dangerous activities is regulated by general provisions via strict liability, such liability shall be applied to the person, who has directly carried out the activity which has caused the damage, because (a) it may be presumed that this person has acted at least with negligence, if abnormally dangerous activity has resulted in damage; (b) the person, who directly carries out the relevant abnormally dangerous activity is in the best position in comparison with all the other persons to prevent at least those risks, which may be prevented; (c) this person benefits from exercising the particular abnormally dangerous activity.

\section{Sources}

\section{Bibliography}

1. Bar, C. von. Gemeineuropäisches Deliktsrecht. Erster Band. Die Kernbereiche des Deliktsrechts, seine Angleichung in Europa und seine Einbettung in die Gesamtrechtsordnungen. München: C. H. Beck'sche Verlagsbuchhandlung, 1996.

2. Bar, C. von. The Common European Law of Torts. Vol. 1. The Core Areas of Tort Law, its Approximation in Europe, and its Accomodation in the Legal System. Oxford: Clarendon Press, 1998.

3. Bar, C. von. The Common European Law of Torts. Vol. 2. Damage and Damages, Liability for and without Personal Misconduct, Causality and Defences. Oxford: Clarendon Press, 2000.

4. Bar, C. von. Principles of European Law on Non-Contractual Liability Arising out of Damage Caused to Another. Stämpfli, Bruylant, Sellier. European Law Publishers, 2009.

5. Boston, G. W. Strict Liability for Abnormally Dangerous Activity: The Negligence Barrier. San Diego Law Review, 597, 1999.

6. Cobb, M. “The Wrong Approach at the Wrong Time?": Maine Adopts Strict Liability for Abnormally Dangerous Activities in Dyer v. Maine Drilling and Blasting, Inc. 63 Maine Law Review, No. 331, 2010.

7. Dam, C. van. European Tort Law. Oxford: Oxford University Press, 2007.

8. Dam, C. van. European Tort Law. $2^{\text {nd }}$ edition. Oxford: Oxford University Press, 2013.

9. Getzler, J. Richard Epstein, Strict Liability, and the History of Torts. Journal of Tort Law, Vol. 3, Issue 1, 2010, art. 3. Oxford: University of Oxford, 2010.

10. Giliker, P., Beckwith, S. Tort. $4^{\text {th }}$ edition. London: Thomson Reuters, Sweet \& Maxwell, 2011.

11. Kārkliňš, J. Stingrās atbildības izslēdzošie apstākḷi [Exceptions of Strict Liability]. In: Ārvalsts investīcijas: kad tiesības mijiedarbojas. Latvijas Universitātes 74. zinātniskās konferences rakstu krājums. Rīga: University of Latvia Press, 2016.

12. Kubilis, J. Atbildības par paaugstinātas bīstamības avota radītu kaitējumu problemātika un modernizācija [The current issues and modernisation of liability for damage caused by abnormally dangerous activity]. In: Tiesību efektīvas piemērošanas problemātika. Latvijas Universitātes 72. zinātniskās konferences rakstu krājums. Rīga: University of Latvia Press, 2014.

13. Kubilis, J. Latvijas deliktu tiesību modernizācijas galvenie virzieni. Promocijas darbs [Main issues regarding modernisation of tort law in Latvia. Doctoral thesis]. Riga: University of Latvia, 2016.

14. Markesinis, B. S., Unberath, H. The German Law of Torts. A Comparative Treatise. $4^{\text {th }}$ edition, Entirely Reversed and Updated. Oxford, Portland: Hart Publishing, 2002.

15. Raz, J. Responsibility and the Negligence standard. Oxford Journal of Legal Studies, Vol. 30, Issue 1, 01.03.2010.

16. Richard, A., Epstein, A. A Common Lawyer Looks at Constitutional Interpretation. 72 U.L.REV., 699, 704, 1992. 
17. Rosenberg, A. Strict Liability Imagining a Legal Framework for Autonomous Vehicles. Tulane Journal of Technology and Intellectual Property, Vol. 20, Fall 2017. Tulane University School of Law, 2017.

18. Sirks, A. J. B. The slave who was slain twice: causality and the lex Aquilia (Iulian. 86 dig. D. 9,2,51). The Legal History Review, 79, 2011. Brill Academic Publishers.

19. Skačkovs, D. Par civiltiesisko atbildību, kad zaudējumus nes paaugstinātas bīstamības avots [On civil liability, when the damages is caused by object of enormous danger]. Jurista Värds, No. 32(225), 2001. Available: www.juristavards.lv [last viewed 18.01.2018].

20. Torgāns, K. Saistību tiesības [Law of Obligations]. Part II. Rīga: Tiesu namu aǵentūra, 2008.

21. Torgāns, K., Kārkliņš, J., Bitāns, A. Lìgumu un deliktu problēmas Eiropas Savienībā un Latvijā [Issues of torts and contracts in EU and Latvia]. Rīga: Tiesu namu aǵentūra, 2017.

22. Vēbers, J. Saistības no kaitējuma nodarīšanas [Obligations from causing the damage]. Rīga, 1969.

\section{Normative Acts}

1. Vienna convention on civil liability for nuclear damage. Available: https:/www.iaea.org/sites/ default/files/infcirc500.pdf [last viewed 19.01.2018].

2. European Group on Tort Law. Principles of European Tort Law. Available: http://civil.udg.edu/php/ biblioteca/items/283/PETL.pdf [last viewed 19.01.2018].

3. Gesetz über die Eisenbahn-Unternehmugen vom 3 November 1838. Available: https://www.lwl.org/ westfaelische-geschichte/que/normal/que1030.pdf [last viewed 06.03.2019].

4. Latvijas Republikas Civillikums [Civil Law of the Republic of Latvia]. Ziņotājs, No. 1, 14.01.1993.

5. Estonian Law of Obligations Act. Available: https://www.riigiteataja.ee/en/eli/506112013011/ consolide [last viewed 06.03.2019].

6. European Parliament resolution with recommendations to the Commission on Civil Law Rules on Robotics (2015/2103(INL)); European Economic and Social Committee opinion on AI (INT/806-EESC-2016-05369-00- 00-AC-TRA). Available: http://www.europarl.europa.eu/sides/ getDoc.do?pubRef=-//EP//TEXT+TA+P8-TA-2017-0051+0+DOC+XML+V0//EN [last viewed 05.03.2019].

\section{Case Law}

1. Latvijas Republikas Augstākās tiesas Civillietu departamenta 2015. gada 5. marta spriedums lietā Nr. SKC-250/2015 C04327108 [Judgment of the Civil Department of the Supreme Court of the Republic of Latvia in case No. SKC-250/2015 C04327108 from 5 March, 2015]. Not published.

2. Latvijas Republikas Augstākās tiesas Civillietu departamenta 2016. gada 3. jūnija spriedums lietā Nr. SKC-143/2016 C28244808 [Judgment of the Civil Department of the Supreme Court of the Republic of Latvia in case No. SKC-143/2016 C28244808 from 3 June, 2016]. Not published.

\section{Other Sources}

1. Communication from the European Commission to the European Parliament, the European Council, the Council, the European Economic and Social Committee and the Committee of the Regions. Artificial Intelligence for Europe. Available: https:/ec.europa.eu/digital-single-market/en/ news/communication-artificial-intelligence-europe [last viewed 06.03.2019].

2. A Common EU Approach to Liability Rules and Insurance for Connected and Autonomous Vehicles. European Added Value Assessment. Accompanying the European Parliament's Legislative Own-Initiative Report. (Rapporteur: Mady Delvaux). Study. EPRS/European Parliamentary Research Service. February 2018. Available: http://www.europarl.europa.eu/RegData/etudes/ STUD/2018/615635/EPRS_STU(2018)615635_EN.pdf [last viewed 06.03.2019].

3. Academic Dictionaries and Encyclopedias. Available: http://www.enacademic.com/ [last viewed 19.01.2018].

4. BRANCH: Britain, Represantation and Nineteenth - Century History. Available: http://www. branchcollective.org/ [last viewed 19.01.2018].

5. Chemistry Explained. Available: http://www.chemistryexplained.com/ [last viewed 20.01.2018].

6. Encyclopaedia Britannica. Available: https://www.britannica.com/[last viewed 20.01.2018].

7. Lenntech. Available: https://www.lenntech.com/ [last viewed 21.01.2018].

8. Scotland National Mining Museum. Available: https://nationalminingmuseum.com/ [last viewed 21.01.2018].

9. The Independent. Available: www.independent.co.uk [last viewed 19.01.2018]. 
Publisher: University of Latvia Press

Aspazijas bulvāris 5, Riga, LV-1050

www.apgads.lu.lv

apgads@lu.lv 


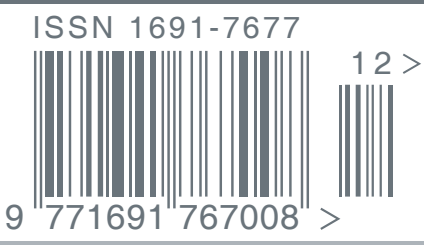

Kalvis Torgāns. Contribution of Faculty of Law, University of Latvia, to Science, State, and Nation

Irene Kull, Laura Kask. Electronic Signature Under the eIDAS Regulation in Domestic and Cross-Border Communication: Estonian Example

Ārija Meikališa, Kristine Strada-Rozenberga. Impact of Directives of European Parliament and of Council on Development of Latvian Criminal Procedure Law: General Overview and Procedural Protection of Victims with Specific Protection Needs

Anna Rytel-Warzocha, Andrzej Szmyt. Current Constitutional Changes in Poland Against the Background of Polish Political and Legal Traditions

Jānis Lazdiņ̌̌, Kärlis Ketners. Avoidance of Double Taxation in the Area of Income Tax in Latvia

Thomas Schmitz, Yogyakarta. Political Parties and Their Funding in Germany

Sanita Osipova. "The Political Platform of the Latvian People's Council" of 17 November 1918 as the Founder of the Gender Equality Tradition in Latvia Within the Discourse of European Ideas on Gender Equality

Jautrite Briede. Content and Application of Duty of Care Principle in the Field of Administrative Law in Latvia

Jānis Rozenfelds. Collateral in Public Register as a Security of Private Debt

Kaspars Balodis, Arta Snipe. Origins of Separated Ownership and Possible Solutions for Unifying Thereof

Silvia Kaugia. Legislative Intent of Act in Estonia

Edvins Danovskis. Implementation of the Concept of 'Public Assets' in the Latvian Legal System

Lauris Rasnačs. Regimes of Liability for Damages Caused by Abnormally Dangerous Activities 